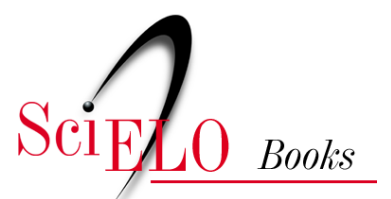

\title{
A democracia inconclusa um estudo da reforma sanitária brasileira
}

\author{
Silvia Gerschman
}

GERSCHMAN, S. A democracia inconclusa: um estudo da reforma sanitária brasileira [online]. 2nd ed. Rio de Janeiro: Editora FIOCRUZ, 2004, 270 p. ISBN: 978-85-7541-537-5.

https://doi.org/10.7476/9788575415375.

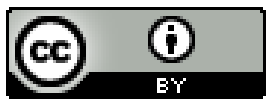

All the contents of this work, except where otherwise noted, is licensed under a Creative Commons Attribution 4.0 International license.

Todo o conteúdo deste trabalho, exceto quando houver ressalva, é publicado sob a licença Creative Commons Atribição 4.0. 


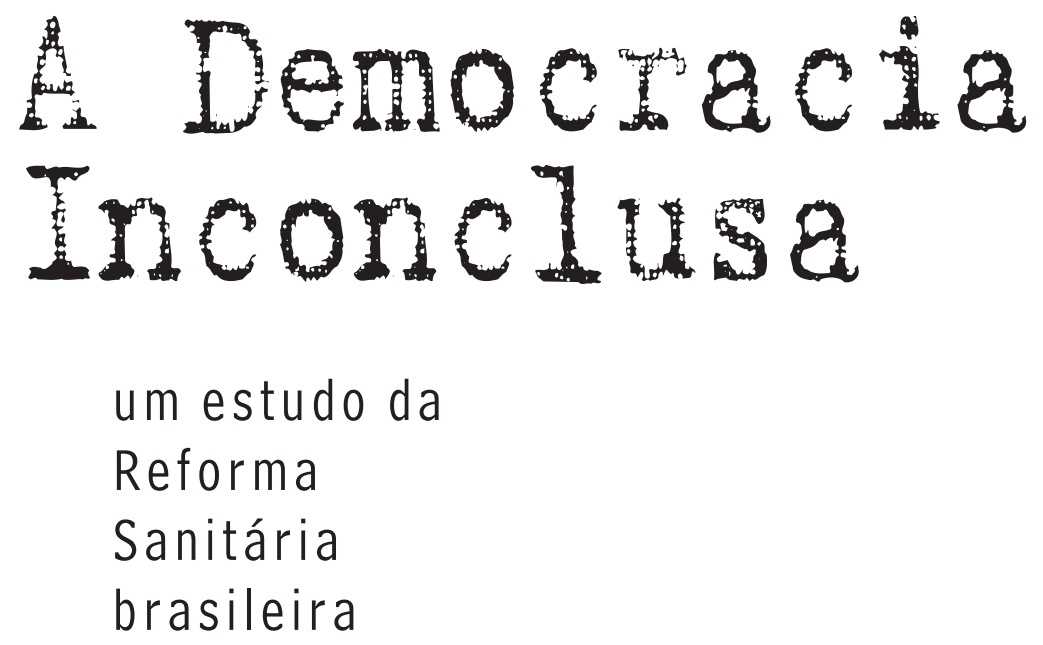




\section{FUNDAÇÃO OSWALDO CRUZ}

Presidente

Paulo Ernani Gadelha Vieira

Vice-Presidente de Ensino, Informação e Comunicação

Nísia Trindade Lima

\section{EDITORA FIOCRUZ}

Diretora

Nísia Trindade Lima

Editor Executivo

João Carlos Canossa Mendes

Editores Científicos

Gilberto Hochman

Ricardo Ventura Santos

Conselho Editorial

Ana Lúcia Teles Rabello

Armando de Oliveira Schubach

Carlos E. A. Coimbra Jr.

Gerson Oliveira Penna

Joseli Lannes Vieira

Ligia Vieira da Silva

Maria Cecília de Souza Minayo 
Silvia Gerschman

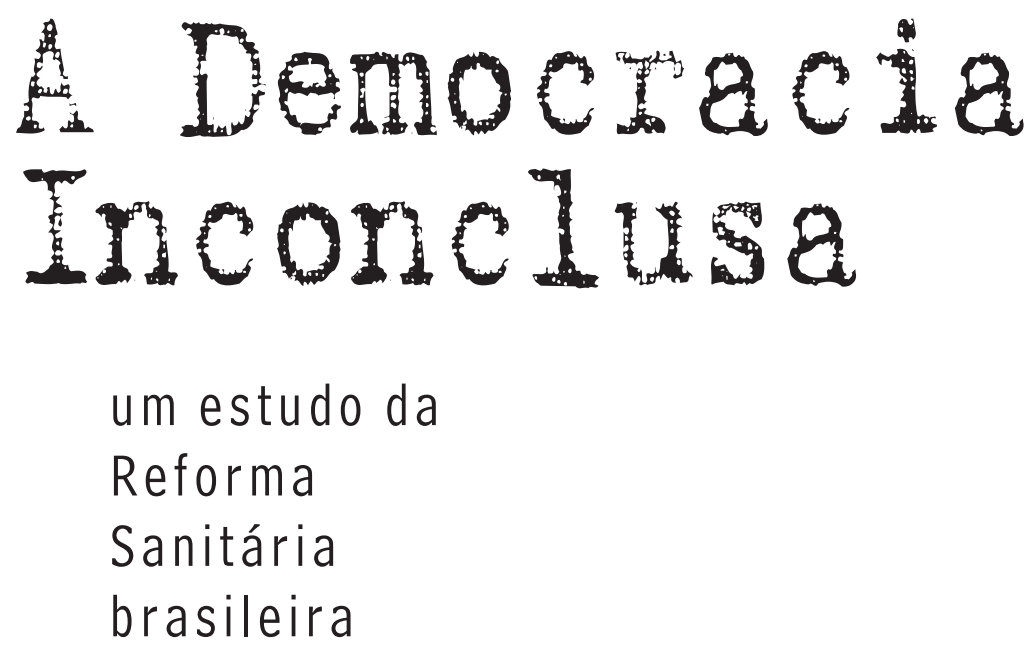

2ª edição

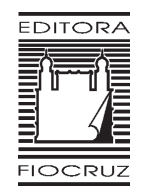


Copyright (C) 2004 da autora

Todos os direitos desta edição reservados à

FUNDAÇÃO OSWALDO CRUZ / EDITORA

ISBN: 85-85676-20-5

$1^{\text {a }}$ Reimpressão: 2011

Colaboraram na $2^{\mathrm{a}}$ edição:

Capa, Projeto Gráfico e Editoração Eletrônica: Carlota Rios

Imagem da capa: Blue \#3 de Georgia O’Keeffe, 1916 (The Brooklyn Museum, N. York)

Revisão e copidesque: Marcionílio Cavalcanti de Paiva

Digitação: Gislene Monteiro Coimbra

Catalogação na fonte

Centro de Informação Científica e Tecnológica

Biblioteca da Escola Nacional de Saúde Pública Sergio Arouca

G381d Gerschman, Silvia

A Democracia lnconclusa: um estudo da Reforma Sanitária brasileira/

Silvia Gerschman. 2. ed. Rio de Janeiro: Fiocruz, 2004.

$272 \mathrm{p}$.

1. Refoma Sanitária - Brasil. 2. Política de Saúde - Brasil

CDD-20. ed. -362. 10680981

2011

EDITORA FIOCRUZ

Av. Brasil, 4036 - Térreo - sala 112 - Manguinhos

21041-361 - Rio de Janeiro - RJ

Tels: (21) 3882-9039 / 3882-9041

Telefax: (21) 3882-9006

http:/ /www.fiocruz.br

e-mail: editora@fiocruz.br

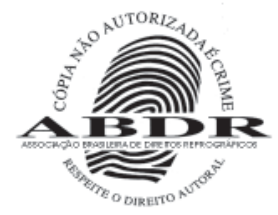


À minha filha Mariana, companbeira de todas as jornadas. 


\section{Sumário}

PREFÁCIO 9

ApresentaÇÃo 13

\section{Parte I}

1. A Construção da Democracia: algumas questões históricas e teóricas 29

2. O Processo de Reformulação do Setor Saúde: os atores, as estratégias e o papel dos organismos estatais 53

3. Os Movimentos Sociais em Saúde: questões teóricometodológicas para sua abordagem 67

\section{PARTE II}

4. O Movimento Popular em Saúde 89

5. O Movimento Médico: composição e trajetória 135

\section{Parte III}

6. O Processo de Implementação da Reforma Sanitária 179

7. A Descentralização do Sistema de Saúde 237

8. Os Conselhos de Saúde 237

Conclusão 249

ReFERÊNCIAS BibliográFicAS 265 


\section{Prefácio}

É relativamente recente o estudo explícito e sistemático da democratização, ou seja, dos processos pelos quais os regimes políticos transitam de diferentes formas de autocracia e tentam consolidar algum tipo de democracia. Tal estudo foi muito estimulado pelo grande número de mudanças de regime ocorridas desde 1974, quando Portugal foi o primeiro a derrubar sua prolongada ditadura. Nas duas décadas e meia seguintes, quase 50 países seguiram esse caminho. Não há um só continente que não tenha sido afetado por essa onda de democratização e há poucas autocracias remanescentes que de alguma forma não foram por ela ameaçadas.

A ditadura militar que governou o Brasil a partir de 1964 foi uma das primeiras da América Latina a mostrar algum sinal de desejo de pelo menos liberalizar suas instituições e práticas. Já em 1979 o novo Presidente do País, general João Baptista de Oliveira Figueiredo, tinha a intenção de apoiar uma abertura na vida política brasileira, com o propósito - não acompanhado, porém, de um calendário específico - de fazer com que o Brasil retornasse à democracia.

Esse retrospecto revela que a transição brasileira foi uma das mais proteladas e controladas. Passaram-se mais de dez anos até que um chefe do Executivo popularmente responsável assumisse o poder e a perspectiva de uma retomada do poder ditatorial declinasse significativamente. Durante todo esse período, os militares e seus aliados civis permaneceram firmemente no poder e controlaram intimamente tanto o ritmo quanto o conteúdo das formas políticas.

A abertura permitiu uma substancial mobilização da sociedade civil, e isso, sem dúvida, teve algum impacto sobre a decisão final de se aceitarem práticas democráticas. Não obstante, a grande campanha popular para a realização de eleições diretas para a Presidência, em 1985, foi facilmente suprimida. Sobre 
isso, não há provas de que os governantes militares brasileiros tenham sido compelidos a fazer concessões explícitas, muito menos a se engajarem em pactos com elementos de oposição.

Isso contrasta fortemente com o caso da Argentina - onde a derrota na Guerra das Malvinas conduziu a um rápido e incontrolável colapso do ancien régime - e com o do Uruguai e do Chile - onde derrotas não previstas em plebiscitos forçaram os ditadores militares a negociar uma retirada do poder com os partidos de oposição.

Tudo isso torna a pesquisa de Silvia Gerschman mais desafiadora. No caso do Brasil, o processo contemporâneo de democratização foi incomumente gradual e parcial. Não houve momentos definitivos ou períodos concentrados de ruptura com a autocracia anterior. Instituições e práticas - assim como as relações de poder que as cercam - mudaram apenas perifericamente em ritmos muito diferentes entre si. O tema de sua escolha - política de saúde - não foi particularmente destacado dentro do processo global de democratização, embora tenha sido afetado em grande parte, de modo indireto, pelas transformações que se evidenciaram nas eleições, nos partidos políticos, na liberdade de associação, na elaboração da Constituição e na responsabilidade (accountability) das ações do Executivo.

Contudo, em pelo menos três aspectos a autora foi além dos limites usuais do que ficou conhecido como 'transitologia' e 'consolidologia':

- pesquisou profundamente numa arena essencial e específica - a política de saúde - quando virtualmente toda a literatura existente sobre democratização concentrava-se exclusivamente em temas referentes a procedimentos e escolhas institucionais que - supostamente - afetam todas as arenas da política;

- desviou o foco de atenção de uma preocupação exclusiva com mudanças em nível nacional para o impacto dessas mudanças sobre grupos profissionais específicos sobre unidades territoriais nacionais, isto é, sobre o 'Movimento Médico’ e sobre alguns municípios distribuídos pelo Brasil;

- forçou os analistas da transição e consolidação a dar atenção não apenas à tomada de grandes decisões de política, mas também à sua implementação em setores e locais específicos, também chamando atenção para as mudanças de micro e médio níveis necessárias para tornar a democratização efetiva para os cidadãos. 
O produto final é uma importante contribuição para a compreensão não apenas da substância da transição particularmente prolongada e controlada no Brasil, mas também do processo pelo qual a democratização pode ter impacto sobre específico setor da política e afetar a vida diária dos cidadãos numa ampla gama de países. Silvia reuniu três níveis cruciais de análise para sustentar a explanação de um processo político-social complexo: o nível de democratização do regime; o nível intermediário de atores coletivos e dos movimentos sociais; e o nível diferenciado de uma área de política com implicações de longo prazo para a estabilidade de uma política democrática, de um economia produtiva e de uma sociedade justa, ou seja, a saúde de sua população. Infelizmente, que eu conheça, não há estudos comparáveis sobre quaisquer dos cerca de 50 países que tentaram mudanças de regime dessa ordem.

Nós, em Stanford, tivemos o privilégio de ter Silvia Gerschman conosco por um longo período como pesquisadora convidada. Aqui e ali, em sua análise, pode-se sentir o impacto de sua estada em nossa companhia. Em várias ocasiões, em palestras, conferências e seminários, Silvia discutiu seu projeto com outros pesquisadores do Centro de Estudos Latino-Americanos (The Center for Latin American Studies - CLAS) e também nos influenciou por suas idéias e pelo seu entusiasmo. Pessoalmente, fiquei especialmente impressionado com o modo pelo qual conseguiu expIorar minha noção de 'regimes parciais' e aplicá-la de forma criativa ao setor de política de saúde em sua conclusão.

O substancial de seu esforço, porém, foi realizado no Brasil - num difícil processo de pesquisa de campo. Reuniu dados primários de uma variedade de fontes documentais; realizou entrevistas com atores relevantes e, ainda, reconstituiu uma história complexa a partir de elementos em diversos níveis de agregação no transcorrer de um longo período. O tempo despendido em Stanford foi construtivamente gasto num esforço de colocar seu estudo de caso num contexto teórico e comparativo mais amplo, mas o trabalho realmente difícil dependeu de uma sistemática e longa compilação anterior de dados relevantes e precisos.

O que a autora descreve como o 'caminho das pedras' não teve início nas reuniões em minha sala; começou muito antes, nos arquivos e gabinetes de muitas instituições brasileiras públicas e privadas. Como alguém que, há muito anos, passou pela mesma experiência de pesquisa de campo, posso testemunhar pessoalmente quão frustrante e excitante pode ser reunir dados originais no Brasil. Há poucos países no mundo onde tão pouco está à disposição dos pesquisadores para a compreensão de processos políticos e sociais e onde tanto 
pode ser conseguido com a ajuda dos atores políticos e sociais envolvidos nestes. Silvia Gerschman sentiu e explorou esse paradoxo e todos nós temos essa dívida com ela.

Philippe C. Schmitter

Universidade de Stanford 


\title{
Apresentação
}

\begin{abstract}
A versão original do livro foi resultado de uma reflexão marcada pela conjuntura política de fins da década de 80 e início da de 90. A rapidez das mudanças globais após a primeira metade da década de 90 , porém, requer uma contextualização que permita retomar as questões e desafios que a reformulação da política de saúde trouxe ao cenário da democracia brasileira. Os dez anos que nos encaminharam ao 'pulo' do próximo século falam de um mundo em acelerada e vertiginosa transformação em todos os campos da realidade e do que fazer humano; esse clima e essa sensação do fugaz marcam a apresentação da reedição de $A$ Democracia Inconclusa.
\end{abstract}

No novo milênio, a democracia está fortemente ameaçada. Nos países de industrialização avançada, o Welfare State vem atravessando uma longa crise que já leva quase 20 anos, alimentada, na década de 90 , pelo processo de globalização da economia: predominância do mercado face ao Estado, profundas mudanças no mundo do trabalho e fortes tendências à concentração econômica movida pelo capital financeiro, que se tornou o eixo do processo de acumulação capitalista (Gerschman \& Vianna, 1997).

As políticas sociais dos Estados democráticos, após a Segunda Guerra, passaram a ser centrais na atividade política e econômica desses países. A busca de um maior bem-estar e igualdade constituiu-se em mecanismo central de uma política econômica que sofreu, nos anos 90, um forte retrocesso. As democracias avançadas passaram a sacrificar a política econômica que marcou o Estado keynesiano, restringindo e monetarizando benefícios que sob o Welfare State eram usufruídos claramente como uma condição do exercício do direito de cidadania. Cabe ressaltar que uma parte importante da bibliografia que nos últimos anos vem discutindo o caráter da crise (Vianna, 1998; King, 1988; Pierson, 1994) destaca que, embora as bases sobre as quais se estabeleceu o Welfare - 
uma forte classe operária organizada e demandante - tenham sido afetadas com o desemprego e a flexibilização dos contratos de trabalho, esse enfraquecimento não foi suficiente para permitir o desmonte dos Welfare States europeus.

Assim, acredita-se que seja mais adequado se referir à crise como processo de profundas mudanças nos Estados de bem-estar europeus através da readequação dos gastos do Estado e de um maior controle sobre benefícios. Esse processo afetou, com mais intensidade, os importantes contingentes de imigrantes dos países pobres que chegaram sem nenhum tipo de proteção social, sem condições de serem absorvidos por um mercado de trabalho em franco retrocesso nos países ricos, e, portanto, não incorporados ao sistema de seguridade social. Mudou, assim, a geografia humana desses países, tornando as desigualdades sociais um problema que se acreditava erradicado sob o predomínio do Estado keynesiano, que aproxima de maneira tortuosa os países ricos dos pobres.

Com o Estado neoliberal, a democracia se tornou tão errática quanto as restantes produções da era da globalização: as guerras, a perda dos valores relacionados à existência humana, a degradação ética, a devastação da natureza no planeta, a falta de comunicação humana globalizada. No que se refere à democracia, a volatilidade diz respeito a alguma condição ou conjunto de condições que, de uma parte, fogem das mãos dos governantes, na medida em que as políticas econômicas são as mesmas para todos os países e, de outra, da própria sociedade, já que a capacidade que esta tem de influenciar os governos eleitos é quase nula (Maier, 1994). Assim, cada vez mais a democracia é esvaziada de representatividade, dado o abismo existente entre cidadãos e governo, sendo a resposta da sociedade o desinteresse e a perda de confiança na democracia, nos partidos e, mais do que tudo, nos políticos.

$\mathrm{Na}$ América Latina e no Brasil, que atravessaram longos períodos autoritários, o desempenho das democracias, na década de 90, tem deixado um forte ranço de ineficiência e corrupção no exercício dos cargos públicos e também profundas desigualdades sociais relacionadas aos cortes importantes em políticas sociais. Os comportamentos políticos já mencionados marcaram também as 'novas democracias', contribuindo para um sintomático crescimento dos votos nulos e em branco e, conseqüentemente, para um notável esvaziamento eleitoral.

Nesses países hoje chamados pobres, ou se poderia dizer, submersos em processos de busca 'permanente' de um desenvolvimento industrial que não chega de maneira plena, a década de 80 representou, em particular para o Brasil, uma época de esperanças. A transição à democracia foi depositária de novas 
perspectivas de crescimento econômico com justiça social que acompanhariam a cena política democrática aproximando, finalmente, a América Latina das social-democracias européias.

Foi o que ocorreu em relação à política de saúde, em especial, por ter sido a Reforma Sanitária fundada no direito universal à saúde e incorporada à Constituição de 1988. Mesmo com o retrocesso sofrido pelas políticas sociais, essa particular política social permaneceu na agenda dos governos. O processo foi extensamente analisado em $A$ Democracia Inconclusa, através do estudo da transição à democracia no Brasil, das bases sociais de apoio à Reforma Sanitária, das mudanças organizacionais que se operaram nas instituições estatais de saúde e do processo de descentralização, eixo central na implementação das mudanças políticas do setor.

Assim, os projetos de políticas sociais montados no final dos anos 80 , especialmente no setor da saúde, apoiados na noção de direito universal, tiveram na década de 90 um cenário de implementação profundamente adverso. A democracia durante esse período sofreu importantes abalos, também tratados no livro. No que se refere ao primeiro governo eleito democraticamente, observou-se que o andamento na implementação da política de saúde atravessou dilações, empecilhos e alterações dos princípios constitucionais relativos ao setor.

No início do novo século, com a continuidade das políticas neoliberais, constatam-se resultados funestos em termos de aumento da pobreza, da violência urbana, da criminalidade ligada ao tráfico de drogas, da extensão da repressão às populações periféricas das cidades e da população presidiária, paralelamente ao crescimento da corrupção nas forças policiais e nas altas esferas do governo. A saúde da população viu-se afetada negativamente, mais fortemente nos estratos de baixa renda, reaparecendo doenças tais como o dengue, tratada aqui como uma epidemia que assolou o estado do Rio de Janeiro em 1992 e que ressurgiu em 2002, portanto dez anos depois, na sua forma mais virulenta, a hemorrágica.

Ainda que com esses traços catastróficos que impregnaram a democracia como sistema político e as políticas sociais como alternativa fundante de uma sociedade mais eqüitativa, interessa localizar como tem evoluído, especificamente, a política de saúde, de maneira a desenhar a presença ou não de continuidade entre ambas conjunturas, a que se estende do final dos anos 80 até metade dos 90 , analisada em profundidade no livro, e a que se estende do final dos 90 à entrada no novo século. 
Gostaríamos de ressaltar duas questões em relação ao período atual. De uma parte, aspectos que falam de uma continuidade em relação ao período anterior no que se relaciona à definição da política de saúde. Trata-se, basicamente, do processo de descentralização e do forte teor político regulatório do Estado em sua implementação. A outra questão diz respeito à permanência no cenário político de atores sociais constituintes e constitutivos da política de saúde na conjuntura tratada no livro.

Os municípios têm registrado, nos últimos anos da década passada e nos primeiros do novo século, uma alta adesão à municipalização da política de saúde. Tal fato pode ser constatado a partir do alto número de municípios no País que têm se candidatado a se habilitar aos modelos de gestão plena de atenção básica e de sistemas de saúde e, recentemente, à Norma Operacional de Assistência à Saúde. Esta última enquadra os municípios em um processo de integração via territorialização dos mesmos na assistência à saúde.

Mas essa adesão é marcada por um processo burocrático no qual o município se candidata à habilitação sem por vezes efetivamente estar implementando os requisitos exigidos para declará-lo habilitado no modelo de gestão em questão. Além disso, a habilitação, de fato, significa o acesso a um financiamento federal que não seria obtido sem a declaração municipal do cumprimento de tais requisitos. Ou seja, a adesão está relacionada à captura municipal de recursos federais.

Ainda que durante os últimos anos não tenha havido reformulações significativas do SUS, as Normas Operacionais Básicas, instrumentos de regulação política do setor, ao mesmo tempo que favoreceram a descentralização do sistema de saúde trouxeram algumas alterações relacionadas ao modelo de assistência à saúde. A mudança mais importante incorporada ao sistema foi a definição de programas de atenção básica como uma maneira de cobrir assistencialmente os setores da população mais desassistidos, ou de baixo acesso, que correspondem a altos níveis de pobreza e/ou border line da pobreza absoluta. Referimo-nos especialmente ao Programa de Saúde da Família, que passou a ser o 'carro chefe' do Sistema Único de Saúde, com todas as dificuldades que se observam na promoção de uma medicina integrada nos níveis diferenciados de complexidade.

De fato, isso gerou uma extensa polêmica no setor, relacionada à efetivação de políticas focalizadas e serviços simplificados para a atenção de grupos populacionais extremamente pobres, e a conseqüente exclusão das classes médias do sistema. Tais mudanças levariam à perda do caráter universal do sistema de saúde, ao desinvestimento em recursos humanos, instalações, equipamentos 
e preservação do parque hospitalar do País paralelo ao crescimento do seguro privado entre as classes médias.

Alternativamente, há quem pense que se trataria de políticas complementares, que, ao contrário de promover a quebra da cobertura universal à saúde, possibilitariam a complementaridade da atenção, sem diminuir a qualidade, basicamente por adaptar a assistência sanitária ao risco de extensão de doenças para populações extremamente pobres. Dessa maneira, o conflito universalização/ focalização permanece sem elucidação até os dias de hoje e continua a ser um divisor de águas nas instâncias governamentais do sistema e nas organizações da sociedade que têm participação na deliberação da política de saúde.

Quanto à participação dos atores sociais, podemos dizer que os Conselhos de Saúde, em que, como foi observado na primeira edição do livro, têm importante assento, por definição constitucional, as organizações/agrupamentos da sociedade, já nasceram carentes para o exercício da função de representação, tão carentes quanto as camadas sociais que lhes dão voz e voto. Dados de pesquisa recente $^{1}$ evidenciam que os Conselhos de Saúde locais são como que convidados 'inconvenientes' ao exercício do processo decisório. Sua base de representação é frágil e a formação dos conselheiros é insuficiente para a tomada de decisões em assuntos de caráter técnico. Cabe lembrar que os Conselhos, originariamente compostos por organismos comunitários, hoje são mais um espaço de representação corporativa, em que organismos de representação de usuários portadores de doenças - deficientes físicos, portadores de HIV, renais crônicos etc. - atuam junto a representantes dos profissionais de saúde, do setor filantrópico e dos órgãos governamentais.

Isso facilita que nas reuniões dos Conselhos se discutam prioritariamente as questões colocadas pelos representantes das Secretarias Municipais de Saúde, que, por sua vez, apresentam pacotes previamente definidos pelas instâncias intergestoras - tripartite e bipartite ${ }^{2}$ - e pelo Ministério de Saúde de forma direta.

\footnotetext{
Avaliação, Análise e Integração de Programas e Experiências Inovadoras de Políticas de Saúde e Políticas Sociais (dados atualizados em 2002). Coordenação: Silvia Gerschman. Professora associada: Maria Lucia Werneck Viana.

2 A comissão intergestora tripartite é de âmbito nacional, tem caráter paritário e nela estão representados o Ministério da Saúde, o Conselho Nacional de Secretários Estaduais de Saúde (Conass) e o Conselho Nacional de Secretários Municipais de Saúde (Conasems). Sua função é assistir ao Ministério da Saúde na implantação e operacionalização do SUS, devendo se submeter ao poder deliberativo e fiscalizador do Conselho Nacional de Saúde. Já as comissões bipartites de âmbito estadual são formadas paritariamente por dirigentes da Secretaria Estadual e órgãos de representação dos Secretários Municipais do Estado (Cosems). Nessas comissões são decididos os aspectos operacionais do SUS (Manual do Gestor do SUS, publicado pelo Cosems-RJ, em março de 1997).
} 
Uma vez formulados e discutidos, esses programas passam pelo Conselho Municipal de Saúde, onde os representantes disputam benefícios específicos, operando-se assim a primeira adaptação dos programas de atenção básica ao contexto municipal.

Cabe acrescentar que, nessa modalidade, os Conselhos têm um papel contraditório: juridicamente são órgãos deliberativos, mas, de fato, dão andamento a políticas adotadas alhures, nos âmbitos específicos das três instâncias governamentais - federal, estadual e municipal - processadas nas Comissões Intergestoras. Esse procedimento atualiza de maneira permanente o conflito latente dos pesos desiguais entre burocracias políticas, profissionais de saúde e organismos de representação da sociedade e usuários.

$\mathrm{Na}$ atual conjuntura histórica de ajuste permanente e no contexto latinoamericano de restrições à soberania nacional - ocasionadas por governos que chegam ao poder via partidos social-democratas, mas que implementam as políticas da 'nova direita' que Maier (1994) denominou de retro-right - a representação política se esvazia e os direitos sociais universais se tornam um bem social difuso, ainda que sancionados constitucionalmente como no Brasil.

$\mathrm{Na}$ falta de uma experiência histórica sustentada na mobilização e organização sociopolítica da sociedade, os conselhos locais de saúde, ainda que possuam uma existência legítima, carecem dos instrumentos políticos e técnicos capazes de transformar a lei em princípios executáveis para a viabilização de demandas sociais. Assim, no embate das forças políticas e/ou grupos de interesse, é grande o predomínio das burocracias técnico-políticas no processo decisório.

O processo de descentralização, no fim da década passada e início deste novo século, revela a abrangência de situações e processos relacionados a inovações na gestão da saúde municipal. Os resultados são extremamente contraditórios. Em alguns municípios, o tipo de inovação gerencial incorporada representa um claro avanço no processo de descentralização e implementação do SUS, através de iniciativas da própria gestão municipal, que vão além das diretrizes federais/estaduais, injetando recursos orçamentários próprios na implementação da política de saúde. Em outros, observa-se a implantação de programas e experiências formuladas exclusivamente no nível federal/estadual - que são incorporadas pela gestão municipal como uma maneira de receber recursos externos (principalmente do nível federal) - ou modalidades de gestão de recursos humanos, como no caso das cooperativas médicas que, de fato, inovam nas relações de trabalho mas descomprometem o governo municipal da responsa- 
bilidade, historicamente legitimada pelo Estado, pela existência de relações trabalhistas sustentadas na estabilidade contratual e em encargos sociais - aposentadoria, férias, décimo terceiro salário etc. -, a cargo do empregador.

Para os profissionais de saúde, em sua maioria médicos, o comprometimento com o SUS e o processo de descentralização é atrelado a condições de trabalho, oportunidades de formação, processo de trabalho e remuneração alcançada no setor. Mas pouca tem sido a preocupação das instâncias de governo local em criar mecanismos que incorporem os profissionais com base em pressupostos de responsabilidade social e compromisso político com o aperfeiçoamento dos serviços enquanto centrais para o bom desempenho do sistema de saúde municipal.

Os médicos agem sob a pressão do exercício permanente de atenção médica aos pacientes e isto os libera de quaisquer responsabilidade de outra natureza. Os gestores do sistema municipal agem sob a pressão política do governo municipal e, ainda que na sua maioria sejam profissionais médicos, esquecem que não há lugar para um sistema de saúde eficaz sem que seus elementos constitutivos - recursos humanos, equipamentos, infra-estrutura dos serviços e demandas sociais - estejam permanentemente no centro das preocupações e do investimento do governo local, o que, de fato, implica profundas mudanças no processo decisório no setor da saúde.

O objeto deste trabalho é o estudo dos movimentos sociais em saúde ligados ao processo de formulação e de implantação das políticas de saúde no período que se estende de meados da década de 70 a 1994. O estudo desse período relaciona-se à possibilidade de pensar as políticas de saúde no Brasil à época da transição à democracia e da consolidação democrática, sob uma perspectiva que não se sustenta exclusivamente no Estado como o locus privilegiado dos processos de formulação e implementação das políticas sociais.

$\mathrm{Na}$ escolha do objeto de investigação, consideramos central a questão do Movimento Popular em Saúde e do Movimento Médico - no processo de formulação e implementação das políticas de saúde na transição à democracia -, por avaliarmos que estes configuram o Movimento Social em Saúde. Embora tenha sido considerado ao longo deste trabalho, excluímos o autodenominado Movimento Sanitário ${ }^{3}$ - ainda que também integrasse o Movimento em Saúde -,

\footnotetext{
A exclusão deve-se ao fato de a questão do Movimento Sanitário ter sido objeto específico da análise de outros estudos no setor, dentre eles, o de Escorel (1987).
} 
por se tratar de um grupo restrito e diferenciado de origem acadêmica e que constitui, em si mesmo, tema de investigação.

Interessávamo-nos examinar mais profundamente o papel exercido por tais movimentos no processo de transformação da política de saúde no Brasil que culminou com a denominada Reforma Sanitária Brasileira - e as mudanças observadas na atuação do Movimento Popular em Saúde e do Movimento Médico, no difícil percurso da implantação do mesmo, a partir de 1986 e em pleno processo de consolidação da democracia.

O que torna a implementação da política de saúde uma questão de difícil solução? Como se combinam atores, arenas e circunstâncias políticas? Qual o papel do Estado? E qual o papel dos movimentos sociais em saúde nos dois momentos da política de saúde? Como os usuários se fazem representar perante a política de saúde? Quais os partidos, as associações e os movimentos que interagem na implantação, diferentemente da formulação, da política de saúde? Tais questões nortearam o desenvolvimento deste estudo.

Nosso argumento central é que os atores sociais interagiram em um campo não conflitivo no processo de formulação da política, enquanto a diversidade de interesses do próprio Movimento Social em Saúde estava diluída na oposição em bloco ao regime autoritário.

A partir do momento em que a reformulação da política de saúde foi sancionada na Constituição Nacional, já no processo de construção democrática, sua implementação passou necessariamente pela criação de um campo específico de mediação entre a esfera governamental e a esfera social. Assim, a recomposição das relações Estado/Sociedade, que haviam sido parcialmente bloqueadas durante o período autoritário, foram retomadas.

Pretendemos mostrar que a implantação da política não foi bem-sucedida, em virtude da complexidade da reformulação do sistema de saúde no Brasil. Tal questão ultrapassa o campo específico do setor saúde. Indicamos três pontos problemáticos na viabilização da mudança do modelo do sistema de saúde: os limites ou extensão desse processo, as contradições e os apoios para a implementação da Reforma Sanitária.

A respeito dos limites, procuramos discutir a relação entre democracia e reformas. São várias as dimensões desta relação:

- o grau de profundidade das reformas, o timing das mesmas;

- a capacidade, ou não, de o estágio atual da democracia absorvê-las; 
- a ameaça virtual às forças políticas consolidadas antes do exercício da democracia;

- a existência de um cálculo estratégico que permita a implantação das mudanças, realizado em prol da Reforma.

Acreditamos que a proposta da Reforma Sanitária somente é viável no contexto da transição à democracia. No entanto, tal afirmação merece discussão específica já que as diretrizes da Reforma Sanitária implicam profundas transformações na concepção dos direitos de cidadania e na atuação política do governo, de modo a possibilitar o exercício desses direitos. A democracia per se comporta ou não tais transformações? Parece que esta não é uma questão simples nem evidente.

As contradições surgiram no âmago da atuação dos próprios grupos que sustentaram a Reforma Sanitária e que integraram o Movimento Social em Saúde. Cada um deles apresentava grande heterogeneidade na composição de seus membros, o que implicava múltiplos interesses. Porém, essa diversidade não era evidente no momento da formulação da política, o que é compreensível devido ao papel de oposição que o Movimento Social em Saúde, como um todo, sustentou em relação ao regime autoritário e às políticas de saúde predominantes naquele período.

De fato, as diferenças entre interesses variados estavam diluídas na atuação em bloco do movimento por ocasião da transição à democracia, só vindo à luz no momento da consolidação democrática e, portanto, da implantação da Reforma Sanitária. As contradições entre os grupos, aliadas à sua maneira complicada de interação, acrescentaram mais um obstáculo no já difícil percurso da implementação da política de saúde.

Por último, a respeito dos apoios, o que se pretende discutir não se refere a grupos específicos, no setor saúde, que favoreceriam a Reforma, já que nosso interesse se localiza na questão política mais geral. Um processo desse tipo só pode ser viabilizado com o incentivo e o sustentáculo do Estado. Neste sentido, torna-se necessário discutir questões tais como: que Estado é este? Qual a relação entre Público e Privado? Qual o tipo de democracia requerida para a implementação de reformas que signifiquem redistribuição de bens - a saúde neste caso - para populações que, em condições de carência, não têm acesso à mesma?

Antes de detalharmos os capítulos que compõem o corpo do trabalho, gostaríamos de incorporar algumas reflexões teórico-metodológicas que o 
subsidiaram. A teoria política tem analisado os processos de transição e ulterior consolidação da democracia após períodos de autoritarismo político, sob uma perspectiva centrada, de maneira quase exclusiva, nos procedimentos e na sistemática política envolvidos na construção de um sistema de governo democrático.

Análises mais recentes (Schmitter, 1991b) discutem o estabelecimento de regimes democráticos como condição necessária para a consolidação da democracia. Entende-se por regime democrático a capacidade reprodutiva da democracia, ou seja, a capacidade que o governo e a sociedade possam ter para gerar comportamentos democráticos, o que significa ir além do domínio estritamente político na discussão da democracia.

Este caminho conduziu às possíveis relações entre a constituição da democracia - na medida em que esta é entendida na ótica do redimensionamento das relações Estado/Sociedade - e o campo específico da saúde, compreendido como modalidade de política social que adquire o valor de um bem a ser usufruído por todo e qualquer cidadão e que o Estado tem a obrigação de prover.

A partir desse enfoque, a reformulação da política de saúde, ou mais especificamente a Reforma Sanitária, passou a ter papel de destaque no próprio processo de construção da democracia. Não somente porque essa última atualizou, no plano específico da política pública, as dificuldades encontradas na afirmação da democracia, mas, principalmente, porque a Reforma Sanitária constituiu-se cenário privilegiado da evolução do próprio processo democrático, ressaltando a relação entre democracia e Reforma.

O tema, pela complexidade, obrigou-nos a refletir sobre aqueles aspectos que consideramos relevantes e aos quais daremos prioridade na análise tanto das relações Estado/Sociedade no processo de construção de um regime democrático quanto a respeito do tipo de abordagem.

Embora exista o risco de se incorrer em uma simplificação desse enfoque, que tem pretensão de iluminar o lado obscuro do prisma, procuraremos sintetizar a idéia sobre a qual se sustentou a realização deste trabalho, para expor, posteriormente, os principais conteúdos e procedimentos que o compõem.

A implementação da política de saúde está imbricada, por um lado, ao processo de democratização do País e às mudanças na esfera do Estado e das relações Estado/Sociedade; por outro, à maneira pela qual os diversos interesses que compõem o Movimento Social em Saúde lidam entre si e se fazem 
representar nas instâncias institucionais da política de saúde. Neste sentido, nenhum desses enunciados pode ser visualizado per se.

Esperamos que a discussão teórico-conceitual, efetuada na primeira parte do livro, e a análise da dinâmica do comportamento de nossos protagonistas vinculado a cenários, nos capítulos subseqüentes, colaborem para desvendar a peça para o leitor.

O trabalho foi dividido em três partes, compostas, em seu total, por seis capítulos. Na Parte I desenvolvemos uma análise teórica a respeito da construção da ordem democrática no Brasil, tendo por base o processo histórico iniciado com a transição à democracia, e do estabelecimento de alguns parâmetros conceituais que consideramos substantivos na abordagem de nosso objeto. Este bloco consta de três capítulos: no primeiro, objetivamos a noção de democracia; no segundo, a reforma do sistema de saúde; no terceiro, os movimentos sociais em saúde.

No capítulo 1 discutimos a transição à democracia e o processo de construção e/ou consolidação da mesma, estendendo a noção da democracia para além dos procedimentos tidos como necessários ao estabelecimento da democracia política. A discussão incluiu cinco pontos: Esfera Pública/Privada, Indivíduo/Sociedade, Eqüidade/Justiça, Democracia e Reformas. O tratamento dos temas aproximou-nos da definição de relações teóricas conexas entre movimentos sociais em saúde, política de saúde e construção democrática.

No capítulo 2 analisamos a reformulação da política de saúde como política social, sua origem e desenvolvimento até a culminância na proposta da Reforma Sanitária. Esta foi compreendida como um caminho de reconstrução da democracia por intermédio de reformas parciais ou, dito de outra maneira, de consecução da democracia pela via do estabelecimento de 'regimes parciais' democráticos. A visão das políticas de saúde, sob a perspectiva das políticas sociais, obrigou-nos a aprofundar o campo teórico-conceitual envolvido nessa área e sustentou a discussão a respeito dos processos de formulação e implementação de políticas sociais, em razão da necessidade de subsidiar teoricamente a análise do processo de implantação da Reforma Sanitária.

O capítulo 3 introduz o papel dos movimentos sociais em saúde nesses dois momentos - a formulação e a implantação da política de saúde -, enfatizando o particular desempenho desses movimentos à luz das diversas teorias da ação coletiva. A reflexão crítica a respeito de tais teorias, a partir dos movimentos sociais em saúde, possibilitou-nos identificar as adequações, proxi- 
midades e distanciamentos entre os diversos enfoques que elas apresentavam e o desenrolar da atuação política dos atores por nós privilegiados. Adquirimos, dessa forma, um arcabouço teórico para pensar as políticas de saúde nos processos de transição e construção da democracia desde a perspectiva atual dos atores envolvidos e sua relação com o Estado.

$\mathrm{Na}$ Parte II consideramos o desenvolvimento histórico da atuação dos movimentos sociais em saúde em relação ao processo de reformulação do sistema de saúde. E isso com base na análise dos dados de uma pesquisa que coordenamos sobre o papel do Movimento Popular em Saúde e o Movimento Médico no processo de formulação e implementação da política de saúde nas duas últimas décadas. Dividimos esta parte em dois capítulos: um referido ao Movimento Popular em Saúde, o outro, ao Movimento Médico.

No capítulo 4 estudamos o Movimento Popular em Saúde, no período que se estende de 1979 a 1990. A composição deste, em suas origens, relacionou-se às experiências locais de saúde em algumas regiões do País em torno de associações de moradores, sociedades de fomento e outras entidades de bairro. O movimento estadual, e logo nacional, de federações e confederações de associações de moradores de bairros e de favelas forma-se desde o início até meados da década de 80. O Movimento Popular em Saúde, que assim se autodenominou nos encontros de caráter nacional, foi parte constitutiva dessas federações e confederações. Por fim, houve uma importante desarticulação do Movimento Popular em Saúde em fins dos anos 80 que se caracterizou por notáveis diferenças regionais aprofundadas e também pela descentralização do sistema de saúde e pela formação dos Conselhos de Saúde, ainda que o movimento tenha continuado a existir nacionalmente.

No capítulo 5 descrevemos a atuação do Movimento Médico no período compreendido em 1976 e 1990, com uma perspectiva que incluiu não só as formas associativas sindicais dos médicos como categoria profissional, mas o conjunto das associações médicas - tanto as que regulam o exercício da profissão quanto as de caráter técnico-científico e as que congregam os profissionais médicos na discussão de questões específicas da profissão médica. As entidades analisadas foram: o Conselho Regional de Medicina do Estado do Rio de Janeiro (Cremerj), a Sociedade Médica (Somerj), a Sociedade de Medicina e Cirurgia do Estado do Rio de Janeiro (SMCERJ) e o Sindicato dos Médicos (Sinmed). O levantamento do material e as entrevistas realizadas com lideranças das associações médicas de entidades localizadas no estado do Rio de Janeiro cobrem o período que se estende de 1983 a 1990. 
Na Parte III é investigada a dinâmica da relação entre os atores e o processo de implementação da Reforma Sanitária nos anos 90. Também nesta parte são abordados o próprio processo de implementação da Reforma Sanitária, a descentralização do sistema de saúde e os Conselhos de Saúde.

No Capítulo 6 exploramos até onde se avançou no estabelecimento dos procedimentos legais previstos constitucionalmente para o setor saúde e qual o estado da arte na implementação de Reforma Sanitária até fins de 1993. Os obstáculos criados no desenvolvimento da municipalização; um exame da IX Conferência, dado o caráter significativo dessa instância decisória da política de saúde; a extinção do Instituto Nacional de Assistência Médica da Previdência Social (Inamps), já que ele era - desde sua criação em 1977 - órgão centralizador das decisões recebidas à política de saúde. Especial ênfase é dada ao processo de descentralização nos estados e municípios, eixo central na implementação da política de saúde. Consideramos marco de referência teórica na análise do processo de descentralização as concepções que associam essa noção à democratização do Estado. Neste sentido, interessou-nos abordar o estágio atual do processo de municipalização, para sublinhar as diferenças entre algumas das experiências investigadas no decorrer do capítulo e detectar quais os motivos que proporcionaram maior sucesso a umas que a outras.

O capítulo trata também da formação e atuação dos Conselhos como instâncias de caráter deliberativo da política de saúde nas quais os usuários, suas entidades e os movimentos sociais deveriam deter 50\% da representação nos termos do regulamento da Lei Orgânica de Saúde.

$\mathrm{Na}$ conclusão, indicamos como a visão original com a qual pretendíamos abordar o objeto de estudo deste trabalho sofreu deslocamentos. Assim, a partir do tema eleito - 'os movimentos sociais em saúde em face das políticas de saúde’ - e do marco teórico que sustentou essa forma de abordagem 'o redimensionamento das relações Estado/Sociedade num âmbito específico da política social no curso do processo de transição e consolidação da democracia' -, passamos a conformar metodologicamente o foco de análise em três aspectos: a trajetória e o papel dos movimentos sociais em saúde; o grau de definição da política de saúde; o processo político mais amplo de constituição de um regime democrático. Neste sentido, retomamos nas conclusões, à luz dos resultados, as questões teóricas desenvolvidas no início do livro.

Salientamos que a Reforma Sanitária brasileira constituiu-se em um "regime de democratização parcial” (Schmitter, 1991b), definimos a maneira pela 
qual se estabeleceu o percurso da mesma e, considerando-se as dificuldades para a constituição de um regime democrático no Brasil, explicitamos quais as possibilidades para a implementação da política de saúde, dado o estágio alcançado pelos movimentos sociais em saúde. 
Parte I 


\section{A Construção da Democracia: algumas questões históricas e teóricas}

$\mathbf{O}_{\text {s anos }} 80$ constituíram um marco, na política brasileira, do processo de democratização do País. Um amplo espectro de forças políticas da sociedade como sindicatos, movimentos populares e partidos políticos - empreenderam uma luta política que conseguiu aglutinar forças diversas na conquista de eleições para a Presidência da República. Essa luta em prol da democratização estabeleceu-se na integração da oposição à ditadura militar ante a proposta das Forças Armadas de fazer uma abertura "lenta, gradual e segura".

A transição à democracia no Brasil é considerada, pelos autores que tratam do assunto, como uma decisão unilateral dos militares no marco do regime autoritário. No entanto, implicou um processo de alta complexidade - em grande parte por causa de sua duração e no qual as forças sociais tiveram papel essencial - que a realimentou, estabelecendo uma via de mão dupla no desenvolvimento da mesma.

O papel dos movimentos sociais, dos sindicatos operários, do sindicalismo de classe média, dos partidos de oposição, enfim, o ressurgimento da sociedade civil foi de fundamental importância para minar as bases da estabilidade do regime autoritário. Desse modo, parece-nos de interesse rediscutir a maneira como se operou a transição no Brasil e os caminhos da consolidação democrática.

A maneira como são restabelecidas as relações entre Estado/Sociedade passa pela criação de regras e procedimentos institucionais que redefinem a forma como os interesses são representados e se traduzem em políticas governamentais específicas no processo de consolidação. Tal processo tem sido longo e tortuoso, já que até hoje os procedimentos não estão plenamente instituídos.

O processo de transição à democracia atravessou diversos momentos - no extenso período de dez anos, uma das mais longas transições conhecidas -, 
o que dificulta a interpretação do tipo de transição e conseqüentemente a previsão dos caminhos para a consolidação da democracia.

Os militares tiveram papel protagônico na definição e no calendário da transição em seu primeiro momento: de 1974 a 1979. Schmitter \& Karl (1991) identificam quatro tipos ideais ou modelos de transição à democracia:

- pactuada - acontece sempre que as elites chegam a um acordo entre elas;

- imposta - quando há uma decisão unilateral para estabelecer mudanças no regime;

- reformista - em que as massas se mobilizam e impõem uma solução sem violência;

- revolucionária - quando as massas, pela via armada, derrotam militarmente os antigos dirigentes.

O Brasil, para esses autores, estaria incluído no tipo de transição imposta. Acreditamos ter sido esse o caso na primeira fase do processo. Em um segundo momento, que se estende até a sucessão do general Figueiredo, começa a existir certa confiança por parte da população no que diz respeito à continuidade do processo de abertura e do afrouxamento da repressão. Surgem formas de organização social e política que se expandem pelo País inteiro e obrigam a mudanças na orientação do processo.

Ainda que setores das Forças Armadas - os chamados 'duros' - tentassem impor um retrocesso no processo de democratização, em 1979, não o conseguiram, tendo preponderado a formulação de um pacto político entre as elites e a oposição 'moderada', o que possibilitou uma sucessão presidencial negociada. O caráter de pacto, exposto por O’Donnell com grande precisão, se ajusta perfeitamente a esse segundo momento da transição política.

O'Donnell (1988) distingue dois tipos de transição à democracia: a por colapso e a pactuada. No primeiro caso, trata-se de regimes burocrático-autoritários fortemente repressivos e cujas políticas econômicas foram enormemente destrutivas. Geram um vazio político ao seu redor, perdem os apoios políticos e, ao não conseguirem controlar o processo político, caem estrepitosamente. As transições por colapso, ainda que ocorram em contextos econômicos catastróficos, comportam menor condicionamento político para as forças de oposição e maior liberdade dos governos democráticos. No segundo caso, trata-se de regimes que tiveram melhor desempenho econômico e nos quais o uso da repressão foi menos brutal e extensivo. 
O relativo êxito econômico significou, aqui, a manutenção das alianças com os setores médios e empresariais que se beneficiaram com as políticas econômicas do regime autoritário. Dessa maneira, as elites civis e militares tiveram condições de encaminhar uma transição pactuada, impondo às forças de oposição condicionamentos no estabelecimento de governos democráticos. Esse tipo de transição traria à cena política a reedição de velhos pactos que configuraram historicamente as relações entre Estado/Sociedade no Brasil.

Uma das características mais marcantes do Estado brasileiro é precisamente o seu autoritarismo. Historicamente, a sociedade brasileira apresenta traços profundamente elitistas e excludentes, em parte herança do escravismo do período colonial e do caráter oligárquico das classes dominantes. Neste sentido, o Estado impôs seu domínio à sociedade através do exercício do patrimonialismo político, do clientelismo e da incorporação das classes 'subalternas' por meio de mecanismos de cooptação que garantiram a supremacia das elites no exercício da política.

No entanto, o caráter da transição pactuada e da reedição de velhos pactos não é suficiente para explicar o grau de complexidade que adquiriu o desenvolvimento democrático e a atuação dos diversos atores sociais e forças políticas que emergiram com a transição à democracia. Embora a histórica relação entre Estado/Sociedade tenha sido atualizada e exacerbada pelo regime militar, o processo de transição à democracia originou uma forte crítica na sociedade brasileira a respeito da modalidade autoritária predominante no Estado. Essa postura foi acompanhada pela compreensão da noção de cidadania como um conjunto de direitos a serem alcançados pela sociedade como um todo.

Assim, as dificuldades para a consolidação da democracia no Brasil requerem uma discussão específica sobre a relação entre democracia e Estado que exige conceitualizar a democracia em relação à esfera pública e privada, ao indivíduo e à sociedade, à justiça e à eqüidade. Tais questões são, a meu ver, centrais se considerarmos o estabelecimento de uma democracia no Brasil.

Os dilemas enunciados a seguir permearam a discussão teórica empreendida:

- Enorme percentual (50\%) da população que beira o limite da pobreza absoluta; a pressão social dessas camadas sociais se expressa através de formas de resistência violenta. Essas formas de pressão e resistência criam sociedades e governos paralelos nos bairros miseráveis das grandes metrópoles, ameaçando a própria sobrevivência da ordem social e política. Trata-se de situação bem próxima àquela assinalada por Hobbes de a "guerra de todos 
contra todos", na qual ou uma nova ordem social e política é procurada através do estabelecimento de um regime democrático ou então a ameaça de um "poder absoluto", não necessariamente militar - como as tentativas do Governo Collor demonstraram -, pode concretizar-se.

- Paralelamente, há propostas de reformas substantivas no âmbito social. Destas, a Reforma Sanitária é a maior expressão, mas a dificuldade na implementação da mesma indica o difícil percurso para a constituição de um sistema político democrático e traz à tona a necessidade de uma discussão da própria noção de democracia. Como se pode compatibilizar uma política reformista que necessariamente exige profundas transformações do Estado com uma situação do tipo ora enunciado? Qual a relação entre Reforma e democracia no Brasil de hoje?

- Uma última questão em relação a tal problemática é a diversidade de interesses em jogo no processo de construção da democracia - interesses de indivíduos, grupos, sindicatos, entidades profissionais, usuários de diversos sistemas. Como lidar democraticamente com a diversidade? A partir da própria diversidade em um movimento de mão dupla. Como indivíduo na busca ativa de relações compreendidas em permanente associação em grupos, movimentos e/ou instituições. Já na perspectiva do sistema político, de forma a viabilizar um regime democrático socialmente justo que respeite, mantenha e incorpore ao exercício de governo as diferenças de interesses existentes na sociedade.

Em trabalho recente sobre a consolidação da democracia, o tipo de instituições que a mesma comporta e a forma desses processos, Schmitter postula que a consolidação da democracia atravessaria grandes dificuldades nos países sujeitos simultaneamente a pressões de diferentes modos de transição. $\mathrm{O}$ autor denomina essa situação de Black Hole, ${ }^{4}$ simbolizando, com tal imagem, a situação em que o país 'mergulha' em uma espécie de vazio ocasionado por uma "simultaneidade de lógicas" que impossibilitaria aos atores "ter uma estratégia vitoriosa".

\footnotetext{
${ }^{4}$ São países simultaneamente sujeitos às pressões de diferentes modalidades de transição: as elites autoritárias dominantes acreditam possuir todo o poder em mãos (freqüentemente de uma maneira rápida); as elites políticas de oposição procuram efetuar um pacto entre elas (excluindo as elites dominantes); as massas são mobilizadas nas ruas, trazendo à cena a ameaça da extensão da violência ou de uma saída revolucionária. Nossa idéia é que, com essa simultaneidade de lógicas, é quase impossível os diversos atores terem uma estratégia vitoriosa. O Brasil entrou nessa situação devido à morte prematura de Tancredo Neves, que tirou da cena política o ator mais decidido e capaz de dar uma seqüência ao processo de democratização por meio de resultados pactuados (Schmitter, 1991b:18). [tradução da autora]
} 
A situação política no Brasil encaminhou-se através de linhas de forte tensão política, em que era muito difícil definir as regras e as instituições sobre as quais se assentaria a consolidação democrática. A transição foi uma das mais longas que se conhece: estendeu-se por dez anos, sendo claramente controlada durante os primeiros cinco, até 1979. O escândalo do Riocentro, as denúncias sobre a atuação da repressão e o crescimento das associações da sociedade civil - fossem elas partidos, movimentos ou sindicatos - colocaram limites à atuação das Forças Armadas. Para estas, isso não significou perda de controle no processo da transição, mas obrigou-as a ter maiores cuidados e a efetuar negociações com as forças de oposição.

Nos anos de 1983/1984 aconteceram as maiores mobilizações populares: milhões de pessoas reuniram-se para exigir eleições diretas para a Presidência da República, o que significou uma enorme pressão política sobre as Forças Armadas. O desfecho desse processo foi um complexo emaranhado de negociações políticas entre os militares, as elites políticas e as forças de oposição.

A transição negociada promoveu, em janeiro de 1985, eleições indiretas, por meio de um Colégio Eleitoral que elegeu Tancredo Neves Presidente e José Sarney Vice-Presidente do País. Porém, a maior garantia para o processo de democratização era pela figura de Tancredo, que contava com apoio da maioria.

Com sua morte e assumindo o comando do País o vice-presidente José Sarney, se produziu um grande vácuo político que colocou o Brasil em uma situação do tipo descrito por Schmitter. A equipe do governo já havia sido escolhida por Tancredo Neves: tratava-se basicamente de uma composição que refletia as diversas forças políticas que tinham participado da negociação, à qual faltava o comando.

Essa falta de comando deixou imersa a Nova República numa configuração política bastante distante da democracia. De uma parte velhos pactos e velhas elites, já não militares mas civis, dentre as quais Sarney foi um representante, justificaram reapropriação do espaço nas instituições do Estado, enquanto usavam como apelo o slogan Tudo pelo Social. De outra, nas forças políticas de oposição, existia consenso a respeito da necessidade de implementar políticas reformistas que significassem alguma forma de compensação ao crescimento das enormes desigualdades sociais que o regime militar havia produzido.

A política econômica refletiu essas contradições políticas. Implementou-se o Plano Cruzado como contenção da inflação, ao mesmo tempo que desapareciam os produtos de consumo massivo, sem que o governo tivesse a suficiente 
autoridade para punir os empresários, a oligarquia rural ou as empresas multinacionais. Tentou-se aumentar as exportações, mas o setor exportador considerou os preços internos não competitivos. A renegociação da dívida externa emperrou, já que a política econômica do governo não correspondia às políticas de 'ajuste' ditadas pelo Fundo Monetário Internacional (FMI).

Enquanto isso, a dívida do setor público continuava aumentando, já que os compromissos políticos do Governo Sarney com as velhas elites políticas se efetivavam mediante o preenchimento de cargos na máquina estatal, que, por sua vez, funcionava como plataforma eleitoral de políticos, que, ao velho estilo, usavam a máquina do Estado para trocar votos por favores. Ou seja, a política clientelística foi a tônica do governo da Nova República. Simultaneamente algumas transformações aconteciam nos aparelhos de Estado, na medida em que alguns representantes da oposição eram chamados a ocupar cargos sem que isso significasse transformações substantivas nos vícios da máquina estatal.

No entanto, no Brasil, nos momentos de maior acirramento das contradições, há uma homogeneização do discurso político, o que induziria a pensar na existência de acordos políticos entre forças conflitantes. Em verdade, trata-se exatamente do contrário: o discurso progressista das elites conservadoras não tem nenhuma correspondência com a conhecida atuação política das mesmas. Trata-se de impedir - via os meandros burocráticos da máquina política estatal - a ocupação direta de postos-chave (negociatas econômicas que envolvem grandes transações), sofisticação tecnocrática, compra de votos, transformações substantivas do Estado brasileiro.

Tais procedimentos, visceralmente opostos à democracia, se fazem em nome da mesma, convivem com reformas parciais e só vêm à tona por meio de grandes escândalos públicos, onde accountability é somente uma conseqüência forçada à qual os governantes são compelidos pela via dos fatos.

Assim, a Nova República, não nas intenções mas nos resultados, produziu uma paralisação na construção das instituições e procedimentos democráticos, questões fundamentais para que seja possível passar da transição para a consolidação da democracia. Em outras palavras, para que o peso da modalidade autoritária, clientelística e patrimonialista da atuação política do Estado brasileiro, incrementada ainda pelo exercício da política dominante do regime autoritário, não se constitua na determinação principal que impeça a criação de instituições e procedimentos democráticos que possibilitem o exercício permanente ou a reprodução da democracia, é preciso considerar algumas questões. 
A principal questão é que, diferentemente do momento da transição, a consolidação da democracia requer a constituição de um regime democrático. Os princípios criados por Dahl (1979) como os procedural minimum - voto secreto, sufrágio universal, eleições regulares, competição partidária, liberdade de associação, transparência do executivo - são necessários, mas não suficientes para garantir que não se retroceda a uma situação anterior ou para afiançar uma democracia capaz de se reproduzir. Trata-se de procedimentos mínimos sem os quais não poderia haver democracia ou poliarquia, como ele a denominou, mas, ainda que sejam imprescindíveis para eleger governos democráticos, não garantem per se regimes democráticos.

A diferença entre um governo democrático e um regime democrático seria dada pela transformação de um padrão ou traço democrático em uma estrutura (Schmitter, 1991a). Qual o significado da existência de uma estrutura política democrática? Denominamos de estrutura democrática a capacidade reprodutiva da democracia, ou seja, a capacidade de o governo e a sociedade virem a autogerar comportamentos políticos democráticos.

É necessário, aqui, chegar-se a um acordo a respeito do que seja a idéia de 'estrutura democrática', o que remete à própria noção de 'democracia'. Percorrer a noção de democracia ao longo da história é um árduo caminho já desenvolvido pelos mais diversos pensadores e através das mais diversas perspectivas. Não pretendemos nos aventurar por ele. Procuraremos sustentar a argumentação nos dilemas atuais que se colocam, para gerar uma estrutura política democrática no Brasil, ao levar em consideração a praxe do exercício da política, das relações sociais e dos comportamentos individuais.

A democracia, em sua acepção política, refere-se à modalidade de governo em que, por meio de eleições, cidadãos livres e iguais escolhem, via sistema partidário, aqueles que serão seus representantes. Em trabalho recente de Schmitter \& Karl (1991:76), afirma-se que:

A moderna democracia política é um sistema de governo no qual os governantes são cobrados por suas ações no domínio público por cidadãos que atuam indiretamente através de concorrência e cooperação de seus representantes eleitos. ${ }^{5}$

É necessário acrescentar, ainda, que as modernas democracias têm um importante viés societário que se sustenta na tradição social-democrata européia

Tradução da autora. 
dos últimos 50 anos, em razão da qual a democracia política é hoje indissoluvelmente relacionada a certos padrões de bem-estar social.

Entretanto, ainda considerando esta definição 'ampliada' de democracia, resta aproximarmo-nos da consolidação da democracia ou da maneira pela qual regimes democráticos viriam a se estabelecer. Incorporando a idéia de Giddens (apud Schmitter, 1991a) de estruturação, para a qual as noções de rotinização, institucionalização, estabilização e 'reificação' foram usadas primeiramente para conhecer este fenômeno. No trabalho anteriormente mencionado, define-se regime (ou sistema de governo) como:

um conjunto de normas e regras - padrões - que determinam a forma de acesso aos principais cargos públicos, as características dos atores admitidos ou excluídos, as estratégias que esses atores podem utilizar para obter acesso aos cargos públicos, as regras a serem seguidas para decidir as árduas questões públicas. Melhor dizendo, o conjunto deve ser institucionalizado - isto é, as regras devem ser habitualmente conhecidas, praticadas e aceitas pela maioria, mesmo que não seja por todos os atores. Crescentemente, os mecanismos privilegiados de institucionalização constituem-se em um corpo escrito de leis incorporado numa constituição formada por normas políticas que podem ter uma base informal sustentada no costume ou na tradição. (Schmitter \& Karl, 1991:76) ${ }^{6}$

Sob essa perspectiva, acredito que a consolidação da democracia política é possível sempre que:

- comportamentos políticos democráticos tenham sido internalizados com antecedência pelos atores políticos;

- exista consenso entre os atores políticos a respeito do fato de que a diversidade de interesses presentes na sociedade impõe, de uma parte, substituir a satisfação imediata dos interesses próprios por interesses de caráter coletivo. A condição de possibilidade da afirmação anterior seria dada pelo consentimento tácito dos atores sociais de que a democracia garantiria a satisfação em um momento posterior dos próprios interesses. Essas duas precondições não são dadas e, no caso do Brasil, são praticamente inexistentes.

\footnotetext{
Tradução da autora.
} 
Schmitter (1991a:9) ${ }^{7}$ considera que a consolidação da democracia consistiria em transformar padrões ad hoc em 'estruturas' que assegurem procedimentos/canais de acesso, inclusão/exclusão dos atores, recursos/estratégias para a ação e regras/normas a respeito da tomada de decisões de acordo com um standard específico: que o princípio retor da democracia é a 'cidadania'.

Reproduzimos a citação porque nos parece particularmente incitante, assim como um desafio central para se refletir em relação à constituição de uma estrutura democrática. Tendo-se isso por base, acreditamos que a possibilidade de abrir uma senda nessa intricada floresta, no sentido de uma metáfora uma hobbesiana, poderia acontecer a partir da reflexão dos pares enunciados: esferas pública/privada, indivíduo/sociedade, justiça/eqüidade. Parece-nos este o momento apropriado para refletir sobre o que diz respeito à maneira pela qual os atores sociais e políticos poderiam 'preferir, com prazer', ter comportamentos democráticos ou uma atuação política democrática.

\section{Esfera Pública / Esfera Privada}

Essas duas categorias de análise, pensadas pelo liberalismo a propósito do Estado como duas ordens - a segunda correspondendo à esfera da sociedade na qual se realizam os interesses dos indivíduos; a primeira, à esfera do Estado como o espaço em que se desenvolvem os assuntos de caráter público -, ordenam e separam o indivíduo da sociedade e separam esta última do Estado.

Tal ordenação e separação não são apenas uma construção ideal do pensamento, mas obedecem à necessidade de fundar o Estado moderno não somente como conseqüência da dissolução da ordem feudal. O Estado virá a ser a maior construção política, a mais aperfeiçoada organização político-institucional, produto da transformação da sociedade feudal com o surgimento da burguesia como 'classe universal' ou expressão do 'homem moderno'.

\footnotetext{
"a idéia básica, comum a tudo isto, é que as relações sociais se tornem estruturas, ou seja, padrões de interação ocorram regulamente, estejam dotados de significado e sejam suficientemente capazes de motivar condutas, de modo que possam vir a ter um funcionamento autônomo para resistir a mudanças induzidas do exterior. Simplificando, estruturas são coletividades nas quais 'o todo é maior que a soma das partes’. As estratégias e normas dos indivíduos dentro delas são restringidas pela totalidade. As ações e metas da estrutura não são redutíveis àquelas de suas partes componentes. O que se precisa é de uma definição mais específica e de teorias da estruturação/ institucionalização/estabilização/rotinização que capturem esta modalidade e expliquem como ela poderia ser adotada, e também porque os atores poderiam preferi-las com prazer." [tradução da autora]
} 
Assim, a idéia do Estado como instância que se erige por cima dos homens particulares e também da sociedade adquire dimensão singular não apenas como idéia, mas, sobretudo, como estrutura jurídico-institucional, política e administrativa da nação.

Essa nova ordem social burguesa se caracteriza por ser formada por indivíduos livres e iguais, que se satisfazem no mercado, sendo esta satisfação não um encargo do Estado, mas da iniciativa privada. Trata-se de indivíduos livres, já que não estão ligados ao modo de exploração feudal, nem à servidão do trabalho da terra, nem à entrega do produto da mesma ao 'senhor'. As formas de produção feudal e a sua ordenação política perdem valor econômico, social e político ante o rápido processo de acumulação capitalista que a troca de mercadorias facilita por intermédio do mercado. Este requer de indivíduos livres que tenham o direito a escolher o lugar e o tipo de trabalho desejado, a liberdade de ir e vir, morar onde quiser e se expressar a respeito de desejos e opiniões sem serem constrangidos pela ordem política - o Estado. Assim, a condição de igualdade é suposta pelo mercado na medida em que os indivíduos se igualam no ato da troca; cada indivíduo é igual a si mesmo e aos outros no exercício do ato econômico de comprar ou vender o que quer que seja, independentemente do valor daquilo que esteja sendo trocado. Dito de outra maneira, o valor desigual passa a ser colocado na mercadoria como objeto da troca, sem que este contamine seus possuidores. Essa fantástica construção do pensamento liberal não é nada mais do que o que Marx denominou 'fetichismo da mercadoria'.

Tal ato simbólico e, ao mesmo tempo, real - a igualdade formal e a desigualdade real - é também fundador da cidadania. Neste sentido, a mercadoria pode ser equiparada à noção de cidadania, no que ambas têm em comum: seu componente 'fetichista'. Os indivíduos são, em relação ao mercado, à sociedade e/ou esfera privada, o que os cidadãos são em relação à esfera pública e/ou ao Estado. $\mathrm{O}$ ato de dar ao indivíduo o status de cidadão vai permitir justificar que a esfera pública regule relações particulares entre indivíduos privados, equiparando os indivíduos como cidadãos.

De fato, a intervenção da esfera pública na ordem privada se sustenta nas necessidades do próprio processo de acumulação, sejam essas explicitadas ou não. É indiscutível a presença de alguns interesses privados na ordem pública, assim como o fato de esfera pública 'representar' mais alguns interesses que outros. 
Tal afirmação é bem exemplificada pela intervenção do Estado ainda nos primórdios do capitalismo, ao responder às exigências da burguesia para o melhor andamento do processo de acumulação, tais como: os decretos sobre vestimentas, a criação de taxas e impostos ou, nos momentos em que faltava o trigo, a proibição do consumo de pão nas sextas-feiras (Habermas, 1984); ou mesmo pela intervenção da ordem política para garantir a própria sobrevivência do mercado, como as leis sobre terras e a regulamentação da jornada de trabalho.

A cidadania outorga aos indivíduos certa identidade coletiva, uma vez que, como cidadãos, passam a formar parte da nação. Mas esse aspecto da cidadania é contraditório, porque, ao mesmo tempo que possibilita a percepção do indivíduo como parte de um todo maior, essa totalidade não lhe é própria. A esfera pública como expressão da cidadania, na ordem liberal burguesa, é circunscrita aos possuidores de bens, sejam terras, instrumentos de trabalho ou mercadorias. Mas, simultaneamente, a esfera pública é separada dos produtores privados - sejam eles assalariados ou proprietários - e é isso que a constitui como o espaço no qual estão 'representados' os interesses públicos do conjunto da comunidade e, ainda, o que permite que se legitime como autoridade pública o Estado de Direito.

A contradição embutida na idéia de cidadania, anteriormente mencionada, é sustentada na existência de direitos e, portanto, na possibilidade de satisfação destes, o que não significa necessariamente a efetivação da satisfação. Esse aspecto contraditório da cidadania é que possibilitou a luta pela efetiva conquista dos direitos de cidadania e a consecução dos direitos sociais como a expressão mais desenvolvida desta, à qual se chegou depois de lutas sociais que levaram dois séculos. O momento da obtenção de direitos sociais que Marshall (1967:57113) denominou "cidadania completa", referindo-a ao modelo clássico da obtenção de direitos exemplificado pela Inglaterra, teve e tem percursos históricos específicos nas diversas realidades nacionais.

O efetivo preenchimento dos direitos sociais nos Estados democráticos modernos, expressado pelo Welfare State, é, talvez, o momento de maior aproximação da esfera pública ao 'público', termo este usado aqui para designar a presença, na esfera do Estado, de interesses de classe diversos dos da classe dominante. As sociais-democracias modernas conseguiram pluralizar o Estado, ao incorporar os interesses das classes subalternas a partir do reconhecimento da desigualdade social como inerente ao modo de produção capitalista, e atenuar essas desigualdades pelo exercício da democracia social lítica sem interferir 
no processo de acumulação capitalista. Esse percurso da cidadania levou a uma interpenetração crescente da esfera privada pela esfera pública e vice-versa. ${ }^{8}$

Essa sobreposição não significa mais que a constatação de que a participação social política, a partir da condição de 'cidadania', alterou o caráter restrito da esfera pública. Tais mudanças se refletiram no Direito como resultado das transformações no Estado.

Se refletirmos agora sobre essa questão da perspectiva dos indivíduos em sociedade não se torna muito difícil concluir que posso aceitar que meus interesses não estejam incluídos na esfera pública sob duas condições: a obtenção, no presente, de algum ganho pensatório e a possibilidade de sua inclusão em um futuro. A primeira condição é soluvelmente ligada à segunda, pois sua comprovação é a prova do cumprimento da outra. Trata-se de condições, ambas contidas no exercício da cidadania: ser cidadão permite usufruir de direitos. Remetamo-nos, por exemplo, à condição de libertos da servidão à terra e ao senhor feudal, à 'livre' escolha de ir e vir, ao direito de defesa sob injusta acusação por crime não cometido ou ao direito de falar livremente.

Dos direitos civis, os indivíduos podem fazer uso quando quiserem, desde os primórdios do capitalismo até os dias de hoje. Quanto isso tem de ilusão corresponde à segunda condição enunciada; tais direitos não são iguais para todos, mas, se em parte o são, talvez um dia possam vir a ser completamente e isso na medida em que a parcialidade da esfera pública não seja absoluta. Em outras palavras, sempre que a esfera pública constitua um espaço a ser definido pela disputa de interesses opostos, e por vezes enfrentados, na qual exista a possibilidade de que interesses não satisfeitos no presente possam ser realizados no futuro.

Outra leitura sobre o caráter dessa interpenetração é dada pela manutenção e ampliação, no interior da esfera pública, de interesses de grupos privados, exemplificada pelo Brasil do regime autoritário e, em grande parte também, da transição. O processo de desenvolvimento econômico que o País atravessou durante o regime autoritário - caracterizado por taxas elevadas de crescimento econômico, pelo importante investimento de capital internacional, tanto nos setores produtivos como nos investimentos públicos, e pela alta

\footnotetext{
"A partir da esfera privada publicamente relevante da sociedade civil burguesa constitui-se uma esfera social repolitizada, em que instituições estatais e sociais se sintetizam em um único complexo de que não é mais diferenciável. Essa nova interdependência de esferas, até então separadas, encontra a sua expressão jurídica na ruptura do sistema clássico de Direito Privado (...). Na sociedade industrial organizada como Estado-social multiplicam-se relações e relacionamentos que não podem ser suficientemente ordenados em institutos quer do Direito Privado, quer do Direito Público; obrigam, antes, a introduzir normas do assim chamado Direito Social" (Habermas, 1984:177).
} 
concentração de renda com a marginalização de amplos setores da sociedade criou uma sociedade complexa e segmentada.

Alguns autores têm se referido à sociedade brasileira como a 'Belíndia' mistura de Bélgica e Índia -, como forma de dar conta da existência de mais de um Brasil: um altamente desenvolvido e rico, e outro extremamente subdesenvolvido e pobre. Isto precisamente foi possível pelo encurtamento da esfera pública, devido à intervenção e ao papel crescente que grupos econômicos e políticos tiveram na mesma.

Dessa forma, o 'público' é barrado do Estado, e este continua a incrementar a capacidade já existente do exercício público de interesses privados (leia-se de grupos) até a não diferenciação entre o que é público e o que é privado.

\section{Indivíduo / Sociedade}

O homem em sociedade deixa de ser um indivíduo para ser sujeito de si mesmo e dos outros no processo de interação social. Só posso me reconhecer como indivíduo em sociedade porque o reconhecimento dos meus direitos, ainda que imperfeito, é a comprovação da possibilidade de satisfação destes no futuro.

Considerando que a teoria liberal separa o indivíduo da sociedade e a esta trata como um agregado de indivíduos, apresentando-a, dessa maneira, atomizada, torna-se importante destacar o tratamento que Freud dá ao tema, por ser o primeiro teórico que, a partir de uma perspectiva do indivíduo, enfocou a questão sob uma visão societária. ${ }^{9}$

A condição da civilização para Freud é colocada na renúncia ao desejo, mas isso se torna possível não exclusivamente como um ato de repressão im-

9 "Nós agora temos que considerar o último, mas não certamente o menos importante dos componentes da cultura, a saber, o caminho no qual as relações sociais, como um objeto sexual para outros, como membro de uma família ou do Estado. É especialmente difícil neste assunto não ter preconceitos que obedecem a padrões ideais e determinar com exatidão o que é especificamente cultural. Possivelmente poder-se-ia começar por estabelecer que a primeira tentativa para regular as relações sociais conteve de maneira acabada os elementos essenciais da civilização. Se esta tentativa não tivesse sido feita, estas relações seriam sujeitas ao arbítrio dos indivíduos: isto é, o homem mais forte psicologicamente poderia decidir as coisas de acordo com seus próprios interesses e desejos. A vida humana em comunidades apenas se torna possível quando os homens se juntam e isto constitui uma força superior à de qualquer homem isolado e esta unidade se mantém contra toda a singularidade individual. A força deste corpo unido é oposta, com 'Direito', à força de um indivíduo, o qual é condenado à força bruta. Esta substituição do poder pela união dos indivíduos perante um homem singular é um passo decisivo em direção à civilização. A essência disto é que os membros de uma comunidade têm restringido suas possibilidades de gratificação enquanto o indivíduo não tem reconhecido tal restrição" (Freud, 1957:59). 
posto pela vida em sociedade. $\mathrm{O}$ instinto reprimido no indivíduo, para obter o reconhecimento da autoridade - ou dito de outra maneira, trocado pelo amor paterno - é o que possibilita ao homem a formação do superego como restrição. O superego é para Freud a mesma coisa que consciência. Neste sentido, o desejo premente afasta o homem do outro e de usufruir dos benefícios de se associar aos outros, sejam esses benefícios imateriais - não sentir culpa, ser apreciado ou ser amado pelos outros - sejam esses materiais - a produção social é mais lucrativa do que o trabalho individual.

A realização imediata do desejo afasta o homem da capacidade de um domínio mais amplo do mundo e, por sua vez, a capacidade de antecipar resultados é o que lhe permite a postergação do desejo. Essa capacidade de antecipação coloca o homem numa contradição permanente: ser um indivíduo em sociedade, submerso num jogo de perdas e ganhos, e, ao mesmo tempo, continuar vivendo em sociedade.

A decisão de continuar vivendo em sociedade, expressa historicamente por meio da ordem política, tem mudado profundamente na forma, levando em consideração, cada vez mais, o conjunto da sociedade assim como os indivíduos que a compõem.

Neste sentido, a separação entre a ordem dos indivíduos e a esfera social é também uma construção ideal do pensamento. Não há indivíduos sem sociedade. Parece mais plausível falar de sujeitos como uma categoria relacional e da individualidade como o conjunto de interesses, preferências, inclinações, gostos que compõem a percepção que os homens têm de si mesmos (self) e as opções que fazem nas relações interpessoais.

A referência a Freud neste trabalho justifica-se porque o tema do sujeito em psicanálise (Birman, 1991) é de ordem estritamente intersubjetiva. Diferentemente, a ciência política tem resistido, até muito recentemente a incorporar o plano do sujeito nas análises políticas (Landi, 1981; Giddens, 1984; Evers, 1984; Touraine, 1989; Habermas, 1984). Tal questão nos parece fundamental quando se trata de pensar formas de exercício da política no mundo moderno como viabilizadoras de melhores condições de existência para os homens. A ciência política tem procurado uma objetividade apoiada num modelo de conhecimento estrutural em que a política e as políticas públicas, especialmente, participam de uma lógica macropolítica alheia à atuação política de sujeitos dotados de vontade.

A idéia, presente ao longo deste livro, é a recorrência a 'sujeitos' como protagonistas às vezes conscientes, às vezes não, do acontecer político. Quanto a 
isso, 'a reprodução da democracia', questão que nos ocupa prioritariamente, está indissoluvelmente relacionada à 'constituição de sujeitos democráticos'. A referência a indivíduos ressalta o plano pessoal de satisfação de necessidades estritamente econômicas, encaminhadas à reprodução da vida, ou o consumo enquanto modo de vida na sociedade capitalista moderna, esquecendo que esses são também comportamentos sociais e culturais - especialmente o consumo -, para nos restringirmos ao mero ato de satisfação de uma necessidade material. Ao nos referirmos a 'sujeitos' estaremos lidando com um plano de análise no qual o reconhecimento do 'si mesmo' e a construção da própria identidade estão sempre relacionados aos outros.

A referência a sujeitos políticos não pode se desvencilhar da noção do 'sujeito'. A disposição para a ação social ou política é relacionada, neste sentido, ao preenchimento de necessidades de cunho estritamente psicológico, tais como: as respostas dos outros aos comportamentos políticos ou o reconhecimento do outro, emocional, afetivo, ideológico etc. Mas também à capacidade de postergar no tempo os benefícios resultantes da própria intervenção ou, dito de outra forma, à capacidade de antecipar resultados futuros.

Por um lado, o reconhecimento do outro, ainda que constitutivo da ordem social, como Freud (1957) afirma, pode não ter uma correspondência consciente da alteridade, quando se trata da atuação social e política. Por outro, a representação que se tem de 'si mesmo' (self) e do outro na ação política passa a ter uma conotação democrática quando a decisão de agir no plano político é um cálculo que necessariamente inclui o outro e onde, por sua vez, há certa confiabilidade da inclusão do self nos comportamentos externos ao mesmo.

$\mathrm{Na}$ dimensão do governo, o reconhecimento do outro (social) não significa a eliminação dos conflitos sociais. Pelo contrário, a existência dos mesmos poderia ser dirimida na arena da luta política dentro da diversidade de atores e interesses que esta comporta, desde que as regras de 'competição' democrática fossem suficientemente claras e explícitas para todos os atores sociais que participam do 'jogo democrático' sob a garantia de não exclusão, qualquer que seja a questão política em jogo. Tal possibilidade poderia provocar maior disposição ou encorajar amplos setores da sociedade a disputar, por meio da luta política, a 'publicização' da esfera pública.

Em sociedades extremamente desiguais, a constituição do selfé privilégio a ser usufruído por aqueles indivíduos que acederam à satisfação plena das necessidades e onde o 'outro' remete à quase metade da população desprovida do 
direito a se alimentar diariamente, ter um teto onde morar, ter direito ao trabalho e à saúde e a formar parte da sociedade, condições tais que por sua ausência colocam em questão a própria ordem civilizatória.

Em verdade, quando refletimos a respeito das políticas sociais, não estamos pensando exclusivamente em políticas de ordem redistributiva de bens de consumo social cujo locus administrativo é dado na esfera do Estado, ainda que essa seja uma primeira aproximação à compreensão do papel das políticas sociais. O que pretendemos focar é a constituição de agentes sociais em estreita relação com as políticas, o que implica definição das demandas referidas à política social e o fato de estes agentes serem 'sujeito' da política.

A idéia de constituição de sujeitos, em estreita relação com as políticas sociais, requer a existência prévia de direitos de cidadania universais legitimados pela ordem política. As políticas sociais passariam assim a adquirir, em nossa compreensão, o status do que Giddens ${ }^{10}$ denominou "políticas emancipatórias".

\section{Eqüidade / Justiça}

A questão da eqüidade é, sob a perspectiva aqui adotada, um componente principal da democracia. A eqüidade é embutida na idéia da cidadania, não como princípio, mas como o resultado das lutas sociais que transformaram a idéia de cidadania na obtenção de direitos concretos pela população. Os direitos civis, políticos e, por último, sociais constituíram os três momentos dos quais a cidadania se nutriu até alcançar um significado 'pleno', que, segundo Marshall, (1967) encontra-se bem distante daquele com o qual a concepção liberal lhe deu origem. A História pôs em movimento a idéia da cidadania, tendo redefinido assim sua própria noção. Daí que entre o princípio de igualdade formal e a noção de eqüidade se interpõe o reconhecimento da incapacidade de o mercado dar conta das desigualdades inerentes à sociedade.

As transformações históricas protagonizadas pelo movimento operário e pelos partidos de esquerda levaram a profundas reformas do capitalismo

\footnotetext{
10 "Defino política emancipatória como uma perspectiva genérica referente fundamentalmente à liberação de indivíduos e grupos dos entraves que afetam de maneira adversa suas chances de vida. As políticas emancipatórias envolvem dois elementos principais: o esforço de deixar para trás o passado, permitindo uma atitude de transformação em direção ao futuro; e o propósito de superação da dominação ilegítima de alguns indivíduos ou grupos sobre outros (...). As políticas emancipatórias objetivam reduzir ou eliminar exploração, desigualdades e opressões" (Giddens, 1991:212-213).
} 
(Przeworski, 1992), por meio da intervenção do Estado na economia e da regulação do mercado. De fato, os direitos sociais constituíram-se conquista das lutas operárias. A incorporação desses direitos mediante políticas sociais tiveram expressão nos Welfare States europeus em que a igualdade formal se aproximou da igualdade real. Assim, a eqüidade, como resultado, não é mais do que a maneira pela qual as modernas democracias sociais traduziram politicamente, sob o capitalismo, as desigualdades sociais em distribuição mais eqüitativa da riqueza e do bem-estar social.

A ampliação dos direitos sociais requer a progressiva intervenção do Estado por intermédio de políticas sociais. Por um lado, as implementadas a partir da década de 40 provocaram forte intervenção política do Estado e, portanto, uma 'mudança' na concepção liberal da democracia. A própria noção de democracia começa a ser relacionada à ampliação da participação social e política e às condições de vida capaz de proporcionar à população. Por outro, essas mesmas políticas sociais, como alternativa de implementação política das transformações, que atravessou a própria concepção de democracia, exigiram a presença reguladora do Estado na economia.

Uma parte do investimento estatal, o destinado às políticas sociais, passou a ser considerada compensatória da pobreza e investimento de capital, sem retorno de lucro. As políticas sociais funcionaram como salário indireto. Aquela parte do trabalho não retribuída pelo empregador e por este apropriada no processo de produção, coluna vertebral do processo de acumulação capitalista - a mais-valia -, passa a ser compensada pelo Estado por meio de bens de consumo social como aposentadoria, saúde, educação e moradia.

Uma das idéias que perpassou, na época, a teoria econômica keynesiana, foi a de que a ampliação do consumo era a chave para o crescimento econômico: os benefícios sociais, através das políticas sociais, têm como papel principal liberar uma parte considerável do salário, que já não precisa ser destinada à reprodução da força de trabalho e poderá ser destinada ao consumo. Neste sentido, o Estado teve também um importante papel, regulando o papel do mercado e agindo como planejador, investidor e direcionador do processo de acumulação capitalista. Além disso, uma forma de evitar modificações estruturais pode ser atenuando os efeitos do capitalismo sobre a classe trabalhadora.

De fato, o desgaste excessivo da força de trabalho inviabiliza um melhor aproveitamento da mesma no futuro, pela diminuição das capacidades necessárias para absorção de mudanças tecnológicas no processo produtivo e pela 
própria deterioração das condições de saúde do trabalhador. O Estado tem apoiado os investimentos privados e regulamentado os públicos, o que significa, também, assumir tarefas de controle e do equilíbrio do ciclo econômico.

Tal processo foi longo e complicado, na medida em que implicou alterações substantivas na economia capitalista e no modelo teórico-liberal que tinha sustentado até a década de 30 a não intervenção do Estado na economia e a própria noção de democracia como democracia liberal. Essas transformações que sofreu o capitalismo foram possíveis pelo grau de enfrentamento produzido pelas desigualdades sociais e pelo desmascaramento do discurso da igualdade entre os indivíduos que o liberalismo vinha exercitando desde os primórdios do capitalismo.

O processo teve origem e referência no campo da política. A teoria marxista da sociedade capitalista, junto às experiências socialistas de princípios do século, colocou a questão de uma maior 'eqüidade' - distribuição da riqueza como exigência das classes trabalhadoras européias em relação ao sistema econômico capitalista e sua contrapartida política à democracia liberal. A estruturação de fortes sindicatos nos setores vitais da economia, ligados aos partidos comunista e social-democrata - que adquiriram um peso crescente no eleitorado europeu -, abriu uma nova perspectiva para o capitalismo, via Welfare State.

Eqüidade e justiça social não são mais que as duas faces da mesma moeda. A eqüidade é agora uma condição da cidadania, redimensionada a partir das transformações do capitalismo, enquanto a justiça social diz respeito à incorporação da eqüidade como um novo código moral e ético das democracias modernas. A justiça social, ao mesmo tempo que dá conta da inclusão da 'igualdade real' na noção de cidadania, retraduz no plano formal uma nova ordenação jurídica que poderia ser considerada na ordem do Direito Social. Trata-se de uma esfera na qual se interpenetram instituições estatais sociais e que, conseqüentemente, não permite ser enquadrada nem no Direito Público nem no Privado.

É interessante notar que, apesar desse processo histórico, não há, no sistema capitalista como um todo, nenhuma necessidade indefectível de incorporar essas transformações. Pelo contrário, nos países em que não houve uma classe trabalhadora ou movimentos sociais que tenham acumulado importantes quotas de poder político, o capitalismo, como sistema econômico, tende a ser tanto ou mais predatório e reprodutor de enormes desigualdades sociais que quando de sua instalação originária. 
Neste sentido, seriam necessárias transformações na concepção e no exercício da política ao levarmos em consideração que, historicamente, a ação política tem tido um valor substantivo nas transformações do capitalismo, fazendo com que este se torne mais flexível. A incorporação da eqüidade na concepção da democracia e a maneira de implementá-la nos parece uma das questões centrais que hoje se colocam para o Brasil e outros países que atravessaram regimes autoritários e se encontram com enorme parcela da população no limite da pobreza absoluta. ${ }^{11}$

\section{Democracia e Reforma}

A democracia comporta reforma? Que capacidade tem a democracia de absorver reformas? Que tipo de reformas?

Em relação à primeira pergunta, se pensarmos a democracia apenas como um sistema de governo, acabaríamos confirmando necessariamente as premissas elaboradas sobre a teoria liberal no século XIX. Esta imaginou a democracia como o mais aperfeiçoado dos sistemas políticos: um sistema formal de igualdades e liberdades expressas politicamente mediante o voto de cidadãos livres e iguais; representado por partidos políticos competindo pela conquista do governo, por meio de eleições onde a decisão seria das maiorias, mas sem que isso significasse que as minorias tivessem de se sujeitar ao domínio despótico das maiorias. A teoria da democracia se colocava no contexto da economia capitalista e dentro de uma concepção do Estado na qual a economia e a política eram instâncias diferentes e separadas.

No entanto, o percurso histórico do exercício da democracia a partir das forças políticas e sociais fez com que sua práxis se distanciasse enormemente

11 Przeworski (1992:109) tem um enfoque diferente dessa questão: "Minha versão a respeito desta questão - as contradições inerentes ao capitalismo - defende que o capitalismo é irracional porque não pode acender a certas distribuições de bem-estar que são tecnicamente factíveis. Nós podemos ter meios tecnológicos e organizacionais de alimentar a todos na Terra e a vontade de fazê-lo; mas, ainda assim, ser incapazes de conseguir isto sob o capitalismo (...). Imagine uma economia na qual há dois agentes, P e W. Se os resultados não dependessem das taxas de retorno dos investimentos controlados por estes agentes, logo sob um dado estágio da tecnologia, toda a distribuição do bemestar se resume ao nível em que os resultados sejam acessíveis (...). Mas, sob o capitalismo, os resultados dependem das taxas de retorno dos investimentos. Se os capitalistas recebessem o retorno completo do capital e os trabalhadores, o retorno completo do trabalho, logo os recursos poderiam ser eficientemente alocados, e a distribuição dos ingressos poderia refletir a produtividade marginal dos fatores (...). Mas, se os capitalistas ou trabalhadores não têm o retorno completo, isto é, se a distribuição de ingressos difere do mercado competitivo, eles poderão retirar capital ou trabalho e os recursos seriam subutilizados. Sob o capitalismo, investimentos - capital e força de trabalho - propriedade privada e quem decide “se vão e como vão" utilizá-los são os próprios interessados". 
daquilo que a teoria clássica pensou como tal, ao mesmo tempo que o campo teórico da democracia, acrescido pelo pensamento marxista a respeito do Estado capitalista, procurou acompanhar as transformações histórico-políticas das democracias.

Acreditamos que as mudanças no campo teórico seguem um eixo que se estende da democracia formal à democracia substantiva, entendendo por democracia substantiva o seguimento teórico do processo histórico pelo qual agentes sociais conquistam efetiva cidadania, produzindo ruptura no 'discurso' democrático liberal. Afirmamos que o capitalismo per se não comporta reformas: quando estas ocorreram, tiveram origem no campo da política; foi a luta política nas democracias modernas que levou a mudanças no capitalismo.

A vitalidade da idéia da 'democracia' reside precisamente na sua indefinição teórica, na sua capacidade de se adequar às transformações históricas do agir político sem realizar-se em uma teoria 'acabada' da democracia. Neste sentido, a 'democracia' é uma construção histórico-política e também teórica. Se aceitarmos essa afirmação, concluiremos que a democracia, enquanto enunciado, comporta qualquer reforma.

Ao se indagar sobre a capacidade da democracia de absorver reformas e se a absorção (ou não) das reformas está diretamente relacionada ao grau de profundidade das mesmas, pode-se responder que, quando as reformas colocarem em perigo forças constituídas ou consolidadas no regime anterior, a dificuldade de sua implementação crescerá proporcionalmente à dimensão das mencionadas forças. Será necessário, portanto, um diagnóstico apurado ou o mapeamento das forças políticas e sociais envolvidas e não-envolvidas no processo de reforma, a relação de força entre elas e um cálculo estratégico que possibilite a acumulação de poder para a implementação das reformas. Mas seria possível chegar-se, talvez, a otimizar resultados com um investimento de tempo maior, se se trata de implementar reformas parciais.

Schmitter (1991b:4) discute a respeito da consolidação da democracia, mediante a constituição do que chama de "regimes parciais" e baseada na idéia gramsciana da construção de hegemonia por meio da "guerra de posições". Com o propósito de analisar esse processo - a consolidação da democracia pode ser proveitoso pensar a democracia moderna não como um regime, mas como um mix de regimes parciais, cada um articulando e governando um diferente conjunto de instituições.

Quaisquer que sejam a identidade e a significação dessas instituições, a consolidação do conjunto delas não acontece ao mesmo tempo. A lógica das mu- 
danças nos regimes obedece a certas prioridades. Algumas mudanças são intrínsecas à natureza genérica da democracia, como a institucionalização de um regime de controle civil sobre os militares ou acertos de negociação coletiva entre capital e trabalho, mas podem não ser implementadas no momento em que seria conveniente, pelo poder dos grupos de interesse que se veriam afetados. Essas diferenças nas seqüências nas quais distintos conjuntos de instituições são objeto de mudanças (ou não o são) podem ser cruciais para compreender os resultados eventuais.

A questão à qual Schmitter nos encaminha é que, em última instância, os regimes parciais que se estabeleçam vão prover importante informação a respeito do tipo de democracia que está sendo implementada. Ou seja, a luta dos diversos interesses em jogo, representados por uma ou outra proposta, as estratégias utilizadas e o timing para sua implementação vão possibilitar que reformas parciais ou setoriais sejam ou não efetivadas. Neste sentido, a democracia tem uma quota importante de "incerteza" (Przeworski, 1992; O’Donnell, 1988; Schmitter, 1991a), mas condicionada a uma relativa certeza. Esta, creio, seria dada pelo fato de que cidadãos munidos de uma 'cultura cívica' estarão em condições de aceitar que outros interesses de classe, pessoas ou grupos definam os cursos de ação política sempre que existam os canais e um tempo possível para a implementação dos próprios interesses. ${ }^{12}$

Acreditamos que a Reforma Sanitária e a luta em prol de sua implementação atualizam a disputa pelo predomínio da representação de interesses no setor saúde, por sua vez inscrito no contexto político mais amplo do processo de democratização. A Reforma Sanitária pode ser compreendida como um processo de estabelecimento de uma 'democracia parcial', ou como um 'regime parcial', em que a sua efetiva instituição e institucionalização atualizaria, na arena política da saúde, a condição de possibilidade do exercício da democracia tal como compreendida neste capítulo. Ou seja, não são condições suficientes para a consolidação da democracia o estabelecimento das intituições políticas, eleições periódicas e partidos políticos: a questão da eqüidade é principal para que a democracia se efetive. A Reforma Sanitária atualiza tal condição no campo da saúde.

Para discutir a última das perguntas aqui colocadas, acerca do tipo de reformas, acreditamos na necessidade de distinguir as transições do Leste euro-

12 A consolidação da democracia pode ser vista como um processo (o melhor dos processos) que torna esses procedimentos possíveis (...). Esta institucionaliza a incerteza em um subconjunto de papéis políticos e arenas políticas, enquanto institucionaliza a certeza em outras (Schmitter, 1991a:6). 
peu das transições na América Latina. Isso é importante porque, de maneira geral, quando se discute a questão das reformas, há uma assimilação entre estas e economia de mercado.

Reformas e liberalização do mercado são, a nosso ver, questões diferentes. Julgamos que não o são no caso dos países que estão transitando do socialismo para a democracia. A necessidade de liberalização política traz consigo, nos países do Leste, a recuperação do indivíduo não como sujeito, ainda que isso também esteja presente como reivindicação de um indivíduo diferenciado da sociedade, de uma ideologia de homogeneização social sustentada na ditadura do proletariado para a qual o indivíduo não tem valor. A recuperação do indivíduo pareceria trazer consigo a obtenção de um maior bem-estar econômico e condições de vida mais confortáveis; portanto, demandas pela ampliação do consumo e da propriedade privada. O indivíduo, como proprietário, alcança a sua realização pessoal pela diferença; assim, a posse de bens o diferenciará dos outros.

Não pretendemos, a respeito dessas observações, estabelecer juízos de valor. Em definitivo, qualquer forma de imposição política via autoritária, seja militar ou partidária, conduz a altos graus de compressão social que necessariamente encontram algum tipo de resolução com a desaparição do regime autoritário e da ideologia que o sustentou. Quando as barreiras de contenção se quebram, os movimentos sociais crescem e a constituição de processos de construção de identidades políticas se opera pela formação de um campo simbólico próprio e diverso daquele que tinha prevalecido em um momento anterior. Neste sentido, as reformas políticas nos países do Leste precisariam ser acompanhadas por reformas econômicas encaminhadas à liberalização da economia e, portanto, à constituição do mercado.

No caso da América Latina ocorre precisamente o contrário. Os regimes autoritários aprofundaram a acumulação capitalista (O’Donnell, 1975), o que significou, particularmente no caso do Brasil, um processo de aprofundamento das desigualdades sociais e da pobreza até um ponto que pode ser considerado intolerável para o conjunto da sociedade. Somado a isso, os estertores do regime autoritário foram acompanhados por uma crise econômica derivada da elevação internacional dos preços do petróleo, o que levou a uma elevação considerável da inflação e também a um empobrecimento das classes médias.

Desse modo, o que o processo de transição trouxe consigo foi o anseio por mudanças políticas que acabassem com o arrocho salarial e pudessem prover a distribuição mais justa da renda e menores desigualdades sociais. Assim, a 
construção de identidades políticas nos movimentos sociais que cresceram nesse período, questão que será tratada de maneira detalhada adiante, criou um campo simbólico baseado na justiça social. Por esse motivo, as reformas no campo da economia foram entendidas como a necessidade de controle sobre o capital monopolista e, portanto, sobre o lucro das empresas, a eliminação dos anéis burocráticos no interior do Estado (Cardoso, 1975), o crescimento do investimento em políticas sociais, a reforma agrária e o não-pagamento da dívida externa. As reformas tinham um conteúdo claro de socialização da economia.

Ao contrário, o que houve foram governos que, com plataformas e subterfúgios políticos pouco claros, venceram as eleições e pretenderam implantar, com maior ou menor êxito (Argentina, Chile, Brasil), reformas econômicas, no sentido de desregular a economia e cumprir as metas do FMI. Tais diretrizes foram seguidas não só em termos do pagamento da dívida externa, mas fundamentalmente em medidas de economia interna destinadas a controlar a inflação, dando um maior predomínio ao livre exercício das forças econômicas no mercado, abrindo as importações, restringindo a inversão interna, diminuindo o consumo e produzindo em definitivo a recessão e o crescimento da pobreza e das desigualdades sociais.

Isso leva a afirmar que as únicas reformas possíveis na América Latina são as postuladas pelo conjunto da sociedade e as de caráter progressivo, nas quais o mercado, ainda que mantido, seja regulado. É nesse contexto que se inscreve o processo da Reforma Sanitária no Brasil. 


\section{Processo de Reformulação do Setor Saúde: os atores, as estratégias e 0 papel dos organismos estatais}

O processo de transição à democracia trouxe a emergência de novos atores coletivos. Movimentos sociais proliferaram em todo o País, juntamente com as novas formas de exercício da política, ao mesmo tempo em que novos partidos faziam sua entrada na cena política nacional. Em cada canto do País as demandas por mudanças de liberalização política e de justiça social tomavam conta da sociedade.

No conjunto dos partidos de oposição, o 'resgate da dívida social' - resultante das políticas econômicas de alta concentração de renda do regime autoritário - era considerado o leitmotiv da construção da democracia. Um amplo debate perpassou a sociedade como um todo, no qual a possibilidade de reverter as enormes desigualdades sociais e a extrema extensão da pobreza se traduziu em propostas políticas que se concentraram na redefinição de políticas sociais. Estas foram vistas pelos partidos políticos de oposição como iniciadoras de um processo redistributivo de renda, caminho para a universalização de benefícios sociais para toda a população.

Nesse contexto inscreve-se o processo de reformulação do setor saúde que culminou com a proposta da Reforma Sanitária brasileira. Teve início em meados dos anos 70 e trouxe como liderança intelectual e política o autodenominado Movimento Sanitário. Tratava-se de um grupo restrito de intelectuais, médicos e lideranças políticas do setor saúde provenientes em sua maioria do Partido Comunista Brasileiro (PCB). Este exerceu papel destacado de oposição ao regime militar, assim como trajetória política própria na área da saúde.

O grupo influenciou fundamentalmente o âmbito acadêmico e pode ser considerado o mentor do processo de reformulação do setor. Recebeu influência do modelo da Reforma Sanitária italiana e desempenhou, também, impor- 
tante papel em organismos internacionais - como a Organização Pan-Americana da Saúde (OPS) - e em experiências alternativas de saúde implementadas em alguns municípios brasileiros na década de 70. A partir da abertura política e no período em que estava bem avançada a transição à democracia, passou a ocupar importantes espaços nos aparelhos institucionais de saúde no âmbito do governo federal, assim como nos governos estaduais e municipais.

A constituição do projeto reformador no âmago do Movimento Sanitário teve o primeiro impulso na década de 70 , com a criação dos departamentos de medicina preventiva nas faculdades ligadas à área, a partir dos quais se difundiu o pensamento crítico da saúde. Vinculado a esse percurso acadêmico, houve também avanços progressivos na implementação de políticas de saúde alternativas às impostas pelo regime militar, à medida que a transição à democracia adquiria um perfil mais nítido. Isso foi feito ou por meio de programas de extensão universitária, ou a partir das secretarias municipais de saúde de alguns estados onde se tinha certo controle político sobre as prefeituras, ou até mesmo por intermédio da ocupação de cargos técnico-administrativos no Ministério da Previdência Social.

O projeto reformador sustentou-se sobre uma ampla crítica ao modelo prevalecente, baseado no crescimento do setor privado à custa do setor público - o primeiro sendo financiado pelo segundo -, o que levou à falência, deterioração, ineficiência e crise do sistema público de saúde (Oliveira \& Teixeira, 1986).

Sem pretender refazer a história das propostas reformadoras na saúde, cabe assinalar alguns de seus principais momentos (Oliveira \& Fleury, 1986). Um deles, o Programa de Ações Integradas de Saúde, desenvolvido no interior da Previdência Social, propunha mudanças na relação entre o setor público/ privado, passando a privilegiar o financiamento do setor público. Pretendia também alterar o modelo médico-assistencial, promovendo uma relação integrada interna ao setor público e dando prioridade à assistência ambulatorial, estendendo também a cobertura e melhorando a qualidade dos serviços.

Ainda que se tratando de experiência parcial, já que seria implementada apenas em alguns estados e municípios, a assinatura dos convênios das Ações Integradas de Saúde (AIS), iniciada em 1982, previa de maneira incipiente a existência de instâncias de participação da população na gestão dos serviços de saúde, o que se constituiria também numa primeira tentativa de descentralização do Sistema de Saúde.

A partir de 1983, o Movimento Sanitário ampliou a proposta de reformulação do sistema de saúde, com a ocupação de espaços nas instituições 
estatais de saúde, com objetivo de produzir mudanças na política de saúde e tendo em vista que o próprio processo de transição à democracia o permitia. Tal crescimento adquiriu sua mais acabada expressão com a VIII Conferência Nacional de Saúde, em 1986, na qual se definiu o projeto da Reforma Sanitária brasileira, que introduziu mudanças no setor da saúde de forma a torná-lo democrático, acessível, universal e socialmente eqüitativo.

O projeto da Reforma Sanitária sustentou-se numa conceitualização da saúde ampliada, relacionada às condições gerais de vida como moradia, saneamento, alimentação, condições de trabalho, educação, lazer. A saúde, neste sentido, é definida como um 'direito do cidadão' e, conseqüentemente, um 'dever do Estado'. Ou seja, os cuidados à saúde ultrapassam o atendimento à doença para se estenderem também à prevenção e à melhoria das condições de vida geradoras de doenças.

Para que isso fosse efetivado, fizeram-se necessárias transformações nas políticas de saúde, tendo sido encaminhadas pela proposta os seguintes pontos:

- criação de um sistema único de saúde com notável predomínio do setor público;

- descentralização do sistema e hierarquização das unidades de atenção à saúde;

- participação e controle da população na reorganização dos serviços;

- readequação financeira do setor.

O notório retrocesso político após o primeiro ano de governo da Nova República imprimiu considerável estagnação, em âmbito governamental, no ritmo da implementação do processo de reformulação do setor, se comparado com os notáveis avanços conseguidos na definição da reforma do sistema na VIII Conferência Nacional de Saúde.

\section{A Comissão Nacional da Reforma Sanitária}

A partir da aprovação, na VIII Conferência, do projeto da Reforma Sanitária, dar-se-ia então continuidade às resoluções emanadas desta por meio da formação da Comissão Nacional da Reforma Sanitária, que teria em suas mãos o processo de implementação do projeto na esfera do governo. Paralelamente, criou-se a Plenária Nacional de Entidades de Saúde, cuja finalidade era dar 
continuidade à articulação dos organismos da sociedade civil que participaram da VIII Conferência e elaborar um projeto constitucional para ser apresentado no processo constituinte.

A Comissão Nacional da Reforma Sanitária - proposta pelo Ministério da Saúde como desdobramento da VIII Conferência Nacional de Saúde - previa uma composição paritária de entidades do governo e da sociedade. No entanto, sua composição não correspondeu ao peso real das associações da sociedade civil, ficando estas em minoria em relação aos organismos estatais e privados do setor saúde.

A Comissão foi aprovada e constituída por 22 representantes, dos quais somente seis eram representantes de organismos populares: a Central Única dos Trabalhadores (CUT), a Confederação Nacional dos Trabalhadores (CGT), a Confederação dos Trabalhadores da Agricultura (Contag), a Confederação Nacional dos Médicos (FNM) e a Confederação Nacional de Associações de Moradores (Conam). Os outros 16 membros pertenciam a organismos governamentais, a parlamentares, a centrais patronais e a prestadores privados de serviços de saúde.

A composição da Comissão atualizou, desde o início, a forma de preservação do Estado perante políticas oriundas das entidades organizadas da sociedade, além de alternativas ao modelo hegemônico no setor saúde. A Comissão Nacional da Reforma Sanitária pode se constituir em um bom exemplo de como o Estado filtra demandas da sociedade, por meio do exercício da "seletividade estrutural" (Offe, 1984). Esse mecanismo não se operou pelo veto de algumas temáticas e a seleção de outras, mas pelo procedimento utilizado por organismos estatais para compor a Comissão.

A partir da formação da concessão produziu-se um deslocamento da luta que acontecia no âmbito social e que culminou com uma proposta de amplo alcance e consenso social para o interior dos organismos estatais de saúde. A disputa pela implantação da Reforma Sanitária passou a se dar no terreno dos enfrentamentos políticos das diversas facções da tecnoburocracia do setor e a propósito da execução dos avanços operacionais previstos pelo projeto.

\section{Os Percalços no Processo da Reforma}

Esses enfrentamentos, ocorridos no Ministério de Saúde e mais fortemente na Previdência Social, estiveram permeados pelas próprias lógicas do setor 
público, portanto, limitados pela relação de forças no interior dos aparelhos de Estado, afeiçoadas ao clientelismo político, à política de favores pessoais e às rotinas burocráticas como uma maneira de impedir a implantação de políticas inovadoras nas práticas institucionais.

As tentativas de transformação do sistema de saúde mediante a ocupação de espaços nesses ministérios não conseguiram produzir avanços continuados na implantação da Reforma. Paulatinamente, os representantes do Movimento Sanitário foram sendo demitidos de seus cargos. ${ }^{13}$

Quanto à efetiva implantação da Reforma, em 1987, aprovou-se o Decreto pelo qual se criou o Sistema Unificado e Descentralizado de Saúde (Suds), que contemplava o encurtamento da máquina previdenciária de nível estadual; a transferência dos serviços de saúde e dos recursos financeiros para os estados e municípios; o estabelecimento de um gestor único de saúde para cada esfera de governo e a transferência para os níveis estadual e municipal dos instrumentos de controle sobre o setor privado (Escorel, 1992). No entanto, a implementação dos Suds acabou decepada no que tinha de transformação substantiva do sistema de saúde, tendo ocorrido apenas algumas mudanças administrativas no setor.

A política de saúde do governo da Nova República acompanhou os percalços da transição, caracterizando-se por idas e vindas no processo de descentralização, na integração interinstitucional e no que diz respeito ao privilegiamento do setor público. Por meio de mecanismos políticos, contábeis e burocráticos no Inamps e no Ministério da Saúde, criaram-se obstáculos à implementação dos SUS, dentre os quais o que mais se notabilizou foi o desaparecimento dos recursos nos meandros das máquinas federais, estaduais e municipais. Certamente, as destinatárias finais do financiamento do setor - as unidades locais de saúde - viveram em permanente crise por não terem condições de pagar aos profissionais de saúde, bem como pela falta de instrumental, manutenção dos equipamentos e dos medicamentos.

Os percalços à implantação da Reforma geraram uma grande desconfiança na população em relação ao setor público da saúde. A situação foi muito

13 Na Previdência Social, a condução comprometida com as reformas manteve-se até meados de 1988, quando da negociação do mandato presidencial e do regime de governo. A partir de 1988, nenhum representante do Movimento Sanitário permaneceu em cargos da direção do Inamps (Escorel, 1992:23). 
bem aproveitada pelo setor privado, que cresceu consideravelmente no período, sobretudo os seguros privados de saúde. Em 1989, aproximadamente um quarto da população - 32 milhões de pessoas - estava coberto por seguros privados, os quais movimentavam em torno de 2,5 bilhões de dólares, cerca de 19\% do gasto total com saúde (Revista Conjuntura em Saúde, jul. 1992).

A Plenária Nacional de Entidades de Saúde teve significativos avanços em termos de articulação de um movimento social de caráter nacional em torno da questão da saúde, conseguindo plasmar na Constituição Nacional os princípios da Reforma Sanitária. A Plenária foi constituída em meados de 1987, alimentada pelas Plenárias Estaduais criadas imediatamente após a VIII Conferência Nacional de Saúde. Compunha-se de entidades representativas das seguintes forças:

- Movimento Popular em Saúde - Confederação Nacional de Associação de Moradores (Conam) e federações estaduais;

- movimento sindical - Central Única dos Trabalhadores (CUT), Confederação Nacional dos Trabalhadores (CGT), Confederação dos Trabalhadores da Agricultura (Contag);

- partidos políticos de esquerda - Partido Comunista Brasileiro (PCB), Partido Comunista do Brasil (PC do B), Partido dos Trabalhadores (PT), Partido Socialista Brasileiro (PSB), Partido Democrático Trabalhista (PDT);

- profissionais de saúde, representantes do Movimento Sanitário e a academia - Centro Brasileiro de Estudos em Saúde (Cebes), Associação Brasileira de Pós-Graduação em Saúde Coletiva (Abrasco), União Nacional dos Estudantes (UNE) etc.;

- entidades estaduais e municipais da saúde favoráveis à Reforma - Conselho Nacional dos Secretários de Saúde (Conass), Conselho Nacional dos Secretários Municipais de Saúde (Conasems).

De fato, a articulação e organização das forças populares na Plenária Nacional possibilitou que o capítulo da saúde na Constituição contemplasse o direito universal à saúde e a criação de um sistema único de saúde, descentralizado, acessível e democrático. Incluiu a complementação das necessidades de saúde da população com serviços preferencialmente filantrópicos e estabeleceu com o setor privado, em geral, contratos regidos pelas normas de direito público. Assim, enquanto a Reforma Sanitária era incorporada à Constituição no 
capítulo referente à saúde, paradoxalmente a implementação do Suds atravessava o momento de maior retrocesso, que, por sua vez, repercutiu fortemente no Movimento Popular em Saúde, como veremos adiante.

\section{A Construção de uma Abordagem Conceitual}

Ao considerarmos a Reforma Sanitária como uma particular política de saúde, a estamos incluindo dentro do campo mais amplo das políticas sociais no contexto de democratização. Neste sentido, o que nos interessa por ora é discutir as diversas formulações teóricas sobre política social, de maneira que estas contribuam para desvendar o processo da Reforma Sanitária brasileira, especificamente no tocante à sua implementação - iniciada em 1987 com a reforma administrativa do sistema de saúde e a criação do Suds -, que atravessou grandes empecilhos para se efetivar. A Reforma Sanitária coloca-nos perante questões que remetem ao campo teórico das relações entre o cidadão e o Estado no direcionamento e na implantação de políticas sociais em um contexo de construção/consolidação da democracia.

No interior da ciência política, desde o século XVIII e sob diferentes perspectivas a política social constituiu um âmbito de reflexão no sentido de problematizar se o Estado deveria intervir ou não para suprir ou remediar as carências ocasionadas pela pobreza; se a pobreza deveria ser atribuída à incapacidade das pessoas ou se, pelo contrário, o movimento natural da economia e suas flutuações é que geravam pobreza.

Já no século XIX vários pensadores se preocuparam em discutir o papel que caberia ao Estado perante o processo de industrialização capitalista, que destituiu da proteção social os milhares de trabalhadores que abandonavam as formas feudais agrárias de produção para se constituírem trabalhadores livres. No liberalismo clássico ou no liberalismo conservador de nossos dias, entendese que o Estado não deve intervir na economia, nem para corrigir desigualdades sociais, restringindo-se à sua expressão mínima - as políticas sociais.

Outras correntes de pensamento que se distanciam do liberalismo, aproximando-se de propostas social-democratas, defendem a incorporação, por parte do Estado, de políticas regulatórias em relação ao mercado para contrabalançar os efeitos nocivos do mesmo, principalmente o desemprego, e prover de seguridade social as camadas sociais desprotegidas, eliminando as grandes desigualdades sociais. Expoentes dessa tendência são a teoria econômica keynesiana 
e o Plano Beveridge, enquanto proposta política concreta para o Estado fornecer seguridade social a todos os cidadãos.

Já no caso do marxismo clássico, nega-se que o Estado capitalista possa prover bem-estar às classes trabalhadoras ou avaliar os males que ele mesmo cria, pois isso significaria a existência de valores contrários frontalmente às instituições capitalistas. No entanto, é de salientar o reconhecimento da proteção da mão-de-obra por parte do Estado no tratamento que Marx dá à diminuição da jornada de trabalho na Inglaterra. ${ }^{14}$

Este tem sido o ponto de partida para o pensamento das políticas sociais, embora diferentes teorias ou abordagens teóricas das ciências políticas tenham tido apreciações próprias a respeito do domínio da política social.

Para o pluralismo, as políticas sociais são entendidas como conseqüência da existência de diversos grupos de interesse presentes na sociedade, que, por atuarem numa determinada arena política, influenciam a tomada de decisões a respeito das políticas sociais. Na concepção 'elitista', são os administradores (policy makers) que interagem no interior do Estado e dão substância concreta tanto às iniciativas como à implantação das políticas sociais. A Teoria da Convergência, que constitui uma variante do modelo funcionalista, entende que as políticas sociais são uma resultante do desenvolvimento econômico e industrial e que em torno deste a estrutura social como um todo se integra funcionalmente.

Nas abordagens mais recentes da teoria marxista há, em alguns casos, uma preocupação expressa pelas políticas sociais que se sustentam em estudos sobre a complexidade do Estado capitalista de nosso tempo. Em outros, a preocupação pela política social não se manifesta explicitamente como no caso de Poulantzas (1980), que, no entanto, se refere a elas ainda que de maneira não explícita, ao analisar o papel atual do Estado.

Diante da diversidade de visões e definições da política social, procuraremos aqui incorporar a riqueza e os diferentes ângulos de algumas dessas abordagens teóricas, buscando um marco conceitual que, sem perder de vista a teoria marxista, possa nos encaminhar a uma visão mais ampla no que diz respeito às políticas sociais e que evite tanto a pura determinação estrutural quanto o voluntarismo dos atores.

\footnotetext{
14 "sobre a constante pressão dos operários agindo por fora, nunca essa intervenção dar-se-ia. Em todo caso, este resultado não teria sido alcançado por meio de convênios privados entre os operários e os capitalistas” (Marx, 1978a:96).
} 
Denominaremos esse marco conceitual, que integra elementos da teoria marxista e da teoria weberiana das instituições, de 'enfoque integrado das políticas sociais', identificado com a ótica de Offe (1984), mas complementado por algumas contribuições da bibliografia latino-americana sobre o tema.

Para Offe (1984), existem dois planos de análise da política social, um estrutural e um singular, articulados mediante relações que se estabelecem no plano específico do político. No plano estrutural, as políticas sociais estão ligadas ao Estado capitalista e às suas determinações estruturais. No singular, são consideradas pelas peculiaridades que as distinguem de outras políticas, e sua singularidade pode ser captada por meio da pesquisa empírica concentrada em dois eixos básicos: a evolução, modificações e inovações de uma política social dada; e a relação entre estratégias de racionalização administrativa e a implementação de inovações políticas.

No plano estrutural, a política social cria condições socioestruturais para que o trabalho assalariado funcione como tal. Por meio da política social, o Estado vai regulamentar quem participa ou não do mercado de trabalho. Para isso, precisa organizar e sancionar as formas de existência externas ao mercado: pessoas que pela idade avançada não estejam mais em condições de trabalhar passam a ser atendidas pelo sistema previdenciário; pessoas que não estejam em boas condições de saúde ficam sob a responsabilidade do sistema de saúde; crianças e jovens são atendidos pelo sistema de educação. Neste sentido, a política social responde às reivindicações da classe operária, mas também a constitui, na medida em que:

- integra a força de trabalho ao mercado;

- as diversas instituições de previdência, saúde, educação e habitacionais exercem o controle da força de trabalho e socializam os custos do desgaste da mesma;

- regulamenta quantitativamente a relação entre oferta e demanda no mercado de trabalho.

Como se poderia compreender a evolução, as modificações e inovações no plano singular do estudo das políticas sociais? Diante de uma visão marxista de cunho estrutural funcionalista, que explica as políticas sociais ou porque servem ao processo de acumulação capitalista, ou porque possibilitam que o Estado se legitime junto às exigências da classe operária organizada, Offe afirma que as inovações nessa área obedecem à compatibilização de estratégias que se dão na esfera do político. 
Assim, o Estado reage tanto às 'exigências' como às 'necessidades', de acordo com as instituições políticas (adequando-as, modernizando-as etc.) e as relações de força existentes na sociedade, canalizadas por essas instituições. A política social não está a serviço das necessidades ou exigências de qualquer classe, mas reage aos problemas estruturais do aparelho estatal de dominação e de prestação de serviços. Se a afirmação anterior é verdadeira, as inovações na política social criam condições de interações conflitivas entre grupos e classes sociais e seus resultados são imprevisíveis ou ambivalentes.

\section{Os Aportes da Bibliografia Latino-Americana na Abordagem Conceitual da Reforma Sanitária}

Passamos a destacar algumas contribuições da bibliografia latino-americana, que, acreditamos, contêm idéias-chave a serem incorporadas e articuladas nesta análise. Tal incorporação sustenta-se na necessidade de, em nosso ponto de vista, enfatizar o papel que a luta política, nas suas diversas formas, e a relação de forças entre grupos sociais e classes têm nos processos de formulação e implantação das políticas sociais.

Uma dessas contribuições (Diniz, 1978) destaca na análise das relações entre Estado e sociedade o papel dos 'atores sociais', mas sem abandonar a perspectiva dos limites dentro dos quais esses atores agem, as determinações estruturais do Estado capitalista. Aponta o papel predominante que o Estado tem na bibliografia latino-americana, deixando num lugar subordinado da análise os fundamentos sociais da política.

Em outras palavras, a primazia atribuída ao Estado no processo de desenvolvimento capitalista, ainda que esta seja incontestável, descaracterizou a sociedade civil como geradora também de processos com dinamismo próprio. Por isso, defende-se a necessidade de captar essa articulação de interesses, suas conexões com agências governamentais e técnicos localizados em pontos estratégi$\cos$ da burocracia pública. Distingue-se entre uma fase puramente decisória das políticas e outra de implementação, chamando atenção para a distância entre a decisão e a aplicação.

É aí precisamente que se faz sentir o peso dos diversos interesses em jogo. Há medidas que são aprovadas e cuja execução é bloqueada ou pela burocracia ou pelo poder de veto do grupo diretamente afetado. Trata-se de "levar em conta a um só tempo as determinações estruturais e o peso das opções feitas 
por atores ou grupos de atores que, ao escolherem uma alternativa ou outra, atualizam as possibilidades estruturais" (Diniz, 1978:25).

A idéia introduzida por Santos (1979) sobre a complexificação do social refere-se ao processo de diferenciação social e de multiplicação organizacional que se operou nas sociedades nas últimas décadas. Surgem novos grupos com grande heterogeneidade como resultado de novos papéis, ocupações e posições sociais, sendo difícil reconhecer nessa diversidade classes sociais mais homogêneas. Ao mesmo tempo, o processo é acompanhado também pelo aumento de uma multiplicidade de organizações que cumprem o papel de mediatizar a ação desses movimentos e grupos sociais.

Finalmente, Oszlak \& O’Donnell (1976) analisam as políticas sociais a partir de uma perspetiva centrada na recuperação da 'história dos problemas sociais' ou demandas políticas e da 'história das políticas'. Considerando que as políticas sociais ocorrem no cerne do Estado, em sua 'ossatura' institucional, caberia interrogar como se retraduzem exigências sociais em problemas e, por sua vez, estes em resposta do Estado, mediante políticas específicas.

Há uma seletividade das instituições políticas pela qual determinadas demandas se traduzem em problemas, e conseqüentemente em políticas, e que opera nos dois planos da política social. De um lado, a tematização ou exclusão de questões refere-se ao plano singular da política social; tais procedimentos, de outro, operam no plano estrutural, não deixando que determinadas questões possam ameaçar a própria existência do Estado como Estado capitalista.

Trata-se, para Offe (1984), de uma seletividade estrutural desse mesmo Estado capitalista. Um sistema de filtros vinculados a interesses de classes não visíveis faz com que determinadas questões sejam excluídas pelas instituições do Estado, enquanto outras são transformadas (de substanciais em menos relevantes), e algumas outras, ainda, favorecidas.

Hirsch (1977), da mesma forma, trata desse sistema de barreiras e filtros que opera na órbita do Estado, transformando exigências políticas em uma agenda viável de problemas e questões. Acrescenta a esse tratamento quatro modalidades ou formas em que funciona, na prática, a seletividade:

- as determinações fundamentais de desenvolvimento social não são objeto de decisões políticas;

- o limite dos recursos materiais do Estado é dado pelo lucro do capital; 
- a seletividade do sistema político se coloca na repressão física e na integração ideológica.

- e, de maneira principal, as exigências que penetram nos aparelhos de Estado são tratadas de maneira funcional por burocracias que atuam autonomamente e que têm competências, clientelas e percepções próprias dos problemas.

Em relação a como se opera essa seleção, Oszlak \& O’Donnell (1976) chamam a atenção para um estudo não só das transformações do Estado capitalista e suas modalidades de relacionamento com a sociedade civil, mas, de maneira mais específica, também de como o Estado opera para transformar questões sociais em políticas concretas. No caso, se trataria de recuperar o processo histórico tanto dos problemas como das políticas.

Articulando agora as contribuições discutidas anteriormente com a proposta elaborada por Offe, as proposições dos autores discutidos anteriormente, teremos o seguinte quadro sinóptico para a análise da Reforma Sanitária brasileira.

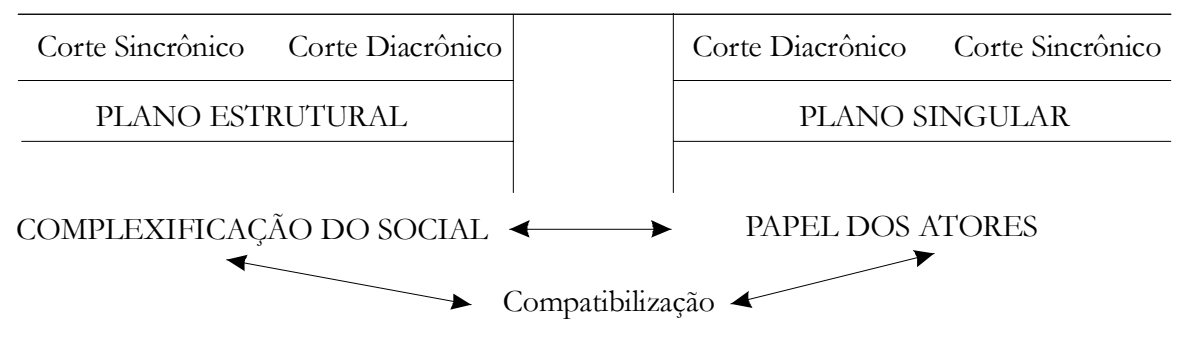

A complexificação do social, proveniente do enfoque de análise pluralista, seria articulada no plano de análise estrutural, possibilitando complexificar a análise marxista de classes sociais, pois no estágio atual do processo de acumulação capitalista não podemos localizar com nitidez as duas classes fundamentais e antagônicas - burguesia e proletariado.

Esse processo de estratificação dificulta tanto a delimitação objetiva de classe como a própria identidade de classe. Grupos sociais que se superpõem à estrutura produtiva, assim como movimentos sociais urbanos que surgem na esfera da reprodução da força de trabalho, via consumo de bens coletivos proporcionados pelo Estado por meio de políticas sociais, têm formas organizativas próprias expressando demandas sociais. 
Nessa diversificação social sustentam-se os comportamentos dos atores políticos, os quais são fundamentais para compreender inovações políticas. Paralelamente, esses atores podem assumir interesses diversos - de classe, corporativos, de grupos, individuais - que podem ou não se exprimir ideologicamente. $\mathrm{O}$ procedimento de adequação de estratégias políticas aos processos de racionalização administrativa e/ou inovações políticas, assim como o direcionamento das mesmas é gerado pelo desempenho dos atores políticos.

Por último, incorporar à análise a história das demandas sociais e das políticas sociais coloca-nos diante da necessidade de realizar um corte diacrônico (histórico) tanto no plano da análise estrutural quanto no plano singular das políticas sociais. Isso complementaria a análise de Offe, na medida em que este autor só fazia referência à importância de se realizar um corte diacrônico no plano 'singular' das políticas sociais que reconstrua a 'história dos efeitos' das políticas sociais.

\section{Observações Resultantes do Enfoque Metodológico Adotado}

No marco da discussão teórica, a Reforma Sanitária, como política social, foi uma proposta surgida de um movimento social que, no cerne do processo de transição à democracia, teve a capacidade de se articular.. Ainda que se tenha conseguido uma proposta acabada de reformulação do sistema de saúde sancionada na Constituição, há grandes dificuldades para implementá-la. Diversos interesses presentes tanto na sociedade como no Estado oferecem resistências, utilizando desde mecanismos de veto à política até tentativas de modificá-la substancialmente.

Offe (1984) menciona algumas dificuldades, dilemas e possíveis soluções ao tratar das inovações sociopolíticas e de racionalização administrativa experimentadas na Alemanha com a crise do Welfare State, que puderam colaborar para evitar os vetos à Reforma Sanitária. A Social Democracia alemã não poupou recursos fiscais destinados a políticas sociais.

No plano das inovações sociopolíticas procurou-se, então, aumentar a eficiência das políticas sociais; especificamente em relação à política de saúde, uma das soluções encontradas foi por intermédio de estratégias preventivas, buscando melhorar as condições de trabalho e de vida da população.

As dificuldades e resistências assinaladas anteriormente podem nos servir de referência ao aprofundarmos os problemas concretos que a implementação da Reforma Sanitária traz no caso do Brasil, sem significar que seja viável a 
reprodução das experiências realizadas nos países com democracias avançadas; estas nos ajudam a pensar as questões políticas e econômicas relacionadas a processos de reformas ou inovações sociopolíticas, que passam então a adquirir importância decisiva na consolidação da democracia.

Um dos problemas atuais de maior complexidade para o estabelecimento da democracia é a representação dos interesses ‘subalternos' nas agendas políticas ou, mais precisamente, a existência de espaços para que isso aconteça no interior das políticas sociais. Ainda que, hoje, nos países de capitalismo avançado, o Estado não possa incorporar demandas sociais como em décadas ante-riores, diversos interesses, de maneira institucionalizada ou não, se fazem representar.

No meio de uma profunda crise do Welfare State, os sindicatos e outras organizações sentam-se à mesa de negociações participando da formulação e implementação de políticas sociais. No Brasil, onde não houve até recentemente sistema político de corte liberal-democrata, o reconhecimento de direitos de cidadania e, especificamente, do direito de usufruir de um mínimo de bemestar foi bastante tolido. Tal situação é agravada pela implantação de políticas econômicas de ajuste à crise, que trouxeram cortes nos gastos destinados às políticas sociais, intensificando ainda mais o problema estrutural da miséria. Especificamente no setor saúde, os mecanismos de ajuste à crise foram: diminuir os recursos do Tesouro, aumentar as contribuições de empregados e empregadores e criar novos fundos sociais, que, em lugar de serem destinados a financiar ações para os setores sociais, se destinaram a suprir a crise fiscal.

Ao compreender o processo de democratização do setor saúde como a constituição de um regime de democratização parcial, os percalços no andamento da Reforma Sanitária remetem a dificuldades mais gerais, que dizem respeito ao próprio processo de consolidação da democracia. Desse modo, a Reforma Sanitária tem convivido com uma permanente falta de recursos, o que afetou profundamente o setor público da saúde, alterando a credibilidade dos usuários e seus movimentos sociais organizados. 


\section{Os Movimentos Sociais em Saúde: questões teórico-metodológicas para sua abordagem}

O Movimento Social em Saúde é formado pelo Movimento Popular em Saúde e pelo Movimento Médico. Ainda que se caracterizem pelas profundas diferenças na composição, institucionalização, grau de articulação, problematização das questões e eixos de atuação, existem importantes elos entre ambos.

O final da década de 70 foi um momento sui generis na política brasileira no que se relaciona ao papel da sociedade civil, com o surgimento de diversas entidades em diversos setores da vida social. Um movimento febril de agitação e oposição política atravessou toda a sociedade, promovendo um amplo debate e mobilização social em prol do fim do regime autoritário e da democratização do País.

A ditadura militar, em processo singular, acompanhou as propostas de abertura política. De uma parte, as Forças Armadas assumiram a obrigação de tutelar um processo que, se fosse além do 'razoável', poderia colocar em xeque o próprio papel e a relevância das mesmas no contexto político brasileiro, assim como os parâmetros de sociedade e Estado, cuja sobrevivência justificara a intervenção militar na década de 60 .

A abertura 'lenta, gradual e segura' foi a estratégia escolhida pelas direções militares, que viam no endurecimento e na repressão - posição representada por uma parte dos altos comandos das mesmas - o caminho mais curto para a radicalização da sociedade, com a conseqüente ameaça aos objetivos estratégicos das Forças Armadas.

Enquanto isso, em reuniões e apreciações das cúpulas militares, era medido e ponderado o descontentamento da sociedade brasileira, que ia crescendo proporcionalmente à dimensão da crise econômica pós-milagre e às dificulda- 
des de expressão política. À medida que as contradições começavam a se colocar no interior das Forças Armadas, a sociedade ganhava espaço e força nas reivindicações por mudanças políticas. Nesse contexto, o Movimento Social em Saúde se originou e teve presença marcante em duas vertentes: o Movimento Popular em Saúde e o Movimento Médico.

\section{O Movimento Popular em Saúde}

Os movimentos populares em saúde se originaram nos bairros pobres das periferias das grandes cidades e/ou nas favelas localizadas nos grandes centro urbano-industriais. ${ }^{15}$ Tratou-se de uma primeira fase no surgimento desses movimentos, que começaram a proliferar na década de 70 , que aqui será denominada 'fase reivindicativa'. Os moradores desses bairros se agruparam ao redor de associações comunitárias buscando alguma forma de organização primária em torno de reivindicações por melhores condições de vida, saneamento, postos de saúde, água, esgotos, moradia, transportes etc.

Essas formas de associação possibilitaram criar laços de solidariedade e de organização. Isso levou à eleição de representantes para a condução das associações de moradores, que exerceram papel principal no encaminhamento das demandas ao Estado.

O Movimento Popular em Saúde teve uma marcante presença de médicos, profissionais e agentes de saúde. Esses profissionais exercitaram um certo paternalismo, ao mesmo tempo que políticos 'fisiologistas' estabeleciam bases para a obtenção de vetos em troca de algumas melhorias, como a instalação de bicas ou de luz em algumas favelas.

Cabe assinalar que nenhuma relação existia entre esses profissionais de saúde, que na década de 70 desenvolveram militância política por meio da prática profissional nos bairros carentes das grandes metrópoles. Sua intenção era colaborar para a organização política das mesmas, enquanto os políticos fisiologistas operavam por meio de máquinas político-partidárias - caso do chaguismo, no Rio de Janeiro -, com finalidade exclusivamente eleitoral.

Tratou-se de um momento inicial na constituição do Movimento Popular em Saúde em torno de reivindicações 'pontuais', nas quais atribuía-se ao Estado a responsabilidade pela falta de assistência médica, postos de saúde e hospitais e

\footnotetext{
A trajetória histórica do Movimento Popular em Saúde e do Movimento Médico no período de estudo será tratada mais detidamente na Parte II.
} 
conseqüentemente pela não-resolução de tais problemas. Esse momento está intimamente ligado à agitação política presente na sociedade e à atividade desenvolvida na busca de liberdades políticas e de arrocho dos problemas de carência social resultante do arrocho salarial do regime autoritário.

Essa efervescência política se estendeu até a década de 80, com a campanha pelas eleições diretas para Presidente da República. Identificamos este momento com uma segunda fase na existência dos movimentos populares, na qual se mantiveram os mesmos eixos reivindicativos, as associações de moradores dos diferentes bairros conseguiram se articular para a discussão dos problemas comuns, fazer uma leitura política dos mesmos e propor uma atuação destinada a interferir nas soluções que o Estado viesse prover. A esta fase denominaremos 'politização do Movimento Popular em Saúde'. As associações organizaram-se em torno de federações de associações de moradores nacionais e estaduais, reunindo-se periodicamente, elegendo suas direções e se organizando em seções ou departamentos de saúde, terras e moradia, educação etc.

Os momentos mais notáveis na organização e mobilização do Movimento Popular em Saúde conduzido pelas federações estão associados às situações nas quais o quadro sanitário da população tornou-se crítico, como aconteceu com a epidemia de dengue. Ainda que tenham existido outros momentos críticos, como a epidemia de meningite, no início da década de 70, o movimento não alcançara uma expressão própria que lhe permitisse irromper na cena nacional.

A luta política para erradicar a epidemia de dengue foi uma conquista que marcou o Movimento Popular em Saúde. Diversas manifestações populares tiveram ampla difusão nos meios de comunicação, em razão da gravidade e extensão da epidemia e do caráter das associações do movimento popular, que conseguiram fechar as estradas que interligam os estados mais importantes do País. Os resultados da ação empreendida tiveram amplo alcance, seja no interior do movimento popular seja no tocante às medidas implementadas pelo Estado para combater a epidemia.

Podemos depreender que a segunda fase, entrelaçada à primeira, se caracterizou por um continuum no crescimento da ação coletiva do movimento e atravessou os primeiros dois anos da Nova República, até 1986, quando as expectativas políticas desapareceram e a conjuntura adquiriu um nítido caráter de estagnação. Nenhum dos grandes males políticos que assolavam o País - a corrupção, o clientelismo, a política de favores pessoais, a impunidade, a pobreza calamitosa de mais da metade da população - foi enfrentado ou combatido 
pelo então governo. A retomada da inflação, os quadros políticos (civis) da ditadura militar ocupando mais espaços-chave no governo, tudo acobertado por um discurso de cunho transformador, produziram um enorme descrédito não somente quanto às possibilidades de mudança, mas o que é pior, quanto à convicção da população de que a ação e a mobilização políticas eram suficientes para alterar o quadro.

Finalmente, a terceira fase do Movimento Popular em Saúde pode ser caracterizada como de 'acesso a formas orgânicas da política' ou de 'institucionalização'. Está relacionada à formação da Plenária Nacional de Saúde, movimento que teve importância central na formação das Plenárias Estaduais e Nacionais, que, por sua vez, tiveram papel decisivo na elaboração da Constituição de 1988.

Precisamente no momento em que o Movimento Popular em Saúde esteve mais próximo das decisões políticas substantivas, a ausência de maturidade para absorver a institucionalização como uma exigência do processo político no setor se traduziu em cisão interna. Isso se deu como resultado das diferenças políticas no interior do movimento, que trouxe como conseqüência o descenso na atuação do mesmo.

Neste sentido, identificamos a presença de duas grandes facções. Uma delas é mais crítica e radical em sua visão de Estado, referindo-se a ele como um espaço exclusivo das classes dominantes. Tem um discurso anti-Estado, rejeita qualquer ação estatal e considera que se houver medidas que favoreçam as classes mais pobres, terão por objetivo o controle social; assume, conseqüentemente, uma postura mais 'autonomista' e de distanciamento da máquina estatal. A outra facção, ainda que caracterize o Estado como domínio da burguesia, não acredita que este seja tão monolítico a ponto de não haver em seu interior fraturas pelas quais seja possível pressionar e negociar a obtenção de conquistas sociais em saúde.

No processo mais amplo em torno da discussão da Constituição apareceram as diferenças políticas entre as duas facções. A luta ideológica interna do movimento teve conseqüências singulares em relação à ação política coletiva. A atuação política 'para fora', que havia caracterizado o movimento na fase anterior, transformou-se em uma ação encaminhada 'para dentro' do movimento. Sobrevieram infinitas discussões de caráter político-ideológico que levaram progressivamente a um esvaziamento do Movimento Popular em Saúde, cuja paralisação política foi notável no fim dos anos 80 e início dos 90 e será mais detidamente abordada no capítulo seguinte. 


\section{O Movimento Médico}

No que se refere ao Movimento Médico, outro componente do Movimento Social em Saúde, optamos por estudá-lo por meio da atuação das entidades médicas - as associações de caráter sindical, as que regulam o exercício da profissão médica, as de caráter técnico-científico e as que congregam os profissionais com a finalidade de discutir questões próprias da profissão médica.

Ainda que se trate de um movimento de profissionais, o Movimento Médico é mais que uma associação profissional ou uma modalidade de articulação sindical na defesa de interesses da classe médica. É composto de diversas entidades, caracterizadas por um alto grau de institucionalização - diferentemente do Movimento Popular em Saúde -, e presença nos diversos planos em que se desenvolve a vida profissional do médico. Há certa homogeneidade de classe na composição do mesmo, à diferença, também, do movimento popular.

$\mathrm{Na}$ década de 70 e início da de 80, o Movimento Médico liderou seu questionamento às políticas de saúde e à elaboração da proposta de reformulação do sistema, que culminou na Reforma Sanitária. A partir da primeira metade da década de 80 deslocou-se a discussão política da Reforma Sanitária para o Sistema Unificado Descentralizado de Saúde (Suds), observando-se um abandono dos princípios, questão principal da década anterior, por orientações mais pragmáticas na categoria a respeito dos problemas da implantação da política de saúde.

Para o Movimento Médico, a relação com o Estado não constituiu preocupação central à prática do mesmo, como no caso do Movimento Popular. Pelo contrário, os aspectos críticos considerados em relação ao Suds apontam para a 'prefeiturização' e a 'partidarização' dos recursos, mas não a respeito da inviabilidade do Estado para implementar a Reforma Sanitária, considerando-se o Suds como a única saída para a caótica situação do sistema público de saúde.

Desse modo, as entidades buscaram engajar-se nas questões atinentes à política de saúde e entenderam que o Suds era a estratégia para alcançar o Sistema Único de Saúde (SUS). No entanto, percebe-se uma grande distância entre as proposições gerais da categoria e a transformação de sua prática, dentro de uma orientação na qual interesses de caráter corporativo ficassem em segundo plano. Tal afirmação se fundamenta na não-aceitação, pela categoria, dos princípios embutidos na implementação do Suds em relação ao exercício da profissão médica: emprego único, tempo integral e cumprimento de horários. 
É possível perceber, também, que outra questão merecedora de destaque no âmbito da Reforma Sanitária foi a da isonomia salarial. Apesar de apontada como necessária desde a formulação do Plano das Ações Integradas de Saúde, sem a qual esta ou qualquer outra inicial mudança na assistência ficaria comprometida, a isonomia passou, em nosso ponto de vista, a ter importância superior ao próprio projeto da Reforma Sanitária, para a categoria.

Em relação à organização do trabalho médico, a preocupação da classe tem sido a de estabelecer parâmetros que limitem qualquer interferência sobre determinado trabalho, certamente no sentido de garantir a prática liberal mesmo sob condições de assalariamento. Cabe destacar o papel proeminente que a categoria atribui a si nas políticas de saúde. Ao mesmo tempo que não é aceita a renúncia aos privilégios que comporta o exercício liberal da medicina, obrigase o Estado a cobrir os riscos do mercado. Paralelamente, tenta-se manter uma parte importante do poder médico nas mãos dos próprios médicos, a fim de impedir que o Estado interfira sobre o trabalho dos mesmos.

A diferenciação entre o exercício da prática médica e o Estado, no sentido deste não interferir, mas garantir condições para o exercício da mesma através das políticas de saúde, relaciona-se também à natureza liberal das instituições médicas, que se originaram no começo do século como confrarias de profissionais independentes.

A atuação da categoria é institucionalizada e diferenciada. As questões que se referem à atuação profissional dos médicos são canalizadas por diversas instituições médicas, as quais possuem, por sua vez, orientações político-profissionais diversas. A denominação de Movimento Médico obedece a essa atuação diferenciada do conjunto das entidades ou instituições médicas.

Neste sentido, o sindicato dos médicos teve um papel essencialmente trabalhista, defendendo os interesses econômico-corporativo dos médicos, utilizando, como procedimento principal para o encaminhamento das reivindicações da classe, as greves no setor público da saúde. Enquanto isso, os Conselhos Regionais e Federal de Medicina tiveram um papel sobretudo político, especialmente no que se refere à reformulação do Código de Ética Médica e à atuação dentro da Plenária Nacional de Saúde, para a elaboração do capítulo da saúde na Constituição de 1988.

As greves médicas no setor público da saúde contribuíram para o processo de desmonte na implantação da Reforma Sanitária. Independentemente de as reivindicações serem ou não justas, elas conduziram à maior crise de atendimento dos hospitais e postos de atenção médica. Durante meses as filas, as 
mortes por falta de atendimento, a insensibilidade com o sofrimento humano foram a tônica da atuação da categoria médica. À proporção que aumentavam enormemente o desprestígio e a ineficiência do setor público da saúde - somado à falta de repasse dos recursos do Suds às unidades locais, o que ocasionou falta de instrumental, medicamentos e manutenção das instalações -, cresciam as seguradoras privadas de saúde e sua procura pela população.

Paralelamente, a discussão em torno do processo constituinte foi plenamente assumida pelos Conselhos de Medicina, transformando-se estes em centros de mobilização política em torno da proposta da Reforma Sanitária. Posteriormente, já no processo de implementação da política de saúde, logo após sancionada a Constituição de 1988, foi elaborado pelo Conselho Regional local o anteprojeto para a Constituição do Estado do Rio de Janeiro - onde particularmente analisei a atuação das entidades médicas. Nele se defendiam:

- a criação do Sistema Estadual de Saúde, vinculado ao Sistema Único de Saúde;

- a municipalização dos recursos;

- o financiamento, através do orçamento da União da seguridade social, dos municípios e de outras fontes;

- a participação de entidades representativas de usuários e profissionais de saúde nas decisões sobre o sistema, por meio dos conselhos estaduais e municipais de saúde.

Voltou à tona o importante papel de mobilização política que desempenharam os Conselhos, liderando as lutas com conteúdos mais transformadores no campo da saúde. Não obstante, nossa impressão é de que, da mesma forma que na discussão sobre a Ética Médica, não se conseguiu adesão substantiva da categoria em seu conjunto a esses processos transformadores. Tais questões serão melhor desenvolvidas no quinto capítulo, sobre a trajetória do Movimento Médico.

\section{A Teoria de Ação Coletiva: gênese e trajetória da atuação política dos movimentos sociais}

Neste ponto, a finalidade é introduzir a análise da trajetória do Movimento Social em Saúde à luz das teorias da ação coletiva, testar seu alcance explicativo e nos prover de instrumentos que possibilitem prever acontecimentos futuros. 
Vamos partir da concepção de Olson (1965) sobre a ação coletiva. Enquanto ação orientada por grupos em estado 'latente' ou por grandes grupos, a ação coletiva é resultado de um cálculo racional de custos e benefícios guiado pelos interesses dos indivíduos. Supondo-se que os indivíduos são racionais, a estratégia dominante será aquela que melhor satisfazer as necessidades de cada indivíduo.

$\mathrm{Na}$ base da teoria da ação coletiva está a motivação egoísta dos indivíduos, que implica um comportamento em que a racionalidade reside em deixar que outros ajam. Tal situação configura o assim chamado Dilema do Prisioneiro: o mais racional é não atuar e esperar que outros o façam; os outros também não atuam com base no mesmo princípio, e as conseqüências são que a racionalidade individual leva ao desastre coletivo.

Outra motivação possível para Olson é o altruísmo incondicional, só que se trata de um imperativo categórico e, neste sentido, ele o rejeita como sendo "expressão de desejos", sem base no comportamento dos indivíduos. Ainda que considere a existência de "incentivos seletivos", estes não operam indiscriminadamente, como ocorre no caso dos bens coletivos, sobre o conjunto do grupo, mas seletivamente através dos indivíduos que o compõem. Um indivíduo mobilizado positivamente pode contribuir para a ação coletiva, porém é mais provável que isso aconteça em pequenos grupos do que nos grandes.

Se observarmos o que aconteceu com os movimentos sociais nas duas conjunturas escolhidas, veremos que, no caso do Movimento Popular em Saúde no período que culmina com a Nova República, há um crescimento da ação coletiva, seguida de uma fase de esvaziamento no momento de criação e consolidação da institucionalidade democrática.

O que ocorreu na conjuntura da transição? Por que foi um período extremamente marcado pela ascensão das mobilizações populares? As motivações egoístas não foram o princípio da ação? Os custos da ação coletiva eram menores que os benefícios?

Se entendemos por custos as possíveis retaliações que o poder político autoritário poderia desenvolver como resposta à ação coletiva do Movimento Popular em Saúde, corre-se um alto risco logo de início. Entretanto, ninguém garante que o custo - esforço gasto em mobilização - vai significar a provisão de um bem público. Assim, os custos são palpáveis, enquanto os benefícios são prováveis; no entanto, a ação coletiva aconteceu.

O problema nessa teoria é que a noção de 'coletivo' não é discutida, mas simplesmente vista como a produção de uma 'ação agregada' pelo conjunto de 
indivíduos essencialmente egoístas. Porém, se isso é o coletivo, como poderia haver ação coletiva, já que significa o mesmo que ação cooperativa? Ou seja, por que ou como um coletivo se cria, se todos seguem seus interesses egoístas?

Voltemos a indagar: por que a paralisação da ação coletiva foi o sinal que marcou a atuação do Movimento Popular em Saúde no final da Nova República e durante o período do Governo Collor? Já na formulação da pergunta se observa a dificuldade explicativa da teoria. Se houve um momento anterior de aumento da mobilização da gestão do coletivo, como esta poderia existir se são as motivações egoístas, por excelência, que caracterizam o comportamento humano? Se também não se pode explicá-la pela relação entre custos e benefícios, como explicar então a ação coletiva? Não explicada a ação antecedente, como explicar a inação conseqüente?

Essa última questão remete a outra limitação da teoria - a de não dar conta da 'dinâmica' da ação coletiva. Os momentos de mudança da ação para a inação conseguem ser capturados pela teoria, na medida em que se estabelecem relações lógicas, exclusivamente, e portanto absolutas entre variáveis não-absolutas. Entende-se por variáveis não-absolutas, aqui, as particularidades do próprio movimento na gestão do coletivo, a noção mesma de coletivo e a complexidade da conjuntura política que medeia e atravessa os diversos atores que dela participam.

Neste sentido, nossa opinião é de que o 'coletivo' opera simbolicamente no interior do Movimento Popular em Saúde. Significa que a ação se recompõe (o coletivo), enquanto as expectativas dos membros do movimento conduzem a uma identidade em prol de um objetivo, independentemente da certeza de obter o bem público. Isso não significa que não exista um cálculo por parte dos membros do movimento a respeito de participar ou não da ação coletiva, mas a expectativa leva à configuração de um 'si mesmo' e do 'outro', o que tornará o cálculo favorável à participação ou não. Quando não me percebo como 'formando parte de', também não percebo que os outros possam ser partes integrantes de um 'coletivo' que passe a atuar de maneira conjunta em dada situação. Assim, não percebo a cooperação como comportamento possível. A cooperação, ao mesmo tempo que um comportamento induzido por mim, é também induzido pelos outros em mim.

Para outra vertente de reflexão teórica - Laclau, Touraine, Landi -, esses são processos de constituição de identidades coletivas. Tais construções não são dadas, portanto, estão sujeitas a transformações permanentes que têm a ver 
com o próprio movimento, sua formação, organização, atuação política, composição de seus membros etc. Cabe assinalar também que as conjunturas políticas mais gerais, a existência de crises e o caráter destas marcam os próprios processos de formação, avanço e estagnação dos movimentos populares em saúde.

Observando agora a atuação do Movimento Médico, constatamos que em nenhuma das duas conjunturas existiu uma paralisação da ação coletiva do movimento, pelo contrário, em ambos os momentos sua atuação foi intensa. No entanto, o que mudou foram os eixos sobre os quais a atuação aconteceu. Enquanto de fins da década de 70 até a culminação da Nova República, o Movimento Médico teve uma atuação fundamentalmente política e também reivindicativo-trabalhista - na qual o sistema de saúde, seu caráter de reprodutor das desigualdades, a relação perversa entre setor público/privado, os problemas derivados do assalariamento médico maciço foram as principais questões levantadas -, mudanças significativas registraram-se no fim da década de 80 .

O Movimento Médico desenvolveu uma ação coletiva profundamente corporativa, com penetração importante nas entidades médicas do ideário neoliberal e cuja atuação teve como característica marcante sucessivas e inúmeras greves que afetaram profundamente o setor saúde. O que aqui observamos é praticamente um contra-senso da teoria olsoniana da ação coletiva, já que esta se produz precisamente a partir de 'motivações egoístas', se assim pudéssemos qualificar os interesses corporativos.

A esta altura, cabe fazer algumas referências que melhor caracterizem o Movimento Médico. Em primeiro lugar, é ele profundamente articulado em torno da profissão médica. Trata-se de uma categoria de índole diversa da de outras categorias profissionais ou de trabalhadores. É formada por diversas entidades médicas altamente institucionalizadas, com longa data de atuação, já que surgiram no princípio do século e subsistem até hoje, com uma considerável solidariedade orgânica resultante da existência de um Código de Ética Médica e da própria modalidade de exercício liberal da profissão. Isso torna necessário compreender a ação coletiva do movimento, no sentido antes mencionado da 'gestão do coletivo' na sua especificidade.

O considerável avanço registrado nas correntes teóricas do individualismo metodológico em relação à teoria olsoniana da ação coletiva foi a sensibilidade para capturar a dinâmica desse tipo de ação. Neste sentido, ainda que não haja discussão acerca daquilo que seja o 'coletivo' e das motivações que induzem os 
homens a atuarem coletivamente, o fato de considerar a teoria dos jogos como instrumento metodológico principal para "qualquer análise do processo histórico, centrado na exploração, conflito, alianças e revolução" (Elster, 1989) possibilita maior aproximação explicativa a situações nas quais a ação se produz ante aquelas nas quais esta não acontece. Ou seja, se diante de uma situação X um conjunto de atores tem de decidir uma ação de conjunto $\mathrm{Y}$, sendo o comportamento racional de cada um deles e o do conjunto a melhor garantia para o êxito da ação, é plausível inferir que o comportamento não será definido a priori, mas a interação com os outros permitirá escolhê-lo.

A noção de 'coletivo' é substituída, na teoria dos jogos, pela de 'cooperação'. Neste sentido, a teoria dá conta da dinâmica da ação coletiva do Movimento Popular em Saúde. Restaria saber porque o Movimento Popular em Saúde agiu cooperativamente na Conjuntura 1 e não do mesmo modo na Conjuntura 2. Isso requer análise do contexto do Movimento Popular em Saúde em ambas as conjunturas, combinada à própria caracterização delas.

No que diz respeito ao Movimento Médico, as coisas tendem a se complicar ao trabalhar com o enfoque do individualismo metodológico. Mas Elster (1989) faz uma distinção entre a cooperação como modalidade da teoria dos jogos que se dá na classe operária e diz que o problema da solidariedade da classe capitalista requer outros instrumentos de análise. ${ }^{16} \mathrm{~A}$ tarefa dos dirigentes empresariais será a de convencer os empresários individuais a agir de maneira tal que, embora do ponto de vista de cada um deles sua ação não traga nem ganhos nem benefícios, trará sim benefícios coletivos caso seja adotada por todos. A liderança, portanto, consiste em utilizar a 'zona de indiferença' dos indivíduos.

No caso, essa distinção estabelecida por Elster não se adequaria aos comportamentos observados nesse 'particular' movimento social. As questões relativas à profissão médica provêm de uma identidade forte e de uma ideologia médica que marca os comportamentos individuais e coletivos dos membros da corporação. Esta possui características singulares e diversas formas de expressão social composta por entidades que operam em um amplo espectro de atribuições e que se exprimem tanto no âmbito privado (social) quanto na esfera pública (Estado).

16 A tarefa dos dirigentes empresariais será convencer os empresários individuais a agirem de maneira tal que, embora do ponto de vista de cada um deles sua ação não traga nem ganhos nem benefícios, ela trará benefícios coletivos caso seja adotada por todos. A liderança, portanto, consiste em uilizar a 'zona de indiferença' dos indivíduos. 
Apenas a título de destacar semelhanças e sem entrar numa discussão específica sobre o assunto, acreditamos que a corporação médica se assemelha à corporação militar no papel que esta desempenha. Quando os interesses médicos são afetados ou existe uma ameaça a vida da corporação, ou seja, o espaço privado da corporação é invadido pelo Estado, o Movimento Médico tem reagido de maneira forte e imediata. Isso ocorreu na década de 70 , quando as entidades médicas sofreram intervenção, e a consolidação do sistema de saúde levou a mudanças no processo de trabalho médico, tendo com isso submetido esses assalariados ao mercado e às condições de arrocho salarial de qualquer outro trabalhador.

A corporação passou, então, a fazer parte de outros movimentos de oposição. Sua atuação foi marcada pela ação cooperativa, tendo um papel quase de liderança das outras forças sociais - as primeiras greves que aconteceram no País naquele período foram as dos médicos. Acreditamos que à cooperação universal', da maneira que foi formulada pelo individualismo metodológico, falta precisão para ser aplicada à ação coletiva do Movimento Médico.

Em outras palavras, minha disposição em atuar, embora dada pela disposição dos outros e vice-versa, não é suficiente para explicar a ação coletiva do Movimento Médico, regulada em grande medida pelo fato de pertencer à corporação. Não atuar pode significar não ser reconhecido por mim e pelos outros como 'fazendo parte de' e nisso há punições morais, de auto-estima etc. Assim, a corporação médica, na conformação de sua atuação política, tem um eixo ou uma medula pela qual o termômetro desta é dado pelo grau em que são afetados pelo Estado os parâmetros estabelecidos para a categoria e definidos pela própria corporação.

A conjuntura pós-transição, marcada pelo Governo Collor, mostrou que os médicos voltaram a se predispor a atuar coletivamente, colocando em risco a sobrevivência do setor público da saúde na consecução de melhorias salariais e de autonomia no processo de trabalho médico, sem interferência do Estado. A categoria não se submeteu a outras lógicas que não as da corporação, embora isso significasse o abandono da própria proposta da Reforma Sanitária, que tinha sido o eixo de atuação política do Movimento Médico até o fim da Nova República.

Tratava-se de um subtipo de cooperação que chamaríamos de 'cooperação corporativa', na qual não haveria só um cálculo que me levasse a participar se os outros participassem, mas também um jogo simultâneo em que todos 
participam porque a participação é mediada pela corporação. Na cooperação corporativa todos usariam de um tipo particular de solidariedade restrita à corporação. Neste caso, a cooperação tal como formulada por Elster poderia ser 'qualificada', ao acrescentar o tipo de cooperação à qual estamos nos referindo.

A lógica dual da ação coletiva, teoria concebida e assim denominada por Santos (1989), se sustenta sobre o modelo olsoniano da ação coletiva, mas precisamente por isso, ao mesmo tempo em que resolve uma das questões principais embutidas na teoria clássica da ação coletiva - o início da produção de um bem público -, fica presa a esse modelo explicativo e a suas limitações. A idéia é que a ação coletiva acontece para a provisão de um bem público e o fato de não atuar não significa somente que me privarei de consumir um bem público potencial que aconteceria se todos participassem da ação coletiva, mas que serei obrigado a usufruir de um mal público.

Parte-se da idéia olsoniana de que participar ou não da ação implica um cálculo de custos e benefícios, sendo a premissa básica do comportamento humano a de evitar o sofrimento. Tal premissa não deixa de ser, também, um imperativo categórico, ainda que mais inclusivo que o egoísmo. Se participar da ação coletiva tem custos, isso não significa que não participar não implique custos. Pelo contrário, a idéia é que os custos da não participação, para mim, podem ser maiores que os custos da participação, se pelo fato de não fazê-lo me vejo obrigado necessariamente a consumir um mal público. Ou seja:

$$
\text { Cnp }>\text { Cp }
$$

sendo que Cnp = custo de não-produção ou participação

$$
\text { Cp }=\text { custo de produção }
$$

Essa condição formal ocorre quando a consecução de objetivos privados depende da produção de bens públicos - trata-se, possivelmente, de um tipo de interação social que corresponde ao dilema da vontade geral rousseauniana, onde bp (bem privado) = bp (bem público). Acontece independentemente da existência de 'caronas', ainda que às vezes seja necessário eliminá-los para diminuir o custo da produção de um bem.

A relação estabelecida pela teoria entre o custo de produzir um bem privado e a eliminação dos 'caronas' não acrescenta nada à explicação original, formalizando simplesmente a afirmação de que, sendo mais econômico eliminálos, reduz-se o custo de produzir um bem privado, o que é uma verdade óbvia. 
A teoria não diz nada a respeito do significado de eliminar ou não os 'caronas' dentro das hipóteses por ela estabelecidos:

$\mathrm{C} 2 \mathrm{bp}=\mathrm{C} 1 \mathrm{bp}-\left(\mathrm{C}^{\prime} \mathrm{bp}-\mathrm{Cefr}\right)$, onde C2bp é menor que o original C1bp

Quando C'bp - Cefr (custo de eliminar os 'caronas') $=0$ (se for econômico, fazê-lo)

C2b $<$ C1bp alcançará seu valor máximo

Observando-se os movimentos sociais em saúde à luz dessas idéias, estas poderiam explicar porque o Movimento Popular em Saúde teve um desenvolvimento marcante na Conjuntura 1. Atuar significaria - no 'plano simbólico', ainda que isso não seja dito pela teoria - a obtenção de um bem coletivo, no caso, medidas governamentais para acabar com a epidemia de dengue. Não atuar significaria - no 'plano real' - que ninguém estaria eximido de usufruir de um mal público (a epidemia da dengue). Ou seja, o momento inicial da ação coletiva consegue ser capturado pela teoria, mas por ser estática não consegue explicar porque a ação tem continuidade e, no caso, menos ainda a paralisia da ação coletiva no momento posterior da Conjuntura 2.

A teoria não explicita qual é o custo de não produzir um bem público, já que tanto atuar quanto não atuar vão levar ao mesmo resultado - à obtenção de um mal público. No plano simbólico, perderam-se as expectativas a respeito da ação coletiva e, no plano real, sucessivas políticas governamentais de consumo de males públicos foram impostas. A teoria não inclui a dinâmica da ação nem a temporalidade da mesma, mas o fato de definir o resultado da não-atuação dos agentes - como a obtenção de alguma coisa que não é boa para ninguém e não apenas a perda da obtenção de um bem - possibilita, no caso do Movimento Popular em Saúde, explicar a atuação deste como necessária para evitar ser alvo da epidemia de dengue.

No caso do Movimento Médico, a teoria também não nos permitiria discriminar por que tanto na Conjuntura 1 quanto na 2 há ação coletiva. Ela não consegue dar conta do caráter diverso da ação coletiva dos médicos nesses dois momentos.

Por último, cabe a referência, também, à capacidade explicativa da teoria de Offe (1984) sobre a existência de duas lógicas da ação coletiva. Divergindo de Olson, Offe mostra como não há uma lógica unitária e utilitária da ação coletiva 
que cubra todas as associações e como, além disso, as diferenças de poder conduzem a diferenças no tipo de ação coletiva - trabalha aqui com as classes trabalhadoras e capitalistas. Essas diferenças tendem também a ser obscurecidas pelo paradigma de 'grupo de interesse'. Os interesses da classe trabalhadora e os da classe capitalista estão sujeitos, sob o capitalismo, a graus distintos de distorção. Por isso, um processo 'dialógico' - um entendimento e um acordo compartilhado - de definição de interesses é necessário para aqueles que se encontram em uma posição de poder inferior e que dependem, por isso mesmo, de um conceito comum e coletivo do seu interesse.

Offe acha que há um conflito de classe dentro das formas políticas e também um conflito de classe referido às formas políticas. O primeiro ocorre dentro das formas processuais dadas, enquanto o segundo é latente, escondido por uma pretensão de 'neutralidade'. A teoria de Olson só considera a existência desse primeiro nível do conflito, onde os parâmetros se tornam variáveis e a ação coletiva se preocupa com o que quer dizer 'custos' e ‘benefícios'.

Caberia salientar que esses dois tipos de conflito nas classes dominadas nunca se dão de maneira separada. Quando o conflito começa por demandas pontuais, como no caso do Movimento Popular em Saúde, não se mantém estanque, assumindo rapidamente formas político-organizativas que conduzem à redefinição de interesses e à constituição de uma identidade coletiva.

As organizações empresariais representam uma forma política de racionalidade individualista, chamada pelo autor de lógica 'monológica'. As organizações sindicais operárias constituem um 'caso misto' contendo elementos das duas lógicas, já que nelas há uma contradição sempre presente entre burocracia e democracia interna, agregação de interesses individuais e formação de identidade coletiva. Trata-se de uma condição sempre presente não só nas organizações sindicais, mas também inerente a todo o processo de institucionalização no interior dos movimentos sociais.

A partir daqui o que interessa sublinhar em Offe é o aspecto dinâmico no tratamento da ação coletiva - a interação entre os membros da organização e os contextos políticos mais amplos -, que, ao mesmo tempo em que permite incluir as diferenças no caráter do conflito na definição de interesses e, conseqüentemente, o tipo de ação coletiva, permite também formular um modelo dinâmico baseado em estágios da ação coletiva nas organizações operárias.

Tal construção conduz a uma teoria - que Offe denomina de sociológica, e portanto não-valorativa - do oportunismo. Esta é compreendida pelo autor 
como a maneira de resolver o conflito que se apresenta nos estágios posteriores à formação de qualquer organização social. Enquanto as organizações surgem como resultado da mobilização social, num momento posterior esta é substituída pelo crescimento das burocracias e da legitimação das rotinas burocráticas.

A sobrevivência da organização deixa de ser assegurada pela disposição em atuar de seus membros e passa a ser garantida por mecanismos de negociação política, pautados por procedimentos institucionalizados. Trata-se, para Offe, de uma "escolha oportunista", na medida em que esta cresce burocraticamente sem arriscar sua existência. O 'oportunismo', na acepção que o autor lhe dá, tem o status de uma formulação teórica, neste aspecto, e nenhuma conotação valorativa.

Os estágios mencionados podem ser classificados da seguinte forma:

- Estágio 1 - corresponde ao momento de formação das entidades; o padrão da ação é dialógico.

- Estágio 2 - a organização fortaleceu-se e acumulou poder real derivado de seu reconhecido potencial. Recruta, mobiliza e ativa os membros para atualizar seu poder, mas, ao mesmo tempo, deve precaver-se para que os membros não se disponham a agir prematuramente. Não havendo solução segura e permanente para esse dilema, pode-se retornar ao estágio inicial, sendo isso possível acontecer apenas em caso de alto grau de politização da luta de classes; na ausência de condições favoráveis, poder-se-ia passar ao próximo estágio.

- Estágio 3 - a única transformação que não ameaça nem a sobrevivência da organização nem interfere em suas perspectivas de êxito é a resolução 'oportunista'. As garantias de sobrevivência interna são substituídas pelas externas; a organização passa a se sustentar sobre posições de negociação, enquanto antes tinha exclusivamente a disposição para agir de seus membros. Tais práticas institucionalizam-se por meio de estatutos legais. Porém, a solução do dilema se constitui num dilema em si mesmo.

- Estágio 4 - a organização não é mais capaz de resistir às tentativas de retirada do suporte externo, bem como dos estatutos institucionais e legais que lhe são proporcionados a partir do exterior. Neste sentido, terá de se ver obrigada a manter as garantias, sendo o resultado então a burocratização, com a qual os custos em longo prazo do 'oportunismo' se tornam manifestos. 
- Estágio 5 - nova fase de mobilização e ativação dos membros torna-se necessária para defender os termos do dilema, a sobrevivência e as probabilidades de êxito da organização.

Observando a trajetória do Movimento Popular em Saúde, constatamos que sua formação respondeu a uma lógica dialógica, com resistência muito grande a ingressar no Estágio 2. Ingressar significaria, por um lado, a institucionalização e o reconhecimento, por parte do Estado, dos movimentos como interlocutores no campo da negociação política. Por outro, haveria perda de autonomia das entidades populares em relação ao Estado. O problema com o Movimento Popular em Saúde foi que isso suscitou forte polarização de posições ante uma ideologização da discussão que conduziu também à paralisação na ação e à ameaça de não-sobrevivência ou esvaziamento das entidades do movimento.

Para Offe, a questão do oportunismo pode ser defendida como a única solução racional e realista para aquelas tensões, dilemas e tradições internas manifestas como conseqüência do Estágio 2. Se uma organização proteger tanto sua existência quanto suas realizações potenciais, parece não haver caminho senão o sacrifício parcial de sua autonomia.

Os estágios explicitados no desenvolvimento das organizações das classes dominadas, se aplicados ao Movimento Popular em Saúde, se tornam profundamente contraditórios. Ao mesmo tempo que o 'oportunismo' constitua talvez o caminho mais curto para acabar com eles, em razão das intrínsecas características e da formação e organização desses movimentos, a opção pela não-institucionalização produziu uma paralisia na ação coletiva. Mas, simultaneamente, sua fluidez colaborou para sua própria reestruturação ante situações que o afetavam diretamente, como a crise dos hospitais do setor público e a falta de atendimento médico-hospitalar para essas populações.

No caso do movimento médico, o modelo de ação aplicado para as organizações da classe operária ajusta-se perfeitamente ao sindicato médico. Em relação às outras entidades médicas não se aplica nem a lógica dialógica, nem a monológica, de forma estrita, ainda que se possa encontrar elementos das duas. Nosso ponto de vista, já aqui assinalado, é de que os médicos constituem uma corporação de características singulares e, neste sentido, a 'ideologia médica' da corporação merece ênfase particular. 


\section{Algumas Observações Teórico-Metodológicas}

A discussão primordial a respeito da transição à democracia e o seu processo de construção e/ou consolidação teve como propósito estender a noção de democracia para além da consideração dos procedimentos restritos à implementação da democracia política. A consolidação da democracia é indissoluvelmente ligada à conformação de estruturas democráticas nos diversos níveis da sociedade para os quais o estabelecimento de condições relativas Estado/sociedade afiguram-se fundamentais.

Discutiu-se a questão da cidadania como uma categoria central à democracia, distinguindo o conceito clássico da cidadania do exercício histórico da mesma. Essa distinção e o percurso escolhido para desenvolvê-la levaram à conclusão de que a eqüidade está embutida na cidadania não como 'princípio', mas como resultado das lutas sociais que transformaram a 'idéia de cidadania', configurando nela a obtenção de direitos concretos usufruídos pela população, enquanto a justiça social redunda na regulamentação da eqüidade como valor ético-moral.

Esses direitos de cidadania, consagrados juridicamente, se concretizaram mediante forte intervenção do Estado na economia, restringindo o papel do mercado e introduzindo importantes reformas no capitalismo, com a implantação de políticas sociais e os conseqüentes benefícios sociais para as classes trabalhadoras, via Welfare State. Enfrentar tais questões possibilita, sem que isso constitua um modelo a ser reproduzido, estabelecer bases para a discussão da construção de um regime democrático.

A visão das políticas de saúde, sob a perspectiva das políticas sociais, obrigou a um mergulho no campo teórico-conceitual envolvido nessa área de conhecimento. As dificuldades que acompanharam o processo de implementação da política de saúde exemplificam de maneira bastante aproximada as difíceis relações Estado/sociedade no momento de consolidação do processo democrático, sendo a Reforma Sanitária um caminho de reconstrução da democracia por meio de reformas parciais, ou, dito de outra forma, de consecução da democracia pela via do estabelecimento de 'regimes parciais' democráticos.

A necessidade de criar o processo de implantação da Reforma Sanitária levou à discussão teórica a respeito dos processos de formulação e implementação de políticas sociais. As dificuldades de regimes de democratização parcial prosperarem e se instalarem estão estreitamente vinculadas ao encaminhamento das inovações políticas no campo das políticas sociais. 
Também fizemos referência ao papel dos movimentos sociais em saúde nesses dois momentos, a formulação e a implantação da política de saúde, com ênfase na particular atuação dos movimentos à luz das diversas teorias da ação coletiva. A reflexão crítica relacionada às teorias da ação coletiva possibilitou identificar, a partir das trajetórias dos movimentos sociais em saúde, as adequações, proximidades e distanciamentos entre os diversos enfoques teóricos e também o desenvolvimento da atuação política dos atores nela privilegiados.

Acreditamos ter alcançado um arcabouço teórico que nos aproximou da idéia de pensar as políticas de saúde da perspectiva dos atores em relação ao Estado, nos processos de transição e construção da democracia. A política de saúde foi vista, assim, sob uma perspectiva societária, ainda que, pela própria natureza desta, seja na arena do Estado que ela adquire concretude. A própria complexidade do processo da Reforma Sanitária exigiu o exercício teóricometodológico e obrigou a expandir o ângulo de visão em múltiplas direções. 
Parte II 


\section{Movimento Popular em Saúde}

O fim dos anos 70 e o início dos 80 se constituíram marco para a política brasileira em torno do processo de democratização do País. Amplo espectro de forças sociais - sindicatos, entidades profissionais, associações de bairro, movimentos contra a carestia, minorias e partidos políticos - empreenderam uma luta política que conseguiu aglutinar diversas formas de associação para exigir do regime militar eleições livres e diretas para a Presidência da República.

A luta em prol da democratização consistiu de uma saída política de oposição à ditadura militar ante a proposta das Forças Armadas, anunciada pelo então Presidente da República, Ernesto Geisel, de fazer uma abertura "lenta, gradual e segura". Era um momento em que a sociedade, como um todo, estava mobilizada e direcionada para a consecução de eleições diretas.

Denominaremos 'movimento social' o conjunto das novas formas de associação, independentemente do tipo de reivindicação e de articulação institucional que tenham conseguido alcançar. Essa ampla definição obedece a uma determinada maneira de compreensão do objeto de estudo, assim como também à abertura oferecida pela teoria dos movimentos sociais.

Nos anos da transição à democracia, a efervescência social se expressou na grande quantidade de organismos da sociedade civil que emergiram e se reproduziram nas grandes metrópoles e em seus bairros periféricos, sob a forma de sociedades de fomento, associações profissionais de classe média, postos de atendimento básico de saúde, escolas comunitárias, creches.

No cerne da constituição da vertente popular dos movimentos sociais estavam, por um lado, as reivindicações por demandas de habitação, saúde, educação e saneamento decorrentes das necessidades pelas quais atravessa grande parcela da população. Por outro, proliferaram as associações de classe média, 
registrando-se as primeiras greves de oposição ao regime militar no sindicalismo de classe média e, particularmente, no setor médico.

De fato, o arrocho salarial com o qual se defrontou a sociedade brasileira como um dos resultados da política econômica do regime militar - não afetou somente as classes operárias, mas, ainda, importantes setores assalariados da classe média, os quais também sofreram deterioração das condições de vida. ${ }^{17}$

Designamos Movimento Médico a atuação do conjunto das entidades médicas no período de transição à democracia, em razão, fundamentalmente, do papel político que os médicos - organizados em associações de caráter profissional, científico e sindical - tiveram nesse processo, característica que se diluiu à medida que a transição adquiriu perfil mais nítido. Mantivemos, no fim da década de 80, a denominação 'movimento médico' para nos referirmos à atuação política do conjunto das entidades de representação da classe, e intitulamos de 'corporação médica' a atuação mais especificamente voltada para reivindicações de caráter econômico-corporativos dos médicos.

Analisamos a atuação do Movimento Médico, no período que vai de 1976 a 1990, através das seguintes entidades: Conselho Regional de Medicina do Rio de Janeiro (Cremerj), Sociedade Médica do Estado do Rio de Janeiro (Somerj), Sociedade de Medicina e Cirurgia do Rio de Janeiro (SMCRJ) e Sindicato dos Médicos (SinMed). O material e as entrevistas realizadas com as lideranças das associações médicas localizadas no estado do Rio de Janeiro cobre o período que se estende de 1983 a 1990.

O Cremerj corresponde, na esfera nacional, ao Conselho Federal de Medicina (CFM) e o SinMed à Federação Nacional dos Médicos (FNM), ambas reconhecidas pelo Estado. A primeira regula e supervisiona a prática médica, outorga o registro profissional e atinge, portanto, o conjunto da categoria médica. A segunda representa os interesses profissionais - condições de trabalho e salários - da mesma. Já a Somerj e a SMCRJ são entidades de caráter privado e correspondem, na esfera nacional, à Associação Médica Brasileira (AMB). As

7 Para se analisar os movimentos sociais, não se deve ensejar generalizações apressadas, mas ter em mente a necessidade de um conceito que seja suficientemente abrangente para dar conta da diversidade de movimentos, surgidos em contextos sociopolítico diferentes e/ou marcados por matrizes organizativas distintas. Considerar que os movimentos sociais em sua concretude podem ser definidos pela conjugação das contradições históricas e estruturalmente dadas, pelas influências da conjuntura política e, sobretudo, pela forma como agem e reagem as partes em conflito, ou seja, pela efetividade que assumem as proposições de natureza organizativa/política/ideológica no jogo das relações sociais, cultura e instituições (Doimo \& Bank, 1989). 
duas, como entidades de filiação voluntária, congregam os médicos em defesa de seus interesses profissionais, discutem as políticas de saúde e desenvolvem atividades de caráter técnico-científico.

Ao nos debruçarmos sobre a teoria da ação coletiva enquanto modelo explicativo da atuação política dos movimentos sociais em saúde, enfatizamos as limitações que tais teorias detêm. Sublinhamos a dificuldade, embutida nessas concepções da ação coletiva, de dar conta de processos de formação de identidades sociais e políticas que dizem respeito não só a um cálculo em relação à participação, mas também à própria noção do 'coletivo'. Considerar essa questão do 'coletivo' e dar-lhe maior precisão nos obriga a penetrar nas questões específicas que a trajetória e a atuação dos movimentos sociais colocam.

A problemática que envolve a análise dos movimentos sociais de extração popular e, neste caso, a dos movimentos populares em saúde, relaciona-se basicamente a três eixos de questões decisivas em processos de formação, assim como na atuação dos mesmos: a relação com o Estado, sua institucionalização e a autonomia em relação a outras forças políticas.

No âmago da constituição dos movimentos sociais estão as reivindicações por demandas de habitação, saúde, educação, saneamento etc., decorrentes das necessidades pelas quais grande parcela da população urbana atravessa. Ao considerar que o Movimento Popular em Saúde tem seu eixo de atuação no plano das políticas de saúde - área específica de intervenção do Estado -, constatouse que a concepção do Estado, assim como a relação com este constitui seu 'calcanhar de Aquiles'. O movimento deixa de ter uma existência virtual no momento em que se relaciona com o Estado, já que este passa a ser o alvo da ação coletiva e, neste sentido, elemento polar em sua constituição.

Os processos de construção de identidades políticas no Movimento Popular em Saúde e nos movimentos sociais em geral estão intimamente relacionados ao papel do Estado, na medida em que este ocupa posição de destaque para a consecução de melhores condições de vida, de saúde e de atendimento à saúde. Entretanto, como esse processo é operado simbolicamente - ou seja, mediante as 'representações' que o movimento popular tem sobre si mesmo -, não é necessário que o Estado preencha efetivamente esse lugar. Pelo contrário, sua omissão no preenchimento desse papel opera à maneira de interpelação pela qual o movimento popular se constitui para exigir sua presença na esfera da saúde. Trata-se de uma tensão permanente, de uma dinâmica contraditória e constituinte que caracteriza a relação entre Movimento Popular em Saúde e Estado. 
Cabe ressaltar que a existência do movimento é indissoluvelmente relacionada à mobilização, já que é por meio desta que ele deixa de ser virtual e adquire realidade. Se considerarmos ainda que toda ação coletiva nas classes populares é direcionada para reivindicar a presença do Estado para que este efetue a melhoraria das condições de vida das comunidades, fica evidente o papel constitutivo do Estado na dinâmica dessas relações.

É interessante observar que os movimentos sociais, quando provêm da sociedade civil, nascem desvinculados da ordem política, mas passam a ocupar espaço público ao reivindicarem demandas cuja satisfação requer a intervenção estatal. Desse modo, também se reaviva a discussão do social no âmbito interno do Estado. O movimento social tem, portanto, papel principal no encurtamento da distância entre a esfera privada e a ordem pública. Mas isso só pode acontecer na medida em que a ação política do movimento efetivamente aconteça e a relação com o Estado seja recriada.

A institucionalização dos movimentos populares é um outro eixo problemático no desenvolvimento da atuação política dos mesmos. Trata-se de preocupação legítima nos movimentos populares em saúde, uma vez que essa atuação está marcada pela heterogeneidade de seus membros, pela presença de diversos partidos políticos, diante do esforço por manter a independência dos mesmos, e pela maleabilidade do próprio movimento, o que dificulta o estabelecimento de regras de funcionamento para a sua organização.

A ação coletiva nesses movimentos tem, freqüentemente, um importante componente de decisão política não-direcionada institucionalmente. A ausência de estruturas institucionais mais sólidas que contenham as práticas do Movimento Popular em Saúde é característica compartilhada com os movimentos populares em geral.

De fato, observa-se resistência à institucionalização, associada à autopercepção de perda de autonomia, ao encastelamento das lideranças e à instrumentalização do movimento por políticos locais, os quais se apóiam nas burocracias dos ministérios para a obtenção de favores - para eles é mais fácil negociar com as direções do movimento que em situações de mobilização popular, pois, desse modo podem controlar os termos da negociação. Ainda que essa autopercepção tenha forte viés ideológico, também se sustenta na própria prática do movimento popular, já que mais de uma vez foram trocados 'votos por bicas'.

É importante destacar que tanto neste ponto quanto no que se refere à autonomia dos movimentos, importantes ganhos foram obtidos pelo Mo- 
vimento Popular em Saúde nos momentos em que, pelo próprio crescimento da ação coletiva dos mesmos, houve também uma crescente tendência à institucionalização e a procedimentos de negociação política mais formalizados.

A institucionalização conforma, portanto, outro de seus pontos de estrangulamento ou de tensão. Quando se pensa no grau de articulação dos movimentos populares, geralmente se faz referência à capacidade dos mesmos para agir coletivamente - reivindicações de melhores condições de vida, de saúde, de atendimento etc. - e não à qualidade de ser institucionalizado. Porém, essa modalidade de articulação, sustentada exclusivamente na ação coletiva, dificulta a percepção, por parte do próprio Movimento Popular em Saúde, de um fio condutor que dê continuidade ou historicidade à sua ação política, o que resulta, também, em impedimento no desenvolvimento de avanços continuados e sustentados que os transformem em definitivos protagonistas das políticas de saúde.

Em relação à autonomia do movimento, esta se coloca perante outras forças políticas tais como partidos, técnicos, religiosos e também perante o Estado. Mas tal questão é falsa. Na verdade, a tão propalada autonomia não passa de discurso, pois os movimentos, para terem existência própria, necessitam de articulações políticas. ${ }^{18}$

Como será visto adiante, ao analisar a trajetória do Movimento Popular em Saúde efetivamente constatou-se que a influência da Igreja progressista, assim como a dos partidos de esquerda, foi decisiva em sua formação e desenvolvimento. Neste sentido, quando os movimentos populares carecem de articulação com outras forças políticas, dificilmente conseguem incidir nas decisões políticas mais amplas. Ainda que isso possa significar risco de diluição do movimento dentro de outras forças sociais ou políticas mais estruturadas, cabe ao próprio desenvolver mecanismos que garantam a continuidade.

Desse modo, a autonomia em relação ao Estado é uma questão principal para o movimento. De fato, o que se tem observado freqüentemente é o esvaziamento dessas mobilizações quando cooptadas pelo Estado (Nunes \& Jacobi, 1980). A idéia que predominou no Movimento Popular em Saúde desde sua

18 De fato, observa-se que os articuladores sociais têm desempenhado um papel significativo, o que não tem representado necessariamente perda de autonomia, tão reivindicada pelos movimentos. Mas esse ocultamento das conexões políticas que envolvem posições partidárias ou confessionais não pode ser minimizado no caso do Movimento Popular em Saúde, já que, apesar das resistências dos seus integrantes, salta aos olhos a influência dos setores progressistas da Igreja através das Comunidades Eclesiais de Base, dos médicos sanitaristas e de militantes do Partido dos Trabalhadores, que, embora não formalizem laços orgânicos com a estrutura partidária, explicitam uma cultura política característica do partido (Jacobi, 1989). 
formação foi a de que a política do Estado é cooptá-lo nos canais de participação popular abertos por ele, uma vez que nestes o movimento não tem poder de decisão.

Ao mesmo tempo em que o Estado é constituinte do Movimento Popular em Saúde, sob a perspectiva deste é percebido como desorganizador da sua ação coletiva. Essa questão se situa no âmbito da atuação do movimento face às políticas de saúde e pode ser bem exemplificada pela discussão interna a respeito da participação ou não nas instâncias institucionais criadas pelo Estado no setor saúde, dado que estas poderiam vir a se constituir em uma via de cooptação e de desmobilização.

O que a experiência demonstra é que por vezes isso tem acontecido, mas nem sempre. $\mathrm{O}$ tema da autonomia nos movimentos sociais nos parece estar associado à sua institucionalização, pelo fato de colocá-lo diante da necessidade de estabelecer mecanismos formais de organização e de funcionamento. Estes, por sua vez, servem de controle sobre a própria atuação do movimento nos Conselhos de Saúde sempre que os movimentos conseguem ter uma atuação decisiva nas políticas estatais de saúde, como vem acontecendo com o processo de descentralização e com a formação dos Conselhos de Saúde.

O dilema que a institucionalização coloca é a quota de burocracia que a acompanha e que constitui uma importante ameaça de extinção do movimento - se considerarmos que este não é um sindicato e nem um partido político - e que, desse modo, as mobilizações sociais radicam na capacidade de atuação coletiva mais do que na organicidade político-institucional.

\section{A Formação: fase reivindicatória}

A formação do Movimento Popular em Saúde foi iniciada simultaneamente à discussão no campo da saúde relacionado à medicina comunitária. Esteve intimamente ligada às experiências das comunidades de base da Igreja no Terceiro Mundo, que se expandiram por todo o País durante a década de 70.

Em suas origens, o movimento estava localizado principalmente nos estados do Rio de Janeiro, Minas Gerais e São Paulo. Era composto por médicossanitaristas, estudantes, religiosos, militantes católicos, integrantes de partidos políticos e das populações menos favorecidas agrupadas ao redor das sociedades vicinais e de experiências comunitárias católicas em bairros das periferias urbanas e em favelas. 
As universidades, por intermédio dos departamentos de medicina preventiva, tiveram também importante influência, já que nelas ocorria a contestação ao modelo médico hegemônico caracterizado pelo elitismo, pela sofisticação tecnológica com baixo impacto nos níveis de saúde da população e, sobretudo, pelo caráter privado e mercantilista. A partir daí surgiram propostas de modelos alternativos, sendo a medicina comunitária a mais importante.

Desse modo, dezenas de experiências começaram a ser realizadas no País, ligadas às universidades, à Igreja ou mesmo ao voluntarismo dos agentes da pastoral da saúde, dos militantes dos partidos de esquerda e, ainda, dos profissionais de saúde com prática nas comunidades. Essas experiências introduziram uma nova concepção do exercício da medicina, sustentada na simplificação do ato médico, na valorização do trabalho auxiliar dos leigos e na participação comunitária. A partir disso, começou-se a gestar uma articulação nacional do Movimento Popular em Saúde.

O I Encontro de Experiências de Medicina Comunitária (Enemec) aconteceu em Lins, São Paulo, sob iniciativa do Instituto Paulista de Promoção Humana (IPPH), do Movimento de Amigos de Bairro de Nova Iguaçu (MAB) e de outras experiências de medicina comunitária em diferentes regiões do País. O IPPH de Lins é uma instituição pertencente à diocese local que, à época, desenvolvia um trabalho de formação de agentes de saúde em algumas regiões do estado de São Paulo e do Triângulo Mineiro. O MAB - ligado à diocese de Nova Iguaçu, no Rio de Janeiro, desde 1975 - desenvolvia um trabalho na área de saúde na região da Baixada Fluminense.

Naquele momento, a medicina comunitária colocava-se como alternativa ao sistema de saúde, na medida em que o setor público de saúde se deteriorava como resultado da crescente privatização da assistência médica. O setor se caracterizava pelo repasse de verbas para o setor privado, com a conseqüente deterioração dos hospitais públicos, as filas para atendimento, a ausência de assistência que cobrisse as necessidades mais prementes da população carente e, paripassu, com a tecnificação e medicalização da medicina, inacessível à população.

Intensas discussões e a produção crítica do Movimento Sanitário levaram à cristalização de uma corrente de pensamento, com introdução de políticas alternativas de saúde por meio de experiências comunitárias. Estas tinham como princípio a simplificação dos cuidados de saúde, de maneira que estivessem ao alcance da comunidade através da atenção primária, sem instrumental de alta complexidade e com a participação de agentes de saúde da própria comunidade, além da supervisão e adestramento dos profissionais de saúde nela inseridos. 
O Movimento Popular em Saúde contou, em suas origens, com a participação de líderes religiosos, que se tornaram dirigentes populares e técnicos da saúde. Estes últimos eram em sua maioria médicos, enfermeiras e outros profissionais de nível superior, funcionários de universidades e secretarias estaduais e municipais de saúde atuando localmente organizadas.

Exemplos dessas experiências foram os projetos denominados "Montes Claros", "Lajes", "Niterói”, "Cachoeiras de Macacu” e tantos outros. Tratavase, também, de profissionais ligados, em sua maioria, a uma militância política no Partido Comunista Brasileiro (PCB) e no Partido dos Trabalhadores (PT). Os técnicos, os religiosos e os dirigentes populares compunham um variado mosaico de ângulos políticos, visões de mundo, contradições, mas com alta identidade de princípios e de posições.

Não é fácil estabelecer a influência que cada um desses componentes exerceu sobre o conjunto do movimento, mas é inegável o poder de opinião dos técnicos e religiosos no direcionamento político e na atuação do Movimento Popular em Saúde.

O movimento procurou manter uma atuação independente, ainda que seu início tivesse coincidido com a mobilização no interior da academia e, timidamente, nos aparelhos de Estado, secretarias estaduais e municipais de saúde. Mas, junto a essa postura autônoma, a questão saúde era vista como instrumento de conscientização e politização para o crescimento do Movimento Popular em Saúde, sem que se percebesse que isso, por si só, pudesse vir a se tornar uma área de decisão política sobre a qual o movimento poderia exercer importante influência.

Nesse momento inicial da formação do Movimento Popular em Saúde (Mops), em fins da década de 70, a problemática relacionada à política nacional de saúde não era visualizada como um eixo de atuação do mesmo. Muito pelo contrário, o que predominava era o afastamento das políticas estatais de saúde, entendendo-se que a participação nestas colocaria em perigo a autonomia do movimento. Esse afastamento voluntário levou à postergação, no tempo, da emergência do movimento como ator político na esfera nacional. A postura de 'independência' ou autonomia constituiu-se, ao longo da história do Mops, como uma das questões mais paradoxais observadas nesta pesquisa.

Em 1979, registrou-se a primeira proposta de promover a articulação nacional do Mops reunindo as diversas experiências locais de medicina comunitária que se expandiam por todo o País de maneira espontânea e com o apoio 
também das dioceses. Consta a participação de 332 representantes de 18 estados e de 1 Território. Os delegados eram, em sua maioria, constituídos por técnicos ligados a universidades ou a secretarias estaduais e municipais de saúde.

A característica marcante desse I Enemec foi valorizar as experiências locais que apontassem para uma organização popular independente. As experiências institucionais em andamento - "Lajes", "Montes Claros" etc. - incentivavam a participação da população, mas, quando esta ocorria, não chegava a superar o nível instrumental, dado que essa mesma população era convidada a contribuir com o projeto sem que houvesse uma participação mais decisiva. Isso fazia com que crescesse enormemente a idéia de independência e de afastamento das políticas estatais de saúde por parte do movimento e de suas lideranças. O relatório apresentou a descrição das experiências desenvolvidas e revelava a preocupação dos delegados com a conscientização e politização das camadas populares por meio da saúde.

O processo de organização do Movimento Popular em Saúde, através das práticas de medicina comunitária, foi gradativamente aumentando e já no II Enemec pudemos observar uma mudança na composição dos delegados, na maioria representantes dos movimentos populares articulados organicamente em federações, associações de moradores, comissões de saúde etc. Representantes de algumas regiões do País propuseram, nesse Encontro, transformar o Enemec em encontros nacionais de movimentos populares em saúde. Entretanto, a proposta só conseguiria vingar mais tarde.

A novidade, naquele momento, foi a preocupação dos movimentos populares em discutir e acompanhar as propostas institucionais - como, por exemplo, o caso do Prev-Saúde. A assistência médica foi considerada dever do Estado e o sistema de saúde como devendo ser universal, igualitário - referindo-se a um tratamento igual para os trabalhos rurais - e com participação dos trabalhadores, em conjunto, na elaboração da Política Nacional de Saúde. No aspecto organizativo, a comissão organizadora passou a ser composta por um representante de cada estado do País.

O IV Encontro, realizado em 1983, abandonou a medicina comunitária como principal eixo temático-organizativo do Movimento Popular em Saúde para se constituir, ele próprio, na motivação principal dos encontros, transformados em instância de organização política do movimento em âmbito nacional. A denominação mudou para Encontro do Movimento Popular em Saúde e seu tema geral foi "Saúde, uma Conquista do Povo". 
Podemos observar, tanto em relação aos temas específicos considerados quanto ao tratamento dos mesmos, que a reunião teve caráter marcadamente ideológico. ${ }^{19} \mathrm{O}$ relatório final incluiu uma série de diretrizes para a atuação do Movimento Popular em Saúde, expressos nos seguintes pontos:

- controle dos serviços de saúde pelos trabalhadores;

- melhoria e igualdade dos direitos previdenciários e de serviços de saúde no campo e na cidade;

- ações preventivas para a conquista da saúde, tais como terra para plantar e morar, salário justo, emprego, saneamento.

Assim foi-se configurando a articulação nacional do movimento, bem como a preocupação de se estabelecer contatos mais estreitos com outros movimentos sociais e sindicais. Essa articulação foi definida como tendo base local. Optou-se, também, pela não-institucionalização, entendida como a obtenção de personalidade jurídica. Foi proposta uma coordenação nacional para a organização do movimento, constituída por dois coordenadores por estado, os quais se encontrariam duas vezes por ano e definiriam rumos. Como estrutura de apoio, os encontros teriam uma secretaria-executiva que funcionaria no próprio estado, que também sediaria o encontro nacional seguinte.

Esse quarto encontro foi um ponto de inflexão na trajetória do Movimento Popular em Saúde em que já se pode perceber o ingresso em uma nova fase, de caráter marcadamente político não só em relação aos temas considerados, mas também nas tentativas de se desvencilhar das lideranças religiosas e técnicas, tal como pela procura de uma articulação sustentada nas lideranças de extração popular das federações estaduais e federais das associações de moradores de bairros e favelas.

Os encontros nacionais, a partir de então, passaram a se desdobrar em dois grandes momentos de discussão:

- um no qual se convidam assessores especialistas no tema, com eficiência e compromisso junto ao movimento popular. Sua função, no caso, é de formação e informação das lideranças populares. Neste momento a conjuntura política nacional é analisada e a política e os serviços de saúde se tornam objeto de debate.

19 Temas abordados: Controle dos Serviços de Saúde pelo Povo; Movimento Popular em Saúde e Movimentos Populares no Momento Atual; Avaliação, Diretrizes e Organização do Novo Movimento. 
- outro, para a definição da estratégia política do movimento como um todo em relação às políticas de saúde, quando são lançadas as teses, diretrizes e bandeiras de luta.

O V Encontro do Movimento Popular em Saúde refletiu, então, os avanços em todos esses anos, não só no tocante à organização, mas também à passagem de uma organização centrada na atuação política local/regional que, na realidade, já exercia grande pressão e tinha influência junto aos órgãos municipais e estaduais. A grande mudança observada em torno da temática e das propostas do relatório final do Encontro foi a ênfase na Política Nacional de Saúde como tópico de destaque.

As diretrizes formuladas nesse Encontro foram:

- participação do povo na elaboração, execução e organização de conselhos populares de saúde para a fiscalização dos serviços;

- mudança e controle da Previdência Social pelos trabalhadores;

- fim de convênios com empresas particulares e de medicina de grupo;

- uma Central de Medicamentos controlada pelo povo e com incentivo e financiamento de pesquisas em medicina popular;

- formação de profissionais de saúde voltados para a medicina preventiva e para as práticas de medicina popular;

- igualdade, nos serviços de saúde, para o homem do campo e o da cidade;

- serviços públicos gratuitos em todos os níveis de atendimento ambulatorial e hospitalar e prioridade à medicina preventiva.

O debate de maior peso na futura organização do movimento se deu quando da transformação da mesma em entidade com personalidade jurídica. A discussão foi particularmente difícil pelas implicações que acarretava. O principal argumento em defesa dessa tese repousava na possibilidade de se obter a independência financeira do movimento, que, dessa forma, poderia receber recursos de várias fontes outras que não apenas a de órgãos governamentais, possibilitando assim que se fortalecesse a estrutura centralizada e a tornasse mais ágil.

O status jurídico facilitaria, também, uma direção capaz de decisões mais rápidas e uma equipe de assessoria para fomentar o trabalho de formação das bases do movimento. A essa idéia se contrapunha o argumento de que aí estava 
o caminho para o atrelamento do movimento ao Estado e sua conseqüente burocratização e afastamento das bases.

Ainda que a institucionalização e a obtenção de personalidade jurídica não significassem necessariamente o atrelamento ao Estado, essa visão era predominante no movimento popular e bastante defendida pelos coordenadores. As diferenças em torno dessa questão não foram resolvidas e voltaram à tona nos sucessivos encontros, influindo decisivamente na atuação do Movimento Popular em Saúde.

A composição social dos coordenadores era bastante heterogênea, já que incluía tanto lideranças de origem popular quanto profissionais de classe média e religiosos. As diferenças políticas entre tais lideranças eram consideráveis, iniciando-se pelo divisor de águas entre a esquerda secular e a esquerda católica e, por sua vez, pelas divergências entre os diferentes partidos políticos de esquerda dentro dessas duas vertentes. Naquele momento de transição do movimento, porém, posições ideológicas de autonomia extrema eram defendidas até como uma forma de preservação do movimento popular. Assim, observou-se essa posição em relação aos partidos políticos, refletida na reunião de coordenadores realizada em Brasília, em setembro de $1985 .^{20}$

Até o início da década de 80 a identidade do Movimento Popular em Saúde foi dada principalmente pela mobilização em torno de demandas pontuais em relação às condições de saúde da população e a respeito das quais o Estado se omitia. Nesse momento inicial do Mops, a Igreja terceiro-mundista e a doutrina da Teologia da Libertação tiveram papel decisivo, através das comunidades eclesiais de base.

A primeira metade dos anos 80 caracterizou-se pela organização regular das associações de moradores dos diferentes bairros e favelas das diferentes regiões do País. Essas associações estavam dispostas a discutir problemas comuns, fazer sua leitura política a respeito deles e propor uma atuação visando intervir nas decisões estatais do setor saúde. Se organizaram em torno de fede-

20 "Vimos que o partido político é uma das ferramentas, isto é, uma das formas de organização que temos. E nós, agentes pastorais e/ou educadores, temos um grande desafio: o de construir um novo exercício político de forma séria e comprometida com as bases. Por essa razão é que devemos ter claro a natureza de cada ferramenta de que dispomos, o que cada uma nos oferece, e onde como e quando podemos usá-la. O Mops tem que ser alheio aos partidos por ser um movimento formado por entidades, grupos e pessoas de diferentes religiões e ideologias. Não devemos ser puristas, mas termos claro os pontos que nos unem e encontrarmos uma forma democrática de convivermos com essas várias diferenças" (Relatório final da Reunião de Coordenadores - Brasília, 1985). 
rações de associações vicinais nacionais e estaduais, as quais se reuniam periodicamente, elegiam suas direções, se uniam em seções ou departamentos de saúde, de terras, de moradia, de educação, dentre outras. Adquiriram, ao longo da década, crescente visibilidade e relevância política.

O aparecimento de outras formas de atuação política, que naquele momento da política nacional começavam a adquirir expressão saliente, marcou também a década de 80. Partidos políticos e sindicatos deixavam de ter uma atuação limitada para passarem a definir plataformas de governo, políticas e linhas de ação. Nesse contexto de democratização e de liberalização política, a Igreja e as comunidades eclesiais de base perderam a hegemonia política que caracterizara a década anterior em termos de oposição e de articulação da sociedade civil.

Tais transformações foram plenamente acompanhadas pelo Mops, observando-se naquele período, de um lado, uma evolução das diretrizes que guiaram a sua atuação, deslocadas da problemática local para a nacional. De outro, o abandono da medicina comunitária pela discussão da política nacional de saúde. Neste sentido, as origens do movimento foram marcadas por sua atividade em nível local. O centro da preocupação nos bairros e nas comunidades rurais era o atendimento médico, os remédios caseiros, as parteiras, a formação dos agentes de saúde etc., tudo enfim que fazia parte do cotidiano desses movimentos e que era contemplado pela concepção da 'medicina comunitária'.

Nenhuma das questões referidas aos modelos assistenciais, ao financiamento do setor, ao gerenciamento, ao caráter público ou privado do sistema de saúde desperta, à época, interesse nos integrantes do movimento. Ainda que existisse uma preocupação relacionada à política nacional de saúde quando da divulgação do Prev-Saúde em 1983 - política de saúde anterior ao projeto das Ações Integradas de Saúde (AIS) -, tal discussão adquiriu seu ponto de maior inflexão na VIII Conferência Nacional de Saúde.

Pode-se visualizar, no quadro seguinte, os principais aspectos que caracterizaram o Mops no período analisado: 


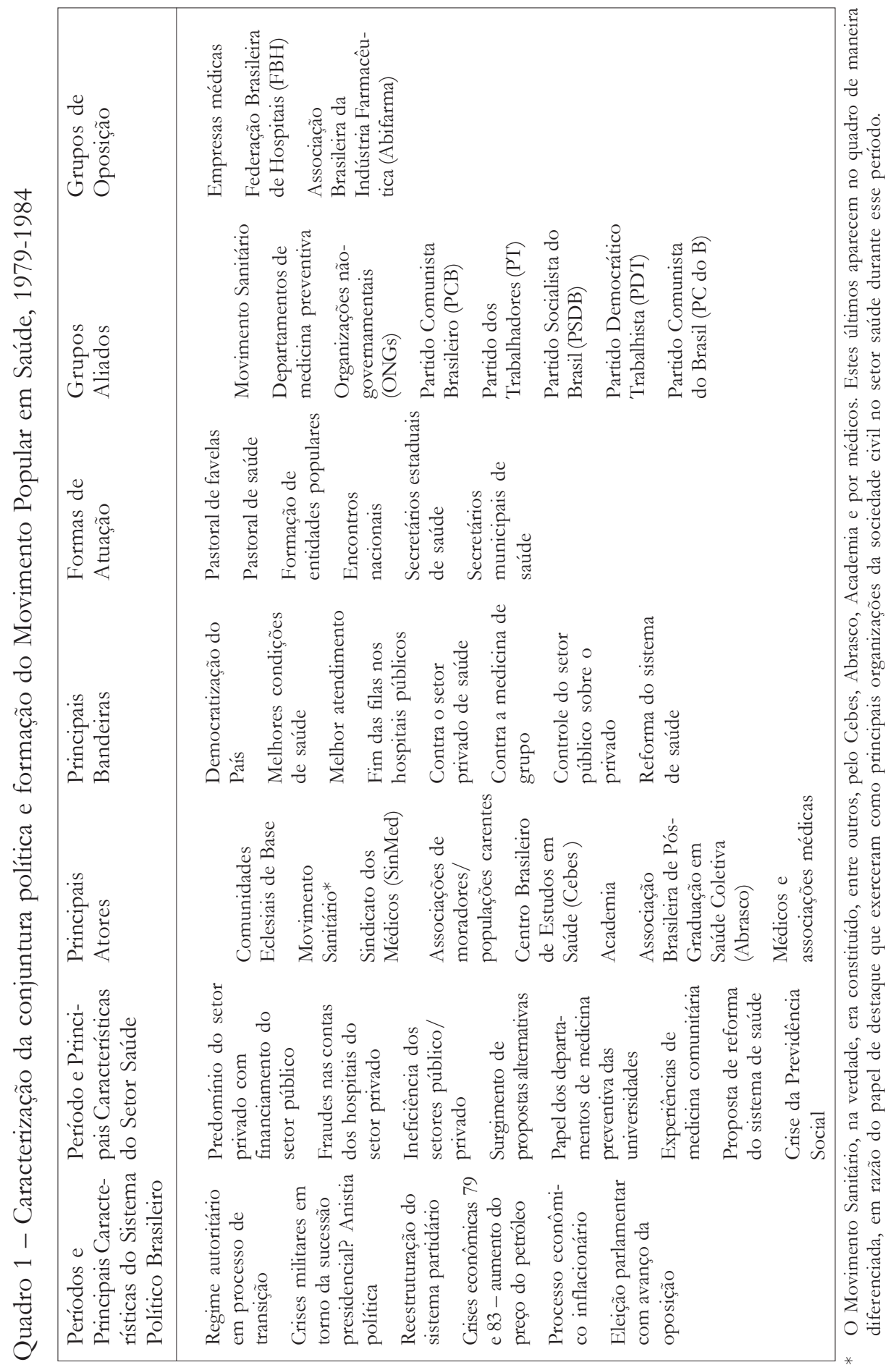




\section{A Ascensão: a politização do movimento}

Em fevereiro de 1986 realizou-se o VI Encontro Nacional do Mops, tendo este sido um dos últimos encontros de caráter nacional, pouco antes da VIII Conferência Nacional de Saúde. Ainda que o tema geral tenha sido "Saúde e Constituinte" e os temas específicos similares aos dos outros encontros, algo de novo e de importante surgiu para o movimento: a inclusão do Mops como delegado na conferência.

A VIII Conferência Nacional de Saúde, convocada pelo Ministério da Saúde através do Decreto Lei no 91466 de 23/7/85, convidou as organizações da sociedade civil a participar através de delegados que as representassem, diferentemente de conferências anteriores. Assim, o evento contou com representantes de várias entidades da sociedade civil - da CGT, da CUT, da Contag - de associações de profissionais de saúde e também do Movimento Popular em Saúde, chegando a somar mil representantes de organismos societários.

Tal fato colocou os participantes do Encontro diante da necessidade de explicitar as teses do movimento, em função dos temas da Conferência: Saúde, Dever do Estado Direito do Cidadão, Reformulação do Sistema Nacional de Saúde e Financiamento do Setor. Após a discussão desenvolvida nesse VI Encontro, foi elaborado e aprovado um amplo documento com duas partes: uma referida à Conferência e outra encaminhada à discussão pela Assembléia Nacional Constituinte.

A preparação desse documento resultou em transformações tanto na concepção do movimento - pelo fato de participar de uma instância de decisão nacional da política de saúde - quanto pelo exercício de explicitação das propostas e estratégias do movimento popular em relação à questão da saúde.

A primeira parte do documento incluiu temas previstos na Conferência enfatizando a saúde de forma ampla, sendo o atendimento médico apenas um aspecto da mesma. Assim, defendiam:

- a estatização dos serviços de saúde e o controle dos mesmos pela população;

- a autonomia dos movimentos populares em relação ao Estado;

- leis que assegurassem a participação dos trabalhadores no planejamento, na execução e no controle dos serviços de saúde;

- a criação de conselhos populares de saúde ligados às prefeituras;

- a unificação e a descentralização das decisões e do planejamento; 
- o aumento das verbas para a saúde e a definição dos recursos, em âmbito nacional, estadual e municipal, através da criação de um Fundo Único de Saúde. Neste ponto foi ainda incluído um item referido na Constituição, recomendando a suspensão do pagamento da dívida externa, o direito de greve, a reforma agrária, a proibição de propaganda de medicamentos, a política de saúde de acordo com interesses populares e a reformulação da Lei $\mathrm{n}^{\circ} 6179 / 74$, que instituía amparo previdenciário para as pessoas com mais de 70 anos.

A segunda parte do documento - que se refere ao direito à saúde e a como ele deveria ser assegurado pela Constituição - propugnava que o fosse por meio do tratamento das aposentadorias, da assistência médica da Previdência Social, da diminuição do poder das empresas multinacionais de tecnologia médica e, sobretudo, da indústria farmacêutica no setor da saúde e da implantação de medicinas alternativas. A última questão incluída no documento foi a divulgação dessas propostas na esfera estadual e nacional. O marco da trajetória do Mops na última metade dos anos 80 foi dado pela VIII Conferência Nacional de Saúde.

Para compreender a particular importância dessa Conferência, em especial, cabe determo-nos na história desse órgão de definição da política de saúde.

As Conferências foram instituídas como instância decisória da política de saúde pela Lei no 378 de 13/1/1937, devendo sua convocação sobrevir com intervalo máximo de dois anos. Mas a I Conferência aconteceu somente em 1942, três anos após o previsto por lei, tendo as seguintes sido convocadas em intervalos irregulares.

Em relação a conteúdos, a III Conferência, convocada pelo Ministro da Saúde Wilson Fadul - ardente defensor das teses de municipalização (Labra, 1988) -, registrou proposições inovadoras que anteciparam a reformulação do sistema de saúde. Mas foi a VIII Conferência que congregou a presença de organismos da sociedade civil e, particularmente, dos movimentos sociais em saúde, pela primeira vez na história das políticas de saúde.

As conclusões espelhavam o amplo consenso em torno da necessidade de introduzir mudanças no setor de forma a torná-lo democrático, acessível, universal e eqüitativo. As propostas convergentes à formulação da Reforma Sanitária brasileira se sustentavam numa conceituação da saúde que, como direito, extravasava os limites da assistência médica, implicando uma série de direitos correlatos - educação, moradia, lazer, participação e liberdade, organização e expressão -, direitos dos cidadãos a serem efetivados pelo Estado. 
A partir da VIII Conferência, o Mops se estabeleceu como força política no cenário da política nacional de saúde, tendo seu projeto inserido na proposta mais ampla de mudança nesse setor no País. Esta foi apresentada por outras forças políticas no nível da academia e de instituições da sociedade civil, como o Centro Brasileiro de Estudos em Saúde (Cebes), a Associação Brasileira de Pós-Graduação em Saúde Coletiva (Abrasco), o movimento sindical e os partidos de esquerda.

Ainda que as discussões evidenciassem diferenças entre os representantes dos diversos setores da sociedade civil, estas não chegaram a prejudicar os resultados da Conferência. Os delegados do Movimento Popular em Saúde apresentaram uma proposta de estatização do setor, sem participação nenhuma do setor privado, a qual não contou com a aprovação da maioria das entidades representadas, dentre elas o Cebes, a Abrasco e as centrais sindicais.

As teses levadas para a VIII Conferência pelo Mops também foram propostas para a Constituinte. ${ }^{21}$ Durante a campanha para a eleição dos candidatos à Constituinte, o movimento popular apresentou-lhes as teses, procurando identificar os que com elas se comprometiam. Uma vez eleita a Assembléia Constituinte, o Mops passou a formar parte da Plenária Nacional de Saúde na Constituinte, levou suas teses à discussão pelas forças políticas aliadas que integravam a Plenária e encaminhou, posteriormente, emenda popular para a área da saúde.

O VII e último encontro nacional do Mops foi em fevereiro de 1987. Ainda que o movimento continuasse existindo na esfera nacional, os encontros seriam posteriormente interrompidos. Desde a VIII Conferência Nacional de Saúde, a trajetória do movimento popular adquiriu outras características, em razão da avançada proposta da Reforma para as questões principais da reformulação do sistema de saúde: a existência de um sistema único e descentralizado de saúde nos estados e municípios.

O movimento passou, então, a ter feição estadual e municipal no processo de implementação da Reforma, tendo os encontros sido substituídos pela Plenária Nacional de Saúde como âmbito de articulação nacional. Assim, as federações estaduais e os organismos municipais de bairros e favelas - dioceses profissionais de saúde das secretarias estaduais e municipais de saúde, militantes, deputados estaduais e vereadores dos partidos progressistas - passaram a ter papel preponderante no encaminhamento da proposta da Reforma Sanitária.

21 Foi, inclusive, elaborado um cartaz amplamente distribuído junto aos movimentos locais e também um documento para a discussão nas bases. 
Esse VII Encontro do Mops na cidade de Cachoeira do Campo em Minas Gerais foi organizado pelos movimentos da região metropolitana e do Vale de Mucuri $^{22}$ que aderiram à articulação nacional no encontro anterior e contou com a participação de 138 delegados de 18 estados. ${ }^{23}$

A articulação nacional, que fora a tônica pela qual se estruturara e crescera $\mathrm{O}$ Movimento Popular em saúde, deslocou-se para as instâncias estadual e municipal devido ao grande impulso e vitalidade que se deu às mesmas como espaço de participação popular. Isso estava relacionado ao próprio processo da Reforma Sanitária, que recomendou como eixo central da reformulação da política de saúde a descentralização, exigindo do Movimento Popular em Saúde uma atuação reforçada nos níveis locais para dinamizar os Conselhos de Saúde, já que neles é que a população passaria a ter assento e papel decisório na implantação da Reforma.

Houve deslocamento também na temática do Mops. Enquanto as origens foram marcadas pela medicina comunitária como modo de dar conta das carências de saúde das populações pobres das grandes cidades e do interior, nesse segundo momento, ligado à realização da VIII Conferência, passou-se a enfatizar a política de saúde.

As experiências estaduais e municipais do Mops variaram de lugar para lugar e dependeram, em boa medida, do desenvolvimento que os movimentos já tinham conseguido antes da realização da VIII Conferência.

A escolha do estado do Rio de Janeiro para avaliar a atuação do Mops no final dos anos 80 e na primeira metade dos anos 90 se fundamentou na feição estadual do movimento e no desenvolvimento que este até então havia adquirido no estado, onde congregava na Baixada Fluminense, desde 1975, o Movimento de Amigos de Bairro de Nova Iguaçu (MAB). Neste estavam agrupadas todas as associações de moradores locais, tendo se tornado federação em 1981 e posteriormente a maior federação de associações de bairro do País - a Federação de Moradores do Estado do Rio de Janeiro (Famerj) -, formada em 1978 (Mainwaring, 1988). Assim, a pesquisa que deu sustento ao livro estudou o Movimento Popular em Saúde neste estado.

22 Herbert de Souza (Betinho), Sonia Fleury e Ivo Poletto foram os assessores do VII Encontro.

23 A dinâmica foi semelhante aos encontros anteriores e os temas tratados foram: Saúde do Trabalhador, Saúde da Mulher, Saneamento Básico, Pastoral da Criança e da Saúde, Hanseníase. Plantas Medicinais, Hortas Comunitárias e Saúde do Consumidor. A Constituinte, ainda tema desse encontro, foi debatida: delineou-se o perfil de seus integrantes - conservadores em sua maioria -, assim como as possibilidades das teses populares serem incluídas no texto constitucional. Foram discutidos também os temas apresentados pelos assessores sobre a conjuntura nacional, o sistema de saúde do País e a reforma agrária. 


\section{O Mops no Estado do Rio de Janeiro}

Nova Iguaçu era a maior cidade-dormitório do estado. Tỉnha, em 1980, segundo dados do último censo, 1.522.400 habitantes. Era exclusivamente de moradia ou de alojamento, isolada do local de trabalho. Por ser cidade-dormitório, sua população tinha características socioeconômicas que a distinguiam da do município do Rio de Janeiro e da do resto do estado. Era, na maioria, uma população constituída de jovens em geral, migrantes do Nordeste, sem qualificação profissional, inserida no mercado informal de trabalho com localização laboral no município do Rio e moradora, de maneira precária, em assentamentos sem infra-estrutura urbana.

Essas características fizeram com que o MAB, ao se tornar federação, agrupasse uma população homogênea que tinha como eixo exclusivo de atenção o local de moradia, sem que se considerassem outras questões tais como trabalho etc. Ficou constatada, assim, uma grande proximidade entre as entidades representativas do movimento popular e as bases comunitárias do mesmo, alicerçadas na solidariedade espontânea entre os moradores e no trabalho desenvolvido pelo próprio MAB.

As associações de moradores que integravam o MAB apresentavam composição bem mais homogênea que a Famerj. Enquanto o MAB agrupava o conjunto das associações de moradores de bairros pobres da população de Nova Iguaçu, na Famerj estavam representadas, também, as associações de moradores de bairros de classes média e alta. No total, a Famerj contava, em 1989, com aproximadamente 1.200 entidades filiadas. ${ }^{24}$ Destas, $82 \%$ pertenciam a associações de moradores de bairros de classe baixa e 18\% a associações de moradores de classes média e alta (ver quadro a seguir).

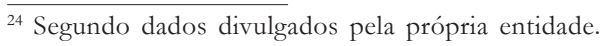


Quadro 2 - Etapa de ascensão do Movimento Popular em Saúde, 1984-1987

\begin{tabular}{|c|c|c|c|c|}
\hline $\begin{array}{l}\text { Entidades do } \\
\text { Movimento } \\
\text { Popular em Saúde }\end{array}$ & $\begin{array}{l}\text { Principais } \\
\text { Bandeiras }\end{array}$ & $\begin{array}{l}\text { Grupos } \\
\text { Aliados }\end{array}$ & $\begin{array}{l}\text { Organizações de } \\
\text { Oposição à } \\
\text { Política de Saúde }\end{array}$ & $\begin{array}{l}\text { Formas de } \\
\text { Atuação }\end{array}$ \\
\hline $\begin{array}{l}\text { Federação } \\
\text { Estadual de } \\
\text { Associações de } \\
\text { Moradores } \\
\text { (Famerj) } \\
\text { Federação de } \\
\text { Moradores de } \\
\text { Nova Iguaçu } \\
\text { (MAB) }\end{array}$ & $\begin{array}{l}\text { Reforma } \\
\text { Sanitária } \\
\text { Sistema Único } \\
\text { de Saúde } \\
\text { Cobertura } \\
\text { universal } \\
\text { Estatização do } \\
\text { sistema de saúde } \\
\text { Saúde - direito } \\
\text { do cidadão } \\
\text { Acabar com o } \\
\text { setor privado }\end{array}$ & $\begin{array}{l}\text { Partidos: PCB, } \\
\text { PT, PDT, } \\
\text { PC do B, PSDB } \\
\text { Movimento } \\
\text { Sanitário } \\
\text { SinMed } \\
\text { Cremerj } \\
\text { Sindicatos não- } \\
\text { médicos }\end{array}$ & $\begin{array}{l}\text { Federação } \\
\text { Brasileira de } \\
\text { Hospitais (FBH) } \\
\text { Associação } \\
\text { Brasileira da } \\
\text { Indústria Farma- } \\
\text { cêutica } \\
\text { (Abifarma) } \\
\text { Seguros privados } \\
\text { de saúde }\end{array}$ & $\begin{array}{l}\text { VIII Conferência } \\
\text { Processo } \\
\text { constituinte } \\
\text { Problemas locais } \\
\text { de saúde } \\
\text { Problemas de } \\
\text { epidemias locais } \\
\text { (dengue) }\end{array}$ \\
\hline
\end{tabular}

A luta pela saúde foi central à Constituição do Movimento de Amigos de Bairro de Nova Iguaçu. Em 1975, através de Caritas Diocesana, foi implantado um programa de saúde composto por quatro médicos. Dois deles, desde 1974, vinham desempenhando um trabalho com a população carente, de atenção à saúde e de formação, através de cursos sobre as condições de vida e necessidade de organização dessas comunidades (Mainwaring, 1988). Origem semelhante teve a Famerj, criada em 1977, sendo os problemas de saúde do estado também centrais na sua formação. "A luta pela saúde ajudou a nascer a Famerj”. 25

A Famerj e o MAB se propunham a coordenar a luta pela saúde no estado do Rio de Janeiro, a executar as decisões das plenárias de saúde, mobilizar as associações nas diversas regiões e representar o movimento junto aos órgãos públicos.

Realizado, em 1980, na Cidade de Deus, uma das maiores favelas da periferia do município do Rio, o Encontro contou com a participação de três mil pessoas representando federações e associações de moradores de bairros e favelas, a Igreja, profissionais de saúde e entidades do movimento operário e sindical do estado.

25 Lucia Souto, presidente da Famerj em 1989. Entrevista realizada durante a pesquisa "Movimentos Sociais, Construção de Hegemonia e Formulação de Políticas: um estudo sobre o Movimento Médico e os movimentos populares em saúde no Estado do Rio de Janeiro”, 1992. 
Também no estado existia uma instância informal de discussão e articulação do Movimento Social em Saúde, como um todo - a Plenária de Saúde ou Fórum Popular -, reunindo os movimentos populares de maneira não-orgânica desde fins da década de 70 .

Pode-se observar, desde o Encontro até 1986, o paulatino crescimento das entidades, a formulação de um estatuto de funcionamento, a definição da estrutura organizacional, eleições periódicas a cada dois anos e a obtenção de personalidade jurídica. Todos esses procedimentos levaram as organizações do Mops à institucionalização, apesar das resistências explícitas das lideranças com orientação 'radical de esquerda', fortemente autonomista e inclinada à não-participação nas políticas de saúde.

Ao longo de 1986/1987 as principais tarefas enfrentadas pelo Mops no estado do Rio foram de articulação Plenária ou Fórum Popular pela Saúde. Designada Plenária Estadual de Saúde após a realização da VIII Conferência, começou a se desenvolver em fins de 1986, enquanto a realização do II Encontro Popular de Saúde do Estado do Rio de Janeiro foi projetada para fins de 1987.

O Fórum Popular pela Saúde foi um permanente espaço de debates, de divulgação de informações e de mobilização em torno de denúncias e de propostas globais para exercer pressão articulada por conquistas de saúde. Nele agrupava-se grande número de entidades da sociedade civil, entre as quais CUT, Instituto Brasileiro de Análises Sociais e Econômicas (Ibase), SinMed, Cremerj, Ordem dos Advogados do Brasil (OAB), Associação Médica do Estado do Rio de Janeiro (Amerj), Famerj, MAB etc. Também os partidos políticos tiveram importante papel, através dos representantes ligados ao setor saúde. Dentre eles se destacaram o PCB, o PT, o PC do B, o PDT e o PSDB. ${ }^{26}$

A criação do Fórum tinha por objetivo a ampla articulação do movimento social pela saúde com as lutas concretas que aconteciam no estado. Sua principal finalidade era, por sua vez, enfrentar a epidemia de dengue, assim como também preparar a participação no processo político que começava a se deslanchar na Assembléia Nacional Constituinte.

Tendo adquirido proporções alarmantes no estado do Rio, onde afetou com maior intensidade a população da região da Baixada Fluminense, a epidemia de dengue evidenciou a ruína do sistema de saúde - "trouxe à tona a

26 Entrevista realizada com Dilceia Nahon, presidente do MAB, 1989. Citada na pesquisa "Movimentos Sociais, Construção de Hegemonia e Formulação de Políticas: um estudo sobre o Movimento Médico e os movimentos populares em saúde no estado do Rio de Janeiro”, 1992. 
falência de tudo, esse problema da falência dos serviços de saúde ficou exposto" ${ }^{27}$-, expressa na desorientação municipal, estadual e federal ante a crise, que exigia resposta pronta e efetiva. O Mops, por sua vez, assistiu perplexo à briga ocorrida entre as diferentes esferas de governo para saber de quem era a responsabilidade no combate ao mosquito.

"Não podíamos esperar resolverem de quem era o mosquito", se explicaram os líderes do Mops com relação à necessidade de reação. Dada a gravidade e a extensão da epidemia e o caráter das ações do Mops, organizaram-se várias manifestações populares com ampla difusão na mídia. Houve, inclusive, um protesto popular bloqueando a rodovia Presidente Dutra, que liga os estados do Rio e de São Paulo; o protesto teve a participação de moradores dos bairros mais atingidos, das entidades agrupadas pela saúde e até de representantes do Ministério da Previdência e da Secretaria Estadual de Saúde.

O bloqueio dessa importante rodovia foi possibilitado pela resposta das organizações instaladas na Baixada Fluminense, como o MAB, a Federação de Favelas do Estado do Rio de Janeiro e também a Famerj. Cada uma dessas organizações congregava, por sua vez, subestruturas que lhes davam condições de acesso e de ação junto à população. ${ }^{28}$

Os resultados da ação coletiva empreendida pelo Mops foram efetivos tanto para sua unificação e subseqüente atuação como em relação às medidas implementadas pelo governo do estado para o combate à dengue, erradicada por meio da intensiva aplicação de produto eficaz na extinção do mosquito e das larvas.

O que acabou por se tornar óbvia foi a relação entre esse momento - o de maior ascensão do Mops no período - e a crise sanitária provocada por essa epidemia. Neste sentido, a atuação do Mops teve caráter eminentemente político e não meramente reivindicativo, evidenciando a ausência inicial de intervenção do estado no combate à epidemia, intervenção mobilizada pela exigência de ação efetiva com a complementação de políticas alternativas de saúde através de agentes comunitários de saúde, vigilância sanitária nos bairros etc.

A própria atuação e pressão do Mops, ao mesmo em tempo que revelou a inoperância prévia do Estado, obrigou o governo estadual a adotar medidas mais permanentes para enfrentar os problemas.

27 Entrevista com Dilceia Nahon, 1989 (Ver nota anterior).

28 Outras mobilizações aconteceram - na Assembléia Legislativa, na Fundação Oswaldo Cruz (Fiocruz) e na Superintendência de Campanhas de Saúde Pública (Sucam) -, tendo assim possibilitado a generalização e a expansão da luta do Mops contra a epidemia de dengue, sendo criado também para isso um comitê popular de combate à doença. 
Vale frisar que, nesse caso, não estamos nos referindo ao estado como totalidade teórica ou sob uma perspectiva conceitual, mas como estado no sentido de ser o complexo de decisões, de planejamento, de instituições e organizações que o tornam ativo.

Ainda que mais adiante retomemos o assunto da relação contraditória do Mops com o Estado, por ora é preciso assinalar as dificuldades governamentais na implementação de políticas de saúde adequadas. Com o crescimento da pobreza também cresceram assustadoramente a carência de infra-estrutura urbana e as doenças como meningite, dengue, Aids, hanseníase, esquistossomose e cólera.

\section{Declínio: acesso às formas orgânicas da política}

Finalizada a VIII Conferência Nacional de Saúde, no ano de 1986, com uma proposta que obteve apoio das entidades representativas da sociedade, o passo posterior se deu com a articulação do movimento no intuito de implantar a Reforma Sanitária. Esse pode ser considerado o momento de maior complexidade na trajetória dos movimentos sociais em saúde.

O encaminhamento, em nível governamental, das resoluções emanadas da VIII Conferência por intermédio dos Ministérios da Previdência e Assistência Social, do Trabalho e da Educação estabeleceu uma instância de discussão denominada Comissão Nacional da Reforma Sanitária, cuja composição previa representantes de entidades da sociedade civil. No entanto, do ponto de vista formal, essa composição não correspondia ao peso real que as associações da sociedade civil deveriam ter, ficando estas em minoria com relação aos organismos estatais e privados da saúde.

A Comissão tinha apenas seis representantes dos organismos populares CGT, CUT, Contag, Conam, FNM - e 16 representantes de organismos governamentais e privados - Ministérios da Previdência, da Saúde, do Trabalho, da Educação, Legislativo, centrais patronais e prestadores privados de serviços de saúde.

Neste sentido, a ação do Estado, através da Comissão, teve conseqüências não só no que se refere à lentidão no andamento do processo de implantação da Reforma Sanitária, mas, ainda mais grave, na atualização da divisão interna do Movimento Sanitário do Mops, entre posições favoráveis a uma política de caráter institucional/estatal versus os que defendiam a necessidade de uma política 
própria e independente do movimento. Conforme visto anteriormente, era preocupação de parte do movimento do Mops a independência diante de políticas governamentais, isto significava a não participação nos Conselhos de Saúde e em outras instâncias, vistas como formas de controle social.

As diferenças internas existentes no Movimento Popular em Saúde se tornaram evidentes com a formação da Comissão: enquanto parte do movimento começou a se referir à Reforma Sanitária como 'uma proposta de cunho estatal' com finalidade surgida pela necessidade de o Estado operar modificações nas políticas de saúde, sem implementação de mudanças substantivas no sistema de saúde, a outra defendia a Reforma mesmo com as dificuldades que a implementação desse processo comportava.

A partir da formação da Comissão Nacional pela Reforma Sanitária o que se deu foi um deslocamento do embate que vinha ocorrendo no âmbito da sociedade - que culminara com uma proposta de amplo alcance e consenso social - para o âmbito interno dos organismos estatais de saúde.

Essa luta passou então a ser travada no terreno dos enfrentamentos políticos das diversas facções da tecnoburocracia do setor, na consecução dos avanços operacionais previstos pela Reforma Sanitária: a unificação do sistema de saúde, a descentralização da administração, a gestão de recursos, a hierarquização dos serviços e a formação dos distritos sanitários como via de acesso ao sistema.

A mudança no terreno da luta política se explica: o Movimento Sanitário, vanguarda do processo de transformação das políticas de saúde, tinha como estratégia penetrar nos aparelhos de Estado com o objetivo de tentar implementar suas táticas para mudar a direção da política e, assim, privilegiar o setor público (Escorel, 1992).

Era uma questão problemática e a respeito da qual não existia consenso entre as forças sociais que compunham o setor saúde. Desse modo, a participação nos organismos estatais acabou sendo uma decisão unilateral do Movimento Sanitário, o que dificultou sua relação com o Mops no transcorrer da década de 80 .

Nas origens do Movimento Popular em Saúde, os intelectuais e profissionais de saúde que organizaram o Movimento Sanitário se assumiam intelectuais orgâanicos do movimento popular. De fato, tiveram importante papel na formação deste. À medida que ocorreu o crescimento do movimento e que se desenvolveu a discussão a respeito da sua autonomia perante o Estado e os profissionais de saúde, intelectuais e técnicos passaram a ter uma dimensão sui generis, diferenciando-se e divergindo política e ideologicamente do Movimento Sanitário. 
A nomeação de quadros do Movimento Sanitário para cargos técnicopolíticos na direção do Inamps e Ministério da Saúde colidiu com a burocracia e com as rotinas estabelecidas nestes órgãos. Os enfrentamentos ocorridos a partir de 1986 no Ministério da Saúde, e mais fortemente ainda na Previdência Social, estavam permeados pelas lógicas de poder presentes nos organismos estatais; portanto, limitados pela própria relação de forças no interior dos aparelhos de Estado.

As tentativas políticas de transformação do sistema de saúde por parte do Movimento Sanitário, com a ocupação dos espaços por esses ministérios, produziram importantes avanços em prol da Reforma Sanitária. Essas tentativas foram, todavia, difíceis de serem mantidas no terreno da luta estatal e/ou burocrática, o que levou, de fato, à relativização dos resultados, aprofundando-se as desavenças entre o Movimento Sanitário e o Mops, ${ }^{29}$ ao mesmo tempo em que neste se produziam divisões internas.

Em fins de 1986, pouco tempo antes da formação da Comissão Nacional da Reforma Sanitária, o Movimento Popular, por intermédio de suas entidades, e o Movimento Sanitário atuavam, ainda, de forma conjunta na instância por vezes denominada Fórum Popular da Saúde, por outras, Plenária Estadual de Saúde, a qual foi também reproduzida pelo Mops em outros estados.

O objetivo dessas plenárias era garantir a participação do Movimento Social em Saúde no processo constituinte e, ainda, dar prosseguimento institucional ao processo da Reforma Sanitária pela via da incorporação das conclusões a que se tinha chegado, na VIII Conferência Nacional de Saúde, na Constituição.

No processo constituinte, a Plenária Estadual de Saúde do Rio de Janeiro trabalhou a favor da Emenda Popular de Saúde apresentada à Assembléia Nacional Constituinte, discutindo-a e recolhendo assinaturas para sua inclusão. A emenda definia a saúde como direito de cidadania e dever do Estado, e propunha - tal como definido na VIII Conferência - a criação de um sistema único de saúde com comando e controle estatal, hierarquizado e descentralizado, nos

29 Posteriormente à VIII Conferência, a Famerj convocou também o Movimento Popular em Saúde do Estado do Rio para uma reunião de avaliação; resultou um documento que se referia a problemas de caráter organizativo - limitantes de uma participação mais efetiva dos representantes do movimento - e a outros, de caráter político, no sentido de se levantar suspeita de que a VIII Conferência tivesse sido uma forma de legitimar as propostas do governo. Apesar disso, foi positiva a avaliação da Conferência tanto em termos de procedimentos - a exemplo da participação do Movimento Popular - como de resultados. Documento da Famerj, abr/1986. Citado na pesquisa "Movimentos Sociais, Construção de Hegemonia e Formulação de Políticas: um estado sobre o Movimento Médico e os Movimentos Populares em Saúde no Estado do Rio de Janeiro”, 1992. 
estados e municípios brasileiros. Este poderia ser complementado pelo setor privado, por contrato de direito público.

O trabalho se constituiu um ato político importantíssimo para o movimento, na medida em que efetivou sua participação orgânica e institucional no processo constituinte, ao mesmo tempo em que fortaleceu o crescimento geral da luta política do setor saúde.

Inicialmente, a Emenda Popular pela Saúde se situava no âmbito estadual, cujo eixo era a estatização do sistema de saúde. Realizou-se, porém, uma Plenária Nacional de Saúde em maio de 1987, em que se propôs trabalhar, em nível nacional, a favor de um sistema único de saúde. A Plenária Estadual decidiu apoiar o documento da Plenária Nacional, abandonando sua proposta inicial. Entretanto, tal posicionamento não foi consensual. Os pontos que marcaram diferenças iriam se tornar um divisor de águas do Movimento Sanitário e do Movimento Popular em Saúde a partir daquele momento.

Cabe neste ponto mencionar a composição política do Mops. Identificamos a presença de duas grandes facções políticas que conviviam no movimento e poderiam ser caracterizadas da seguinte forma:

- uma facção mais crítica e radical na sua visão do Estado, concebendo-o como espaço exclusivo das classes dominantes. Possuía discurso anti-Estado e considerava que se houvesse medidas favoráveis às classes mais pobres, estas teriam por objetivo o controle social. Assumia, portanto, uma postura autonomista, de distanciamento da máquina estatal;

- a outra facção, ainda que apresentasse uma caracterização semelhante em relação ao Estado como domínio da burguesia, não acreditava que ele fosse monolítico, sem fraturas internas, através das quais seria possível pressionar, negociar e construir alianças que possibilitassem as conquistas sociais em saúde.

A associação dessas facções com os partidos não era tão-somente linear. Os partidos de esquerda tinham diferenças internas que não poucas vezes se distribuíam entre as duas facções, como também havia freqüentes mudanças dentro das próprias facções e, também dentro das próprias facções do Mops.

Enquanto, no primeiro caso, se tratava de uma composição partidária das alas mais radicais do PT, do PDT e do PC do B, a segunda facção se identificava mais com o Movimento Sanitário, composto por uma ampla gama de posições políticas hegemonizadas pelo PCB. De fato, o Movimento dos Amigos de 
Bairro (MAB) teve uma política mais próxima dessa segunda facção, embora também reivindicasse independência e autonomia em relação ao Estado.

Parece pertinente mostrar de que maneira essas questões se apresentavam na dinâmica da atuação política do MAB na Baixada Fluminense. Os projetos que chegaram a ter um encaminhamento ${ }^{30}$ resultaram de "uma sólida aliança nas estruturas institucionais oficias", de acordo com depoimento de liderança do MAB. ${ }^{31} \mathrm{~A}$ mencionada aliança articulou o Mops às instituições estatais de saúde - Inamps, AIS, Cims - e também à academia - Ensp, IMS etc. -, em uma conjuntura nacional de democratização em todos os níveis. Isso permitiu a existência, na estrutura do Estado, de profissionais e de políticos dotados de compromisso ético-político com suas funções de governo e de solidariedade social.

O Programa Especial de Saúde na Baixada (Pesb) fez parte de uma iniciativa que contou com forte investimento da sociedade civil e mostrou sua marca não-estatal, embora necessitasse da colaboração vinda da parceria existente entre o MAB e a Secretaria Estadual de Saúde.

Esse projeto, em especial, foi elaborado e discutido por representantes da comunidade-MAB, do Conselho Comunitário de Saúde e da Famerj com a Secretaria Estadual de Saúde e o Inamps. Teve como proposta a implantação de minipostos, de unidades mistas englobando urgências, de ambulatório e de três hospitais gerais para a Baixada Fluminense. Implantadas mesmo foram apenas as 12 unidades mistas previstas pelo programa, que tiveram sua construção viabilizada pelo Inamps, fornecedor também de parte do equipamento necessário ao seu funcionamento e da verba necessária à manutenção do projeto. ${ }^{32}$

A participação da comunidade na gerência das unidades estava prevista para ser efetivada através de um representante no conselho diretor das mesmas e de uma reunião semanal entre os representantes das associações de moradores e a coordenação do Programa. Em relação aos profissionais de saúde, valorizou-se o salário do pessoal contratado por se entender que era um programa diferenciado e com uma nova proposta de assistência em saúde. Isso incentivou os concursados a assumirem seus cargos.

30 O SOS Baixada, por exemplo, primeiro a se transformar mais tarde no Programa Especial de Saúde da Baixada (Pesb).

31 Entrevista realizada com liderança do MAB. Citada na pesquisa "Movimentos Sociais, Construção de Hegemonia e Formulação de Políticas: um estudo sobre o Movimento Médico e os movimentos populares em saúde no Estado do Rio de Janeiro”, 1992.

$32 \mathrm{O}$ ambulatório funcionava com duas equipes de dois clínicos, um ginecologista, dois pediatras, um dentista e um nutricionista. Incluía, além de agentes administrativos, visitadores sanitários, assistente social e auxiliares de serviços gerais. O setor de urgência tinha seis equipes, das quais a de enfermagem - juntamente com auxiliares, radiologia e laboratório - assistiam também ao setor ambulatório. 


\section{O Pesb visava:}

- garantir atendimento digno, humano e personalizado, por meio de efetivo controle social que assegurasse a cada cidadão e às comunidades o direito de exigir que os profissionais de saúde cumprissem as obrigações contratuais;

- assegurar atenção contínua e integral aos pacientes dos postos comunitários de saúde e a suas famílias, o que implicaria o acompanhamento da evolução dos pacientes atendidos.

- realizar a detecção precoce de subgrupos de risco, assim como atividades de educação para saúde.

- estabelecer mecanismos de referência para exames, consultas, atendimento de urgência e internações em outros serviços de saúde do município, assim como contra-referência para o posto comunitário de origem do paciente.

- priorizar ações voltadas para a redução da morbi-mortalidade, por meio da prevenção, acompanhamento e controle de doenças tais como hipertensão, diabetes, infecções respiratórias, diarréias, imunização, crescimento e desenvolvimento, pré-natal, prevenção de câncer na mulher e aleitamento materno.

O programa não foi gerenciado pelo poder público, mas por uma instituição pertencente à Igreja católica com profundas raízes na pastoral popular, a Caritas, convidada a se inserir no processo a partir dos fortes laços que mantinha com o MAB e com o Conselho Comunitário de Saúde, e também porque apta a gerenciar com eficácia o programa, dada a sua trajetória na Baixada desde 1966. Além disso, porque se trata de instituição sem fins lucrativos. Depois de três anos ficaram comprovadas a eficiência e a qualidade da assistência à população, possibilitada pela intervenção da Caritas e pela participação do MAB.

Os postos, no entanto, começaram a atravessar dificuldades a partir de 1990, devido a atrasos no repasse das verbas, que, além disso, não eram reajustadas de acordo com a inflação. Ademais, os funcionários foram estadualizados nesse ano e o Pesb passou a ser de responsabilidade do estado do Rio, o que acarretou a supressão do caráter de projeto independente.

Quanto aos profissionais de saúde, sofreram perda salarial de $800 \%$ ao fim de três anos. Em 1987, ano de iniciação do projeto, os salários dos médicos equivaliam a US\$ 800 e em 1990 chegaram a valer US\$100. Os recursos repassados ao Projeto pelo estado eram insuficientes para a manutenção das instalações dos postos de saúde e para reposição do material e instrumental necessário ao atendimento. A deterioração salarial, as precárias condições de trabalho e a 
falta de segurança no desenvolvimento do mesmo levaram os profissionais a se recusarem a trabalhar. Por tudo isso, tornou-se inviável o funcionamento.

A questão só pode ser compreendida sob a perspectiva da política nacional de financiamento da área social e, em especial, da saúde, a qual ocupa um lugar subalterno nas prioridades governamentais. Se ainda acrescentarmos à escassez dos recursos as modalidades do repasse dos mesmos, desde a federação até os estados e municípios, tem-se que o que ocorreu com o financiamento do setor saúde é quase incompreensível e nada transparente.

Constatamos, ao observar os valores repassados pela União ao setor público - estadual e municipal - e ao setor privado contratado da área de saúde, que houve um aumento a partir do início dos anos 90, ainda que este tenha sido insuficiente. Enquanto em 1989 o orçamento para o setor correspondeu a 1,85\% do PIB, em 1990 passou a 2,36\% e em 1991 a 2,66\%. ${ }^{33}$

A distribuição, porém, dependeu de uma tabela de procedimentos estabelecidos pelo Ministério da Saúde e Inamps, de caráter nacional e referente a valores diferenciados per capita por grupo de estados, cuja aplicação levou os estados que produziam serviços de maior complexidade, quantidade e qualidade a não conseguirem cobrir os custos dos serviços prestados com os recursos a eles atribuídos (Carvalho et al., 1993). Essa distribuição também não obedeceu aos preceitos estabelecidos na Constituição - os mecanismos não eram transparentes, os valores eram retidos sem explicação, o cálculo do orçamento não correspondia à previsão realizada e assim por diante.

Retomando as divergências internas do Movimento Popular em Saúde, questões mais polêmicas e conflitivas referiam-se à proposta de estatização do setor saúde em contrapartida à proposta de um sistema único de saúde com a presença do setor privado, desde que não subvencionado pelo Estado. A partir de 1987 a trajetória do Mops apresentou-se assinalada por momentos de divisão do movimento - com paralisação na atuação do mesmo - e momentos de unificação e atuação relevante na política de saúde.

Esses percalços do movimento também estavam relacionados à sua institucionalização. Considerando que o Mops foi um dos protagonistas da VIII Conferência Nacional de Saúde, exercendo destacado papel na definição da política de saúde, viu-se, de um lado, diante da necessidade de adquirir formas organizativas mais institucionalizadas que possibilitassem participação na implementação das políticas. De outro lado, viu-se diante da urgência em definir

${ }_{33}^{3}$ Ministério da Saúde, Brasília, 1992. 
de que maneira participaria das instâncias institucionais criadas pelo Estado para o assentamento da comunidade no novo sistema de saúde.

Esses momentos diversos na atuação e organização do movimento podem ser assim visualizados:

Quadro 3 - Os impasses na atuação e organização interna do Mops

\begin{tabular}{|c|c|c|c|c|}
\hline $\begin{array}{l}\text { Divisão do } \\
\text { Movimento } \\
\text { (nov. 1987) }\end{array}$ & $\begin{array}{l}\text { Tentativa de } \\
\text { Unificação } \\
\text { (jul. 1988) }\end{array}$ & $\begin{array}{l}\text { Nova Divisão } \\
\text { (ago. 1988) }\end{array}$ & $\begin{array}{l}\text { Unificação do } \\
\text { Movimento Social } \\
\text { de Saúde (dez. 1988) }\end{array}$ & $\begin{array}{l}\text { Nova } \\
\text { Unificação } \\
\text { (fev. 1989) }\end{array}$ \\
\hline $\begin{array}{l}\text { Estatização total } \\
\text { versus alguma } \\
\text { participação } \\
\text { setorial/privada } \\
\text { Discussão } \\
\text { política interna e } \\
\text { paralisia da ação } \\
\text { coletiva }\end{array}$ & $\begin{array}{l}\text { Em torno da } \\
\text { crise do sistema } \\
\text { de saúde do RJ } \\
\text { Ação coletiva do } \\
\text { movimento }\end{array}$ & $\begin{array}{l}\text { Participação ou } \\
\text { não das instânci- } \\
\text { as institucionais } \\
\text { de saúde criadas } \\
\text { pelo Estado } \\
\text { Discussão } \\
\text { política interna e } \\
\text { paralisia da ação } \\
\text { coletiva }\end{array}$ & $\begin{array}{l}\text { Articulação do } \\
\text { conjunto do } \\
\text { Movimento Social } \\
\text { Convocatória } \\
\text { Cremerj para } \\
\text { Constituição } \\
\text { estadual }\end{array}$ & $\begin{array}{l}\text { Crise da saúde } \\
\text { no estado e Lei } \\
\text { Orgânica de } \\
\text { Saúde }\end{array}$ \\
\hline
\end{tabular}

As diferenças não superadas configuraram uma primeira divisão do Movimento Popular em Saúde, o que rompeu uma unificação mantida desde 1986, mais especificamente desde a VIII Conferência Nacional de Saúde. O rompimento concretizou-se no trabalho em prol da Emenda Popular pela Saúde. Ou seja, a facção do Mops defensora da estatização total e imediata considerou que o texto único da Plenária Nacional de Saúde não postulava uma estatização efetiva, de modo que não assumiu esse compromisso em âmbito nacional.

No ano de 1986 houve eleições para a renovação das diretorias - em maio, na Famerj, e em dezembro no MAB. As eleitas na Famerj se identificavam com a proposta de estatização total do setor saúde, ao passo que as do MAB não tinham postura tão radical. A partir do segundo semestre de 1987, a Famerj deixou de trabalhar a favor da Emenda Popular pela Saúde e se voltou para a organização do II Encontro Popular de Saúde do Estado do Rio de Janeiro, ${ }^{34}$ visando reivindicar a autonomia do movimento ante o Estado.

34 Realizado nos dias 28 e 29 de novembro de 1987, esse II Encontro contou com a participação de cerca de 250 pessoas, entre representantes de 57 entidades de caráter geral, sindicatos, organizações não-governamentais e outras, 24 associações de bairro, 23 associações de favelas, de funcionários de órgãos públicos e de profissionais de saúde. O temário incluiu: Reforma Sanitária, Saúde do Trabalhador, Saúde da Mulher, Saúde Mental. Foram discutidos também o papel dos Conselhos de Saúde e, ainda, Conselhos Comunitários de Saúde, Grupos Executivos de Saúde ou outras tantas denominações dadas às instâncias previstas pelo SUS para a participação da sociedade nos aparelhos de Estado do setor saúde. 
De maneira geral, pode-se afirmar que nesse encontro houve uma radicalização por parte do Mops, no que se relaciona às reuniões da Plenária. Isso pode ser explicado, em parte, pela identificação da diretoria da Famerj com a facção mais radical do movimento popular, e de outra parte pelas dificuldades de implantação da Reforma Sanitária, além da frustração das expectativas da população com o governo da Nova República.

A radicalização do movimento e a divisão interna produziram um esvaziamento das propostas e da atuação do Mops, o que ficou evidente no evento, mas que já podia ser observado meses atrás nas reuniões das Plenárias ou fórum. O II Encontro teve escassa mobilização popular. Quanto às conclusões dele extraídas, tiveram caráter marcadamente autonomista e anti-Estado.

Em meados de 1988 o Mops, no Rio de Janeiro, buscou a reunificação, fomentada basicamente por dois fatores: o primeiro relacionou-se com as conseqüências do II Encontro, onde o próprio Mops, em face de seu esvaziamento, percebeu a necessidade de retomar o processo de luta unificadamente.

A questão fundamental, porém, foi a crise do sistema de saúde do Rio de Janeiro, já com nítidos sinais de desgaste devido à crise financeira e política da prefeitura da cidade, responsável pelas principais unidades hospitalares de emergência. O eixo de luta do movimento foi, de fato, a reivindicação de soluções para essa crise. De certa forma, verificou-se uma 'mudança de rota' na estratégia da Plenária, na medida em que se voltou para lutas mais pontuais, principalmente em relação às unidades de atendimento.

A reunificação, no entanto, se rompeu novamente em fins de 1988. Convocada uma Plenária Estadual de Saúde, abandonou-se a denominação Fórum e passou-se a utilizar a denominação única de Plenária, mas as divergências, agora, diziam respeito à participação dos movimentos populares nos aparelhos de Estado. A facção radical defendeu a criação de um Conselho Popular de Saúde ao invés de um Conselho Estadual de Saúde, este aprovado na VIII Conferência e inserido na proposta da Reforma Sanitária. A facção favorável à criação do Conselho Estadual de Saúde entendia este como um instrumento de controle popular da política de saúde.

Já para a facção que defendeu a criação do Conselho Popular de Saúde, o Conselho Estadual de Saúde significava a institucionalização e a burocratização do movimento popular, ou seja, mais um canal de participação aberto pelo Estado como os Grupos Executivos Locais, Conselhos Governo Comunidade etc. visando à cooptação do movimento. Portanto, conclui-se que deveria ter sido 
construída uma instância genuinamente popular, sem a participação do Estado: um Conselho Popular de Saúde em lugar de um Conselho Estadual de Saúde.

As diferenças internas e a maneira como estas se processaram internamente no movimento autorizam a incorporar algumas reflexões teóricas mais substantivas em relação às modalidades de atuação desses atores políticos. Os momentos de maior unidade do Mops coincidiram com as crises no setor da saúde e se refletiram no crescimento da ação política, o que, por sua vez, produziu uma unificação ainda maior, dando novo ímpeto ao processo de construção de identidades políticas ao setor.

Assim, as diferenças entre o Movimento Sanitário, o Movimento Médico e o Movimento Popular em Saúde perdiam sentido perante a dimensão societal que adquiriram as crises de saúde no País. Contrariamente, o desmembramento esteve profundamente ligado a períodos de inatividade política do Mops, em que a 'ação para fora', que caracterizara o movimento, se transformou em 'ação para dentro'.

Queremos dizer com isso que na existência de períodos em que a atividade estava direcionada à discussão política interna do Mops, as duas facções do Movimento tentaram impor sua própria linha político-ideológica, acabando por produzir uma discussão de cunho ideológico que, em verdade, operou como 'camisa-de-força', paralisando assim o movimento. As questões centrais dessa discussão passaram pela autonomia, por uma política anti-Estado e pela estatização dos serviços de saúde.

A posição política do Mops era anti-Estado mas, curiosamente, defendia a estatização absoluta dos serviços de saúde. Um dos temas mais debatidos nas reuniões do Fórum Popular pela Saúde e no II Encontro, de 1987, foi a atuação do movimento nas instâncias institucionais criadas pelo governo para dar andamento à política de saúde.

Além das divergências ideológicas quanto à participação ou não do movimento nos Conselhos, houve também heterogeneidade na composição dos mesmos em termos da representação popular e maior ou menor abertura à participação da comunidade. Ou seja, na prática, havia Conselhos em alguns municípios do estado do Rio que tinham apenas papel burocrático, sem efetiva representação popular, enquanto outros favoreciam e/ou conquistavam vitórias para a população.

Essa questão também não era desvinculada do peso político e da organização do Movimento Popular em Saúde nas diferentes regiões do estado, mas 
não era percebida com clareza pelos quadros do movimento, embora a existência de um tal movimento forte e articulado tivesse incidência na definição política e na atuação dos Conselhos.

Outra polêmica intimamente conexa a essa relacionava-se à criação das instâncias de participação e à sua forma institucional. Havia no interior do Mops quem entendesse que por terem sido criadas de 'cima para baixo' essas instâncias careciam de participação popular. No entanto, no caso do Conselho Comunitário de Saúde de Nova Iguaçu, este consignou importantes vitórias, na medida em que cresceu e se fortaleceu com as lutas populares pela saúde desde a sua formação, anterior às diretrizes constitucionais. A institucionalização do Conselho não significou a perda do espaço político conquistado nem a ausência da participação popular.

A institucionalização do movimento foi por parte deste associada à ala mais radical, à burocratização interna e à perda de autonomia em relação aos aparelhos estatais do setor. De fato, o início de um processo de discussão e negociação com secretarias estaduais e municipais de saúde conduziria, necessariamente, a uma reorganização do movimento sobre outras bases. A articulação sustentada exclusivamente na mobilização popular, na qual a identidade política é resultante do enfrentamento com o Estado, se torna insuficiente nesta etapa do processo de implementação da Reforma do Sistema de Saúde.

Com relação à proposta de criação do Conselho Estadual de Saúde, ainda que esta instância não existisse até o segundo semestre de 1993, já tinha sido aprovada em outubro de 1989 pela Constituição estadual. O atraso na sua implantação deveu-se à ausência de decisão política do governo e da Secretaria Estadual de Saúde, sendo efetivada após julho de 1993, quando o Conselho Nacional de Saúde aprovou resolução dispondo sobre a obrigatoriedade de formar Conselhos em todos os estados do País, tarefa delegada aos governos estaduais.

Neste ponto, necessário se faz salientar que as diferenças do próprio movimento popular também contribuíram para que o governo do estado adiasse a decisão. O posicionamento novamente não foi consensual: enquanto uma das facções demonstrou ser favorável, por se tratar de uma instância que favoreceria o controle popular da política de saúde, a outra entendeu que o Conselho Estadual de Saúde geraria um 'impasse de decisão', o que justificava, portanto, a contraproposta de criação de um Conselho Popular de Saúde totalmente autônomo.

Por fim, aprovado pela Constituição do estado, o Conselho Estadual de Saúde não teria o poder desejado por aqueles que o defenderam, tendo em 
vista que o texto final promulgado não era a íntegra do Anteprojeto da Subcomissão da Ordem Social, como esperado, tendo sofrido uma série de cortes. Incluiu-se, dentre estes, a redução do poder do Conselho na política de saúde do estado, embora sua composição fosse paritária entre o Estado e a sociedade civil organizada e detivesse também poder deliberativo.

Ainda que não existisse uma estratégia única do Mops em relação a essas instâncias institucionais, observa-se certa amplitude e maleabilidade desses movimentos, evidenciada em sua atuação conjunta quando os problemas a enfrentar afetavam vitalmente as já precárias condições de vida das populações. Saliente-se que essa discussão se reproduziu naqueles estados do País que já tinham um movimento forte e atuante.

Cabe frisar que o movimento sempre ficou dividido em torno de questões centrais de sua atuação, o que, no entanto, não o impediu de atuar coletivamente. Essa ação coletiva ficou interditada sob as condições de agudização da luta ideológica interna, ou seja, no momento em que esta adquiriu uma dimensão exacerbada perdeu-se de vista o objetivo principal: a ação coletiva como forma de viabilizar reivindicações populares.

Cada vez que o movimento procurou uma homogeneização ideológica, esta funcionou como 'camisa-de-força', o que impediu a atuação do Mops. O espaço conquistado na Plenária Estadual de Saúde foi ocupado pelo Conselho Regional de Medicina (Cremerj), única entidade médica que durante esse período manteve a luta política na categoria médica.

Em fins de 1988, o Cremerj assumiu o papel de entidade articuladora do movimento social pela saúde no Rio de Janeiro, tanto na convocação da Plenária Estadual de Saúde quanto na forma de reunificação do Movimento Social em Saúde como um todo.

O papel político do Cremerj será analisado no início do próximo capítulo, mas assinalamos desde já que à medida que o movimento popular se dilacerava em torno de sua institucionalização, uma outra entidade do movimento social em saúde que tinha legitimidade e competência técnica específica no campo da saúde tornou-se liderança do Movimento Social em suas diversas vertentes.

A Plenária Estadual de Saúde realizou-se na Assembléia Legislativa do Rio de Janeiro em dezembro de 1988 e teve a participação de 200 pessoas. Nela se discutiu a formulação da nova Constituição estadual mediante a participação da sociedade civil organizada, segundo os princípios básicos da VIII Conferência Nacional de Saúde. A idéia era desenvolver em nível estadual o processo de 
formulação da Constituição federal, ou seja, objetivava-se que a Plenária Estadual de Saúde tivesse como modelo a Plenária Nacional de Saúde.

O Cremerj convocou novamente a Plenária Estadual de Saúde em janeiro de 1989, tendo esta sido constituída por três sessões. ${ }^{35}$ Quando da organização desse ciclo de reuniões, o Mops discutiu sua participação, havendo manifestações favoráveis e contrárias. Por fim, decidiu-se pela participação por considerar que a Plenária era um espaço representativo, com capacidade de articulação e mobilização onde se deveria estar presente. O ciclo de debates objetivou preparar um anteprojeto para a Constituição estadual. Porém, a crise do sistema de saúde do Rio de Janeiro fez com que essa questão passasse a ser, de fato, a finalidade principal da Plenária, agregando-se ao objetivo de influenciar a Constituição estadual.

A crise atingira um ponto de calamidade pública após três meses de greve dos médicos e servidores públicos municipais, com a ameaça de fechamento total de várias unidades de atendimento, especialmente as emergências dos três maiores hospitais do município: Salgado Filho, Souza Aguiar e Miguel Couto. Além disso, havia a ameaça da proximidade do carnaval, quando o número de atendimentos de emergência aumentava substancialmente.

Após o ciclo de debates da Plenária estadual, as lideranças do Movimento Popular em Saúde retomaram o processo de unificação que vinham construindo. Ainda que a elaboração da Constituição estadual permanecesse como prioridade na agenda da Plenária, a situação do setor saúde era tão grave no estado que se transformou no eixo principal das discussões.

Evidenciam esse fato a aprovação de um anteprojeto único para a Constituição em apenas dois meses de sessões, assim como a presença maciça de pessoas e entidades nas reuniões. O movimento, de maneira unificada, encaminhou esforços para o enfrentamento da situação da saúde do município e para a aprovação do projeto.

Cabe ressaltar que a crise no setor possibilitou novamente a postergação das diferenças internas no encaminhamento conjunto dos movimentos sociais em saúde e na retomada da relação entre o Movimento Popular e o Movimento Médico. O descaso do governo do Rio de Janeiro diante da 'nova crise de saúde’ trouxe à tona a contradição entre o Mops e o estado. A omissão deste

35 As reuniões abrangeram três temas: Constituição Federal - texto saúde aprovado e suas implicações; Diagnóstico de saúde e assistência médica no estado do Rio de Janeiro; Avaliação e propostas dos movimentos populares e sindicais. 
último deixou as populações carentes praticamente sem atendimento, o que levou o movimento a se articular novamente e reivindicar o direito de a população ser atendida.

Era uma dinâmica contraditória a que caracterizava a relação dos movimentos com o estado, na medida em que a omissão deste interpelava esses movimentos ao mesmo tempo em que a ação coletiva era o instrumento através do qual o movimento exercia pressão sobre ele para intervir.

Dessa forma, o movimento voltou a estar presente na cena política, exigindo a intervenção do estado através de medidas regulatórias que aliviassem a situação calamitosa dos hospitais do município e da Previdência Social.

Em 13 de fevereiro de 1989, a Plenária Estadual de Saúde entregou o seu anteprojeto de Constituição estadual para a área da saúde. Nele constava um Conselho Estadual de Saúde paritário - entre a sociedade e o estado - e deliberativo a respeito da política estadual de saúde. A reunificação do movimento possibilitou que dentre as várias entidades que o assinaram figurasse também um Conselho Popular de Saúde, instância interna do Mops sem nenhum status jurídico e que havia se manifestado contrário à criação do Conselho Estadual de Saúde, tal como já mencionado.

Em junho de 1989 a Famerj realizou o seu V Congresso, quando foi eleita uma nova diretoria, mais heterogênea que a anterior e com posições políticas mais próximas do movimento sanitário. Assim, a entidade tentou retomar a luta pela saúde no estado, junto ao MAB e às entidades médicas, de maneira unificada. Em outubro de 1989 realizou-se um seminário para discutir as Leis Orgânicas Municipais, organizado conjuntamente pela Famerj, Cremerj, MAB e outras entidades.

O seminário foi uma proposta da Plenária Nacional de Saúde, que se rearticulou em 1989 para discutir, influenciar e garantir na Lei Orgânica da Saúde - que regulamenta os princípios constitucionais - as propostas do Movimento Social em Saúde. Nele foi distribuída uma proposta de Lei Orgânica Municipal, a qual continha as idéias do movimento sanitário para ser discutida junto aos movimentos sociais pela saúde nos diversos municípios.

É interessante mencionar a adesão e o encaminhamento dessa proposta pelo Mops, que se colocou favorável à criação dos Conselhos Municipais de Saúde de forma bastante semelhante ao Conselho Estadual de Saúde desde o início do debate acerca das Leis Orgânicas Municipais.

Dessa forma, verifica-se que inicialmente o Mops foi contra a criação do Conselho Estadual de Saúde - durante o decorrer do processo constituinte -, 
mas que num momento seguinte, já aprovada a Constituição Estadual, se posicionou favorável à proposta dos Conselhos Municipais de Saúde desde o começo dos debates. Essa mudança se explica pela perda de hegemonia da facção radical do movimento, o que se refletiu na composição das lideranças das novas diretorias da Famerj e do MAB, respectivamente.

O que transparece da experiência do Mops, apesar das enormes dificuldades que se depreendem da sua trajetória, é a capacidade de agir de maneira fluida na cena política com um considerável componente de democracia interna. Tal condição foi facilitadora para que a facção mais radical não chegasse a se cristalizar na condução do movimento, pois existiu uma alternância nas direções políticas e nas práticas do Mops.

Pode-se observar, ao longo desses anos, um paulatino desgaste dos serviços públicos de saúde, mais notável em alguns estados - caso do Rio de Janeiro -, com o conseqüente descrédito da população diante da falta de eficiência, de instrumental hospitalar, da desativação de leitos, das filas para atendimento e de outras mazelas que assolaram o setor. Essa situação que o setor público atravessou poderia ser chamada de 'contra-reforma'. Caracterizou-se por uma coordenação de esforços dos setores que se sentiram afetados pela proposta da Reforma Sanitária.

Denominamos contra-reforma porque existiu a intenção explícita de boicote ao SUS e ao processo de descentralização:

- Primeiramente, o próprio governo federal fez freqüentes pronunciamentos, desde seu estabelecimento em 1990, sobre a ineficiência dos hospitais públicos, ao mesmo tempo em que repassava as unidades para estados e municípios sem o correspondente repasse de recursos. A falência do setor público da saúde, produzida pelo governo federal, levou ao crescimento, nesse período, dos seguros privados, em detrimento da Reforma Sanitária.

- Em segundo lugar, o setor privado de atendimento hospitalar foi favorecido com a afluência de usuários de classe média, que começaram a recorrer ao setor privado diante do descaso em que se encontrava o setor público.

- Em terceiro lugar, predominaram os interesses políticos clientelistas na área, através do favorecimento pessoal, nomeando pessoas sem idoneidade profissional para a direção de hospitais públicos e de outros órgãos de saúde.

- Por último, o boicote surdo da burocracia estatal contra as mudanças nas rotinas institucionais resultantes do processo de implementação da Reforma 
levou a uma perda de autoridade e de poder decisório por parte da burocracia e dos políticos clientelistas incrustados nas instituições estatais do setor. Assim, foram enormemente dificultados os repasses financeiros, o processo de descentralização e a participação da comunidade na gestão do sistema.

As crises no sistema de saúde no estado do Rio de Janeiro não só refletiram o que acontecia no restante do País, mas também os percalços no processo de implantação da Reforma Sanitária, cujos problemas, de maneira geral, eram os mesmos em todos os estados, apesar das peculiaridades. Foi alarmante o desgaste da rede pública, devido à dificuldade no repasse dos recursos da esfera federal para a esfera local, a qual, por sua vez, os transferia às unidades hospitalares.

A implementação de uma progressiva unificação e descentralização do sistema de saúde teve também seu funcionamento obstaculizado em razão dos conflitos interburocráticos em torno do controle político, administrativo e financeiro entre o Inamps e as Secretarias Estaduais e Municipais de Saúde.

Um nítido exemplo de tais procedimentos pode ser percebido na divergência entre o Hospital da Lagoa ${ }^{36}$ e o Escritório Regional do Inamps. Houve, nesse caso, um conflito de poderes entre a direção do Inamps, que queria nomear o diretor do Hospital, e os novos procedimentos democráticos implantados com a eleição do diretor daquele hospital pelo próprios trabalhadores e pacientes. Tal procedimento foi sustentado como resultado das propostas de transformação do sistema de saúde. Neste sentido, o movimento batizado de SOS Lagoa teve grande repercussão e acabou por ser o eixo de luta do movimento social em saúde em fins de 1989.

Deflagrado com a exoneração do diretor do hospital pelo Escritório Regional do Inamps, O SOS Lagoa tomou grande proporção. Foi articulado por profissionais de saúde, pela população das comunidades locais, associações e federações de moradores - como a Famerj, o Conselho Popular de Saúde, o $\mathrm{MAB}$-, por partidos políticos, sindicatos, deputados, vereadores, artistas e outros, solidários na luta pela manutenção do diretor eleito.

36 O Hospital da Lagoa é um dos maiores hospitais gerais do estado do Rio de Janeiro, tem excelente localização - zona sul do município - e atende à população da região, especialmente das favelas Dona Marta, Rocinha e Vidigal. Em março de 1988, em um processo peculiar, o Dr. Waldinez Lima de Oliveira foi eleito diretor pelos funcionários, com a participação daquelas comunidades. $\mathrm{O}$ Hospital passou então a enfrentar um grande impasse em razão das divergências entre sua diretoria e a do Escritório Regional do Inamps. O alvo desse conflito foi o tipo de administração implementada, que se pautou pela descentralização dos serviços - inaugurou um posto de saúde na favela Dona Marta -, pelo maior rigor nos critérios de compra de material hospitalar, pelo aumento do número de atendimentos etc. Na época foi considerada uma administração de qualidade diferenciada. 
Havia identificação, por parte da população, entre essa luta e a luta pela democracia, bem como era defendida a manutenção do tipo de administração implementada pela direção eleita, alvo então dos conflitos com o Escritório Regional. Essa voltou-se prioritariamente para as comunidades mais necessitadas da área, particularmente as residentes nas favelas do Vidigal, Rocinha e Dona Marta, tendo assumido uma nova postura diante delas bem como tendo elevado de fato o número de atendimentos.

Desse modo, foram criadas as bases pelas quais a comunidade local, o Mops e os profissionais de saúde não poderiam aceitar passivamente o desmantelamento pretendido pelo Escritório Regional. Maior significado nisso tudo foi a unificação não apenas do Mops, mas do movimento social em saúde em seu conjunto, numa luta de caráter local, porém com forte conteúdo político, qual seja, a luta pela democratização da saúde e em defesa de um atendimento voltado para a população mais carente.

Vale assinalar que no que se refere às reivindicações do movimento o conteúdo político das mesmas se traduziu na luta pela efetiva implementação do SUS. Os novos procedimentos democráticos: a eleição direta das autoridades, a participação da comunidade usuária mobilizada nas portas e no interior dos hospitais e o papel pró-ativo dos profissionais de saúde do Hospital nas decisões político-técnico e administrativa, apoiados pelas entidades médicas. O sindicato dos médicos e o Cremerj não foram aprovados pelo Escritório Regional do Inamps, que acabou por exonerar o diretor do hospital. Embora o Escritório Regional do Inamps tenha imposto sua política e o SOS Lagoa não tenha conseguido reverter essa exoneração, a atuação e a mobilização do movimento possibilitaram uma nova reunificação.

Algumas considerações teóricas merecem ser feitas, com o intuito de se compreender quais efeitos e que alcances teve a ação coletiva na trajetória do Mops. A atuação coletiva, inclusive do movimento social em saúde, constituída pela mobilização e ativação dos seus membros, foi alavanca para unificação e deu novo ímpeto ao processo de construção de identidades coletivas no setor. As diferenças no interior do Movimento Sanitário, do Movimento Médico e do Mops, assim como as diferenças entre eles perderam visibilidade, se esvaeceram perante a dimensão que para o movimento adquiriram, como um todo, as crises da saúde no estado do Rio de Janeiro.

O Mops se viu refletido num espelho que não lhe devolveu uma imagem fragmentada, na medida em que conseguiu alcançar presença marcante e reper- 
cussão na esfera pública numa conjuntura política específica, a crise na democratização na gestão do Hospital da Lagoa.

Não se pretende afirmar, a partir dessas reflexões, que momentos de unificação e de estruturação venham a significar transformações ou avanços permanentes na construção da identidade política do movimento. Muito pelo contrário, a trajetória histórica do Mops mostrou que em diversos momentos e segundo a conjuntura política, o que viabilizou ou não a efetividade na implementação de suas propostas foi o próprio encaminhamento político dado pelo movimento a sua atuação. Podemos afirmar que os processos de construção de identidades políticas se desenvolveram na própria prática social e na relação com diversas forças políticas (Landi, 1981).

Em se tratando de construções históricas, estas estão sujeitas tanto a mutações e a transformações da sociedade como da própria esfera da cultura e da política, assim como a ação dos movimentos populares também se sujeita a variações e aos impactos e respostas da esfera pública. A continuidade desses movimentos no tempo não é dada nem pela existência de uma estrutura formal e/ou hierárquica nem pela institucionalização, mas pelos momentos de atuação política nos quais a associação entre os membros é marcada pela gestão do coletivo, que consegue penetrar na esfera pública. Como Touraine afirma, há potencialidade nesses movimentos para se estabelecer e incidir na política. ${ }^{37}$

Estamos nos referindo, também, às condições constitutivas do Mops, nas quais a situação de carência e necessidade a que foram atiradas as populações paupérrimas teve papel de destaque. Precisamente por isso o aspecto reivindicatório foi detonador da mobilização popular para a obtenção de bens como saúde. Mas isso é apenas um momento em sua trajetória, no qual o próprio movimento não fez ainda uma leitura mais abrangente no sentido de uma visão política da sua práxis que justifique a sua existência.

Um outro patamar foi alcançado quando o Mops conseguiu identificar como alvo de sua competência não apenas a falta de assistência médico-hospi-

\footnotetext{
37 “os três elementos constitutivos de um movimento social - a definição do próprio setor social, de seu adversário e do campo de disputa de seu conflito - encontram-se simultaneamente separados uns dos outros, desintegrados e invertidos, o que leva a uma ação mais expressiva do que instrumental, segundo o vocabulário clássico da sociologia (...) a defesa de interesses específicos, a luta contra os empregadores ou mesmo contra a política urbana é que impedem o espírito comunitário de fechar-se sobre si mesmo e permitem-lhe contribuir para a formação de movimentos sociais. Porém, os movimentos comunitários que se formam nas cidades e ainda, é necessário sublinhar, a sua fragilidade e sua fragmentação permanecem antes de tudo no domínio dos movimentos históricos. Isto quer dizer que o seu interlocutor é mais o Estado do que uma categoria social, Estado que é adversário e protetor ao mesmo tempo" (Touraine, 1989:54).
} 
talar, de vacinas, a existência de epidemias não controladas pelas autoridades, mas, principalmente, a política de saúde. Ou seja, acreditamos ter havido um substantivo avanço na conformação da identidade política desses movimentos a partir do momento em que as mazelas da saúde foram vistas como o resultado das políticas para o setor e também quando o Mops se enfrentou com a política vigente e colocou alternativas próprias a sua formulação, já que a ação coletiva não remetia exclusivamente a demandas pontuais, mas à política de saúde como geradora das desigualdades na distribuição da saúde.

No entanto, ao observarmos a trajetória histórica do movimento, foi possível constatar uma fraca articulação social, com ausência de expressão política própria. O fato de esses movimentos serem formados por moradores das periferias pobres das grandes cidades situou as diferenças - a origem dos moradores, a inserção no mercado de trabalho - à frente das semelhanças.

Por um lado, foi exatamente isso que lhes instituiu a força e a riqueza dos movimentos, gerando pluralidade, solidariedade e democracia interna. Por outro, deu-lhes também a debilidade, a incapacidade de se estruturar mais solidamente e, conseqüentemente, de ter uma influência mais decisiva e permanente nos processos de definição de políticas.

Neste sentido, o Mops encontrava-se em estágio intermediário, tendo em vista que sua atuação não se restringia apenas às demandas específicas de saúde. Entretanto, ainda não expressava uma categoria social com articulação e expressão política autônomas.

A seguir, ilustramos a caracterização e as principais questões que ocuparam o Mops no período considerado. 
Quadro 4 - Atuação, composição e declínio do Movimento Popular em Saúde, 1987-1992

\begin{tabular}{|c|c|c|c|c|c|}
\hline $\begin{array}{l}\text { Principais } \\
\text { Atores }\end{array}$ & $\begin{array}{l}\text { Composição } \\
\text { Mops }\end{array}$ & $\begin{array}{l}\text { Principais } \\
\text { Bandeiras }\end{array}$ & $\begin{array}{l}\text { Formas de } \\
\text { Atuação }\end{array}$ & $\begin{array}{l}\text { Grupos } \\
\text { Aliados }\end{array}$ & $\begin{array}{l}\text { Grupos de } \\
\text { Oposição }\end{array}$ \\
\hline $\begin{array}{l}\text { Conselhos de } \\
\text { Saúde } \\
\text { Associações de } \\
\text { moradores } \\
\text { locais } \\
\text { Associações } \\
\text { médicas } \\
\text { Movimento } \\
\text { Sanitário } \\
\text { Cebes }\end{array}$ & $\begin{array}{l}\text { Federação de } \\
\text { Associação de } \\
\text { Moradores } \\
\text { Associações de } \\
\text { moradores } \\
\text { Militantes de } \\
\text { partidos e de } \\
\text { sindicatos } \\
\text { Profissionais de } \\
\text { saúde }\end{array}$ & $\begin{array}{l}\text { Descentralização } \\
\text { Universalização } \\
\text { Controle da } \\
\text { população dos } \\
\text { serviços de } \\
\text { saúde } \\
\text { Fim das greves } \\
\text { médicas } \\
\text { Formação dos } \\
\text { Conselhos } \\
\text { IX Congresso } \\
\text { Nacional de } \\
\text { Saúde }\end{array}$ & $\begin{array}{l}\text { Plenárias } \\
\text { Nacionais de } \\
\text { Saúde } \\
\text { Plenárias } \\
\text { Estaduais de } \\
\text { Saúde Local } \\
\text { - problemas } \\
\text { epidemiológicos } \\
\text { Constituição } \\
\text { Estadual } \\
\text { Partidos } \\
\text { políticos nos } \\
\text { Conselhos de } \\
\text { Saúde }\end{array}$ & $\begin{array}{l}\text { Cremerj } \\
\text { Profissio- } \\
\text { nais não- } \\
\text { médicos } \\
\text { Partidos } \\
\text { políticos } \\
\text { Sindicatos }\end{array}$ & $\begin{array}{l}\text { Federação } \\
\text { Brasileira de } \\
\text { Hospitais } \\
\text { (FBH) } \\
\text { Associação } \\
\text { Brasileira da } \\
\text { Indústria } \\
\text { Farmacêutica } \\
\text { (Abifarma) }\end{array}$ \\
\hline
\end{tabular}

O Mops teve, desde o período de seu surgimento e no contexto da Reforma Sanitária brasileira, uma atuação intensa e complexa que dificultou a tarefa de avaliar resultados. Mas a incidência do movimento na definição da política de saúde esteve estreitamente relacionada aos seguintes pontos:

- capacidade de viabilizar demandas através da ação coletiva;

- desenvolvimento de articulações políticas com outras forças que integravam o movimento social, partidos políticos, sindicatos etc.;

- capacidade de reação e articulação diante das crises do setor saúde, que evidenciavam a omissão do Estado ante os graves problemas epidemiológicos e de funcionamento dos serviços de saúde.

Sua atuação foi irregular, alternando momentos de importante presença no cenário das políticas de saúde e outros mais voltados à discussão interna do movimento, que dificultavam a atuação do Mops e o distanciavam dos centros de decisão na implementação da Reforma Sanitária. 
As origens do movimento foram marcadas pelo propósito de conseguir uma articulação nacional. Entretanto, o surgimento, a evolução, os momentos de crescimento, assim como os períodos de desmobilização - forma como se estruturou e como levou adiante as propostas políticas -, especialmente a partir da VIII Conferência Nacional de Saúde e após a aprovação da Reforma Sanitária na Constituição, incentivaram a atuação do movimento nos níveis estadual e municipal, adquirindo este uma feição de cunho estadual. Neste sentido, optamos, no estágio de implementação do SUS, por estudar o Mops no estado do Rio de Janeiro.

A questão da saúde sempre esteve presente nos movimentos populares, seja entendida como assistência médica ou como condições de vida, saneamento básico incluindo água tratada, esgoto, etc. Seu aparecimento como elemento central de uma forma de organização popular tem início somente a partir de fins da década de 70 .

O surgimento do Mops coincidiu com dois grandes fatos. Primeiro, a revitalização do movimento popular como um todo, que se deu em meados dos anos 70 sob os primeiros sinais de desgaste da ditadura militar. Essa revitalização trouxe à cena política brasileira movimentos diversos com um eixo comum: a postergação econômica, social e política de crescentes contingentes sociais.

Outro fator que colaborou para a mobilização popular foi a crise do sistema de saúde, tendo como conseqüência as intermináveis filas para atendimento da população pelo setor público, assim como o surgimento de uma proposta de política de saúde alternativa expressa em experiências como Montes Claros, Lajes, Niterói e outras. Procurava-se, via secretarias de saúde estaduais e municipais de oposição ao regime militar, fazer com que o Estado passasse a investir em cuidados de saúde das populações carentes.

Nas universidades teve início a crítica ao modelo médico hegemônico, sobretudo por seu caráter privado e mercantilista. Dessas contestações foram propostos modelos alternativos, sendo a medicina comunitária a de maior relevância, quando dezenas de experiências desse tipo começaram a se estender por todo o País. Apesar de seu início coincidir com a movimentação no interior da academia e ainda, timidamente, nos aparelhos de Estado, o Mops procurou seguir uma rota independente.

Essa postura pela organização popular independente, como instrumento de conscientização e politização, explica o afastamento entre o movimento e as 
políticas de saúde implementadas pelo Estado em torno da formação dos Conselhos de Saúde. O que foi refletido pela trajetória e experiência do Mops foi uma atuação não-homogênea neste sentido.

Desse modo, o MAB seguiu uma linha política tipicamente aliancista em relação às instituições estatais de saúde, ainda que mantivesse um discurso de independência e autonomia em relação ao Estado. De fato, sua ação pesou amplamente na implementação das políticas de saúde na Baixada Fluminense. O programa inicialmente chamado SOS Baixada, depois denominado Projeto Especial de Saúde na Baixada (Pesb), foi resultado da mobilização popular e do peso da mesma no processo de implantação da Reforma Sanitária. Porém, esses projetos tiveram vida curta. Paulatinamente deixou-se de repassar as verbas necessárias ao seu funcionamento e finalmente, no ano de 1990, o Pesb foi extinto e diluído no aparato da Secretaria Estadual de Saúde.

Tais fatos tiveram correspondência com o retrocesso político que gerou a modalidade de atuação governamental sustentada no arbítrio do Executivo, sem discussão com a sociedade ou com suas entidades representativas. De fato, a reedição do tradicional autoritarismo que permeou a política brasileira se expressou nos procedimentos de governo utilizados, os quais ignoraram a existência do Parlamento e se valeram de decretos do Poder Executivo. Essa situação reforçou ainda mais as dificuldades existentes nas instituições democráticas, além da impossibilidade de gerar uma dinâmica democrática sustentada em instituições confiáveis.

Paralelamente, os antigos aliados do Mops nas instituições estatais foram deslocados, ocorrendo graves mudanças na condução das políticas de saúde. Essas mudanças sinalizaram um desinvestimento na estrutura e no funcionamento dos serviços, que começaram a decair, com a falta de equipamentos, medicamentos e leitos. Também os médicos e funcionários se afastaram das unidades de saúde, devido à deterioração de seus salários.

Em tal conjuntura, observamos que o MAB, por um caminho diverso do da Famerj, entrou também em fase de desmobilização, o que o levou a se distanciar da cena política. Naturalmente, o MAB tinha uma expectativa importante a respeito do financiamento estatal do Pesb, mas o abandono do projeto, em lugar de estimular a resistência política, deixou a entidade inerte.

Nessa situação, as diferenças políticas no interior do movimento popular voltaram novamente à tona, e as discussões de caráter político-ideológico passaram a ser o eixo do Mops. Assim, a falta de atuação e de mobilização em 
defesa da efetiva implementação da Reforma Sanitária foi suplantada pela ação 'para dentro' e esta levou progressivamente a um esvaziamento do mesmo.

Uma nova crise no setor, porém, possibilitou uma vez mais a postergação das diferenças internas no encaminhamento conjunto do Mops. Houve, fundamentalmente, um ponto de encontro importante entre o movimento popular e o movimento médico, particularmente pela atuação do Cremerj, que fez uma convocação, no fim de 1989, para a luta conjunta em defesa da política reformadora de saúde.

Desse modo o Mops voltou a estar presente na cena política, exigindo a intervenção do Estado através de medidas regulatórias que aliviassem a situação de pane em que tinham se envolvido os hospitais do município e da Previdência Social no estado do Rio de Janeiro.

As crises no setor saúde foram desencadeadoras da organização e da atuação do Mops, fossem elas alimentadas pela inoperância e pela ineficiência do sistema de saúde, fossem pelas graves epidemias que afetavam reiteradamente a população, especialmente as camadas mais pobres.

Consideramos que tais crises se situavam no campo das necessidades sociais básicas. Elas foram um mecanismo de disparo em múltiplas direções, devido à ameaça que representavam à estabilidade relativa dos sistemas produtivos e à ordem social mínima que os mesmos requeriam para se reproduzirem, ou, ainda, devido à epidemia ou à impossibilidade de o sistema de saúde conseguir prestar assistência aos doentes. Tratava-se, em ambos os casos, da 'doença sofrida de maneira coletiva', ou, dito de outra forma, de uma situação na qual a população se via obrigada a usufruir de um 'mal público'.

Por fim, a trajetória do Mops mostrou que sua atuação foi profundamente marcada pela presença insuficiente do Estado ou por sua ausência de intervenção na situação de saúde da população. No entanto, ainda que o Estado tivesse falhado estrategicamente na consecução desse objetivo, havia uma dinâmica constitutiva e constituinte na relação dos movimentos populares com ele.

No caso, os movimentos reagiram a sua omissão se articulando e desencadeando a ação coletiva que lhes proporcionou existência concreta, o que por sua vez obrigou então o Estado a tomar algum tipo de iniciativa intervencionista.

Em conseqüência, observamos que no momento em que o Movimento Popular em Saúde tentou resolver a contradição com o Estado, desconhecendo a existência deste - isto é, eliminando um dos termos da contradição -, sobreveio a paralisia política. 
A eliminação do Estado não passou de discurso da 'facção radical do movimento'. De fato, não só o Estado continuou existindo, mas o 'feitiço virou contra o feiticeiro'. A resultante desse procedimento foi a exclusão de seus interlocutores políticos: os organismos estatais da saúde, o movimento sanitário qualificado como dos 'tecnocratas da saúde' e, por último, aquela parte que conservava uma posição política diversa.

Pode-se afirmar então que o Mops teve papel principal no encurtamento da distância entre a esfera privada - social - e a esfera pública - ordem política -, incidindo marcadamente na formulação das políticas de saúde. Contudo, apesar das diferenças internas do movimento em relação à Reforma Sanitária, os avanços que esta alcançou se devem em grande parte ao papel que a mobilização popular e as lideranças exerceram, pressionando o Estado a atuar em tudo o que se relaciona às condições de saúde da população.

Acreditamos, assim, que, no difícil percurso da democracia brasileira, o papel que o Mops possa vir a desenvolver seja determinante na implementação da Reforma Sanitária. 


\title{
0 Movimento Médico: composição e trajetória (1976-1990)
}

\begin{abstract}
A denominação Movimento Médico, conferida à atuação do conjunto das entidades médicas, obedeceu ao leque de atribuições, atividades e aspectos diversos que estas comportavam: a representação sindical, a regulação da profissão médica e a reprodução, informação e difusão da informação técnicocientífica. É preciso ressaltar ainda que durante o período estudado - 19761990 - a atuação das entidades médicas foi complementada por formas de atuação política que se constituíram numa modalidade particular de representação dos interesses médicos.

As características das entidades médicas, o importante grau de institucionalização das associações e as diversas modalidades de sua atuação - cuja trajetória será considerada neste capítulo -, possibilitarão compreender a enorme distância existente entre estas e as entidades que compuseram o Movimento Popular em Saúde, assim como também sua inclusão dentro do que consideramos Movimento Social em Saúde.

Inicialmente, foi possível constatar a existência de uma certa indiferenciação nas funções desempenhadas pela Sociedade de Medicina e Cirurgia do Rio de Janeiro (SMCRJ) e pela Sociedade Médica do Estado do Rio de Janeiro (Somerj), duas entidades de caráter privado, sem vinculação com o estado e com atividades voltadas para o terreno técnico-científico, onde aliás a SMCRJ tem reconhecida tradição. Filiadas à Associação Médica Brasileira (AMB), ambas seguiram linhas políticas similares a esta, tendo, portanto, grande penetração nas correntes médicas ditas neoliberais, notável nos últimos anos da década de 80, constituindo-se, também, em importantes centros de defesa do corporativismo médico.

À Somerj filiavam-se entidades de âmbito municipal, não sendo esta filiação de caráter compulsório. Quanto à diretoria, era eleita diretamente pelo voto de
\end{abstract}


todos os associados a ela filiadas. Em 1983, por exemplo, foram em número de 20 as entidades que se filiaram, tendo esse total se elevado para 28 em 1989. Essa filiação era feita de forma individual ou através das sociedades filiadas conveniadas, contando com 4.060 filiados em 1983 e com 6.530 em 1989.

Em relação ao Conselho Regional de Medicina (Cremerj) e ao Sindicato dos Médicos (SinMed), eram entidades vinculadas ao estado através do Ministério do Trabalho. Tinham, portanto, funções definidas por este, e contavam, como se sabe, com uma legislação corporativa. Todavia, ainda que estivessem inseridas na estrutura corporativa estatal, desempenharam importante papel político na defesa do sistema público de saúde voltado ao atendimento das populações necessitadas.

Considerando-se o controle exercido pelo estado sobre o Cremerj e o SinMed, as funções que estas assumiram em defesa da categoria podem ser consideradas conquistas efetivas, oriundas das diretrizes políticas assumidas a partir do final da década de 70 e durante a década de 80 .

As funções de caráter institucional atribuídas ao Cremerj eram dirigidas à regulação e à supervisão da prática médica. A eleição do Conselho, realizada diretamente por médicos credenciados, com exceção dos que eram militares, ocorria de cinco em cinco anos. A diretoria era indicada anualmente pelo Conselho. Em 1983, o Cremerj contava com 28.889 filiados e em 1989 com 37 mil.

Com relação ao SinMed, qualquer médico diplomado é admitido. Sua diretoria era eleita a cada dois anos por todos os médicos com pelo menos seis meses de filiação e diplomados há mais de dois anos. Enquanto em 1983, o número de filiados era de 7 mil, em 1989 aumentou para 13.800.

O Cremerj esteve sob intervenção do Conselho Federal de Medicina (CFM) no período compreendido entre 1978 e 1983,38 após o qual vem elegendo diretorias bastante homogêneas no que tange à sua posição crítica ao sistema de saúde vigente, defendendo as propostas de unificação do sistema de saúde sob responsabilidade do Estado.

No plano específico da categoria médica, essas diretorias eram também bastante críticas quanto aos interesses de caráter individualista, privatista e corporativista, que se tornaram mais fortes a partir do fim da década de 80. Desse modo, a entidade teve um destacado papel na busca de contato mais

\footnotetext{
38 A intervenção no Cremerj obedeceu ao fato de que a chapa Renovação e Unidade, formada por profissionais afinados com a concepção de reformulação do sistema de saúde, ganhou as eleições com mais de $75 \%$ dos votos e em aberta oposição ao regime militar e ao Ministério do Trabalho.
} 
estreito com o Movimento Popular em Saúde. É importante ressaltar que essa homogeneidade na condução política da entidade poderia estar relacionada à baixa rotatividade na composição do Conselho, renovada a cada ano.

É provável que o SinMed tenha sido a entidade que mais se manteve fiel às funções de representação dos interesses profissionais dos médicos estabelecidos legalmente no período estudado, enquanto a SMCRJ, a Somerj, e mesmo o Cremerj estenderam em muito suas funções originais, definidas estatutariamente, chamando para si a tarefa de defesa dos interesses da categoria e da participação na discussão dos destinos da área de saúde no País.

Ainda que sob orientações políticas diversas e em diferentes graus, observamos que o SinMed priorizou, a partir de 1983, a atuação no terreno estritamente sindical, diferentemente do período compreendido entre 1976 e 1983 . Neste, a entidade havia se tornado a liderança política hegemônica da categoria médica, conduzindo a discussão política do setor saúde no estado do Rio de Janeiro.

A mudança na atuação do sindicato deveu-se a uma reorientação de caráter corporativo nas chapas sindicais, sem que tivesse havido alterações na conformação das diretorias nos anos recentes, já que estas eram compostas praticamente pelas mesmas pessoas que delas faziam parte no período 'áureo' do sindicato.

A diversidade de associações que articulavam a categoria médica e a variação da atuação, tanto política como profissional das mesmas, apontaram algumas reflexões teóricas iniciais a respeito do papel dos médicos e de suas entidades no processo de formulação e implementação das políticas de saúde, a serem exploradas no transcorrer deste capítulo.

A denominação Movimento Médico não parece inteiramente ajustada à maneira clássica em que têm sido compreendidos os movimentos sociais. As formas de articulação profissional assim como a atuação dos médicos e das instituições de assistência médica em relação às políticas de saúde e ao Estado sofreram importantes variações no período estudado.

Em relação à composição, o Movimento Médico foi multifacetado, incluindo as várias associações profissionais e uma relação orgânica dos seus membros na defesa de interesses corporativos da classe médica. Assemelha-se bastante às antigas corporações e conta com uma unidade e com um sprit the corp comparável à corporação militar. Formada por diversas entidades dotadas de larga existência, com funções bem diferenciadas nos vários planos em que se desenvolve a vida do profissional médico. 
No que concerne à sua atuação, o Movimento Médico demonstrou ser bastante complexo. Na década de 70, particularmente em seus derradeiros anos, as associações médicas tiveram uma atuação política especialmente intensa, o que justifica amplamente a denominação 'movimento médico'. Não se pretende afirmar que ela tenha sido exclusiva, muito pelo contrário. O que se quer frisar é que foi predominante, tendo ocupado o segundo plano a atuação de caráter profissional e/ou sindical dos médicos. No entanto, a década de 80 acentuou a face reversa da atuação médica, marcada pela atuação profissional e corporativa dos médicos e expressa também, em graus diversos, pelo conjunto das entidades médicas.

Dois eixos temáticos parecem de importância singular para a análise da atuação da categoria em relação às políticas de saúde:

- a corporação médica;

- a representação dos interesses médicos ante as políticas de saúde do Estado.

A corporação médica é composta por algumas instituições datadas do século passado, como é o caso da SMCRJ e da Associação Médica Brasileira (AMB). Elas se sustentaram sobre um código de exercício da profissão médica fortemente compartilhado e respeitado pelo conjunto da categoria, envolvendo: sigilo profissional; liberdade de eleição do assistente por parte do paciente; liberdade de prescrição; autonomia do trabalho médico; pagamento direto da consulta médica (Caro, 1969).

Essas questões conformaram o ideário médico em torno do exercício liberal da medicina. No entanto, o pertencimento à corporação não implicava nem a existência de uma organização hierarquizada, nem a obrigatoriedade no cumprimento de regras de comportamento estabelecidas pela corporação, exceto as que se referiam ao Código de Ética Médica e que regulamentavam o exercício da profissão sem interferirem na relação dos médicos com as associações.

Ainda que esses princípios tenham perdido vigência ou então se adequado às mudanças no sistema de saúde e conseqüentemente ao processo de trabalho e de exercício da profissão médica, nos últimos 20 anos, outorgavam unidade e identidade à categoria. Neste sentido, diferentemente de qualquer outra profissão liberal, a unidade e identidade de princípios - existência de um código médico - fizeram da categoria médica um tipo singular de 'corporação'.

A primeira conseqüência ao se considerar a categoria médica como corporação é a de não aceitação de regras externas à mesma na definição de 
padrões de intervenção terapêuticos, processos de trabalho e remuneração. Significa que os processos de adaptação às mudanças nas políticas de saúde basicamente a mercantilização da medicina, a perda da autonomia e o assalariamento médico - acarretaram forte resistência no que diz respeito às tentativas de defesa do ideário da medicina liberal.

Apesar de haver mudado a inserção profissional desde o exercício liberal da medicina ao assalariamento, o médico continuou a se considerar possuidor do poder que lhe conferiu o saber e que se mantém, ao longo do tempo, resguardado de interferências alheias à relação médico-paciente.

Um dos traços significativos da política de saúde, na década de 70, está relacionado à privatização e à capitalização do setor, sustentado pelo modelo da medicina previdenciária, o que teria provocado profundas mudanças no tipo de inserção profissional dos médicos. A acumulação capitalista desse setor - número mais elevado de intervenções médicas significou crescimento desmedido dos lucros do setor privado conveniado com a Previdência Social - fez-se acompanhar de profundas mudanças na inserção profissional do médico. Houve massificação do trabalho médico assalariado do setor público/privado, tendo estes mantido simultaneamente formas paralelas de inserção no mercado de trabalho, seja como profissional liberal, autônomo ou proprietário de clínicas ou hospitais (Donangelo, 1984).

Em 1970, por exemplo, o setor de assistência médico-hospitalar empregava 44,8\% dos médicos, enquanto em 1980 já empregava 62\% dos que se encontravam em atividade. A porcentagem destes em relação aos que trabalhavam de maneira autônoma se ampliou durante o período: em 1970, foi registrado $65,35 \%$ de médicos empregados e 32,05\% de autônomos, ao passo que em 1980 esse índice se elevou para 67,33\% de empregados e conseqüentemente caiu para 24,58\% de autônomos (Medici, 1987). ${ }^{39}$ No transcorrer da mesma década, o salário do médico empregado sofreu importante diminuição, tal como ocorreu com as demais categorias profissionais.

De acordo com Medici (1987), essa redução de rendimentos médicos, ou sua 'proletarização', pode ter ocorrido em virtude da redução do padrão salarial, e não pela redução da renda real. Isso pode ser explicado pela múltipla inserção desses profissionais. Dito de outro modo, tais mudanças obrigaram os médicos a ter dois ou três empregos, a fim de evitar o empobrecimento. Todavia,

39 A porcentagem restante nas duas datas consideradas corresponde, na tabela original, à categoria 'outros setores'. Planejamento I. Recursos Humanos em Saúde. RI: Textos de Apoio. PEC-Ensp/ Fiocruz, 1987. 
essa múltipla inserção resultou na depreciação da atividade - falta de tempo para estudar, diminuição da responsabilidade médica no local de trabalho, crescimento dos erros médicos - e, também, na extensão das lutas salariais da categoria.

Por conta disso, o trabalho médico na área assistencial ou previdenciária inclinou-se à tendência em se tornar cada vez mais especializado, a relação médico-paciente foi intermediada pela instituição e a utilização da tecnologia médica intensificou-se, assim como a medicalização. De fato, ocorreu uma perda da autonomia dos médicos no processo de trabalho, o que afetou os próprios princípios da medicina liberal, visto que as instituições assistenciais passaram a interferir diretamente no trabalho do médico.

A resistência dos médicos às transformações no processo de trabalho, ao assalariamento maciço e à proletarização da categoria não se fez esperar. Já na metade da década de 70 a corporação médica, nucleada em torno da chapa Movimento de Renovação Médica (Reme), que vinha conquistando as direções das entidades médicas, começou a ter singular importância no âmago da categoria médica.

Ainda que o Reme tivesse nítida orientação de esquerda, adquiriu penetração nas instituições médicas e iniciou um movimento de oposição, de caráter político e sindical, ao regime militar. Devido principalmente à atuação política das entidades médicas, com o apoio conjunto da categoria, as instituições médicas sofreram fortes pressões do regime militar que, no caso do Cremerj, designou uma junta interventora do Ministério do Trabalho para destituir as direções eleitas por seus membros em 1978.

A representação de interesses da categoria médica requer discussão adicional. E surge a interrogação: pelo fato de a categoria médica ter uma estrutura organizacional assemelhada às antigas corporações, poderíamos deduzir que ela defende seus interesses apenas sob uma modalidade corporativa?

A representação de interesses dessa maneira corporativa implicaria necessariamente o controle de seus membros, por parte das entidades médicas, sobre seus membros e, também, a institucionalização de certos canais formais de relacionamento com o Estado nos processos de formulação de políticas. Diferentemente, a reformulação do sistema de saúde resultou das pressões políticas conjuntas das associações médicas, dos movimentos populares e do Movimento Sanitário, onde um processo de acumulação de forças sociais e de luta no terreno político, com um projeto definido para o setor saúde junto de uma 
definição estratégica, impôs profundas reformas ao Estado no campo das políticas de saúde.

Poder-se-ia interpretar a forte reação política da corporação médica como provocada pelos interesses médicos afetados pelas políticas de saúde do regime autoritário. Todavia, não existiu no período nenhum canal institucionalizado, por parte do Estado, para representação dos interesses médicos.

Acreditamos, portanto, não ser conveniente pensar a representação de interesses médicos na década de 70 como sendo de caráter corporativo (Castro, 1989), nem que o poder e a identidade da corporação médica encontrava 'suporte material' na produção de equipamentos, insumos, medicamentos e fármacos (Vianna, 1987). Tal observação seria válida enquanto tendência geral na constituição do poder médico, mas é inadequada ao se referir ao processo que atravessou a categoria médica na mencionada década.

Muito ao contrário, enquanto a identidade da corporação médica se baseou nos princípios da medicina liberal, as transformações do sistema previdenciário de saúde, na década de 70 , mudaram profundamente o processo de trabalho médico, levando a categoria a enfrentar a política de saúde dominante.

De fato, a medicina previdenciária sustentada na assistência hospitalar e no complexo médico-industrial (tecnologia e fármacos) levou a amplas mudanças na relação médico-paciente, no processo de trabalho e no papel social do médico, tudo isso sob grande resistência dos médicos.

Após essas considerações, caberia distinguir as formas de representação de interesses, assim como fazer uma nova leitura teórica sobre as modalidades da corporação médica em representar os interesses da categoria, já que estas modalidades mudaram no período aqui analisado.

Poderíamos nos aproximar de uma definição de representação de interesses a partir da idéia da associação de pessoas que têm uma ou várias características comuns ao conjunto das mesmas e que aspiram a influenciar nos processos de políticas específicas que estejam relacionadas com aquilo que é comum ao grupo de interesse.

De maneira geral a bibliografia sobre o tema - consultar Schmitter (1992) e Offe (1989) - estabelece uma primeira grande distinção entre a representação plural de interesses e a representação corporativa. Schmitter (1992) afirma que no pluralismo o tipo de determinação de interesses é múltiplo, disperso, nãohierárquico e voluntário, enquanto no caso do corporativismo se trata de uma 
modalidade de determinação de interesses que é basicamente singular, concentrada, funcionalmente diferenciada, hierárquica e obrigatória. ${ }^{40}$

A notável síntese elaborada por Schmitter corresponde a 'tipos ideais' de representação de interesses. De fato, a relação entre intermediação de interesses e modos de formação de políticas adquire especificidade segundo os países e de acordo com processos histórico-políticos singulares, o que necessariamente implica gradações diversas no exercício real da representação de interesses que podem, por vezes, aproximar-se ou distanciar-se desse 'tipo ideal'.

Offe (1989) acrescenta quatro dimensões do conceito de corporativismo relacionadas ao status formal dos grupos de interesse:

- 'status de recursos' - quando o Estado provê de recursos as organizações de representação de interesses-subsídios, isenções fiscais, filiação compulsória, acesso aos meios de comunicação controlados pelo Estado;

- 'status de representação' - quando o alcance da representação é definida pelo Estado - áreas em que esta pode operar, região, número de filiados, posição;

- 'status de procedimento' - quando são reguladas as relações internas entre membros e direções;

- 'status de procedimento' - quando as organizações são reconhecidas para assumir, junto a um conjunto específico de participantes, um papel na legislação, no sistema judiciário, no planejamento e na implementação de políticas. Isso é definido em contraposição a relações de cooperação informal. Trata-se, portanto, de um status definido por lei ou de regras de procedimento formalmente adotadas.

Tanto na compreensão de Schmitter como na de Offe a representação corporativa de interesses supõe alguma forma de 'concertação' na formulação da política. Constitui uma das várias formas de se resolver nas sociedades de democracia avançada o conflito entre uma multiplicidade de interesses e a ameaça

40 "el tipo de determinación de interés 'múltiple, disperso, no jerárquico y voluntario' - es decir, el pluralismo -, y el tipo singular, concentrado, diferenciado funcionalmente, jerárquico y obligatorio: es decir el corporativismo. Una hipótesis obvia es que existe una compatibilidad estructural o afinidad selectiva entre el comproativismo y la concertación y entre el pluralismo y la presión (...). En el primero, los intereses afectados, por muy organizados que sean quedan incoporados al proceso político como negociadores reconocidos e indispensables y son corresponsables (y en ocasiones totalmente responsables (y em ocasiones totalmente respnsables) de la aplicación de las decisiones políticas, que entonces adoptan una calidad caracteristicamente semipública o paraestatal. En la última los interesses afectados quedan esencialmente fuera del proceso politico, como consultores o combatientes en las cuestiones que se trate, y la aplicación ocurre exclusivamente bajo la responsabilidad de las autoridades públicas, por muy influenciadas que puedan estar por las acciones autónomas de los intereses organizados en el curso de sus actividades" (Schmitter, 1992). 
freqüente de polarização dos mesmos, que pode conduzir à ingovernabilidade. Trata-se de uma maneira de canalizar os interesses que não leve as forças sociais e os governos a um jogo de soma zero.

Se observarmos a corporação médica sob tal perspectiva, podemos então refletir sobre a distinção aqui considerada. Por um lado, ela é composta por diversas entidades, das quais unicamente duas têm status público - o Cremerj e o SinMed. São reconhecidas pelo Estado, mas de seu controle - que caracterizara a década de 70 - conseguiram se desvencilhar, a partir dos anos 80, com o avanço do processo de democratização do País, tendo então adquirido forte autonomia,

Por outro lado, as demais entidades - AMB, Somerj, SMCRJ -, de caráter privado, ainda que institucionalizadas e regulamentadas quanto aos procedimentos internos - composição das diretorias, eleições periódicas, cursos e outras atividades de caráter científico -, não possuem status público. Historicamente, exerceram o papel ideológico de aglutinar os médicos sob aqueles princípios tradicionais da medicina, oferecendo-lhes atualização científica. Também exerceram o papel de representação dos interesses médicos quando ameaçados pela intervenção do Estado ou quando afetados por políticas específicas.

Com relação à representação dos interesses médicos, fizemos referência a dois momentos bem diferenciados na atuação dos médicos. Um primeiro na década de 70 , em que a atuação médica teve um componente precipuamente político de oposição à ditadura militar, às políticas de saúde implementadas naquele período e à intervenção militar nas entidades médicas.

Em conseqüência da oposição a essa intervenção, sobretudo, houve imediata solidariedade das outras entidades, além de uma atuação conjunta com a característica de ser pluralista, inorgânica e de pressão política sobre o regime militar. Neste sentido, o processo de reformulação do sistema de saúde foi o resultado da imposição das forças sociais em saúde, entre estas o Movimento Médico, que, através de uma representação de interesses de caráter pluralista, colaborou na produção de mudanças concretas no delineamento das políticas de saúde.

Um outro momento, referente à segunda metade dos anos 80 , caracterizado pelo avançado processo de democratização do País, teve como eixo no setor saúde - em 1988 a Reforma Sanitária foi estabelecida na Constituição - a implantação do novo modelo político-sanitário, que embora obtendo o apoio da maioria envolvida com esse setor necessitava ainda passar do papel à realidade.

O projeto não se concretizou até hoje, alternando avanços e retrocessos atribuíveis, por um lado, às dificuldades do processo e, por outro, ao fato de ser 
justamente o momento da implementação, quando a diversidade dos interesses médicos, relativos às diversas formas de inserção da categoria médica no mercado de trabalho, incrementou ainda mais as dificuldades no andamento da Reforma Sanitária.

Nesse aspecto, registramos notáveis transformações na atuação do Sindicato Médico em direção à representação corporativa dos médicos, que não chegou a ser institucionalizada e que, conseqüentemente, não se encaminhou a um modelo de 'concertação' de políticas. A atuação do SinMed se aproxima, ainda que não completamente, ao modelo italiano de relações entre Estado e sindicatos em que se estabelecem formas de colaboração pelas quais representantes sindicais participam em organismos públicos ou em 'juntas de diretores', mesmo que as consultas na formação da política sejam de caráter informal e constante (Regini, 1992). No caso do SinMed, apenas algumas vezes houve consultas informais entre governo e sindicato, como no concurso público no Hospital da Posse, a ser discutido adiante.

A combinação das tipologias analisadas possibilitará estabelecer relações entre modalidades de representação de interesses e tipo de organização das entidades médicas no período considerado, visualizadas a seguir:

Quadro 5 - Representação de interesses e tipos de organização médica, 19761986

\begin{tabular}{|ccc|}
\hline $\begin{array}{c}\text { Representação de } \\
\text { Interesses }\end{array}$ & Status Público & Status Privado \\
\hline Plural & SinMed-Cremerj & Somerj-SMCRJ \\
Corporativa & - & - \\
\hline
\end{tabular}

Quadro 6 - Representação de interesses e tipos de organização médica, 19861992

\begin{tabular}{|ccc|}
\hline Representação de Interesses & Status Público & Status Privado \\
\hline Plural & Cremerj & - \\
$\begin{array}{c}\text { Corporativa } \\
\text { (não-institucional em } \\
\text { relação ao Estado) }\end{array}$ & SinMed & Somerj-SMCRJ \\
\hline
\end{tabular}


Se nos Quadros 7 e 8 considerarmos as relações entre representação de interesses, formação de políticas e tipo de organização médica, observaremos que em nenhum dos períodos examinados houve 'concertação' da maneira como esta foi compreendida pela reflexão teórica mais recente sobre o corporativismo, discutida anteriormente.

Quadro 7 - Representação de interesses, formação de políticas e tipos de organização médica, 1976-1986

\begin{tabular}{|c|cc|cc|}
\hline \multirow{2}{*}{$\begin{array}{c}\text { Representação de } \\
\text { Interesses }\end{array}$} & \multicolumn{2}{|c|}{ Pressão } & \multicolumn{2}{c|}{ Concertação } \\
\cline { 2 - 5 } & Status Público & Status Privado & Status Público & Status Privado \\
\hline Plural & SinMed & Somerj-SMCRJ & - & - \\
Corporativo & Cremerj & & - & - \\
& - & - & - & - \\
\hline
\end{tabular}

Quadro 8 - Representação de interesses, formação de políticas e tipos de organização médica, 1986-1992

\begin{tabular}{|c|c|c|c|c|c|}
\hline \multirow{2}{*}{$\begin{array}{l}\text { Representação de } \\
\text { Interesses }\end{array}$} & \multicolumn{2}{|c|}{ Pressão } & \multicolumn{3}{|c|}{ Concertação } \\
\hline & Status Público & Status Privado & Statu. & s Público & Status Privado \\
\hline Plural & Cremerj & - & & - & - \\
\hline $\begin{array}{l}\text { Corporativo (não } \\
\text { institucional) }\end{array}$ & SinMed & Somerj-SMCRJ & & - & - \\
\hline
\end{tabular}

A tipologia de representação de interesses desenvolvida por Lange \& Regini (1987) relacionou interesses e instituições no processo de formação de políticas, ante a consideração do grau de exclusão/inclusão dos interesses organizados (apud Castro, 1989). No primeiro caso, a exclusão seria uma típica modalidade dos regimes totalitários; a inclusão corresponderia ao máximo grau de 'concertação' e resultaria na "delegação de funções públicas a governos privados" (Streek \& Schmitter, 1992).

Tal distinção permite considerar gradações ou diferenciações na inclusão/ exclusão dos interesses médicos na formação de políticas do regime autoritário e no processo de democratização. Isso remete à dificuldade em criar procedi- 
mentos políticos mais adequados de representação de interesses médicos no processo de implantação da Reforma Sanitária, dificuldade esta observada hoje no estabelecimento do regime democrático. Trata-se de obstáculo que se inscreve nas instituições estatais de saúde, especialmente na corporação médica.

Diferenciações ou gradações da representação de interesses da corporação médica estão relacionadas à diversidade de inserções profissionais dos médicos no mercado de trabalho.

Os médicos tanto do serviço público quanto do privado são trabalhadores assalariados, agrupados pelos sindicatos e em condições 'relativamente similares' às das demais categorias. Contudo, quando ocupam cargos técnicos ou de direção nos organismos estatais - sejam estes de aplicação de políticas ou de serviços de saúde -, fazem parte da tecnoburocracia de Estado, com autoridade e poder de decisão sobre a alocação de recursos, gestão e procedimentos do sistema de saúde, e também com interesses profundamente associados aos das instituições e políticas estatais.

Se considerarmos, agora, os médicos proprietários de clínicas e hospitais, notamos que representam os interesses do setor privado e que tiveram, no período do regime autoritário, influência na tecnoburocracia de Estado, através de mecanismos de pressão e orientação denominados de "anéis burocráticos" por Cardoso (1975).

A entidade que os representa é a Federação Brasileira de Hospitais (FBH), que congrega empresários da saúde. Todavia, na medida em que uma grande proporção de pequenas clinicas e hospitais são de propriedade de médicos e tendo em vista que a concepção desses proprietários, em termos de prática médica, não se distancia da categoria como um todo, acreditamos que devem ser considerados como uma das formas de inserção profissional dos médicos.

Por fim, a designação de 'médico liberal' ou 'autônomo' já não significa muito mais que uma categoria em extinção. Embora possa corresponder ao exercício médico no consultório privado, é uma modalidade quase desaparecida. Atualmente os médicos com consultório particular, em sua grande maioria, são conveniados com o setor privado. Nesse caso, a forma de representação de interesses se sustenta, mais que em qualquer outra forma de inserção profissional, na defesa dos princípios da medicina liberal. Essa modalidade oculta o assalariamento médico (sob a forma do exercício liberal da profissão, reduzida à formalidade conceitual). 
Do resultado dessa diferenciação ocupacional dos médicos, poderiamos estabelecer relações entre as modalidades de inserção profissional e o tipo de representação de interesses.

Quadro 9 - Tipo de inserção profissional e representação de interesses, 19761986

\begin{tabular}{|ccc|}
\hline Tipo de Inserção Profissional & Plural & $\begin{array}{c}\text { Corporativa } \\
\text { ('anéis burocráticos' ou } \\
\text { círculos de pressão) }\end{array}$ \\
\hline Assalariamento & Sim & Não \\
Liberal ou autônoma & Sim & Não \\
Tecnoburocracia & Não & Sim \\
Proprietário clínica/hospital & Não & Sim \\
\hline \hline
\end{tabular}

Quadro 10 - Tipo de inserção profissional e representação de interesses, 19861992

\begin{tabular}{|ccc|}
\hline Tipo de Inserção Profissional & Plural & $\begin{array}{c}\text { Corporativa } \\
\text { (não-institucionalizada) }\end{array}$ \\
\hline Assalariamento & Não & Sim \\
Liberal ou autônoma & Sim & Não \\
Tecnoburocracia & Sim & Não \\
Proprietário clínica/hospital & Não & Sim \\
\hline
\end{tabular}

A formação de políticas de democratização e de construção de uma institucionalidade democrática tendeu a ser exercida pela via da pressão política. Configurou-se uma situação na qual os atores sociais, cujos interesses haviam sido postergados no regime militar, almejaram a obtenção ou a compensação de benefícios, através da pressão popular, o que poderia inviabilizar a democracia, considerando que inexistia tradição de negociação, tanto no Estado quanto nas forças políticas conflitantes.

As diferenças políticas substantivas não faziam parte do jogo político, uma vez que o regime autoritário operara pela via da exclusão de interesses, conside- 
rados incompatíveis com seus lineamentos políticos e econômicos. A construção da institucionalidade democrática requereu a incorporação de mecanismos de negociação na decisão e na implantação de políticas, mas enfrentou dificuldades.

Por um lado, a ausência de uma prática de negociação política levou a que fossem considerados os mecanismos de pressão a única maneira de viabilizar interesses sem negociação entre as partes envolvidas. De fato, a possibilidade de incorporação de interesses estava diretamente relacionada à força política e aos recursos do grupo, sem modalidades preexistentes apropriadas à discussão entre as forças conflitantes e o governo. Nessa circunstância, os governos tendiam 'a dar a uns e a tirar de outros', conforme a intensidade da pressão e dos compromissos políticos em jogo.

Diríamos que o uso reiterado da pressão política dificulta a constituição de instituições estáveis, bem como de mecanismos de negociação política compatíveis com um governo democrático. Essa maneira de lidar com interesses conflitantes leva necessariamente à desestabilização política permanente, a não ser que o governo disponha de suporte político necessário para enfrentar o embate entre interesses através do reconhecimento e autoridade suficientes para conduzir, de maneira mais isenta, as negociações. Isso dificilmente poderia ocorrer com as características atuais da sociedade brasileira e do seu sistema político-partidário.

Criou-se, por outro lado, uma modalidade de formação de políticas combinada com uma maneira particular de exclusão/inclusão de interesses, via regime autoritário, que O’Donnell (1975:143) denominou "corporativismo bifronte e segmentado", o qual dificilmente pode ser expulso do domínio do Estado. Neste haveria ocupação do Estado por parte de grupos dominantes na sociedade grande capital e profissionais de alta renda -, sem a preocupação de mediar nem a representação corporativa de interesses nem formas de 'concertação' de políticas. Também haveria intervenção ou controle do Estado pela força ou através de legislação impeditiva do desenvolvimento de entidades da sociedade civil representativas de interesses "da classe operária ou de classes subalternas".

A primeira dessas formas de corporativismo instalou-se nos aparelhos institucionais do Estado e estabeleceu uma 'colonização' inversa àquela que Schmitter atribui ao neocorporativismo, ainda que, às vezes, com resultados semelhantes.

As greves dos médicos como única forma de canalizar os interesses da categoria se constituíram numa modalidade de competição política extremamente frágil, já que só se podia observar a exacerbação da representação 
corporativa da categoria à medida que seus interesses eram diretamente afetados pela política. Quando a política não os afetava, o que se observava era a omissão. Essas são questões a serem retomadas adiante.

\section{As Entidades Médicas e a Política de Saúde}

O objetivo deste tópico é analisar a atuação do conjunto das entidades médicas - que denominaremos de Movimento Médico - com relação à formação das políticas de saúde. As entidades médicas - fundamentalmente o SinMed tiveram atuação política destacada no processo de democratização do País no período de 1976 a 1986, propugnando por uma nova estrutura para o setor saúde, cuja maior expressão foi a VIII Conferência Nacional de Saúde, com a respectiva proposta de reformulação do sistema - a Reforma Sanitária brasileira.

Produziram-se amplas mudanças na atuação e no posicionamento político do Movimento Médico posteriormente a 1986, na fase de implementação da Reforma Sanitária. O comportamento político de oposição ao regime militar que caracterizou as entidades médicas na transição à democracia, assim como sua inserção no processo de reformulação do sistema de saúde, cedeu lugar a uma atuação dirigida à defesa dos interesses econômicos-corporativos dos médicos, ou seja, à revalorização do exercício liberal da profissão médica e à readequação das agendas e questões das entidades médicas - a seguir analisadas - aos novos rumos da política em anos recentes.

A organização temática desta seção terá como eixo a recuperação das questões relevantes na articulação política do movimento e de sua atuação no tocante às políticas de saúde. Ainda que o trabalho de pesquisa tenha dado ênfase ao período que se estende de 1976 a 1992, o ordenamento da exposição subdividiu-o em dois - um de 1976 a 1986, outro entre 1986 e 1992 -, para melhor visualização das diferenças na trajetória do movimento, desde seu surgimento até a década de 90.

O período compreendido entre 1976 e 1986 foi marcado pela presença política do Movimento Médico tanto nas lutas específicas da categoria pelos direitos trabalhistas quanto nas críticas ao Sistema Nacional de Saúde vigente à época, e também pela participação dos médicos no processo de democratização do País.

O movimento começou a tomar corpo com a criação da chapa denominada Movimento de Renovação Médica (Reme), formada por médicos do Rio 
de Janeiro e de São Paulo com vistas a concorrer às eleições de todas as associações médicas. Alcançou influência política na categoria a partir de 1977, quando venceu as eleições do sindicato dos médicos no estado do Rio, da Sociedade de Medicina e Cirurgia do Estado do Rio e da AMB, e se expandiu para a maioria dos estados brasileiros.

Uma vez consolidado, o Movimento Médico levou adiante a luta política pela democratização em oposição ao regime militar, influenciando intensamente as associações profissionais de classe média que proliferavam nas grandes cidades do País. No que tange à luta sindical dos profissionais de saúde, o Reme liderou as greves dos médicos e residentes, tendo estas se expandido consideravelmente em todo o território nacional a partir de 1978, reivindicando melhores salários, redução da carga horária e melhoria das condições de trabalho.

A intensa mobilização nesse período decorria, na realidade, das modificações realizadas na área da saúde, as quais haviam acarretado um assalariamento generalizado da categoria médica, fazendo com que esses profissionais, tradicionalmente liberais, acorressem massivamente ao vínculo empregatício no setor público/privado da saúde.

Desse modo, o Reme interpretava as dificuldades da categoria resultantes das novas formas de inserção profissional, tendo utilizado as greves e o fortalecimento do sindicato como instrumento de luta e de reivindicação das demandas médicas. Apresentou-se como defensor dos médicos assalariados propugnando formas de luta e de atuação típicas destes. Procurou, simultaneamente, transcender as lutas de cunho corporativo ao mobilizar a categoria tanto para a reformulação do Sistema Nacional de Saúde como para a participação nas lutas mais gerais pela democratização do País.

Com essa política, questionava-se o ideário tradicional de 'autonomia' do médico de consultório, vigente na medicina brasileira, ideário este hegemônico nas instituições médicas da época. Essa era a questão mais polêmica que permeava o exercício da prática médica e que outorgava identidade à corporação médica, independentemente das mudanças que se produziram no processo de trabalho médico.

O Reme transformou-se, assim, em vertente do Movimento Sanitário. ${ }^{41}$ Este era formado por intelectuais, sanitaristas, médicos e outros profissionais

41 Ainda que este trabalho não inclua o Movimento Sanitário como objeto específico de análise, fazemos freqüentes referências às relações entre o Movimento Popular em Saúde e o Movimento Médico com o Movimento Sanitário, na medida em que tais relações nos possibilitam compreendêlos melhor. 
da saúde coletiva, os quais se caracterizavam por práticas políticas, teóricas e ideológicas que enfocavam a questão da saúde como questão mais ampla, relacionada ao âmbito da sociedade e da política (Escorel, 1992).

Seu projeto era sustentado em uma ampla crítica ao modelo prevalente, baseado no crescimento do setor privado, através do financiamento pelo setor público, o que levou o sistema público de saúde à falência, deterioração, ineficiência e crise (Oliveira \& Fleury, 1984). Propunha a reversão do modelo, traçando uma estratégia fundamentada em propostas alternativas para o setor, as quais tiveram uma relativa penetração nos aparelhos estatais de saúde, ao passo que progredia o processo de democratização do País.

Durante esse período o Reme conseguiu notável desenvolvimento em todas as entidades médicas. Em 1978 venceu as eleições também no Cremerj. Porém, a vitória não foi sancionada pelo Conselho Federal de Medicina, dirigido desde 1957 por um grupo conservador caracterizado pela omissão diante de assuntos ligados à política de saúde, como também pelo caráter autoritário de suas decisões, sempre tomadas sem qualquer consulta ao conjunto dos médicos. De 1978 a 1983 o Conselho foi dirigido por uma junta interventora, o que significou a completa desinformação quanto aos assuntos referidos à Ética Médica, atividade prioritária do Conselho, além de não apresentar condições de julgamento dos médicos por infrações éticas, visto não possuir diretoria eleita.

O quadro modificou-se em 1983, quando o Tribunal Federal do Trabalho reconheceu a situação de irregularidade quanto ao impedimento da posse da chapa vencedora e decretou a realização de novas eleições. A chapa ligada ao Reme, denominada Renovação e Unidade, obteve $75 \%$ dos votos e os resultados tiveram de ser aceitos pelo CFM, que então já não possuía o espaço político anterior devido ao avanço do processo de democratização.

Diversas entidades médicas - a AMB, o CFM, a Somerj, a SMCRJ - também foram conquistadas pelo Reme, o que possibilitou a unidade na atuação das associações médicas. Mas o SinMed foi sem dúvida a entidade que melhor expressou a ascensão do Movimento Médico no estado, tendo se constituído em uma das principais entidades da sociedade civil de oposição e de luta contra a ditadura militar, junto com a $\mathrm{OAB}$, a $\mathrm{ABI}$ e outras.

O Sindicato dos Médicos teve atuação marcante no período. Liderou a categoria em grandes mobilizações pela democratização do País e pelas condições de exercício da prática médica. Esse papel se explica pela capacidade que 
teve, na época, de agrupar os médicos, de fazer uma releitura dos interesses da categoria a partir das transformações que tinham lugar no mercado de trabalho e de abrir um espaço político para o surgimento do Reme.

Sua plataforma baseou-se, precisamente, na defesa dos médicos assalariados, na renovação das linhas políticas das entidades médicas - fortemente premidas pelo regime autoritário -, e na luta por mudanças políticas em prol da democratização do País.

Entre 1977 - ano da primeira diretoria do Reme no Sindicato - e 1983, triplicou-se o número de associados pelo Sindicato, o que mostra sua decisiva penetração na categoria médica e o fato de ter sabido aproveitar o espaço político que o Cremerj deixou vazio, por estar sob intervenção do Ministério do Trabalho.

Em um dos primeiros números do jornal do SinMed, na gestão do Reme, a diretoria do Sindicato reivindicou os princípios da "ética hipocrática da medicina", com relação à dignidade e à honra no exercício da medicina, esquecidos em nome do caráter mercantilista, comercial e privatizante que o setor saúde adquiriu com o desenvolvimento capitalista das últimas décadas. Afirmava-se que "a privatização e o empresariamento da área de saúde, a existência do mercado e o afã de lucro desqualificam o médico como profissional e o paciente enquanto usuário". É interessante ressaltar que essa questão foi abandonada pelo Sindicato após 1986.

Quanto ao processo político geral pós-83, o Movimento Médico teve, através de suas entidades, participação direta na campanha pelas Diretas Já e pelo estabelecimento de uma Assembléia Nacional Constituinte. Para tanto, além de instalar uma Comissão de Eleições Diretas que coordenou as atividades da entidade e das demais associações médicas nessa campanha, o Cremerj deu início, também, a um programa de fóruns, abertos à categoria e à sociedade, sobre questões ligadas aos problemas da prática médica. Com isso aumentou, paulatinamente, a consciência da necessidade de modificação no sistema de saúde através de maior participação da categoria.

Os temas considerados nos fóruns exemplificam os eixos da atuação política do Movimento Médico durante esses anos e tinham como fim repensar a própria prática médica e influenciar nos rumos da política de saúde do País: Controle da Natalidade, Doenças Infecciosas e Parasitárias, Ensino Médico e temas de caráter mais político, tais como: Serviços de Saúde e Reforma Sanitária, Código de Ética Médica e Processo Constituinte. 
Das outras entidades médicas, vale destacar a Sociedade de Medicina e Cirurgia do Estado do Rio de Janeiro, que teve papel fundamental na reorganização da Associação Médica Brasileira, com a qual organizou o I Congresso Brasileiro de Entidades Médicas.

Esse congresso contou com a participação de dois mil médicos e discutiu desde temas médicos específicos até a Política Nacional de Saúde. Todas as entidades médicas estiveram presentes e, também, representando as cooperativas de trabalho médico a Confederação Nacional das Unimeds, à qual coube as discussões sobre mercado de trabalho.

As cooperativas médicas, na época, foram consideradas uma alternativa à mercantilização da medicina. Na verdade, tratava-se de uma tendência do Movimento Médico que a SMCRJ vinha defendendo, em todos os documentos da associação, desde 1971. Contudo, tal questão tendeu a desaparecer no transcorrer da década. As cooperativas médicas acabaram se transformando em empresas privadas de seguros de saúde, ao mesmo tempo em que começaram a avultar as concepções neoliberais de exercício da medicina.

Ilustramos, com o quadro a seguir, as principais características do Movimento Médico nesse período.

Faremos, ato contínuo, uma análise da atuação do Movimento Médico no período de 1986-1992, tendo por base a agenda de questões consideradas pelas diversas entidades selecionadas, a maneira pela qual foram tratadas e as transformações políticas que se produziram internamente nas próprias associações médicas. A ênfase dessa análise recairá nas questões a seguir, incorporadas à agenda das associações: a Ética Médica, a relação com o Estado e o processo constituinte, as greves e o corporativismo médico, os convênios com o setor privado e o exercício liberal da medicina. 


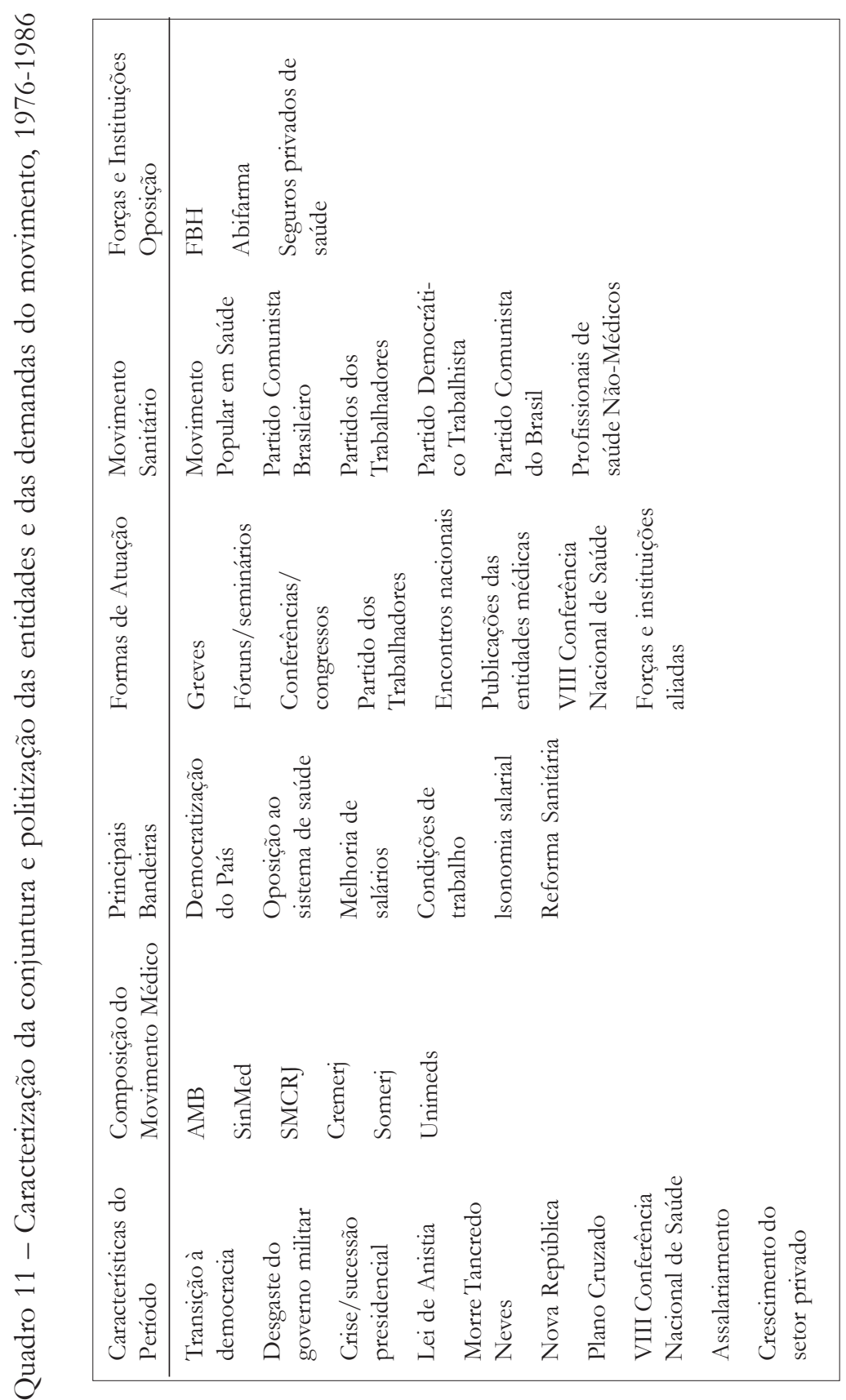




\section{A Ética Médica}

A Ética Médica foi gradualmente adquirindo relevância e se tornou objeto de discussão e de reflexão. Passou a constituir o eixo político principal na articulação da categoria no final da década de 80 .

Foi por intermédio do Conselho Regional de Medicina que a questão da Ética Médica entrou na agenda do Movimento Médico, estimulando a formação de comissões de ética nas unidades hospitalares e intensificando a discussão acerca do assunto, de modo a elaborar um novo código compatível com a realidade da prática médica no Brasil.

Essa linha de atuação foi encaminhada tanto nos fóruns de debate quanto nas reuniões das comissões de ética, que forneceram subsídios para a formulação de um projeto de código com a participação da categoria. Paralelamente, o Cremerj reunia-se periodicamente com os Conselhos de outros estados e discutia propostas para um novo código junto ao Conselho Federal de Medicina.

Ao término do ano de 1988 mais de cem comissões de ética haviam sido instaladas em hospitais municipais, estaduais e da rede do Inamps, bem como em hospitais da rede privada. Aproximadamente dois mil médicos do município do Rio de Janeiro e do interior do estado participaram ativamente dessas comissões, inúmeras vezes entrando em conflito com diretores de hospitais, empresários do setor e autoridades. ${ }^{42} \mathrm{O}$ Sindicato, pela colaboração que deu ao Conselho na tarefa, acabou também atuando na formação das comissões de ética nas unidades hospitalares.

Foi intensa a atividade desenvolvida pelo Cremerj na elaboração de um novo Código de Ética Médica, durante o período. As discussões em hospitais, entidades médicas, delegacias regionais e comissões de ética tiveram expressiva participação dos médicos. Demonstrava a preocupação em colocar as questões relativas aos problemas enfrentados no trabalho cotidiano, dentro da complexa e nova realidade da prática profissional, o qual interferiam fatores vários, além da relação médico-paciente. Enfatizaram-se aspectos tais como a relação dos médicos com as instituições de saúde, a desumanização do atendimento, a garantia de exame e a elaboração do prontuário para o paciente, assim como a definição de responsabilidades em caso de remoção.

O anteprojeto do Código de Ética, elaborado na Conferência Estadual de Ética Médica, acentuava aspectos relacionados às pesquisas em seres humanos,

$\overline{42}$ Segundo dados fornecidos pela diretoria do Cremerj. 
transplantes de órgãos e de tecidos e questões de direitos humanos, a serem respeitadas no exercício profissional. A proposta do Rio contou com a segunda maior bancada de delegados à Conferência Nacional de Ética Médica.

No evento, inédito na história da medicina do País, elaborou-se o novo Código de Ética Médica, que detalhou e aprofundou as normas éticas, ficando bem mais extenso que o anterior. Ao se considerar que os médicos são preponderantemente assalariados, inovou-se em conceitos como a extensão da responsabilidade pelo ato médico à unidade de saúde e a obrigatoriedade do médico em denunciar ao Conselho as más condições de trabalho.

Igualmente inovador foi o capítulo sobre direitos humanos, no qual a prática da tortura foi execrada, bem como proibido o envolvimento do médico, direta ou indiretamente, na execução da pena de morte, no caso de ela vir a existir. Tais questões entraram no projeto quando a participação de médicos na prática da tortura se tornou conhecida devido aos processos iniciados por organismos de direitos humanos e por familiares dos presos políticos, durante o regime militar. Outra diretriz inovadora foi a que se referiu à não-mercantilização da medicina.

Conforme as diretrizes da VIII Conferência Nacional de Saúde, o novo código adotou o conceito ampliado de saúde, entendendo não como ausência de doença, mas como resultante de adequadas condições de alimentação, habitação, saneamento, educação, renda, meio ambiente, emprego, lazer e garantia dos direitos sociais, a serem asseguradas pelo Estado etc.

O novo Código de Ética refletiu as principais aspirações do Movimento Social em Saúde. Foi o resultado de anos de debates e reflexões sobre as experiências da prática médica e da luta dos profissionais em saúde no novo contexto brasileiro, constituído a partir da década de 70 . Refletiu ainda a vitória das concepções 'trabalhistas' de medicina sobre o ideário liberal da prática médica. Em seus princípios fundamentais, ligou a atividade dos médicos às condições de saúde e aos padrões dos serviços médicos. Dessa forma, responsabilizou o médico pelo bom funcionamento do sistema de saúde.

O papel aglutinador que desempenhou a implantação de Comissões e a elaboração do Código de Ética Médica fez com que o Conselho Regional de Medicina se tornasse o principal órgão de expressão política da categoria, lugar anteriormente ocupado pelo Sindicato dos Médicos. No entanto, o estabelecimento da democracia no País impôs problemas e desafios que a categoria não conseguiu assimilar nem responder, nem mesmo através da elaboração de estratégias adequadas àquele novo momento político-econômico. 
A questão da Ética Médica não teve força suficiente para, como bandeira de luta política, se impor ao conjunto da categoria, já que se tratava de uma proposta de caráter marcadamente político na atuação dos médicos. Ainda que aprovada, e portanto, obrigatoriamente respeitada, expressou um descompasso entre o Movimento Médico, que não mudou sua proposta, e a categoria profissional, que defendia propostas de cunho corporativista.

O momento político relacionado ao estabelecimento de um regime democrático difere substancialmente do período de transição do autoritarismo para a democracia. As questões democráticas durante a transição relacionam-se à ampliação das liberdades políticas, fundamentalmente da liberdade de expressão e de organização da sociedade. Se às restrições políticas do regime autoritário somarmos as mudanças no sistema de saúde que conduziram a uma pauperização dos profissionais médicos, compreende-se que a junção da luta política com a luta por melhores condições salariais e de trabalho dos médicos, empreendida pelas lideranças médicas, tenha encontrado receptividade na categoria.

A estratégia seguida pelo Movimento Médico teve por alvo a queda do regime militar e, neste sentido, houve adequação entre o objetivo e a estratégia para alcançá-lo, centrada no inconformismo da categoria médica com as transformações no exercício da profissão.

A consolidação da democracia trouxe como questão principal, porém, a construção da institucionalidade democrática: novos padrões de relacionamento entre Estado e sociedade e mecanismos políticos que garantissem a discussão ordenada das reivindicações de diversos setores sociais, ou seja, as condições para impulsionar o processo de mudança.

Para se estabelecer, esse processo enfrentou, por um lado, a resistência às transformações por parte das elites políticas no Brasil, essencialmente a renúncia a benefícios conquistados há bastante tempo e aprofundados com o regime militar. Essa resistência evidenciou as dificuldades no Estado brasileiro. Por outro, o Movimento Médico deixou de ter atuação política unificada, como teve durante a oposição e resistência ao regime militar, para expressar as profundas diferenças na categoria médica. Os interesses e demandas dos médicos assalariados do setor público, daqueles inseridos nos seguros privados, dos proprietários de hospitais e dos conveniados diferiam e exigiam modalidades próprias de discussão.

Da perspectiva da sociedade, a representação plural de interesses, sem ter havido um processo de adequação de formação política das representações 
pela via institucional, levou 'todos a quererem tudo', de modo que as demandas reprimidas durante o regime autoritário e expressas simultaneamente produziram a tão conhecida situação de ingovernabilidade da democracia.

Ao tempo que, ao apelarem os médicos para greves como principal instrumento de pressão para obter melhores salários e condições de trabalho, enfrentaram a rejeição dos usuários, especialmente do setor público, e por extensão, a crítica da sociedade à categoria.

\section{Relação com o Estado e o Processo Constituinte}

Na década de 70 e na primeira metade dos anos 80 o Movimento Médico caracterizou-se por uma atuação relevante no setor saúde, no questionamento às políticas de saúde e na elaboração de uma proposta de reformulação do sistema que culminou com a Reforma Sanitária.

A partir da segunda metade da década de 80 houve um deslocamento da discussão política da Reforma Sanitária para o Sistema Unificado e Descentralizado de Saúde (Suds). A Reforma Sanitária era mais ampla que o Suds. Enquanto a primeira era uma proposta de cunho político-filosófico a respeito do setor da saúde, a segunda era um instrumento administrativo do Estado para encaminhá-la.

A implantação do Suds, em 1988, guiou-se pelos princípios da Reforma Sanitária, mas não conseguiu efetivá-los. Tratou-se de uma reforma administrativa do sistema de saúde na qual o Instituto Nacional da Previdência Social (Inamps) - principal órgão do sistema público de saúde - repassou suas unidades, segundo a localização, às secretarias de saúde de estados e municípios. A partir disso as unidades passaram a ser administradas regionalmente, tanto na gestão quanto no financiamento.

O Suds atravessou enormes dificuldades em razão de diversas causas, dentre as quais se destacaram o avanço das burocracias locais e a interferência de políticos clientelistas, no nível municipal; o emperramento dos repasses dos recursos para estados e municípios sem que se conseguisse detectar em que lugar estes desapareciam; e os entraves legais e operacionais no funcionamento dos Conselhos de Saúde que obstaculizaram a participação da população na gestão das unidades locais.

Logo no início da implementação da política de saúde observa-se um importante retrocesso na proposta da Reforma Sanitária, manifesto pela saída 
dos quadros ligados ao Movimento Sanitário dos cargos de direção do Inamps. Já em pleno processo de implantação, outro aspecto desse retrocesso se refere ao boicote, em 1999, do Governo Collor à Reforma Sanitária e às manifestações contrárias à mesma por parte do setor privado da saúde.

O Suds foi constantemente apontado pela Somerj e por outras entidades como a 'única saída' para a situação caótica do sistema público de saúde, mas as denúncias relacionadas às dificuldades na implementação da Reforma Sanitária, em sua totalidade, eram pouco enfáticas e muito gerais se comparadas às ações desenvolvidas pelo governo no emperramento do Suds.

Para seu efetivo sucesso, a Somerj defendia a criação de um Fundo Único de Saúde com recursos dos estados, municípios e Inamps, e de uma dotação orçamentária federal para a criação de Conselhos Estaduais e Municipais de Saúde e para a isonomia salarial para os médicos, a médio prazo.

Fica evidente, através dessas iniciativas, que as entidades mantiveram um discurso comprometido com as questões relacionadas à Reforma. No entanto, não houve uma contribuição de vigilância mais concreta da categoria para implementar um sistema único de saúde que controlasse a multiplicidade de inserções profissionais dos médicos e que exigisse destes a dedicação integral e o cumprimento da carga horária. Ou seja, é possível observar o distanciamento entre as proposições gerais da categoria e a transformação da prática médica dentro de uma orientação onde os interesses da corporação fossem compatibilizados com as mudanças no sistema de saúde.

Tal questão fica ainda mais clara ao se analisar o material reunido a respeito da atuação das entidades médicas na VIII Conferência Nacional de Saúde, onde se percebe que duas questões começaram a merecer destaque no âmbito da Reforma Sanitária. A primeira delas foi o que diz respeito à isonomia salarial para os médicos. Apesar de ter sido sempre considerada uma necessidade, a partir da formulação do Plano das Ações Integradas de Saúde, em 1983, a isonomia passou a ter importância superior aos próprios projetos que a circunscreviam, inclusive à Reforma Sanitária.

A segunda questão era bem mais polêmica, já que se tratava do emprego único, com salário único e tempo integral de trabalho. As lideranças médicas reconheceram haver grande resistência da categoria a essa proposta e assumiram que muitos deveriam ser conscientizados participantes do novo sistema. No entanto, estabeleceram algumas precondições: "os médicos aceitariam discutir emprego único com tempo integral no caso de adequadas condições de 
trabalho e se fossem estabelecidos mecanismos institucionais que impedissem, em qualquer hipótese, a redução ou achatamento desses salários". 43

É preciso ressaltar que essas precondições eram impossíveis de ser encontradas no fim da década de 80 .

Em relação à organização do trabalho médico, destacamos que no VI Encontro Nacional de Entidades Médicas, em 1987, definia-se o trabalho médico como uma "forma de compromisso social" onde deveria ser sempre "auscultado e respeitado o interesse da sociedade". Afirmava-se ainda que a "inserção do trabalho médico na produção social constitui um direito de todos os médicos, cuja garantia deve ser assegurada pelo Estado". ${ }^{44}$ Depreende-se disso que a categoria aparentemente assumiu que o compromisso social era inerente à profissão médica e que caberia ao Estado assegurar trabalho para todos os médicos.

Além disso, no Encontro, foi salientada a necessidade de preservar a relação médico-paciente na prestação dos serviços, procurando os médicos se desobrigarem de quaisquer tipos de controle sobre seu trabalho, como se pode observar na seguinte afirmação do presidente do SinMed: "as instituições que intermediam o trabalho médico não podem interferir com seu compromisso ético e social". Fica portanto evidente a preocupação da categoria em estabelecer parâmetros que limitassem a interferência do Estado sobre o trabalho médico, certamente no sentido de garantir a prática liberal, mesmo sob condições de assalariamento.

Cabe ressaltar, através da análise dessas questões, o papel prevalente que a categoria se atribuiu na formação das políticas de saúde. Havia na categoria médica uma posição ambígua observável também na atuação das entidades médicas.

Ainda que o Cremerj tivesse preservado um papel mais político e menos corporativo, a tônica do conjunto das instituições médicas foi bastante dúbia. As tentativas de manter o exercício liberal da medicina naqueles aspectos que interessavam aos médicos fez-se acompanhar da exigência de intervenção do Estado para favorecer questões que eram do interesse da categoria, tais como a garantia de emprego para todos os médicos, isonomia salarial, não obrigatoriedade de tempo integral, garantia de estabilidade e as 40 horas semanais apontadas pela Reforma Sanitária. Ou seja, ao mesmo tempo em que se

43 Declarações de Roberto Chabo, presidente do SinMed. Edição Médica, 67:7, 1987.

44 Edição Médica, 68:7, 1987. 
defendiam posturas liberais, exigia-se a intervenção do Estado em aspectos nos quais o liberalismo prejudicava o exercício da medicina.

Essa ambigüidade nos remete à discussão do tema autonomia médica, que configura um dos principais componentes da ideologia médica, à qual é ligada, e do exercício da medicina desde seu começo até os dias atuais, o que merecerá abordagem específica.

Retomando agora o papel das entidades médicas nas políticas nacionais de saúde, observamos que a discussão em torno da Constituinte foi defendida completamente pelo Cremerj. No acompanhamento dos trabalhos da Assembléia Nacional Constituinte a entidade teve uma de suas mais destacadas atuações em nível nacional.

Com a proximidade da votação da Seção da Saúde pela Plenária da Constituinte, o Cremerj se transformou no centro mobilizador do movimento nacional em defesa das diretrizes da VIII Conferência Nacional de Saúde e lançou boletins, cartazes e um manifesto em defesa da proposta da Reforma Sanitária, assinado por governadores, secretários de saúde, pelo prefeito do Rio de Janeiro e por centenas de entidades do setor.

Salientamos que posteriormente à aprovação da Constituição Nacional e dentro dos esforços para se levar a questão da saúde à sociedade, a Plenária Estadual de Saúde, convocada pelo Cremerj em outubro de 1988, reuniu cerca de 60 entidades da sociedade civil para discutir a Constituinte Estadual.

Volta assim a desempenhar o Conselho um importante papel de mobilização política ao liderar as lutas pela reforma do sistema de saúde. Todavia, nosso ponto de vista é que, da mesma forma que na discussão sobre a Ética Médica, isso acontece sem que se observe uma importante mobilização da categoria na definição da Constituição Estadual.

No entanto, apesar da ausência de uma considerável adesão da categoria à qual interessava muito pouco os princípios que conduziram à Reforma Sanitária -, a proposta encaminhada pelas entidades à Constituinte foi essencialmente a mesma da Subcomissão de Saúde da Câmara, na qual tinham assento o Movimento Sanitário e as organizações do Movimento Social em Saúde.

Por fim, já em 1989, durante a Plenária Estadual de Saúde, uma proposta de anteprojeto referente ao setor, para a Constituinte Estadual, foi elaborada pela Somerj e outras entidades de saúde, sindicatos e associações de moradores.

Em linhas gerais, o anteprojeto defendia a criação do Sistema Estadual de Saúde com vinculação ao Sistema Único de Saúde, onde se propunha: 
- a municipalização dos recursos;

- o financiamento da seguridade social através do orçamento do estado, da União, dos municípios e de outras fontes;

- a participação de entidades representativas nos Conselhos Estaduais e Municipais de Saúde, de usuários e de profissionais de saúde nas decisões sobre o sistema.

De maneira geral, o papel do Movimento Médico no processo constituinte estadual foi bastante progressista, sem que tenham existido aspectos polêmicos de envergadura no âmbito interno das entidades médicas. O Cremerj tornou-se o porta-voz na articulação do Movimento Social em Saúde, como um todo, no estado do Rio de Janeiro.

De qualquer modo, para não gerar confusões, devemos enfatizar que mesmo que o projeto tenha sido aprovado pela Constituinte, toda essa atividade política do Conselho teve repercussão relativa no conjunto da categoria médica.

\section{As Greves e o Corporativismo Médico}

No período pós-85 percebe-se um crescimento desmedido de reivindicações econômico-corporativas da categoria médica em relação a períodos anteriores. De fato, registrou-se uma mudança na categoria ao término da década: da atuação política de oposição ao regime militar - que acompanhou as greves realizadas na década de 70 - ao início dos anos 80 aumentaram as greves que reivindicavam exclusivamente aumentos de salários e melhores condições de trabalho.

A expectativa inicial com a Nova República não demorou a se desfazer. Com isso, as reivindicações por melhores salários, condições de trabalho, redução de carga horária, entre outras, começaram a ocupar um lugar principal no âmago da categoria. A greve dos funcionários do Ministério de Saúde no estado do Rio de Janeiro, em 1985, foi pautada pela reivindicação de 80\% de reposição salarial, efetivação do pessoal das campanhas nacionais (tuberculose, câncer e saúde mental) e a redução da carga horária de 40 horas para 30 horas semanais.

Em 1986 e 1987 a greve dos médicos previdenciários exigiu aumento de salários e a elaboração de um Plano de Cargos e Salários. Nesse mesmo período, no interior do Rio de Janeiro, assim como em outros estados do País, sucederam-se movimentos grevistas também. 
Dentre as lutas salariais travadas pela categoria, destacou-se a greve de 162 dias dos funcionários municipais, que gerou crise sem precedentes na assistência à saúde na cidade do Rio de Janeiro. Inicialmente decidida durante o VII Encontro Nacional de Entidades Médicas, o Dia Nacional de Luta (22/09/1988) teve a participação de todos os previdenciários e profissionais de saúde federais, estaduais e municipais.

As reivindicações dos médicos foram a isonomia salarial com o Inamps; implantação imediata da tabela de honorários médicos da AMB para hospitais conveniados e para o Inamps; elaboração de Plano de Cargos, Carreiras e Salários unificado nacionalmente; mudança da legislação do trabalho médico, com definição de piso salarial.

Dentre todos os participantes, continuaram paralisados apenas os médicos previdenciários e os profissionais municipais, tendo a greve terminado em março de 1989 em virtude de a Prefeitura ter cancelado o pagamento de todo o funcionalismo municipal.

O Sindicato destacou-se na condução das greves, o que ajudou a redefinir seu papel no setor, com ênfase no exercício da representação dos interesses trabalhistas da categoria mais do que na representação política, que caracterizara a atuação do SinMed na década anterior.

Durante essa greve, o Cremerj foi a única entidade que se posicionou nitidamente ao lado da população e contra o movimento. Garantiu um mínimo de assistência e liderou a luta para exigir providências das autoridades.

As greves dos médicos, sem solução de continuidade, foram criando uma situação de desassistência à população que se arrastou durante meses. Como não existia nenhuma forma de planejamento para o funcionamento dos serviços de atendimento, mesmo de maneira emergencial ou provisória, a população atribuía à categoria médica a culpa pelo abandono em que se encontrava o setor público da saúde.

As entidades médicas, ainda que defendessem a paralisação, apoiaram também as demandas do Movimento Popular em Saúde e da população em geral, atribuindo os problemas de atendimento ao governo. Por fim, a categoria levou a greve até o esgotamento, acabando por perder efetividade essa forma de resistência à situação de deterioração salarial e das condições de trabalho dos médicos empregados no setor público da saúde.

O posicionamento de responsabilidade civil, assumido pelo Cremerj na greve, possibilitou nova reunificação entre as entidades médicas e as entidades 
do Movimento Popular em Saúde, o que ficou evidenciado na participação conjunta na Plenária Estadual de Saúde e na mobilização popular denominada Marcha pela Saúde. Desta participou um grande número de entidades da sociedade, além da Somerj, Confederação Nacional dos Médicos, Federação Nacional dos Médicos e o SinMed do Rio de Janeiro e de Niterói.

Independentemente de as reivindicações serem ou não justas, é necessário assinalar que essa greve provocou a maior crise de atendimento do setor público antes vista. Foram diversos meses em que filas, mortes por falta de atendimento e a insensibilidade com o sofrimento humano foram a tônica da atuação da categoria médica, noticiada incansavelmente pela imprensa. Como desdobramento da situação, ocorreu um notável desprestígio dos médicos, preocupados muito mais com a defesa de seus interesses do que com as conseqüências advindas das sucessivas paralisações.

Outro fato que bem demonstra o conflito existente entre a categoria e a população, no período, é a determinação tomada pelo Instituto Nacional de Previdência e Assistência Social (INPS) de transferir médicos de diferentes unidades hospitalares de bairros residenciais de classe média e alta para o Hospital da Posse em Nova Iguaçu, uma das regiões mais pobres da periferia do Rio de Janeiro.

Isso porque os médicos concursados que deveriam ser encaminhados para exercer sua atividade no Hospital da Posse ficaram alocados em hospitais melhor situados do município, em razão de influências políticas. Acabou, assim, havendo reação à decisão por parte da categoria e das entidades médicas, principalmente do SinMed, que protegeu os médicos que se recusavam à transferência. As entidades médicas conseguiram influir na decisão do Ministério da Previdência, que acabou concordando em chamar médicos aprovados em outros concursos.

Nesse período também cresceu, aparentemente, a preocupação da categoria com a desconfiança da população em relação aos médicos, enfatizando-se a necessidade de recuperar a credibilidade perdida. Para a classe, essa desconfiança se devia à culpa sempre creditada aos médicos por erros que na realidade seriam causados pelas deficiências do sistema de saúde. Poucas vezes os médicos aceitaram a responsabilidade pela situação. ${ }^{45}$

45 Como exemplo há um editorial do periódico Edição Médica em que são feitas críticas à situação da medicina no estado do Rio. Segundo o editorial, as lutas do Movimento Médico teriam conquistado importantes avanços salariais, mas com poucos reflexos na maior parte do atendimento assistencial, o que tirava sua respeitabilidade até para "reivindicar melhor salários e condições de trabalho". Acrescenta que: "é crescente o número daqueles que compreendem que sem o resgate da respeitabilidade do médico perante a sociedade em geral, qualquer movimento médico cairá no vazio" (Edição Médica, 70, 1988). 
Acreditamos que isso tenha acontecido porque havia uma compreensão deturpada que permeava a categoria, sobre a diferença entre condições de trabalho e exercício da medicina. Ou seja, na medida em que não se distinguia o fato de ser assalariado - questão que tem a ver com a inserção laboral -, do exercício da prática médica independente da condição de assalariamento e inerente ao profissional médico - lidar com o ser humano doente -, também não se conseguia isolar as responsabilidades do Estado quanto ao atendimento hospitalar e as do médico.

\section{Os Convênios com o Setor Privado}

Importantes transformações ocorreram no mercado de trabalho médico a partir da segunda metade da década de 80 . A visível deterioração do setor público da saúde em virtude da falta de recursos para a manutenção das instalações e para o pagamento dos profissionais ficou evidenciada na redução de leitos hospitalares: de 4,28 leitos/1.000 habitantes em 1980 caiu para 3,72 em 1989, tendo, no período, havido a expansão de leitos no setor privado $(+4,68 \%)$ e decréscimo no setor público (- 2,61 \%) (Buss, 1994).

De fato, o atendimento no setor público implicou um incremento dos riscos ao se submeter o paciente a intervenções médicas. Essa situação foi muito bem aproveitada pelos seguros privados, que cresceram significativamente no período. Ou seja, quem tinha disponibilidade adquiria seguro privado de saúde, ficando o atendimento público restrito à parcela da população que não tinha reservas para gastos em saúde, fechando ainda mais o círculo da pobreza.

Com o crescimento dos convênios privados de assistência à saúde - os seguros de saúde - e a concomitante decadência da assistência pública, o trabalho por credenciamento ganhou importância singular para a categoria, passando a ser até mesmo uma fonte exclusiva de renda de grande parte dela.

O credenciamento médico é uma modalidade específica de contrato entre os médicos e os seguros privados, hospitais ou outros serviços de saúde. A parte empregadora credencia (habilita) médicos para o atendimento sem se comprometer a lhes encaminhar pacientes e nem efetuar o pagamento de salários, mas inclui o médico na lista dos que integram a empresa. O paciente faz sua escolha nessa listagem e a empresa fornece, para o pagamento da consulta, tíquetes posteriormente trocados por valores pelo médico, segundo tabela de honorários previamente estabelecida pela empresa. Isso explica a atenção dada 
pelas entidades à questão e também a preocupação em estabelecer critérios que garantissem direitos a essa parcela dos médicos, tendo em vista principalmente a não-exploração do trabalho médico.

As entidades reconheceram, durante o VI Encontro Nacional de Entidades Médicas, realizado em 1987, que o credenciamento era utilizado muitas vezes como forma de subemprego, sendo aplicado de diferentes maneiras tanto no setor privado quanto no próprio setor público. Assim, procuraram estabelecer critérios que melhorassem essa relação de trabalho para a categoria, tendo a principal proposta sido a de que o credenciamento deveria ser universal. Além disso, determinaram que fosse feito exclusivamente nos consultórios particulares e de nenhuma forma no sistema público, onde o ingresso deveria ser apenas por concurso.

O credenciamento universal, nesse sentido, viria como forma de prestação de serviço relativamente autônoma, já que os médicos não seriam obrigados a se filiar aos convênios. Poderiam atender pacientes de diferentes convênios, os quais, sem dúvida, os tornavam assalariados e indiretamente os impediam de 'escolher' pacientes, além de não lhes exigir nenhum tipo de controle sobre sua formação.

Esse posicionamento representou uma visão estritamente liberal sobre a forma como deveria ser exercida a prática médica. Ademais, em nosso ponto de vista, é uma situação contraditória com o reconhecimento, pela própria categoria, do baixo nível de formação acadêmica, que, não exigindo concurso, requereria um outro tipo de controle sobre o exercício do profissional.

Manteve-se, nessas discussões, a proposta de que o pagamento aos credenciados tivesse por base sempre a tabela de honorários médicos da AMB e fosse desvinculado das contas dos hospitais. Como era de se esperar, boa parte das empresas de medicina de grupo ignorou a tabela, o que resultou em greves dos médicos conveniados. O Sindicato procurou então conscientizar os médicos da rede particular sobre seus direitos, promovendo encontros com essa parte da categoria. Essa luta ampliou consideravelmente o alcance do SinMed.

A preocupação das entidades com essa vasta parcela da categoria inserida no setor privado demonstra, por um lado, a diferença com períodos anteriores, em que não eram consideradas suas reivindicações. Houve mudanças na concepção que privilegiava os assalariados do setor público.

Cabe ressaltar, no entanto, as mudanças ocorridas na prática liberal, onde o mercado passou a ser cada vez mais dependente dos convênios com empresas. 
Em verdade, essa mudança seria apenas, de acordo com nossa opinião, parte do processo de aniquilamento da prática liberal, mascarado pela utilização dos convênios, indicando a forma latente com a qual se apresentava a ideologia liberal entre os profissionais médicos.

\section{De Volta à Prática Liberal...}

O Movimento Médico pós-83 mostrou como as entidades médicas voltaram a privilegiar seus problemas corporativos, solidificando uma nova ideologia a partir da proposta de engajamento num projeto reformador da saúde.

Um desses indicativos foi o visível descenso do Sindicato dos Médicos enquanto entidade que se fortaleceu com o Reme e dirigiu importantes lutas da categoria ao voltar-se para problemas especificamente corporativos.

A prioridade dada pelo Reme ao processo de democratização do País ao projeto reformador na saúde e ao assalariamento médico, juntamente com um certo abandono dos problemas específicos urgentes para a categoria médica, pode ter significado a abertura de espaço para o aparecimento de uma nova corrente política no 'coração' do Movimento Médico, a corrente neoliberal que privilegiava, ao contrário, as questões específicas da categoria (Campos, 1986).

Esse fenômeno poderia ser explicado pelo fato de não ter havido preocupação mais específica do Reme com questões que faziam parte do dia-a-dia da prática médica e que mobilizavam a categoria, principalmente a salarial. Realmente essa questão estava embutida nas demandas políticas mais amplas de democratização do País porque se entendia que esta era a via para mudar a situação profissional dos médicos.

Entretanto, a ideologia liberal hoje não é mais a ideologia tradicional que se opõe à presença do Estado na prestação da assistência à saúde, que nega o assalariamento como forma antiética do exercício profissional e que usa essa ética como forma de relacionamento primordial tanto entre os próprios médicos quanto com a sociedade em geral.

Fruto das transformações ocorridas no setor saúde, principalmente nas décadas de 60 e 70, essa ideologia passou a conviver, cada vez mais, de forma independente de sua vontade, com a heterogeneidade na inserção dos profissionais médicos no mercado de trabalho.

A enorme inserção dos médicos nos serviços de saúde, fossem públicos ou privados, determinou que os profissionais médicos não mais respondessem 
a uma conduta decidida entre eles próprios, mas que esta fosse definitivamente intermediada por outra - a da organização hospitalar que o empregava.

Tornava-se necessário, portanto, reavaliar essa conduta no sentido de responder à heterogeneidade e não perder o que, em nossa opinião, é a base da unidade da profissão, ou seja, a legitimidade imputada pela sociedade ao trabalho do médico no enfrentamento da enfermidade, importância essa que lhe dá prestígio e lugar diferenciado na hierarquia social.

As novas formas de inserção profissional contribuíram para o surgimento de três tipos diversos de ideologia, na década de 70. Segundo Donangelo (1984), seriam elas a ideologia liberal, a empresarial e a estatizante, que enfrentavam conflitos, em última instância resolvidos no âmbito da ética médica.

No entanto, o acirramento das contradições entre os diferentes interesses desnudava uma vez mais a fragilidade do pacto firmado sobre a ética - princípio da medicina que guia o exercício da prática médica. As diferenças ficaram evidentes sobretudo a partir da reorganização do Movimento Médico, na segunda metade da década de 70, com a entrada do Reme na cena política.

Ao defender a prestação dos serviços de saúde pelo Estado e condenar a sua mercantilização, o Reme fez também uma nítida opção pela transformação da assistência à saúde em benefício da maioria da população e assumiu abertamente a defesa dos assalariados médicos. Representava, portanto, uma diferenciação explícita tanto em relação aos liberais tradicionais quanto aos empresários médicos. A proposta empreendida pelo Reme tomou corpo com a conquista de inúmeras entidades brasileiras, no período de 1979 a 1983.

A resposta a esse crescimento não tardou a ser formulada. Ainda em 1980 começou a se organizar uma terceira corrente política que visava, em nossa opinião, reorganizar a unidade cindida da categoria médica, então baseada na representação quase exclusiva dos médicos assalariados. A divisão da categoria punha em risco a posição da profissão médica, ameaçando-a de vir a ser uma profissão 'como outra qualquer'.

Essa nova corrente, chamada de neoliberal por Campos (1986), adotou o que o autor chama de "sincretismo político", no sentido de aliar interesses tanto dos liberais quanto do Reme. Propunha-se a defender tanto os médicos liberais quanto os assalariados e assumia, por um lado, que a categoria tinha se afastado dos centros de poder e que necessitava se unir à população para exigir do governo uma política de saúde em benefício de todos. Por outro, centrava o foco de suas acusações no governo e no Inamps, cujo planos de saúde visavam, 
para os neoliberais, apenas administrar escassos recursos e adequar a saúde às disponibilidades financeiras. Para atingir seu objetivo, não titubeava em se aliar aos hospitais privados contratados pela Previdência Social e lhes propor uma aliança com os próprios médicos credenciados.

Dessa forma, os neoliberais visavam a 'unidade' dos médicos e realmente se entendiam enquanto representantes de toda a categoria, ao procurar responder com as propostas de atuação aos anseios dos profissionais nas diferentes formas de inserção no mercado.

No entanto, como afirma Campos, privilegiavam efetivamente a autonomia do trabalho médico. Ainda segundo o autor (1986), os neoliberais propunham uma terceira via que combinasse propriedade privada, exercício autônomo e intervenção do Estado, baseada, principalmente, na assistência previdenciária - produtora direta de serviços e financiadora, via credenciamento, de médicos particulares - e no cooperativismo médico. Criticavam, contudo, a lucratividade desmedida no setor, procurando com isso uma via que conciliasse a prática liberal às necessidades de atendimento da população necessitada.

Apesar de essa nova corrente ter surgido em São Paulo, em 1980, e contar com apoio principalmente nesse estado e no Rio Grande do Sul parece também ter influenciado a mudança de qualidade no movimento como um todo. No Rio de Janeiro teve influência expressiva, não obstante o Reme ser hegemônico. Essa mudança de curso se iniciou com as eleições realizadas na AMB, em que o Reme perdeu para a chapa denominada Nova AMB, presidida por Nelson Proença e identificada com a nova corrente.

Em verdade, o que esta 'nova proposta' no âmago da corporação assinalava era a retomada dos valores tradicionais da profissão médica, adequandoos às circunstâncias políticas que atravessavam o setor da saúde e os profissionais médicos nos anos 80 .

Neste sentido, não se tratava exatamente de uma proposta política de cunho neoliberal, tal como era entendida pelas correntes e escolas econômicas do neoliberalismo, uma vez que carecia de definição alternativa à Reforma Sanitária para a organização do setor, além de não assumir a sua defesa. No entanto, colaborou, em grande medida, para a retirada da adesão à Reforma empreendida pela corporação médica em épocas anteriores.

A proposta dos neoliberais tomou impulso e, certamente, onde não conquistou diretamente as entidades, influenciou suas diretrizes. $\mathrm{O}$ ingresso dos 
neoliberais na AMB em 1983, superando o então hegemônico Reme, resultou no declínio deste último.

Não estamos afirmando que os neoliberais tenham sido os responsáveis diretos por essa queda. As mudanças conjunturais na cena política nacional e de saúde, juntamente com as transformações operadas no mercado de trabalho médico, com o crescimento dos convênios e seguros privados de saúde e a deterioração do setor público, se refletiram numa desmobilização política do Movimento Médico.

Desse modo, o Reme não conseguiu contrapor-se à proposta neoliberal no que de mais importante ela oferecia à categoria, ou seja, a recuperação do ideário médico: por um lado, a possibilidade de manutenção do exercício liberal como principal objetivo dos médicos, mesmo que concomitante a outras formas de inserção como o assalariamento, e, por outro, a autonomia do trabalho médico, na medida em que a possibilidade de reversão da doença e promoção da saúde permanecia, em última instância, sob poder do médico. Mesmo que o Reme não se opusesse diretamente à prática liberal da medicina, via o assalariamento médico como definitivo.

O reordenamento da ideologia médica no que chamaríamos de 'nova ideologia liberal' era, no entanto, mais extenso do que o que era explicitado na proposta dos neoliberais. Extenso no sentido de que revestia antigos valores com nova roupagem e buscava o apoio do conjunto da categoria, independente de sua inserção no mercado de trabalho.

A preocupação com a autonomia não se restringia exclusivamente a uma questão ética, para essa determinada corrente, mas implicava também a garantia de que os médicos não estivessem condenados ao assalariamento, podendo procurar outras formas de múltipla inserção no mercado.

Essas formas, na realidade, encobriam o assalariamento, como já vimos, e foram colocadas em prática pelos médicos nos últimos anos. Ou seja, a autonomia não significaria somente a possibilidade de realização profissional dos médicos em um plano simbólico da prática médica, mas também uma maneira de manutenção da renda ou a possibilidade de incrementá-la.

Contudo, a manutenção do ideário de 'posse' sobre a doença ratificava, ao revés, a manutenção de uma posição predominante nas instituições de saúde junto a um lugar privilegiado na hierarquia social, servindo como aval ao exercício autônomo tanto para manter os ingressos quanto para se desvencilhar de possíveis controles. 
Por fim, acredito ter a ideologia liberal penetrado no Movimento Médico não só pelas questões aqui apontadas, mas por ter sido também constitutiva dos médicos enquanto ideário da corporação.

O nascimento da prática médica está associado ao conhecimento especializado exercido no começo da carreira de maneira individual, independente das instituições médicas, que só apresentam caráter de congregação e de formador onde a autoridade médica é o próprio médico.

Assim, desde a formalização do ensino médico universitário classifica-se o profissional médico egresso das faculdades de medicina como profissional liberal. Embora tal denominação seja compartilhada com outras profissões de saber altamente especializado, no caso da medicina o exercício liberal norteia a atividade médica como referência principal.

Ainda que cruciais transformações tenham se produzido no transcorrer de aproximadamente um século no exercício da prática médica e ainda hoje nos deparemos com um 'modelo médico hegemônico' - baseado no trabalho assalariado, sob formas mais ou menos sofisticadas de exploração capitalista de produção e consumo de serviços de saúde -, o imaginário individual e social da categoria remete ao ideário médico do nascimento da medicina. Porém, o ideário médico se recria cotidianamente na relação médico-paciente, com o caráter individual e o intransferível eixo do exercício da prática médica.

Segundo Schraiber (1993:73), a autonomia médica tem razão de ser, na medida em que tanto o diagnóstico da patologia como o tratamento residem no julgamento do médico, na capacidade deste em desvelar a doença. ${ }^{46}$

Independentemente da adequação ou não dessa ideologia ao exercício da prática médica concreta, atualmente ela continua vigente na maneira como o próprio médico enxerga a sua prática profissional, atualizando-a em cada ato de intervenção médica, ainda que apenas no plano simbólico.

Assim, o ideário liberal reaflora sob traduções atualizadas que compatibilizam o imaginário social do médico com as circunstâncias concretas que perpassam pelo exercício da prática médica. Isso, precisamente no momento em que a categoria sente-se ameaçada de perder aquilo que tinha perdido na década de

\footnotetext{
46 Qualifica-se, então, também por essa via, a prática médica como prática fundada na competência pessoal do médico para desenvolver tal senso de particularização e exercitar sua subjetividade, estabelecendo inclusive as próprias regras de decisão e os limites de sua intervenção, ou de autoregulação. Para tal exercício, carregado de tantos e tão complexos requerimentos, não poderia ser outra a forma de desempenho, por necessidade de adequação do médico a seu ato de prática, que não aquela realizada por meio de sua inserção autônoma, quando então disporá o médico de amplas condições de adquirir e exercer sua experiência clínica individual.
} 
70 com o trabalho assalariado médico, mas que persiste no imaginário médico: o lugar privilegiado que este ocupava na sociedade.

Para finalizar, o quadro a seguir ilustra a atuação das entidades médicas no final dos anos 80, evidenciando uma notória despolitização das reivindicações médicas.

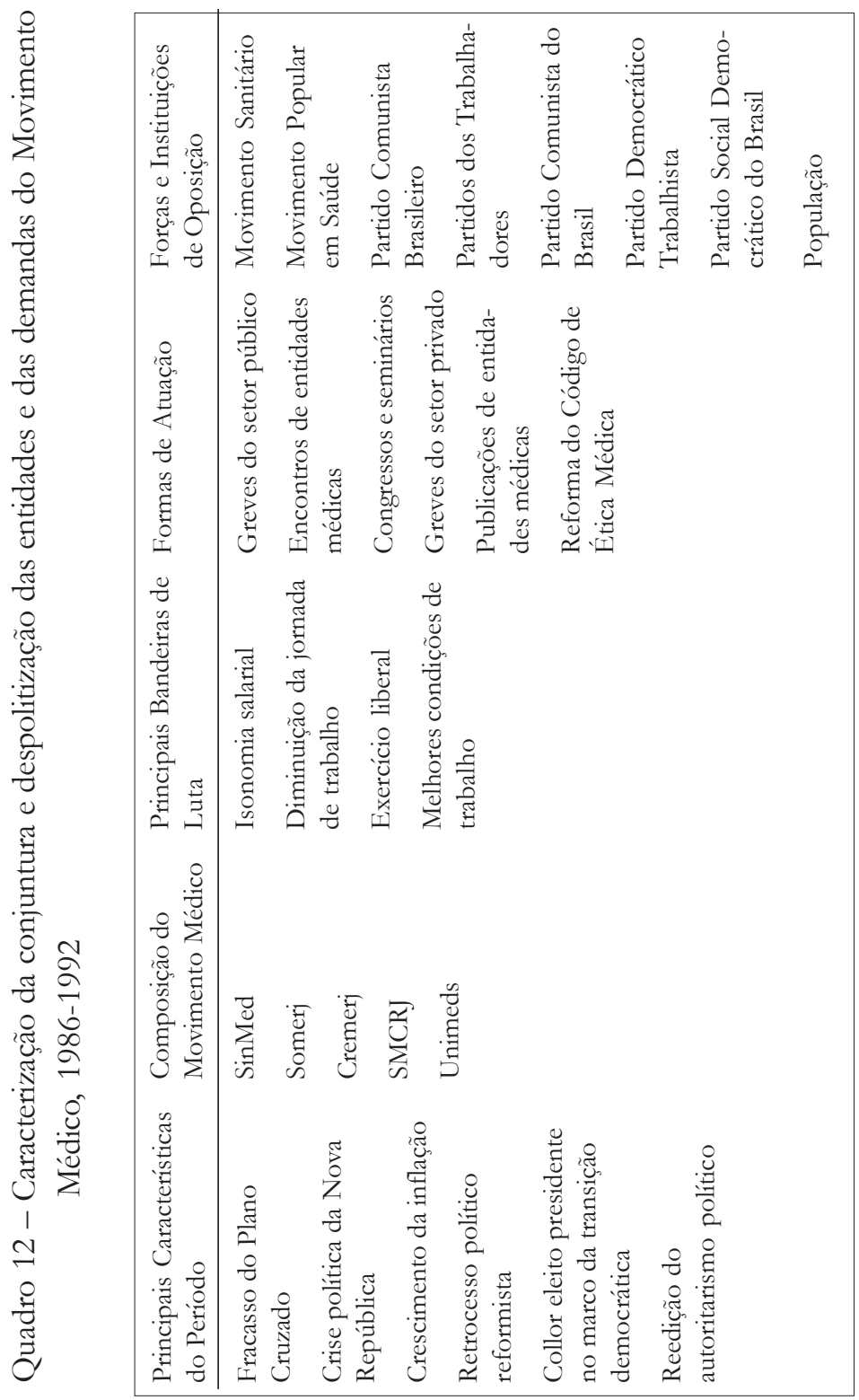


A primeira questão a salientar no estudo da atuação histórica das entidades médicas é a que diz respeito à denominação Movimento Médico. Tendo em vista que nosso interesse está focalizado nas políticas de saúde, especificamente no processo de formulação e implementação da Reforma Sanitária, constatamos o papel singular que as entidades médicas têm desenvolvido em relação às mesmas.

Assim como o Movimento Popular em Saúde, o Movimento Médico tem uma atribuição política decisiva no setor saúde. Ainda que sejam dois tipos de movimentos diferenciados quanto às bases sociais, formas de inserções na política e interesses - enquanto o primeiro reivindica serviços de saúde, o segundo se relaciona com a reprodução da força de trabalho -, ambos configuram o Movimento Social em Saúde.

A trajetória mostra como a política de saúde tornou-se alvo e objetivo da atuação das entidades médicas, mediatizada por reivindicações econômicocorporativas que se relacionam ao papel, indiscutivelmente diferenciado, dos médicos no sistema de saúde.

Embora em sua maioria sejam assalariados do setor público/privado da saúde, havendo alternância com outras formas de inserção no mercado, compõem ao mesmo tempo uma corporação que mantém regras de pertencimento e solidariedade profissional fortemente orgânicas. Trata-se, no entanto, de uma corporação bastante peculiar que tem exercido, ao longo das décadas de 70 e 80, diferentes modalidades de atuação política e de representação de interesses, via de regra referenciadas ao exercício da prática médica e à maneira pela qual determinado contexto político, social e econômico a afeta.

Enquanto o período da transição à democracia, no final dos anos 70, foi marcado pela oposição política ao regime autoritário, através de uma modalidade eminentemente plural da representação dos interesses da corporação médica, a década de 80 apresenta traços singulares da atuação política da categoria.

No período de construção da institucionalidade democrática houve uma fragmentação do movimento, na medida em que as diferenças na inserção profissional dos médicos no mercado de trabalho se aprofundaram, em razão do crescimento dos seguro privados de saúde, e a crise do setor público se agravou, além de a revitalização do ideário liberal ter ganho corpo para categoria.

Dessa maneira, a diversidade dos interesses médicos passa a ser expressa segundo a inserção dos médicos no mercado de trabalho, diferentemente do período anterior, no qual as entidades médicas e principalmente o SinMed representavam a categoria enquanto assalariados. 
Podemos observar, em conseqüência disso, a ausência de atuação política unívoca da corporação, concomitante ao crescimento da modalidade corporativa não-institucionalizada de representação de interesses das entidades médicas. Além disso, também nota-se que a relação entre a inserção profissional e as modalidades de representação de interesses no cerne da categoria reflete, no caso dos assalariados e dos profissionais liberais, uma mudança de representação plural para corporativa, enquanto as outras modalidades de inserção profissional, à medida que passam a se constituir oposição política, adquirem uma forma de representação plural de interesses.

O tratamento das questões referentes à ética médica, às políticas de saúde, às greves médicas, às transformações no mercado de trabalho e à ideologia neoliberal, consideradas do ponto de vista da trajetória histórica do Movimento Médico na construção da democracia, evidenciam as mudanças operadas na atuação das entidades médicas assim como na categoria como um todo.

Tais mudanças propiciaram cisão nas entidades médicas, tendo o Cremerj assumido um papel predominantemente político em relação ao processo do setor saúde, enquanto o SinMed passou a atuar exclusivamente como órgão sindical, liderando as greves econômico-corporativas da categoria e abandonando o rol político desempenhado durante a transição à democracia.

Outrossim, em relação à categoria, percebe-se tanto transformações na inserção profissional dos médicos no mercado de trabalho quanto uma forte penetração da ideologia neoliberal e um distanciamento da mobilização política da década de 70 .

Para finalizar essa discussão, caberia incorporar algumas reflexões teóricas sobre os movimentos sociais. Considerar a atuação desses atores sociais em termos de movimento social, com relação às políticas de saúde no processo de transição e construção da democracia, coloca-nos ante a necessidade de distinguir melhor os conceitos de ator social, de sujeito político e de indivíduo.

Entende-se por atores sociais as categorias sociais com organização própria e com expressão política. Neste sentido, atores sociais podem ou não ser sujeitos políticos. Constituem-se sujeitos quando adquirem uma identidade política construída com o desenvolvimento de uma prática política e na interrelação com outras forças políticas.

Da maneira como têm sido entendidos no Brasil, os movimentos sociais, mais referenciados aos movimentos populares das periferias dos grandes cen- 
tros industriais, se estabelecem em sujeitos políticos na relação com o Estado, na medida em que reivindicam saúde, moradia, educação, melhores condições de vida ante o Estado e por este são interpelados tanto pela presença quanto pela omissão na satisfação das necessidades da população. É precisamente na prática política que os movimentos passam a configurar uma identidade e a se tornarem sujeitos políticos. Não se poderia dizer que esses movimentos são atores sociais, já que sua base social é heterogênea e carece de organização e de expressão política duradoura e institucionalizada.

Considerando-se o Movimento Médico, podemos afirmar que ele é um ator social, na medida em que é uma categoria social com organização e expressão política. Conforme já mencionado, os atores podem ou não ser sujeitos políticos. Isso tem acontecido com o Movimento Médico em alguns momentos da história das políticas de saúde. Como atores sociais, se guia pelo pertencimento à corporação, mas como sujeito político sua atuação não é dada, pois se conforma no exercício da política.

Assim, na década de 70 os médicos fizeram um movimento que teve atuação política contra-hegemônica em relação à política de saúde dominante, o que se explica pela própria conformação do setor baseada na privatização, apoiada em complexos hospitalares, no trabalho assalariado, na especialização médica e na maciça incorporação de tecnologia.

Todas essas mudanças no exercício da profissão afetaram profundamente a autonomia do trabalho médico, levando a categoria e suas entidades a se mobilizar politicamente na oposição ao regime militar. A situação foi alterada por ininterruptas mudanças e com elas também a atuação tanto dos médicos como de suas entidades.

Feita a distinção entre atores sociais e sujeitos políticos, cabe a referência aos indivíduos. Estes se tornam sujeitos pelo reconhecimento da alteridade, tal como assinalamos no primeiro capítulo, e até poderiam, enquanto sujeitos políticos individuais, exercer a representação de grupos ou classes sociais.

Por vezes, o surgimento de um indivíduo - compreendido enquanto sujeito político único, com uma proposta política decisiva e em um lugar político decisório - pode ser o catalisador de um profundo processo de mudanças sociais, mas pode também não ser suficiente se não houver na sociedade sujeitos políticos que façam com que as mudanças ocorram.

Em certo sentido é necessário haver um resgate de indivíduos para a política, porque as sociedades são compostas por cidadãos com necessidades, anseios, 
desejos, intenções, gostos etc. Esse resgate da individualidade significa recuperar, no âmbito da sociologia e da política, a categoria de indivíduo, e principalmente recuperar o papel dos indivíduos nas atuais democracias. Não no sentido do individualismo possessivo e liberal, como afirmava MacPherson (1979), mas no sentido do homem, do valor essencial à humanidade. 
Parte III 


\section{Processo de Implementação da Reforma Sanitária}

Retoma este capítulo, como questão central, as políticas de saúde no processo de construção da democracia, mas em plano de análise diverso do adotado na primeira parte do livro. A discussão então empreendida possibilitou delimitar teoricamente o campo da democracia e, dentro deste, a capacidade de os sistemas políticos democráticos assimilarem processos de reformas políticas. Assim, foi posta no centro da atenção a Reforma Sanitária brasileira.

Da ênfase teórica dada ao tratamento da mesma, passamos agora a nos ocupar de sua dinâmica, com aqueles 'aspectos obscuros' que se evidenciam nos percalços do processo da implementação das políticas de saúde, procurando demonstrar que, para a efetivação da Reforma Sanitária, seriam necessários a continuidade e o aprofundamento do processo democrático. Regimes de exclusão social e de cunho autoritário dificilmente poderiam assimilar um processo de reformas dessa natureza.

Neste sentido, a incorporação de direitos sociais levou à incorporação de reformas estruturais no âmbito da economia e do Estado nas modernas democracias políticas. Sob esse ponto de vista, poderíamos afirmar que tem havido uma continuada luta entre o governo e as forças políticas e sociais, que entendem a Reforma Sanitária como o possível caminho para a democratização da saúde e seu usufruto pelo conjunto da sociedade, especialmente pelas camadas mais pobres e necessitadas da população.

Procuraremos inicialmente delimitar até onde se avançou no estabelecimento dos procedimentos legais previstos constitucionalmente para o setor saúde e qual o estado da arte até o final de 1993.

O avanço na implementação do novo sistema de saúde tem sido difícil a partir da regulamentação do arcabouço jurídico-institucional da Reforma Sanitária, estabelecido na Constituição Nacional em 1988, até os dias atuais. 
O último ano e meio do Governo Sarney caracterizou-se por grande deterioração política e por notável retrocesso na área da saúde, ilustrado pela saída dos quadros políticos reformistas da Previdência Social.

Em 1988, o desenvolvimento do Suds se viu seriamente ameaçado por ocasião da demissão do presidente do Inamps e de sua equipe - quadros do Movimento Sanitário -, pela resistência oferecida por políticos fisiologistas, pela burocracia do Inamps e do Ministério da Saúde, assim como pela oposição do setor privado.

Embora a articulação desses interesses contrários à proposta não tenha conseguido se impor no processo constituinte, teve um papel decisivo na paralisação do processo de implementação das medidas reformadoras estabelecidas na Constituição.

O Governo Collor, empossado em janeiro de 1990, não demorou a evidenciar os dois aspectos marcantes da sua política: as tentativas neoliberais para desmontar políticas sociais - dentre elas, particularmente, a mais estruturada, ou seja, a Reforma Sanitária - e os escândalos relacionados à corrupção generalizada em todos os escalões de governo.

Poderíamos afirmar que, à revelia da lei inscrita na Constituição, os avatares políticos do Governo Collor e do seu Ministro da Saúde marcaram fortemente o setor, afetando o andamento político-sanitário sem deixar nenhuma dúvida quanto à existência da profunda relação entre Reforma Sanitária e democracia.

Entendemos que o avanço na implementação da Reforma poderia necessariamente requerer o afiançamento do processo político-democrático, considerando que ela previa um espaço considerável de participação social na gestão do sistema de saúde e, particularmente, no processo de descentralização do sistema, o qual constituiu a coluna vertebral desse processo.

Por sua vez, dado o caráter profundamente democrático da Reforma, poderiam ser estabelecidas as bases de um importante aprendizado político para o exercício da democracia no percurso de sua execução.

Contudo, o governo, eleito como resultado do processo de democratização do País, não tinha a intenção de percorrer esse caminho. Mais: teve uma atuação de cunho autocrático, valendo-se dos artifícios disponíveis - tais como decretos do poder executivo, normas operacionais etc. -, que emperrou o andamento da Reforma Sanitária.

Com isso conseguiu tolhê-la, uma vez que exercia o poder de veto ante os projetos apresentados pela articulação das forças democráticas. Cabe assinalar 
que alguns aspectos foram cumpridos até porque era impossível para um governo constitucional governar à revelia da Constituição.

Por um lado, a orientação neoliberal da política de governo foi de encontro a uma proposta de caráter reformista como a que tinha chegado a ser contemplada na Constituição. Por outro, o exercício da política do Governo Collor reeditou o velho autoritarismo da política brasileira, marcada pelo clientelismo político e pela corrupção, devidamente incrementada em nível nacional, ao tradicional estilo dos políticos do Nordeste. Com isso, o Governo Sarney foi amplamente superado, chegando a corrupção a constituir-se uma praxe da prática de governo da qual nenhuma área política foi poupada.

Voltando à política de saúde, regulamentou-se primeiro a Reforma Sanitária na Constituição Nacional, em 1988. Posteriormente, as Constituições Estaduais e as Leis Orgânicas Municipais estabeleceram os princípios que norteariam o modelo de atenção e de organização dos serviços de saúde locais, segundo as diretrizes da Constituição. O sistema descentralizado de saúde visava, de fato, integrar um sistema único de saúde com cobertura universal, integralidade das ações, com a participação da comunidade, através dos conselhos locais de saúde.

Conforme já mencionado, o processo de legislação do setor não foi acompanhado pela efetivação da política, criando-se uma situação sui generis como a de se ter apenas conseguido contemplar na Constituição o modelo de saúde a ser aplicado no País, sem as condições políticas necessárias para efetivá-lo. Desse modo, a Reforma Sanitária foi definida no plano legal sem que isso revertesse em melhor atendimento, prevenção ou condições de saúde da população.

No ano e meio transcorrido da aprovação da Constituição até o Governo Collor tomar posse, deu-se prosseguimento, com enormes dificuldades, à descentralização política de saúde. Esta se caracterizou pelo repasse aos estados e municípios da prestação dos serviços de saúde, tal como previsto na proposta da Reforma Sanitária aprovada na VIII Conferência Nacional de Saúde, que teve prosseguimento com o Decreto que criou o Suds, em 1987, posteriormente legislado na Constituição Nacional sob o nome de Sistema Único de Saúde (SUS).

De maneira geral, as unidades eram transferidas sem haver nos estados e municípios as condições gerenciais e/ou financeiras para sustentá-las. Os recursos eram repassados da esfera federal para as instâncias descentralizadas por meio de transferências negociadas por convênio. Isso favorecia aqueles estados 
e municípios que, pelo tamanho e/ou poder de negociação política, tinham melhores condições de barganha com o governo federal. Foram perceptíveis os avanços conquistados na implementação em instâncias descentralizadas nas quais existiu por parte de governadores e prefeitos um compromisso político com a proposta.

A maior dificuldade experimentada pelo processo de municipalização em todos esses anos, nos dois sucessivos governos, foi o repasse dos recursos do Suds e, posteriormente, do SUS.

Santos (1992) constatou que, sendo o orçamento público destinado à saúde proveniente em grande parte do orçamento da seguridade social, este sempre se encontra restringido, visto que os recursos não são recolhidos ou são desviados de maneira ilegal e através de artifícios diversos:

- em 1991 não foi recolhido o montante de 40\% das contribuições das empresas por sonegação ou inadimplência;

- no mesmo ano também não foi recolhida a contribuição de mais de 20 milhões de trabalhadores sem carteira de trabalho que emigraram da economia formal para a informal, devido à recessão;

- foram cobertas as despesas do orçamento fiscal com recursos da Seguridade Social;

- em 1990, 22,1\% do orçamento foram desviados para os Ministérios do Exército, da Economia, da Educação e até para o Governo do Distrito Federal;

- em 1991, o Ministério da Economia reteve 75\% da arrecadação do Fundo de Investimento Social (Finsocial) e das taxações sobre o lucro, componentes do orçamento da Seguridade Social para cobrir outros gastos da União;

- a inclusão, pelo Governo, de gastos que correspondiam ao orçamento de outros Ministérios nos 30\% do orçamento da Seguridade destinados à saúde.

Se a isso acrescentarmos a diminuição geral dos recursos para o setor, não é difícil imaginar as penúrias da Reforma Sanitária. Enquanto em 1988 o gasto em saúde correspondeu a 2,32\% do PIB, em 1991 representava 1,51\% do PIB. ${ }^{47}$

47 Porcentagem calculada a partir dos dados obtidos em: Conjuntura e Saúde, Quadro I (Gastos Sociais do Governo Federal), Rio de janeiro: NUPES, ago. 1992, p.6. 
O processo de implementação da política de saúde é de grande complexidade. Seus desdobramentos, avanços e retrocessos nos diversos planos legislativo, institucional, orçamentário e gerencial do sistema de saúde - obedeceram ao papel de oposição e enfrentamento ao Governo Collor, desempenhado pelas forças reformistas, assim como também às relações de força resultantes do embate de um conjunto de forças políticas. Dentre estas encontram-se os movimentos sociais em saúde, sindicatos, partidos políticos progressistas, intelectuais e acadêmicos da saúde, entidades médicas, técnicos pró-governamentais, setor hospitalar privado, seguros de saúde.

No terreno constitucional, a aprovação da Lei Orgânica da Saúde - Lei Federal 8.080 de 19/9/90 - tornou-se possível graças à articulação das forças políticas em prol da Reforma Sanitária, nucleadas na Plenária das Entidades de Saúde. Analisados em outra parte deste livro, tiveram papel capital na aprovação do capítulo da saúde na Constituição do País.

Essa lei regulamentou o SUS e deu destaque à participação social através das Conferências e Conselhos Nacionais de Saúde. Logo depois de sua aprovação foi vetada pelo Presidente da República, precisamente nos tópicos referentes à participação social (Conferência e Conselhos), à formulação de um Plano de Carreira, Cargos e Salários para o pessoal do SUS, à transferência automática dos recursos da saúde para os estados e municípios e, por último, nos artigos relacionados à reestruturação do Ministério da Saúde no que se refere à extinção e descentralização do Inamps, Superintendência de Campanhas (Sucam) e Fundação de Serviço Especial de Saúde Pública (FSESP).

Diante do veto presidencial fez-se presente uma vez mais a pressão e a articulação da Plenária, conseguindo do Congresso a apresentação de um novo projeto de lei, aprovado em 28 de dezembro de 1990. A nova Lei, número 8.142, sancionada na data de aprovação do projeto, dispôs sobre a realização das Conferências e Conselhos de Saúde e sobre as transferências automáticas para estados e municípios, tornando obrigatórios:

- a criação dos Conselhos Estaduais/Municipais de Saúde e os Fundos de Saúde;

- a programação e a orçamentação;

- o relatório da gestão local;

- a contrapartida orçamentária de 10\%; 
- a formação de uma comissão para a elaboração de planos de carreira, cargos e salários.

A resposta do governo não demorou. Em janeiro de 1991, estabeleceu-se a Norma Operacional Básica no 1 , do Ministério da Saúde, equivalente a um decreto de Poder Executivo, definindo os critérios de repasse para estados e municípios.

Ao contrário do que pregava a Constituição, criou-se um complexo sistema de financiamento com base na produção dos serviços e com igualdade dos pagamentos para diferentes prestadores. A Norma reeditou antigos procedimentos favorecedores da corrupção do setor, especificamente no Inamps, ${ }^{48}$ que continuava a ser o principal gestor dos recursos, mantendo-se a modalidade tradicional de pagamento dos mesmos, ou seja, por serviços.

Em artigo recente, Carvalho et al. (1993) afirmaram que essa norma representou um verdadeiro retrocesso. Ao restabelecer a centralização e o controle dos fluxos financeiros, converteu as transferências financeiras intragovernamentais em pagamentos de faturas por serviços produzidos e colocou em igualdade de condições as empresas privadas, contratadas e conveniadas.

Finalmente, a segunda e última Norma Operacional do governo, datada de 7 de fevereiro de 1992, acrescentou à anterior a adoção do critério populacional para o repasse dos recursos e agregou o repasse automático dos mesmos aos municípios que tivessem cumprido as exigências constitucionais.

O recuo do governo que se depreende do conteúdo da segunda Norma Operacional é explicado por sua importante deterioração, o que o impediu de acrescentar ainda mais obstáculos ao andamento do SUS. O que evidenciou tal deterioração foi o caráter público que adquiriram as irregularidades administrativas no Ministério da Saúde, já tendo estas atingido a figura do Ministro Alceni Guerra. Além disso, as denúncias de corrupção estavam sendo veiculadas pela mídia.

Nesse contexto, o Ministro não tinha autoridade para impor a política de governo. Ainda assim, o repasse dos recursos aos estados e municípios continuou a sofrer o mesmo tipo de dificuldades.

Na realidade, se considerarmos a capacidade de contar com recursos, única maneira de operacionalizar o sistema, evidentemente que o esforço empre-

$\overline{48}$ Entre os últimos atos do Governo Sarney esteve um decreto transferindo o Inamps para o Ministério da Saúde. 
endido pelas forças em prol da Reforma Sanitária se localizou mais no terreno da formulação e da definição constitucional-legal, no qual as forças reformistas concentraram sua luta.

Entretanto, houve certo descaso em termos da factibilidade de implementação, considerando-se as restrições orçamentárias impostas pela crise econômica - inflação, crescimento de economia marginal, desemprego, dívida externa etc. -, à qual se somou a falta de investimento do governo na área social. Os indiscutíveis avanços no plano jurídico não foram acompanhados por um esforço de avaliação e de intervenção diante das dificuldades de financiamento do sistema que foram se apresentando com a implementação da Reforma em um governo que se mostrou hostil ao projeto.

É preciso salientar o caráter sui generis dos avanços alcançados na definição da política de saúde, que, diferentemente de outras experiências nacionais na América Latina, foram conseguidos devido à existência de um movimento político de oposição à política de saúde vigente sob o autoritarismo e pela reformulação desse sistema, que conseguiu acumular forças e travar, também, uma luta política capaz de operar por linhas internas ao Estado.

Em outros países da América Latina - Argentina, Colômbia, Venezuela, México - também surgiram propostas de transformação do sistema de saúde, mas não conseguiram extrapolar o setor específico da saúde, estabelecer alianças e convocar outras forças políticas, nem relacionar as propostas de mudanças no setor às transformações político-democráticas.

Conseqüentemente, dada a dimensão alcançada pela proposta da Reforma Sanitária, a implementação da política de saúde recentemente praticada no Brasil não pode ser analisada independentemente da atuação das forças de oposição ao governo no setor saúde, em razão da capacidade de pressão dessas.

Tal atuação é bem exemplificada pelos obstáculos colocados para o governo pelas forças reformistas, em relação à privatização e ao desmonte da política de seguridade social e saúde. ${ }^{49}$ Em compensação, os entraves colocados pelo governo e pela iniciativa privada na área da saúde obrigaram as forças de oposição do setor a operar sob constantes deslocamentos e redefinições das arenas da luta onde se realizam o enfrentamento e a definição política. Assim, os cenários municipais se tornaram um espaço de luta privilegiado das forças reformistas, assim que o andamento ficou emperrado no nível central.

49 Vide o projeto de governo sobre a privatização da Previdência, nos moldes chilenos, que até hoje não conseguiu passar na Câmara. 
Isso nos leva a concluir que a oposição demonstrou indiscutível efetividade no terreno da luta político-ideológica, considerando que os princípios da Reforma Sanitária ficaram consagrados na Carta Magna do País.

Tendo em vista as dificuldades para que a luta política acontecesse no terreno da transformação efetiva do sistema de saúde, no nível do governo central, e após o término da etapa de definição constitucional da Reforma, houve dois eixos de atuação política nos quais se concentrou a oposição: o convocatório e a realização da IX Conferência Nacional de Saúde, já prevista na Lei 8.142, e o processo de descentralização da política de saúde. Aliás, a descentralização da política foi estreitamente associada à municipalização e esta última definida como o tema central da Conferência: Municipalização é o Caminho. ${ }^{50}$

A idéia aqui defendida é a de reacomodação da estratégia política do Movimento Social em Saúde nas duas direções explicitadas. De um lado, a IX Conferência possibilitaria, como aconteceu, a mobilização da sociedade para pressionar a implementação dos princípios da Reforma através do aprofundamento do processo de municipalização da política de saúde. De outro, tornaria a Reforma menos vulnerável no nível central de decisão da política.

A partir do reconhecimento da dificuldade de se avançar nesse terreno, deuse início ao incentivo aos níveis locais na implementação da política, questão que se sustentou na concepção política que compreendeu a municipalização como deslocamento de poderes e atribuições do nível central para o local, além de processos de democratização da política através da participação social na gestão local.

Cabe a interrogação se essa foi uma estratégia adequada quanto à convergência entre os objetivos e a implementação da Reforma. Ou seja, as restrições sofridas pela descentralização da política no processo de municipalização, por não ter havido uma definição do governo federal que incorporasse as questões contempladas pela Reforma Sanitária - assim como por não terem sido definidas atribuições para os níveis federal e estadual no processo de descentralização -, não conduziram, de fato, a uma fragmentação da política. Em que medida essa fragmentação não contribuiria para diferenciar ainda mais as condições de saúde das comunidades mais necessitadas, acentuando as presentes desigualdades sociais e contribuindo para a reprodução da pobreza?

De fato, o processo de municipalização tal como vem sendo implementado contribuiu para a fragmentação ou a atomização da política de saúde, na medi-

${ }^{50}$ Ver, sobre a IX Conferência, Escorel (1992). 
da em que o sistema passou a depender inteiramente da definição política dos prefeitos em relação à Reforma Sanitária e também da disponibilidade de recursos das prefeituras a serem aplicados no sistema local de saúde. Neste sentido, mais adiante poderá ser constatado como essas questões se equacionaram, a partir do estudo da situação em alguns municípios.

\section{A IX Conferência Nacional de Saúde}

A IX Conferência foi realizada em 9 de agosto de 1992, após sucessivos adiamentos, dos quais o primeiro ocorreu ainda ao Governo Sarney (Escorel, 1992). A realização da IX Conferência significou consideráveis esforços políticos das forças reformistas e uma definição política a respeito da importância decisiva que a mesma teria na vida política nacional e no setor da saúde particularmente.

A VIII Conferência deixara assentadas as bases do papel que o Movimento Sanitário e o Movimento Social em Saúde alcançaram na determinação de qual seria o sistema de saúde mais adequado para o atendimento às necessidades do conjunto da população e, especialmente, das camadas mais pobres.

Porém, na memória das forças de oposição, esse havia sido um espaço conquistado como resultante da luta política do setor, ao qual se chegou devido à existência de um projeto proveniente da sociedade, tendo para isso contado com o apoio de consideráveis forças sociais - Movimento Social em Saúde, profissionais de saúde, usuários -, capaz de se impor ao governo.

Em tal sentido, o espaço da participação social alcançado na VIII Conferência Nacional de Saúde foi preservado, tendo a IX Conferência sido realizada com ampla participação das entidades ligadas ao setor, apesar das dificuldades e prorrogações por parte do governo. Foram inicialmente realizadas as Conferências Estaduais e Municipais - processo que regimentalmente precede a Nacional - e escolhidos os delegados e participantes credenciados.

A etapa preparatória trouxe de volta à cena política o clima de mobilização social alcançado pela VIII Conferência, justamente num momento de paralisação e de perplexidade política que afetou o País e a sociedade como um todo, diante das transgressões éticas e morais do Presidente da República. A título de exemplo da capacidade de mobilização conseguido pelas forças sociais em prol da Reforma Sanitária: na capital de um paupérrimo estado do nordeste brasileiro (São Luís do Maranhão), reuniram-se 500 delegados regionais para a Conferên- 
cia Estadual de Saúde, ${ }^{51}$ representantes dos Conselhos de Saúde, movimentos populares, profissionais de saúde etc.

No espaço de tempo entre a preparação e a realização, o Ministro da Saúde, Alceni Guerra, foi substituído, ou melhor, obrigado a renunciar, porque denúncias de corrupção o implicavam diretamente, o que foi objeto dos primeiros escândalos da administração Collor. O governo, em franco retrocesso, nomeou para o cargo o Dr. Adib Jatene, que se comprometeu com a realização da IX Conferência.

O temário da Conferência incluiria os seguintes pontos: sociedade, governo e saúde; implantação do SUS; municipalização; financiamento; gerenciamento do sistema de saúde e política de recursos humanos e controle social. A Comissão Organizadora contou, entre os componentes, com o Conselho Nacional dos Secretários Municipais de Saúde (Conasems), que conformaram a presidência do Comitê Executivo e cujo documento será discutido à parte, por constituir um dos aportes mais concisos e objetivos em termos de diagnóstico das dificuldades por que passava a implementação da política de saúde.

Dentre os documentos a que tivemos acesso, é interessante fazer referência ao conteúdo dos mesmos, já que se aproximou de um diagnóstico e de propostas para efetivar o SUS.

Os documentos da Plenária Nacional de Entidades de Saúde, do Conselho Federal de Medicina (CFM) e dos Secretários Municipais de Saúde, de maneira geral, são documentos aqui e ali coincidentes em seus aspectos fundamentais, com diferenças no grau de precisão dos diagnósticos e propostas.

Em relação ao financiamento, destaca-se que eram destinados somente 3\% do PIB para o setor saúde, com a proposta de dispor de 8\% a 10\% do PIB a ser investido na saúde, além da recomendação de que fossem destinados de 10\% a 15\% da receita própria de cada esfera de governo à área da saúde, junto com a viabilização imediata dos Fundos Estaduais e Municipais de Saúde.

O documento do Conasems considerou que não se devia permitir a dedução do imposto de renda das despesas com assistência médica privada, devendo-se em contrapartida destinar ao SUS os recursos do seguro obrigatório de automóvel. Esses recursos deveriam ser centralizados no Fundo Nacional de Saúde e transferidos de forma regular e automática aos fundos estaduais e municipais. O Conselho Nacional de Saúde teria que definir os percentuais re-

51 Mesa-redonda intitulada "Sociedade, Saúde e Governo", realizada em setembro de 1991, durante a I Conferência Municipal de Saúde. 
passados a cada instância. Contra a forma de pagamento em vigor por serviços, os critérios adotados seriam populacional e epidemiológico, e de acordo com a capacidade e a complexidade dos serviços de saúde instalados.

Quanto aos Conselhos de Saúde, propôs sua implantação imediata, com caráter deliberativo e composição paritária, conforme o previsto na Lei no 8.142 , tendo o CFM acrescentado que os Conselhos fossem articulados com as redes prestadoras de serviço. O documento do Conasems enfatizou o próprio processo de municipalização, afirmando que a municipalização plena compreendia, além dos recursos financeiros, a gestão efetiva do SUS e o controle social plenamente exercido, salientando não se poder limitar a municipalização a determinada forma operacional - consórcio, distrito sanitário ou outra -, cabendo aos próprios municípios a resolução sobre a forma mais conveniente.

Finalmente, no âmbito dos recursos humanos, defendeu a implementação imediata de um Plano de Cargos, Carreiras e Salários, a formação de recursos humanos em todos os níveis, a valorização da dedicação exclusiva e a integração de recursos humano de diversas instituições. O CFM agregou, em relação ao setor público, isonomia salarial, estímulo ao tempo integral, ascensão funcional. Em relação ao setor privado, foi defendida a garantia de remuneração condigna dos honorários médicos, desvinculando-os das contas hospitalares.

Dentre as propostas e trabalhos apresentados destacou-se, pela maior objetividade e precisão, o documento do Conasems. Coincidentemente, foi o grupo de maior estruturação e articulação política da IX Conferência, o que não foi casual, uma vez que a implementação do SUS, pela própria definição política e tático-operacional do Movimento Sanitário e do Movimento Social em Saúde, ficou nas mãos dos Secretários Municipais de Saúde, levando a municipalização a tornar-se o tema central da IX Conferência.

Genericamente, os documentos restantes foram pouco objetivos: alguns tiveram caráter excessivamente teórico e outros um cunho mais político-ideológico - como o documento da CUT -, não conseguindo exprimir de maneira mais afinada quais deveriam ser os desdobramentos do temário em termos de diagnóstico apurado da situação e os possíveis encaminhamentos ou diretrizes para operacionalizar o SUS. O que esses documentos deixam transparecer são as diferenças nos encaminhamentos e posicionamentos dos diversos grupos que sustentavam o projeto da Reforma Sanitária.

Acreditamos ser esse um fato de suma importância, ou seja, a multiplicidade de grupos com interesses específicos em jogo no setor saúde. Tal constatação 
suscita a questão de como lidar com a diversidade de interesses, já que os favorecimentos da realização de uma determinada ação deixam de ser virtuais para favorecer a uns e prejudicar a outros. Trata-se de questão intrínseca ao exercício da própria democracia e que se atualiza no processo de implementação da política de saúde.

O que interessa ressaltar, no entanto, é que os próprios grupos motores da Reforma, no momento da sua implementação, interagem de maneira particularmente estreita, na medida em que os conflitos internos cobram vulto desproporcional, acirrando ainda mais as divergências entre os interesses dos usuários e os dos médicos.

Necessário se faz, a propósito, destacar a ausência de condução política, pela Reforma, nas forças sociais, o que levou, por exemplo, à adoção de diferentes posições por parte de um mesmo partido político, conforme sua capacidade de expressar os interesses dos profissionais de saúde ou os dos usuários.

Referimo-nos à defesa feita pela CUT com relação aos profissionais de saúde, no que dizia respeito à dedicação de 30 horas semanais no serviço público e à posição contrária dos usuários organizados, representados majoritariamente pelo PT, que defendiam 40 horas semanais de trabalho médico no setor público.

Outro obstáculo de importância é o viés ideológico adotado no tratamento dos Conselhos de Saúde a respeito da relação dos movimentos populares com o Estado, que dificulta discussões mais objetivas e precisas sobre as questões relativas à implementação da política nas discussões levantadas durante a IX Conferência.

A disparidade de interesses entre usuários e profissionais de saúde deve ser considerada chave para as dificuldades na implementação da Reforma, especificamente no que se refere aos médicos. No entanto, colocar na atuação destes o maior empecilho para a implementação da política de saúde não deixa de ser uma simplificação da questão (Escorel, 1992).

Em primeiro lugar, significa atribuir aos médicos, no sistema de saúde brasileiro, um papel que eles não têm. Embora tenham uma responsabilidade ética no atendimento aos pacientes e nos últimos anos tenham mostrado maior preocupação com seus interesses corporativos do que com os valores essenciais do exercício da medicina, eles não deixam de ser apenas uma peça na engrenagem que sustenta a reprodução do Estado no setor específico da saúde.

Inexistem condições satisfatórias de atendimento no sistema público de saúde, salvo meritórias exceções: instrumental, higiene, medicamentos, pessoal 
auxiliar, manutenção das instalações etc. Se às condições de trabalho agregarmos os salários enormemente deteriorados, a falta de formação adequada como resultado dos currículos das faculdades de medicina, o ingresso precoce no mercado de trabalho e as múltiplas inserções profissionais para contornar o empobrecimento, fica evidente o papel secundário que os médicos representam no sistema de saúde.

Quando se compara o papel social e político dos médicos no Brasil, em relação a outros países, podem-se observar as diferenças aviltantes do poder político e a valorização social dos médicos em países desenvolvidos (Gerschman, 1992b). No Brasil, os médicos não deixam de ser mais do que profissionais emergentes de um sistema de saúde obsoleto que resiste a sair de cena.

Em termos de resultados, na IX Conferência:

- conseguiu-se garantir a continuidade do processo de municipalização da política de saúde, de acordo com os princípios constitucionais;

- não houve avanços significativos em relação à operacionalização da Reforma, ou seja, sobre a definição de que lugar caberia aos estados e à federação na implementação da política. Em suma, os resultados da IX teriam ficado aquém dos resultados alcançados pela VIII.

Faltou um diagnóstico/avaliação objetivo do momento atual de implementação do SUS que possibilitasse dar um passo à frente em relação a diretrizes concretas da operacionalização do SUS nos municípios, definindo modalidades mais pragmáticas de intervenção e incidência no montante do orçamento, a forma de pagamento e o repasse ágil dos recursos para estados e municípios. Ou seja, como enfrentar operacionalmente, no geral, o velho sistema de saúde desde as gestões estadual e municipal.

A IX Conferência significou, tal como a VIII, um grande esforço de luta e de mobilização política com a reunião de amplas forças sociais para discutir democraticamente os problemas do setor saúde. Porém, evidenciou um certo esgotamento de um determinado modo de exercício da política apoiado em princípios e/ou questões substantivas. Ainda que estes sejam necessários à formulação da política, são insuficientes para a implementação das reformas, as quais requerem a negociação e a construção de acordos entre parceiros e oposição de maneira a viabilizar as transformações propostas.

As dificuldades observadas resultam também da heterogeneidade na composição das funções e do posicionamento destas no interior do Movimento 
Social em Saúde, à qual se agregou a fragilidade do Movimento Sanitário numa fase de declínio, após ter conseguido, durante mais de dez anos, exercer a condução do movimento social em saúde - e a ausência de uma direção política aceita e reconhecida, como tal, pelo conjunto das facções do movimento social em saúde.

De fato, isso a diferencia também da VIII Conferência, onde o projeto da Reforma Sanitária foi abraçado e reconhecido como legítimo pelo Movimento Social em Saúde, apesar das diferenças internas do Movimento Social como, por exemplo, com referência ao papel exercido pelo Estado, visto anteriormente na Parte II.

\section{A Redefinição da Política de Saúde e a Extinção do Inamps}

Algumas considerações devem ser apontadas a respeito do período político que se iniciou no final de 1992, no Governo de Itamar Franco, sem que pretendamos aprofundar essa linha de discussão, mas apenas destacar algumas questões gerais que podem subsidiar o debate acerca da política de saúde.

O período inicial da gestão de Itamar Franco caracterizou-se pela ausência de definições articuladas em uma proposta de governo e de políticas que viabilizassem o aprofundamento do processo democrático sob a perspectiva da institucionalidade democrática, da redistribuição de renda e da administração da justiça social.

A tônica de governo foi a de evitar enfrentamentos entre interesses conflitantes sem uma direcionalidade política evidente. A composição dos ministérios evidenciou projetos, assim como posições diferenciadas entre os membros do gabinete, sem o estabelecimento de articulações mais amplas, embora o pessoal contemplado com as nomeações não estivesse contaminado pela corrupção.

No caso do setor saúde, ainda que o governo não tenha tido um direcionamento político explícito para a implementação da Reforma, a escolha de um ministro da saúde afinado com a mesma resultou numa gestão caracterizada pela intenção e pela vontade política de aprofundar o processo de municipalização.

Em período extremamente curto - menos de um ano na pasta -, o Ministro da Saúde Jamil Haddad trouxe à discussão o papel e a definição das atribuições que caberiam ao nível central de condução da política para que o SUS pudesse ser efetivado. 
No marco da Constituição do País, além dos decretos que reorganizavam o Fundo Nacional de Saúde e a estrutura transitória do Inamps, constituíram propostas radicais para a implementação do SUS o projeto de lei propondo a extinção do Inamps, em abril do mesmo ano, e o documento publicado em março de 1993 - A Ousadia de Cumprir e Faz̧er Cumprir a Lei.

Nesse documento tratava-se dos encaminhamentos no nível central para a implementação do SUS. Retomaram-se, também, as questões que conformavam o SUS segundo a Constituição, as medidas a serem efetivadas e as atribuições a serem desempenhadas por cada uma das instâncias do sistema de saúde.

Priorizou-se o financiamento, considerando-o um desafio de natureza política que exigiria o compromisso de $10 \%$ a $15 \%$ das receitas de cada uma das três esferas de governo - federal, estadual e municipal - para o setor da saúde. A maneira de dispor do montante de recursos foi discutida, no citado documento, em três pontos-chave: como ampliar a receita num quadro recessivo, como racionalizar o custo da assistência e como erradicar o desperdício.

A respeito do primeiro ponto, não há referência aos lineamentos da política econômica que deveriam ser incorporados para o financiamento do setor. A ausência de definições mais incisivas que revertessem na ampliação dos recursos públicos para a área social, e em especial da saúde, se contrapôs ao empenho das forças políticas conservadoras em mantê-los nos patamares existentes. Ao mesmo tempo, expressa a impossibilidade de recompor um novo pacto político e o impedimento de se avançar no processo de construção da democracia, uma vez que as relações permaneciam pouco transparentes e pouco plurais no setor da saúde. As medidas propostas passavam pelo cumprimento do previsto em lei, como, por exemplo, a garantia de que não existisse sonegação nas arrecadações, cobranças etc.

Transformações mais profundas no financiamento da saúde levariam o setor empresarial de assistência, de medicamentos e de tecnologia médica a perder espaço ou consideráveis cotas de poder. Mesmo que o Presidente Itamar Franco tenha chamado figuras da esquerda política para ocupar cargos governamentais, isso não redundou numa recomposição social e política, ou seja, não se tornou um processo de governo coordenado que expressasse um projeto nacional.

No segundo ponto - como racionalizar os custos da assistência -, embora se considere esta uma questão técnica, não houve uma definição mais clara de qual seria a imagem-objetivo do modelo assistencial - fora o de torná-lo mais eficiente - e de como se poderia alterá-lo. Para erradicar o desperdício, apon- 
tou-se a necessidade de reverter a lógica da prática gerencial vigente, responsabilizando as instâncias pelo controle dos recursos do sistema. Em termos operacionais e atribuições, concluiu-se que:

- à esfera federal corresponderia formular a política nacional de saúde, o desenvolvimento científico e tecnológico, o desenvolvimento de recursos humanos, a regulação do SUS e da atividade privada;

- à esfera estadual, a formulação da política estadual, a coordenação e o planejamento da rede, a supervisão e a cooperação técnica e financeira aos municípios e, supletivamente, a execução de alguns serviços;

- à esfera municipal, a formulação da política de âmbito local, o planejamento e controle das ações e serviços de saúde dirigidas ao indivíduo, ao coletivo ou ao ambiente, incluindo os processos de produção e de consumo dos produtos de interesse para a saúde.

Ainda em termos operacionais, propôs-se a criação de um Grupo Especial para a Descentralização, no Ministério da Saúde, que elaborasse diretrizes voltadas para a viabilização do processo em todas as suas áreas.

A redefinição da esfera federal, conseqüentemente, levou à revisão da organização administrativa do Ministério, para a qual se propôs a criação de grupos-tarefa de profissionais lotados em seus diversos órgãos, funcionando como equipes perenes na condução do plano técnico-administrativo do processo de descentralização e das transformações indispensáveis ao desempenho do novo papel.

Propôs-se, ainda, que esses grupos se constituíssem nas seguintes áreas: financiamento, desenvolvimento científico e tecnológico, recursos humanos, planejamento e orçamento, vigilância epidemiológica, qualidade de assistência à saúde, qualidade de processos e produtos, qualidade do ambiente, incentivo à participação e controle social.

O documento foi aprovado pelas entidades da sociedade, pelo Movimento Social em Saúde e pelos municípios, através do Conasems, que ressalvas em relação a algumas questões, tais como:

- a ênfase quase exclusiva na assistência médica;

- o uso da municipalização como sinônimo de descentralização;

- a falta de uma nítida definição do papel das secretarias estaduais; 
- a necessidade de alianças com segmentos do governo e do Legislativo para concretização das propostas;

- a necessidade de se especificar melhor a relação com os municípios.

A Confederação Nacional da Indústria (CNI), a Associação Brasileira de Fármacos (Abifarma), o Sindicato de Fármacos (Sindifarma) e outras entidades empresariais opuseram-se ao documento, criticando e principalmente sugerindo que não se estruturasse uma municipalização pura e simplesmente, mas sim uma regionalização ordenada e preestabelecida, em função dos fluxos naturais dos usuários existentes na época.

Também propuseram que os orçamentos da União, dos estados e municípios fossem definidos de acordo com os valores alocados, por pessoa, em um ano para o financiamento do serviços. Entre outras questões similares, foi proposto, ainda, que a rede de alta complexidade fosse definida antes de ser ampliado o processo de municipalização. De modo geral, os pronunciamentos dessas entidades visavam especialmente preservar o setor hospitalar privado.

Outra medida ligada à decisão de completar a municipalização foi o envio ao Congresso de um projeto de lei extinguindo o Inamps, que foi aprovado através da Lei no 8.685, em 29/7/93, pelo Senado Federal. Sua criação ocorrera em 1977, pela Lei $n^{\circ}$ 6.439. Tinha a seu cargo a assistência médica prestada por todos os órgãos previdenciários, a centralização e o posterior repasse e controle dos recursos para os serviços de saúde da Previdência e do setor privado conveniado. Representava, assim, um instrumento remanescente e tardio da política de saúde concebida no período autoritário e, portanto distante dos princípios do SUS.

No início de 1990, um dos últimos atos do Governo Sarney foi a assinatura de decreto transferindo o Inamps para o Ministério da Saúde. Mas sua estrutura, organização e competências somente foram definidas em 1991.

As funções que o Ministério de Saúde atribuíra ao Inamps tinham sido o controle, avaliação e auditoria da rede assistencial, a cooperação técnica com estados, municípios e Distrito Federal, além do repasse e do controle de recursos financeiros para a assistência médica. Em suma, o Ministério da Saúde não efetivara alterações substantivas dentro do Inamps, mantendo-o como um órgão superdimensionado e de caráter centralizador da política de saúde, tal como desde a sua criação.

Enquanto isso, a Lei Orgânica da Saúde, regulamentada em 1990, previa o repasse automático e o controle dos recursos financeiros pelo Fundo Nacional 
de Saúde, em franca oposição à manutenção das funções do Inamps, as quais foram reforçadas com a transferência para o Ministério da Saúde.

Um dos problemas históricos do Inamps tem sido o uso indevido dos recursos. Desde a sua criação, a corrupção foi facilitada através da nomeação de cargos de confiança nas direções regionais e nos hospitais, pelo superfaturamento de compras e licitações de material e instrumental hospitalar e, ainda, pelo financiamento dos serviços de saúde - este, ao se sustentar sobre uma forma de pagamento por ato de intervenção médica, acabou por favorecer o excesso de intervenções -, assim como pelo superfaturamento por ações não realizadas.

Para se ter idéia do superdimensionamento do Inamps, no momento de sua extinção, quando o processo de municipalização já havia avançado, o órgão ainda geria 6.500 hospitais contratados, 40.000 credenciados, 9 hospitais próprios, 3 maternidades e 7 postos de atendimento ambulatorial. Dele dependiam 96.913 servidores, distribuídos em coordenadorias regionais, hospitais e postos de saúde, próprios ou cedidos à rede pública conveniada ao SUS, além do que apresentava 65.104 aposentados incluídos na folha de pagamento. ${ }^{52}$

O Decreto no 808 , de 24/4/93, estabeleceu a estrutura provisória até ser aprovada a sua extinção pelo Congresso. Aboliu 550 cargos de confiança do órgão, delegou amplos poderes ao Ministério da Saúde para sua descentralização e adequação ao SUS e ainda lhe atribuiu funções de apoio técnico-administrativo, com relação a esse Ministério, na descentralização das ações de saúde e na administração dos recursos orçamentário-financeiros, patrimoniais e humanos alocados ao SUS.

A extinção do Inamps foi alvo de manifestações que expressavam posicionamentos diversos, salientando uma desorientação muito grande com relação à medida governamental. Os representantes políticos dos partidos conservadores, de hospitais privados e os coordenadores estaduais do órgão não estavam, de modo geral, de acordo com a medida.

As forças políticas que participaram da luta pela Reforma Sanitária não chegaram a uma posição consensual nem a acordos em relação à sua implementação. Parte das fileiras pró-reforma apoiaram a determinação adotada pelo Ministro, propondo que o processo de descentralização deveria aprofundar a transferência de poderes para o nível local - situação favorecida, mas não necessariamente garantida pela extinção do Inamps -, alegando que não se podia confundir descentralização com municipalização.

52 Conjuntura em Saúde. Nupes/Daps/Ensp/Fiocruz, abril de 1993. 
Houve também nas fileiras pró-reforma a suspeita de que se tratava de mais um engodo da política neoliberal, encaminhada pelo governo para ocultar a insuficiência dos gastos públicos destinados à saúde e ao enxugamento da máquina estatal, apenas transferindo a corrupção e o clientelismo para outras instituições do Estado. ${ }^{53}$

A ausência de acordos em torno da extinção do Inamps atualizou as diferenças internas existentes no Movimento Social em Saúde. Neste, cada facção vislumbrava o processo sob a ótica de interesses específicos que ali se dirimiam, sem fixar acordos político-técnicos sobre questões que reforçassem a unidade do movimento, de maneira a enfrentar a oposição à Reforma.

53 Gastão Wagner, no artigo 'Sai Inamps, entra... ?', publicado no periódico Proposta, Jornal da Reforma Sanitária, em abril de 1993. 


\title{
A Descentralização do Sistema de Saúde
}

\begin{abstract}
A descentralização do sistema de saúde em estados e municípios foi o eixo central da implementação da Reforma Sanitária. Esta passou a ter uma base local municipal de considerável importância, já que, com a regulamentação do SUS na Constituição e as Leis Orgânicas, ocorreram transferências dos serviços de saúde para estados e municípios, embora o processo permanecesse incompleto.
\end{abstract}

Isso porque, de um lado, em virtude dos empecilhos que o Inamps e o governo central impuseram ao processo, a transferência de recursos tornou-se difícil e demorada, sobretudo no que diz respeito ao financiamento, que continuou definido no nível central tanto em seu montante quanto em seu repasse. De outro, a continuidade e o aprofundamento do processo de municipalização, em grande medida, ficou ao arbítrio político de governadores e prefeitos, ao que se somou a própria heterogeneidade econômica, populacional e de infraestrutura dos serviços de saúde dos municípios brasileiros.

Uma grande quantidade e diversidade de trabalhos relacionados à descentralização foram desenvolvidos no Brasil nos últimos anos. O processo de democratização do País tem atualizado uma discussão que em si mesma não é recente. A ambigüidade do termo (Jacobi, 1989) e as diferentes conotações atribuídas à descentralização adquirem um interesse específico no processo de democratização (Teixeira, 1989; Campos, 1990) que o País atravessa.

Descentralização, desconcentração de funções e/ou deslocamento de poder formam os diversos aspectos do processo de descentralização política frisados pelos autores. Havendo leituras tão diversas sobre a descentralização, polarizar o debate em termos ideológicos induziria a uma simplificação da temática (Jacobi, 1989; Muller, 1992), sendo mais proveitoso situar a tensão 
centralização-descentralização nos diversos grupos sociais e nas concepções políticas envolvidas na implementação da política de saúde, além de considerar marco de referência desse tipo de análise a concepção de descentralização que associa essa noção à democratização do Estado.

Interessa aqui examinar o atual estágio do processo de municipalização, tentando sublinhar as diferenças entre algumas experiências municipais, discutidas mais adiante, e os motivos que explicariam o motivo pelo qual umas foram mais bem-sucedidas que outras. ${ }^{54}$

Antes da abordagem dos municípios escolhidos, nos deteremos nas restrições e condicionamentos colocados em nível central e estadual pela implementação da política de saúde.

Uma das primeiras questões, a relação entre Reforma e Democracia, foi discutida teoricamente no primeiro capítulo deste livro. Embora acreditando na compatibilidade entre ambas, ou seja, que a democracia comporta qualquer reforma, a efetivação desse princípio teórico requer mudanças institucionais nos aparelhos de Estado - a própria Reforma do Estado. Dentre elas, viabilizar a descentralização da política de saúde, de maneira a alterar a distribuição de poder político entre federação, estados e municípios, com o intuito de alcançar uma redistribuição mais eqüitativa do cuidado à saúde da população no contexto municipal.

O que a implementação da política de saúde evidenciou de forma precisa foi a íntima relação entre saúde e política, tendo em vista que prover melhores condições de saúde às populações necessitadas é questão que não pode ser resolvida sem que o Estado priorize inovações nas políticas sociais em geral, de maneira a enfrentar, por meio destas, os problemas da miséria e da morbidade.

O setor da saúde, pelo grau de desenvolvimento do projeto da Reforma Sanitária e das forças sociais em prol da mesma, constitui o ponto de fratura ou de condensação das contradições do sistema político. Ou seja, considerando o estágio em que se encontra a implementação da Reforma Sanitária e por esta envolver a participação social em sua efetivação, configuram-se pontos de fratura, enfrentamentos e contradições entre essas áreas de política e o próprio sistema político, quando se exige deste maior transparência e accountability nos procedimentos.

54 Dois eixos analíticos vão requerer a nossa atenção: a própria gestão governamental da política de âmbito local, no contexto do estabelecimento da democracia, e a incidência da atuação dos momentos sociais nas experiências de municipalização escolhidas através dos Conselhos de Saúde. 
Tornam-se assim flagrantes que os impedimentos na implementação da Reforma Sanitária não podem ser desvinculados da modalidade de exercício da política do governo federal, a qual não somente compromete a consolidação da democracia, mas também revela a inadequação do Estado ao processo de descentralização em curso.

O diagnóstico do esgotamento do Estado e do pacto de dominação em que este se sustentou, assim como o estabelecimento de um novo pacto, com a conseqüente reestruturação do Estado, mereceram tratamento excelente no trabalho apresentado por Fiori (1992) na IX Conferência Nacional de Saúde. ${ }^{55}$

Ainda que uma profunda reforma do Estado devesse passar necessariamente pela constituição de um novo pacto, caberia às forças reformistas no setor saúde um relevante papel nesse processo, proporcionando maior adequação ao processo de implantação da Reforma e de negociações políticas com aquelas forças do setor saúde não comprometidas com a Reforma, tais como as associações que representam o setor privado da saúde.

É preciso ressaltar, neste momento, um ponto de crucial significação. Apesar do enorme poder convocatório e de mobilização social do Movimento Sanitário e do Movimento Social em Saúde, evidenciado na IX Conferência, não houve liderança política com projeção nacional nas forças reformistas, nem autoridade política que a habilitasse a negociar. Não houve um plano nacional de saúde cuja operacionalização e implementação exigisse a reforma do próprio Estado, nem uma explicitação das mudanças consideradas prioritárias no âmbito do Estado para a implementação da Reforma Sanitária.

Faz-se necessário, ainda, assinalar o papel que atribuímos ao Estado e em que direção deveria ser exercido. Não temos dúvida a respeito do papel central que o Estado deve manter com relação ao mercado e ao setor privado, na sua intervenção como promotor do desenvolvimento econômico e de justiça social.

\footnotetext{
55 "Em síntese, decompor-se, durante os anos 70, o pacto desenvolvimentista, desfez-se sua articulação econômica e sua aliança política, perdendo ademais sua aparente autonomia a coalizão tecnoburocrático-militar responsável pela gestão do governo e da economia durante os vinte anos de autoritarismo desenvolvimentista. Este quadro se mantém durante os anos 80 sem que se afirme nenhuma nova hegemonia, coalizão ou estratégia. E este, para nós, é o núcleo da crise orgânica vivida pelo Estado brasileiro. (...) As transformações que se impõem são radicais e apontam para uma mudança qualitativa do papel do Estado (...) assentada num pacto nacional que incorpore a população até hoje excluída permitirá reformar o aparelho do Estado e dotá-lo da flexibilidade instrumental capaz de viabilizar um Estado ágil - interna e externamente - (...) cujas intervenções sejam definidas por uma estratégia que solidarize os setores empresariais hegemônicos com as burocracias estatais, e estes, em conjunto com os ideais de dignidade e cidadania popular, completamente ausentes até agora da vida política brasileira (...). Só um estado 'forte' (...) poderá cumprir estes objetivos..." (Fiori, 1992).
} 
Essas funções dão-lhe novas atribuições e exigências, de modo que a democracia venha a se confundir cada vez mais com a eqüidade social e as mudanças implementadas se tornem objeto de reflexão, discussão e contínua avaliação dos resultados e da efetividade conseguida através das mudanças implementadas, tais como:

- o desmonte e o redimensionamento dos nichos de ineficiência da máquina estatal e a criação de centros nervosos de decisão da política em que tenham assento e representação os diversos interesses sociais em jogo na sociedade, diante de políticas específicas;

- a incorporação de uma burocracia concursada de alto nível técnico e bem remunerada, a demissão do excesso de funcionários mal remunerados e sem formação adequada e a negociação com o setor privado e/ou a criação de empregos para a alocação desses funcionários dentro de um prazo razoável;

- por último, a aproximação, por parte do Estado, das experiências locais de gestão, fundamentalmente nas áreas de política social, estendendo o processo de descentralização do setor saúde às áreas de política social restantes.

Neste sentido, quando mencionamos Reforma do Estado não estamos nos referindo a uma reforma exclusivamente administrativa, o que seria impraticável. Nenhuma reforma administrativa per se garantiria o encaminhamento da Reforma Sanitária tal como consagrada na Constituição.

Sua implementação requereria, também, uma recomposição das alianças políticas e de relações de forças entre interesses e grupos - as burocracias e os médicos empregados no setor público/privado, os representantes do setor privado, profissionais de saúde, movimentos sociais, usuários, sindicatos etc. Tratase, portanto, de questão a ser pensada pelas forças reformistas.

Se nos detivermos agora nas restrições que em nível central se colocaram para a operacionalização do SUS, a primeira a se destacar é o orçamento nacional destinado à saúde. Escassos 3\% do PIB inviabilizam totalmente um sistema universal e público de saúde - o SUS -, enquanto os dados sobre gastos destinados à saúde nos países desenvolvidos registravam em torno de $10 \%$ do PIB.

Desse modo, não poderia ser aceita uma depreciação do orçamento da saúde dessa magnitude, pois o patamar de 10\% do PIB é exigência para a 
implementação da política. Não existe margem de discussão a esse respeito, já que se trata de exigência inelutável para a implementação da política. Posta essa questão como de caráter inegociável entre as forças reformistas e o governo, obriga-se este a redefinir uma política orçamentária nacional, o que aciona um mecanismo em múltiplas direções por ser o orçamento da saúde vinculado à definição da política econômica nacional.

Conseqüentemente, decisões desse tipo envolvem a orientação da produção nacional, as prioridades de investimento, as dívidas externa e interna, as políticas fiscal e bancária, a própria estrutura do Estado e todos aqueles fatores que definem um projeto nacional de desenvolvimento conceitualmente sustentado na redistribuição de renda e na transferência de poderes para os níveis locais do exercício da política.

Já no plano mais específico dos recursos financeiros destinados ao setor, ainda se faz necessário abolir o repasse dos recursos para estados e municípios na forma de pagamento pela produção de serviços (Unidade de Cobertura Ambulatorial/UCA e Autorização de Internação Hospitalar/AIH). Esse talvez seja o ponto no qual vão assentar-se a reprodução do sistema de saúde e a produção de serviços de saúde.

Ao se levar em conta que o sistema de saúde deve ser sustentado num modelo de produção de serviços médicos e que a produção de qualquer bem na sociedade capitalista é regido pelas leis do mercado, ou seja, que aquele que dele quiser usufruir terá de pagar por isso, fica evidente que cada ato de intervenção médica terá seu correspondente pagamento, seja no consultório particular ou no serviço público.

Assim, quanto maior o número de intervenções médicas, maior a quantidade de ordens de pagamento, ainda que o paciente não pague de seu próprio bolso, ou seja, que o Estado é quem cumpra essa função.

Enquanto o sistema de saúde estiver condicionado à produção de serviços, a saúde continuará a ser compreendida não como direito de cidadania, mas como bem a ser possuído e, portanto, condicionado à aquisição privada ou pública. Essa é a lógica que se estende da relação médico/paciente ao sistema de saúde, decomposto nos seus fundamentos.

Por essa ótica, assim como a saúde não é um direito do cidadão e um dever do Estado, ainda que contemplada pela Constituição, a atribuição dos recursos para o setor não consegue se desprender do modelo liberal de atenção à saúde (Campos, 1992). Na questão do financiamento e na modalidade 
do repasse dos recursos reside um dos pontos-chaves para a mudança do sistema de saúde. ${ }^{56}$

Embora a definição dos critérios a serem aplicados para o repasse de recursos tenha dependido da regulamentação do Artigo 35 da Lei no 8.080, até os dias atuais, o documento elaborado pelo Conasems para a IX Conferência reafirmou o estipulado pelo Artigo 3 da Lei no 8.142. Este estabeleceu que deveria ser respeitado o critério populacional até a regulamentação da Lei $\mathrm{n}^{\circ}$ 8.080, e agregou a manutenção da rede hospitalar e ambulatorial, além dos investimentos das ações de saúde coletiva e os novos serviços executados diretamente pelos municípios, mas sem incorporar o critério epidemiológico, o perfil demográfico da população e a capacidade instalada.

O montante dos recursos a serem repassados a cada um dos estados e municípios deveria ser, portanto, uma resultante de análise e reflexão, por parte das autoridades nacionais e do Conselho Nacional de Saúde, e ser incorporada na elaboração de um Plano Nacional de Saúde.

Outra questão diz respeito às atribuições correspondentes a cada uma das instâncias de governo implicadas no processo de descentralização. Se bem que essa remeta a uma discussão conceitual relacionada à própria noção de descentralização, a perspectiva que nos interessa aqui destacar relaciona-se à presença ou à omissão dos órgãos centrais na política, assim como aos incentivos utilizados pelos órgãos federais para estimular a autonomia político-administrativa das instâncias descentralizadas no processo em curso.

Em nível federal, o que se observou até recentemente foi o esvaziamento da política, que se manifestou na ausência do papel regulador do Ministério da Saúde e do Conselho Nacional de Saúde no processo de municipalização. Assim, a falta de um Plano Nacional de Saúde que contivesse as diretrizes básicas que guiariam a implementação do SUS levou a uma descentralização administrativa do sistema de saúde em que faltaram incentivos para uma efetiva autonomia política e administrativa dos municípios.

Essa omissão, por parte do Estado, em relação a seu papel regulador central, também facilitou medidas de caráter casuístico resultantes das negociações políticas entre os tradicionais parceiros da saúde - políticos clientelistas, setor privado.

56 Campos (1992) afirma, a partir de uma perspectiva muito próxima a essa, que não se pode pensar em mudanças enquanto se mantiver um modelo liberal de atenção à saúde. Considera, contudo, que os médicos constituem "um dos principais fatores que têm impedido a efetiva transformação do modelo de assistência médico-sanitária brasileiro”, questão à qual retornaremos. 
Se nos reportarmos ao ano de 1992, dois fatos ilustram adequadamente a afirmação anterior: a ausência de uma política orçamentária nacional e de saúde levou o Ministro da Previdência a resolver, repentinamente, não repassar mais recursos para estados e municípios, logo após a decretação do estado de falência do seu ministério. Simultaneamente, a inexistência de um Plano Nacional de Saúde possibilitou ao Ministro da Saúde fazer uso, sem consulta, do Fundo de Amparo ao Trabalhador (FAT) para pagar aos prestadores vinculados ao setor privado.

As relações dinâmicas de poder entre atores envolvidos, consolidadas diferenciadamente na história das instituições de saúde, voltam a inclinar a balança da maneira habitual. Estados e municípios ficaram prejudicados pela disponibilização e utilização dos recursos financeiros definidos exclusivamente pelo governo federal (Previdência e Saúde), situação favorecida pela ausência de diretrizes orçamentárias contidas num plano nacional de saúde de extensão nacional.

As restrições da política em nível estadual, em razão da ausência de instrumento político dos estados no processo reformador, atualizaram e agravaram os problemas do nível central. Mendes (1992) suscita alguns pontos que parecem de importância no nível estadual de descentralização.

Em primeiro lugar, a retirada das secretarias estaduais da operação da rede de serviços de saúde obrigaria a uma reorientação político-administrativa que as readequasse às novas funções e atividades necessárias ao processo de descentralização. Neste contexto, o papel das secretarias passaria a ser de caráter político-estratégico na condução das políticas de saúde e na definição das diretrizes municipais.

As secretarias estaduais deveriam, de acordo com as atribuições a elas conferidas pela Constituição, ter a seu encargo as relações com o setor privado, através de instrumentos de direito público. Deveriam também assumir a execução direta de serviços que, pelo nível de cumplicidade, não poderiam ser assumidos pelos municípios e de programas de insumos críticos para o conjunto do Estado.

O controle epidemiológico e sanitário deveria ser realizado também pelos estados, assim como o exercício de funções normativas e de avaliação e o controle das ações descentralizadas, não mais em termos contábeis e financeiros ou em atos médicos finais, mas sobre bases epidemiológicas e sanitárias, o que colaboraria para mudar o modelo de atenção à saúde. Por fim, caberia da 
mesma forma aos estados desempenhar um papel redistributivo de recursos em relação aos municípios, como parte do processo de avaliação.

A efetivação dessas políticas exigiria a não-interferência do nível central e a definição da autonomia administrativa que fizesse das secretarias estaduais gestores efetivos e únicos do SUS nos estados.

A descentralização real das decisões políticas não é factível sem a autonomia dos níveis inferiores, aos quais corresponde decidir e implementar a política e ampliar a participação dos atores sociais envolvidos na mesma. Ao pensarmos o processo de descentralização nessa direção, não nos propomos afirmar que necessariamente a descentralização implique uma democratização da política.

O que se quer destacar é que, ainda que a descentralização não garantisse per se a ampliação da participação dos cidadãos na tomada de decisões por haver uma efetivação político-administrativa do processo de descentralização contemplado pelo SUS, esta favoreceria indiscutivelmente a democratização da política de saúde, na medida em que criaria condições para viabilizar instâncias locais de participação geradas pela própria população e/ou suas entidades representativas.

Tornam-se sumamente complexas a análise e a avaliação do processo de municipalização se considerarmos que, no total, 4.973 municípios extremamente heterogêneos conformam o território nacional. Assim, foi necessário um recorte que viabilizasse o tratamento da questão, de maneira a facultar parâmetros iniciais de avaliação a respeito da implementação da política de saúde em nível municipal.

Trataremos, a seguir, de um restrito estudo de casos sobre o atual estágio da política de saúde em alguns municípios brasileiros, visando estabelecer certas comparações entre eles conducentes a aproximações que, ainda que não possam ser consideradas conclusivas ou significativas em termos do conjunto dos municípios, evidenciam indícios que contribuem para um enfoque metodológico disponível em futuras análises da implementação da política nos municípios brasileiros.

A primeira classificação estabelecida pelos estudos sobre municipalização baseia-se no tamanho da população, diferenciando municípios de grande porte, médios e pequenos. Não há consenso na bibliografia especializada nem entre os pesquisadores especialistas no tema - nacionais e internacionais - a respeito de uma classificação única do tamanho dos municípios.

O Instituto Brasileiro de Administração Municipal (Ibam) tem por critério considerar como pequenos municípios os que têm até 10 mil habitantes, 
médios entre 10 mil e 50 mil habitantes e grandes os que contam mais de 50 mil habitantes. Sendo esse critério não prescritivo, vale o que for definido pelo pesquisador.

Tentando compatibilizar o número de habitantes e o fator desenvolvimento, vamos considerar que nos municípios de grande porte se agrupam as cidades capitais dos estados e outras grandes cidades do País que normalmente coincidem com os municípios de maior importância e desenvolvimento econômico-social regional. Os municípios de porte médio correspondem a níveis intermediários de população, atividades produtivas e desenvolvimento. Os de pequeno porte são municípios agrícolas de escasso ou nenhum desenvolvimento.

De qualquer forma, persistem ainda grandes diferenças internas nesses agrupamentos, difíceis de serem classificadas e reagrupadas e que se relacionam com a história do município, o tipo de população, as migrações, o tipo de atividade produtiva, ingressos, educação, tradição cultural etc.

Partindo desses critérios de classificação, escolhemos de maneira aleatória, para a análise, alguns dos municípios com registros/informações das experiências de municipalização implementadas, sobre os quais existe consenso nas publicações especializadas ${ }^{57}$ sobre os avanços conquistados no que diz respeito ao processo de descentralização.

Dentre os grandes municípios serão analisados São Paulo (SP) e Rio de Janeiro (RJ). Dos municípios de médio porte discutiremos Santos (SP) e Manaus (AM) e finalmente, entre os pequenos, escolhemos Manhuaçu (MG) e Icapuí (CE). São experiências as mais diversas quanto às variáveis selecionadas, mas procuramos agrupar os valores encontrados de maneira tal que nos forneçam base comparativa para a análise.

Em relação aos municípios escolhidos, poderíamos afirmar, de um lado, que apresentam a mesma heterogeneidade que caracteriza os municípios brasileiros. De outro, que nosso interesse focalizou os municípios onde houve certo avanço na política de municipalização, segundo o critério adotado. De modo geral, podemos assegurar que quanto maior o município, maior a complexidade das questões envolvidas e conseqüentemente as dificuldades na implementação da política.

\footnotetext{
Entre tais publicações, podemos destacar: Saúde em Debate, periódico do Cebes (Centro Brasileiro de Estudos de Saúde); Proposta, Jornal da Reforma Sanitária, do Radis/Fiocruz (Reunião, Análise e Difusão de Informação sobre Saúde); Edição Médica, órgão oficial da SMCRJ (Sociedade de Medicina e Cirurgia do Rio de Janeiro); Cadernos de Saúde Pública, da Ensp/Fiocruz (Escola Nacional de Saúde Pública).
} 
Se nessa divisão interna entre municípios há variações no ritmo, na profundidade e nos resultados, existe, todavia, certo consenso a respeito da importância da orientação político-partidária das prefeituras no andamento da política nos trabalhos que tematizaram o processo de municipalização da política de saúde no Brasil. Uma outra questão considerada como positiva é a existência dos Conselhos de Saúde e o grau de mobilização da sociedade em torno da proposta.

De fato, seriam essas as condições prioritárias para o desenvolvimento do processo de municipalização. No entanto, permanecem as diferenças em relação aos pontos mencionados quando observamos a não-existência de certos requisitos de natureza política, mas que exigem procedimentos técnicos, dentre os quais destacamos o incremento de recursos orçamentários no setor saúde, o diagnóstico do quadro sanitário da população do município e o plano de saúde correspondente à abordagem da implementação da política, com particular ênfase no enfrentamento dos problemas de saúde detectados.

Constituirão pontos a elucidar os resultados alcançados na operacionalização da rede de serviços e de atendimento dos usuários e em que medida as reformas administrativas empreendidas pelos municípios, no setor saúde, possibilitaram maior participação dos usuários no sistema de saúde municipal.

A avaliação dessas questões requereria dois planos de análise em contígua interação, e portanto, um esforço redobrado para distinguir quais os elementos essenciais que conduziriam à compreensão do processo de municipalização da política de saúde. Por um lado, poderíamos lidar com indicadores e/ou resultados estatísticos que nos informassem a respeito da melhoria ou não na qualidade dos serviços e do atendimento à saúde, ou seja, o seu impacto sobre a população, vertente de análise que não vamos considerar aqui. Por outro lado, veremos o processo de municipalização como um processo político que envolve a própria democratização não só da saúde, mas do Estado e da sociedade.

$\mathrm{Na}$ realidade, o desenho político-institucional construído na última década e meia da história da política de saúde, que se convencionou chamar de Reforma Sanitária, teve por princípio orientador a ampliação da participação social e a constituição da cidadania na construção da democracia. Em que medida a municipalização da política de saúde na implementação do SUS viabilizou ou não tais princípios constituirá o eixo da discussão dos casos. 


\section{Município de São Paulo}

O município de São Paulo é o maior do País, com aproximadamente oito milhões de habitantes. No período que se estende de 1989 a 1992 a Prefeitura esteve a cargo do Partido dos Trabalhadores (PT), tendo promovido uma ampla reforma administrativa na Secretaria de Saúde com a finalidade de implementar o SUS. ${ }^{58}$

Foram então criadas dez Administrações Regionais de Saúde (ARS), subdivididas em 44 distritos, dos quais 32 estavam em funcionamento. Por sua vez, nas ARS e Distritos Sanitários (DS), criaram-se Conselhos Técnico-Administrativos compostos por integrantes de todos os níveis, incluídas as próprias unidades de saúde.

As ARS contavam com Direções Regionais que funcionavam como Secretarias de Saúde Regionais. Os DS concentravam a atividade de planejamento, coordenando e gerenciando os programas e as unidades sob sua jurisdição.

Os Conselhos de Saúde foram estabelecidos no nível municipal, regional, distrital e nas Comissões de Gestão dos Serviços. Nos Conselhos de Saúde, a representação dos usuários correspondeu a $50 \%$ do total de membros. A representação paritária dos usuários em relação aos trabalhadores de saúde e administradores do sistema foi estipulada na I Conferência Municipal de Saúde, realizada em 1990.

Essas reformas recompuseram a estrutura administrativa da Secretaria Municipal em quatro níveis: central, regional, distrital e local. O que se constata, a partir dessas informações, é que no município de São Paulo houve uma efetiva descentralização administrativa do setor saúde, junto a um processo de ampliação da participação popular na gestão municipal.

É necessário destacar que os grandes municípios, dentre eles São Paulo, tinham uma rede de serviços muito extensa, correspondente ao estado e às vezes à federação. Sua municipalização, em geral, não se operou completamente e, mesmo quando aconteceu, não foi acompanhada do repasse dos recursos do estado e/ou da federação para o município.

A Prefeitura de São Paulo destinou 13\% do orçamento municipal para a saúde, porém não conseguiu integrar ao sistema as unidades de emergência, que, pela legislação, corresponderiam ao município, nem as unidades do estado.

\footnotetext{
8 Os dados discutidos em relação ao município de São Paulo foram obtidos do trabalho "Participação popular e gestão de serviços de saúde: um olhar sobre a experiência de São Paulo" (realizado por Amelia Cohn, Paulo Elias e Pedro Jacobi) e do periódico Conjuntura em Saúde (jul a out, nov/ 1992 e mar, abr, maio e jun/1993).
} 
Segundo levantamento feito pelo Sindicato dos Trabalhadores na Área de Saúde em 17 hospitais da Grande São Paulo, existiam 2.557 leitos desativados e havia também um déficit de $50 \%$ de médicos, $73 \%$ de enfermeiros e $41 \%$ de pessoal de enfermagem.

Ainda em relação à rede estadual, agregou-se à falta de recursos o esquema político do governador do estado, que obedeceu aos moldes tradicionaisclientelistas do PMDB, pelo qual as direções dos hospitais eram submetidas a interesses político-partidários segundo negociações e arranjos convenientes à condução do partido do governo estadual.

Neste sentido, e para exemplificar a afirmação anterior, constatamos que o Hospital de Heliópolis, construído pela Previdência Social, estadualizado em 1988 e um dos maiores do estado - possuía 440 leitos e era considerado de referência em cirurgia -, reduziu o número de atendimentos nos últimos meses por falta de material e de pessoal. Esse fato foi significativamente registrado após a mudança da direção do hospital, ${ }^{59}$ feita pela Secretaria Estadual para atender a interesses de vereador do PMDB. Na verdade, trata-se de regra e não exceção nos estados brasileiros.

De qualquer modo, em relação ao município há indicadores de melhoria na gestão da rede própria: os recursos humanos da saúde aumentaram em 74\% nos quatro anos de gestão do PT, o número de leitos dobrou e incrementou-se a operação dos mesmos, alcançando taxas de ocupação de $86 \%$ e reduzindo a mortalidade hospitalar de 7,4\% para 5,0\% em 1992. Os salários dos profissionais de saúde tiveram reajustes constantes, o que significou importantes mudanças na qualidade de atendimento e na dedicação dos médicos à função.

Em pesquisa realizada no Centro de Estudos de Cultura Contemporânea (Cedec) por Cohn, Elias \& Jacobi (1993), foram ressaltados, a partir de entrevistas realizadas com administradores do sistema e com usuários, os pontos de estrangulamento após os primeiros dois anos da implementação do SUS. Os resultados da investigação são os seguintes:

- os diretores de região e de distrito apontaram para a falta de uma compreensão mais clara sobre o papel dos Conselhos de Saúde e de como concretizar a proposta de participação popular;

- indicaram a necessidade de definir prioridades na programação das atividades das unidades;

59 Folba de S. Paulo, 17/06/92. 
- declararam as dificuldades na gestão dos recursos humanos devido às resistências para modificar a prática tradicional junto aos recursos corporativos, utilizados pelos funcionários para se proteger das mudanças;

- explicitaram que em algumas regiões também ocorreram dificuldades para implementar os Conselhos de Saúde, em conseqüência das tensões entre funcionários e população.

Um aspecto que enfatizaram como dos mais complexos foi a expectativa interna de alguns movimentos face à sua institucionalização pela experiência da participação na gestão pública. Essa questão foi analisada no capítulo relacionado aos movimentos sociais em saúde, mas a retomaremos mais adiante, já que não deixa de ser um paradoxo que, precisamente em uma administração progressista e de caráter popular, não tenham sido aliviadas as dificuldades para lidar com usuários e com movimentos populares em saúde, permanecendo o dilema da institucionalização do movimento como um impedimento de uma inserção mais incisiva desses movimentos na política.

Os investigadores concluíram, a partir das entrevistas com os representantes dos usuários, que as direções das unidades encontraram com quem dialogar na formação dos Conselhos onde havia um movimento popular organizado. Porém, onde este não existia, as dificuldades ampliaram-se devido à falta de uma política clara de representação, bem como de uma agenda para a sua formação. Havia pouca institucionalização da experiência, e a relação dos representantes com os representados ocorria de maneira informal: o 'boca a boca', a vizinhança etc.

O funcionamento regular dos Conselhos se ressentiu, também, da falta de definições mais nítidas, sendo "a boa vontade ou não dos diretores em explicar as coisas com clareza" um dos critérios mais utilizados para o julgamento que os usuários fizeram sobre o papel da direção.

Algumas observações merecem ser destacadas, dentre as quais consideramos que se deve dar especial atenção à relação entre a necessidade de um conhecimento técnico-político mais apurado do setor saúde e os problemas derivados da falta de experiência política na gestão de governo, por parte do PT, numa prefeitura que é das mais complexas do País.

Outro ponto a enfatizar refere-se ao próprio exercício da democracia, quando se trata de atores políticos - os partidos - e de atores sociais - usuários e movimentos sociais - que nunca vivenciaram uma experiência democrática de gestão política. Portanto, não há um conhecimento político acumulado nem 
clareza quanto à implantação de inovações políticas que aproximem os serviços de saúde aos usuários. Exemplificam a nossa afirmação as observações sobre a falta de adequação entre a proposta e sua concretização, a necessidade de definir prioridades, a falta de entendimento dos trabalhadores de saúde e as diferenças entre usuários e administradores.

Questionamos sobre qual a melhor forma de gerir as unidades de saúde e até onde inovar, quais os benefícios recebidos por se implantar formas de cogestão e, nesse caso, de que tipos e de que maneira; as vantagens da maleabilidade na administração segundo o tipo de unidades de saúde; as questões de saúde prioritárias e com que instrumentos abordá-las; por onde começar e como prosseguir; como lidar com recursos escassos e com um governo estadual que responde aos velhos cânones partidários e que, conseqüentemente, dificulta inovações democráticas.

Uma das questões que, em nossa opinião, é de extrema delicadeza e de singular importância diz respeito ao financiamento dos sistemas locais de saúde, na medida em que a obtenção de recursos possa ser condicionada, pelas autoridades locais, ao grau de mobilização da população. Através de uma gestão democrática impõem-se novas formas de atuação dos movimentos populares em relação à implementação da política, mas também modalidades de gestão e, conseqüentemente, de aplicação de recursos que obedeçam a lógicas redistributivas não atreladas a formas clientelistas. Esse perigo pode ser assim exemplificado:

Existe um forte consenso entre os que participam desses processos de que quanto mais sólida a organização e mais intensa a mobilização maior a eficiência dos serviços e mais prontamente um serviço vê suas reivindicações atendidas. Ora, como se trabalha em um quadro de grande precariedade e sobrecarga dos serviços de saúde do Município de São Paulo, apesar da expressiva participação da Secretaria de Saúde no orçamento municipal (de 10 a 15\% no período), as várias regiões (e, em cada uma delas, as unidades de saúde) acabam por ter de competir entre si pelos recursos. $E$ isso acaba sendo uma realidade difícil de ser enfrentada, sobretudo para os movimentos populares, que entendem e pensam os interesses da população como sendo semelhantes e portanto comum a todos. (Cohn, Elias \& Jacobi, 1993)

No exercício da democracia, a participação popular adquire um significado diverso daquele de 'mobilização popular'. Esta, como única alternativa política para a obtenção de demandas, correspondeu a um estágio do exercício da 
política ligado à formação desses movimentos sociais no regime autoritário. Com uma gestão partidária, que busca representar os interesses dos trabalhadores e das populações carentes, torna-se prioritária a formação de ossaturas institucionais inovadoras para o exercício das funções políticas, na esfera de governo, que contemplem a dinâmica das relações entre o próprio partido governista e os movimentos na sua relação com as instâncias governamentais.

Já não cabem as mobilizações na porta das prefeituras como única maneira de esses movimentos se expressarem politicamente. Não que elas deixem de existir, mas não poderiam vir a ser o modo principal de exercício da política na democracia. De qualquer modo, os resíduos de um momento político anterior e a modalidade tradicional de exercício da política são ainda mais fortes que a tendência às inovações políticas democráticas. Um bom exemplo disso foi o manejo do PT sobre os recursos para as unidades de saúde, citado antes, onde os mesmos eram negociados com os movimentos populares em troca de mobilização, estabelecendo-se a regra sobre a qual quanto maior a mobilização popular, maior a quantidade de recursos.

O problema dos recursos - um dos mais sérios na implementação do SUS, por ser objeto de desvio político, tema ao qual já nos referimos - não poderia ou deveria continuar acontecendo, ainda que sob outras formas, com uma administração popular. Os movimentos populares não podem ser arte e parte. Na verdade, trata-se de um procedimento que descaracteriza a participação popular na medida em que a participação torna-se pouco determinante na implementação da política. No momento em que isso acontece, o movimento popular passa a ser instrumento de negociação política entre facções do partido ou de autoridades e a mobilização popular torna-se provedora de recursos.

Se efetivamente os Conselhos de Saúde fossem deliberativos em relação à política, seriam instâncias que, nos diferentes níveis da implementação da política (municipal, regional, distrital, unidades), teriam uma função redistributiva em relação aos recursos e para cujo desempenho os movimentos populares precisariam se habilitar. Mas, por não ser assim, cabe indagarmos sobre esse contrasenso, ou seja, o movimento popular precisar negociar consigo próprio os recursos a serem aplicados nas unidades.

O processo iniciado pela Prefeitura de São Paulo teve uma duração extremamente curta - somente quatro anos - e os resultados alcançados não foram significativos em relação à melhoria da rede de serviços e às condições de saúde da população. Os hospitais municipais, os que pertenciam ao município antes 
da municipalização, foram mais bem reequipados e receberam maior número de leitos. Houve, também, melhoria na gestão dos recursos humanos do sistema, o que redundou em melhoria da qualidade no atendimento médico e na diminuição das greves no setor.

Os programas implantados não tiveram um desenvolvimento notável, nem se verificaram mudanças significativas nos indicadores de saúde da população nesses anos. Sob a perspectiva política em geral, o processo ampliou a participação dos usuários e dos movimentos populares na implementação do SUS e trouxe à tona, principalmente, as dificuldades intrínsecas à democratização, como as diferenças presentes (de organização, cultura, linguagens) entre os diversos atores envolvidos, a pluralidade de interesses e a carência de procedimentos institucionais que facilitassem a tomada de decisões.

A política deixou de ser arbitrada externamente para passar a ser uma condição a ser desenvolvida pelos próprios atores entre si e na relação com os outros. Neste sentido, há um processo de mudança social e 'subjetiva' - no sentido do sujeito - que não tem unicidade nem previsibilidade, mas que promove rearranjos nos comportamentos políticos dos diversos atores.

A experiência de participação popular nos Conselhos de Saúde tem sido, para esses atores, desencadeadora de transformações na concepção do que seja a gestão política e sua complexidade, assim como na consciência da necessidade de possuir conhecimentos que os habilitem a desempenhá-la melhor (Cohn, Elias \& Jacobi, 1993).

Considerados assim, os processos de democratização têm um valor em si mesmos, ainda que resultados imediatos não possam ser alcançados em termos de nova ordenação social e política.

A gestão do PT na prefeitura acabou em fins de 1992, após as eleições municipais. Como resultado destas, produziu-se uma mudança total de orientação, já que o PMDB venceu as eleições, tendo então assumido o governo do estado Paulo Maluf, antigo político de moldes clientelistas, conhecido pelas denúncias de corrupção no manejo da 'coisa pública' durante o regime militar. Os resultados dessa mudança política logo se tornaram visíveis, tendo a situação da rede municipal voltado a se assemelhar à da estadual.

O Sindicato dos Médicos de São Paulo realizou uma pesquisa em março de 1993, cujos resultados indicaram que, dos 21 mil leitos existentes nos hospitais do estado, 8.610 encontravam-se desativados, o que correspondia a cerca 
de $41 \%$, constatando-se também um déficit considerável de médicos, enfermeiros e pessoal de enfermagem.

Ficou constatado também que havia 500 leitos desativados - cerca de 20\% - dentre os 2.557 existentes na rede municipal, ao passo que a rede básica só funcionava três vezes na semana por falta de equipamento e pessoal. Os grandes complexos hospitalares - Hospital das Clínicas e Mandaqui - passaram a atender apenas a emergências. Em outras unidades hospitalares houve reincidência de greves de médicos e de funcionários, e a própria Secretaria Municipal de Saúde manifestou-se, através da imprensa, para afirmar que esses acontecimentos eram resultado dos baixos salários e da conseqüente perda de médicos.

A política salarial de reajustes constantes da gestão anterior foi interrompida pelo novo prefeito logo após ter assumido o cargo. Assim, enquanto em 1990 o salário dos médicos alcançava o equivalente a US\$1.000, em abril de 1993 não chegava a US\$ 340. No município, enquanto 900 médicos pediram demissão naquele ano, houve falta de quatro mil médicos no estado, segundo dados do SinMed. Ameaçando a sobrevivência do setor público da saúde, a situação acentuou-se quando a greve completou um mês em toda a rede estadual.

Quando as crises no setor saúde chegam a esse extremo, produz-se uma reação em cadeia em todos os níveis do sistema. Se a rede estadual deixa de funcionar, não só os pacientes deixam de ser atendidos, como também os hospitais ficam abandonados, sem a manutenção necessária do instrumental e da aparelhagem, o cuidado com as instalações e a limpeza. Dessa forma, os doentes antes atendidos pela rede estadual passam a freqüentar a rede municipal, sobrecarregando e impossibilitando também o atendimento nesta, a qual também sobrevive com dificuldades, sucateada de profissionais e de equipamentos. As conseqüências quase evidentes são o desmonte dos serviços públicos, justificado pelo enorme descrédito da população em relação aos mesmos e à propagação de um certo consenso a respeito da inviabilidade do setor público da saúde, espaço que é rapidamente aproveitado pelo setor privado

A continuada falência do setor público é sinônimo de mais mercado a ser ocupado. Só que dessa vez (...) esses atores em conjunto apresentam uma proposta de um sistema nacional 'alternativo' de saúde (...) a conformação de um sistema que sozinho poderia congregar em torno de $80 \%$ da capacidade instalada no país gerida fora do aparelho governamental (...) para um sistema que oferece cobertura a $30 \mathrm{mi}-$ lhões de pessoas, não seria difícil alcançar algo em torno do dobro 
dessa população, desde que ampliem-se as alianças, o que significaria próximo dos $50 \%$ da população brasileira... O resto viveria de assistencialismo mesmo. (Conjuntura em Saúde, maio de 1993)

A crítica situação do estado e do município não teve solução e o prefeito acabou por adotar uma medida caracteristicamente aleatória, tendo então demitido o Secretário Estadual e o Secretário Municipal quando foram constatados, pela Comissão de Direitos Humanos da OAB, a precariedade no funcionamento de um dos maiores hospitais do estado e o tratamento desumano oferecido aos pacientes.

Assim, os avanços atingidos pelo processo de municipalização foram profundamente abalados no município de São Paulo, como resultado da regressividade das mudanças políticas inauguradas pela gestão de Paulo Maluf na prefeitura.

\section{Município do Rio de Janeiro}

O Rio de Janeiro é o segundo maior município do País, com uma população em torno de 5 milhões de habitantes e a maior rede hospitalar federal e estadual. A extensão desta, sem o conseqüente repasse de recursos para manutenção, resultou no descaso em relação às unidades hospitalares. Em virtude disso, em 1992, os Secretários de Saúde dos municípios ameaçaram devolver as unidades descentralizadas ao Inamps e à Secretaria Estadual de Saúde (SES), visto que os municípios não tinham condições de geri-las. Essa informação, veiculada pela imprensa, não refletiu exatamente o que vinha acontecendo com a descentralização do sistema de saúde, uma vez que, devolvida ou não, de fato a rede estadual e a federal não chegaram a ser incorporadas ao Sistema Municipal de Saúde.

O SUS, na verdade, não foi implantado no Rio de Janeiro, pois no espaço do município foi realizada apenas uma sobreposição das redes municipal, estadual e federal perfeitamente diferenciadas entre si. As unidades, embora repassadas, não receberam o financiamento para suprir as necessidades decorrentes e nem foi implantada uma política salarial para os trabalhadores de saúde. Tanto no caso do governo federal como no do estadual não houve investimento direto para a manutenção da rede, tendo a política estadual de saúde se caracterizado pelo desinteresse das autoridades governamentais.

Cabe fazer uma referência à situação política particular que o estado do Rio vem atravessando desde 1990, que incidiu de maneira determinante na 
implantação de qualquer processo de cunho reformador. A crise generalizada do tecido social e a formação de um governo paralelo vinculado ao narcotráfico no espaço da cidade configuraram um novo tipo de situação de guerra das máfias com ramificações nos altos escalões do governo do estado, Assembléia Legislativa, Judiciário e Polícia Federal.

De um lado, a imposição do terror às populações faveladas, a corrupção e os homicídios dificultaram sobremaneira qualquer forma de organização e participação política da população. De outro, não houve no espaço do estado, enquanto poder público, a capacidade de regular políticas. Essa incapacidade no setor da saúde é expressada na não-intervenção ante situações em que hospitais foram invadidos por narcotraficantes, em que os médicos sofreram ameaças para atender delinqüentes, às quais se soma a corrupção no gerenciamento dos hospitais públicos e a já habitual falta de recursos para a implementação da Reforma Sanitária.

Embora não haja dados oficiais sobre o estado da rede das unidades estaduais, detectam-se informações através das denúncias que se sucederam dia após dia com relação à desativação de leitos, à falta de instrumental e de medicamentos, à precariedade das instalações, assim como à inexistência de condições de atendimento por causa da ausência de médicos, enfermeiros e pessoal auxiliar suficiente.

O Cremerj exerceu importante papel na denúncia e interdição das unidades que não contavam com as mínimas condições de operar. O papel desempenhado por esse órgão será retomado mais adiante. O que importa frisar agora é o caráter inovador ocupado por entidades da sociedade civil em processos político-decisórios - o processo de descentralização democrática da política de saúde -, impondo uma interferência reguladora ao Estado em espaços em que este detinha o monopólio da intervenção. A reação do governador ao desempenho do Cremerj foi afirmar, perante a imprensa, que não permitiria mais a vistoria e a interdição de hospitais por parte do órgão.

A democratização da política, da mesma forma que amplia a arena decisória ao incorporar múltiplos atores e interesses, evidencia e desestabiliza os velhos mecanismos de clientelismo político e de corrupção dominantes na atuação dos políticos ou caudilhos de velho estilo.

De fato, a atuação do Cremerj, através das Comissões de Ética, deixou em evidência a maneira pela qual a Secretaria Estadual de Saúde (não) operava o sistema. A intervenção nos hospitais que se encontravam com sérios problemas 
de funcionamento possibilitou a comprovação da malversação dos recursos públicos em um dos maiores hospitais do estado - o Iaserj -, e também no Instituto Nacional do Câncer (Inca), no Instituto Ary Frauzino e em outros. Por sua vez, as irregularidades nos hospitais não eram um fato isolado, já que correspondiam ao modelo de gestão pública do Secretário Estadual do Governo Brizola.

Dentre as providências tomadas pelas entidades da sociedade é de se ressaltar a ação popular impetrada na Justiça contra o Secretário Estadual de Saúde, por iniciativa do Cremerj, do SinMed e de deputados do PSB e do PT. A apuração na Justiça sustentou-se no superfaturamento das compras de material hospitalar, depois de se comprovar com as notas dos fornecedores uma enorme disparidade de preços, assim como a sangria de recursos utilizada para pagamento de apoio político, favorecimento de empresários da área de saúde e em benefício próprio.

O conhecimento, por parte das entidades da sociedade, da existência de jurisprudência adequada e a utilização de procedimentos judiciais em cada caso comprovado de irregularidade na gestão pública, ao mesmo tempo que colocam uma ameaça virtual para o uso privado de bens públicos, vão gestando uma 'cultura política democrática' no âmago da sociedade. Na medida em que se recorre à via jurídica, abre-se espaço para a prestação de contas por parte das autoridades no exercício do governo e fecha-se o ciclo do livre arbítrio das mesmas e o da ignorância da população.

A reprodução destas experiências vai criando novas modalidades do exercício da democracia política, as quais contribuem para a legitimação e institucionalização de procedimentos democráticos oriundos da ação dos cidadãos. A política se torna, desse modo, próxima da experiência individual, havendo uma reapropriação do político no espaço societário - desde o mais próximo até o mais distante.

Em nossa opinião, tende-se a criar enclaves democráticos, ou, como foi discutido no primeiro capítulo, regimes de democracia parcial nos quais começa a existir uma vivência democrática, a formação de cidadãos junto à institucionalização de procedimentos e práticas no seio da sociedade, mas também do Estado, ainda que em entornos limitados e, talvez, sem condições de adquirir dimensão nacional em um prazo previsível.

A atuação do Ministério da Saúde, a cargo de Jamil Haddad, se fez presente através da formação de uma comissão de emergência para propor so- 
luções à situação crítica das unidades estaduais e federais e dos municípios da Baixada Fluminense.

A Comissão foi presidida pelo secretário-executivo do Ministério da Saúde e ex-presidente do Sindicato dos Médicos. Quanto à secretaria-executiva, esta coube à Fundação Oswaldo Cruz (Fiocruz) e contou também com a participação do Cremerj, SinMed, de parlamentares, secretarias estadual e municipal, dirigentes das federações de moradores do estado. As prioridades ficaram centradas na reativação das unidades desativadas, no Programa de Saúde da Baixada (Pesb) ${ }^{60}$ e na constituição do Conselho Estadual de Saúde.

Exceto a formação do Conselho, de caráter estritamente político, as resoluções emanadas da comissão requeriam a decisão política de serem implementadas e uma injeção considerável de recursos para reabrir as unidades fechadas, contratar o pessoal que assegurasse o seu funcionamento e que permitisse mantê-las posteriormente.

Se considerarmos que nesse ínterim houve importantes mudanças políticas no Ministério da Saúde, como a renúncia do Ministro, novamente nos depararemos com o fato de que o processo de municipalização pode ser gravemente ameaçado de não adquirir a profundidade suficiente que a política de Reforma Sanitária requer para a sua efetivação.

De fato, as condições de operacionalização da política de saúde foram fortemente obstaculizadas pelos retrocessos políticos ocorridos no governo durante o período em análise, mas o processo não foi paralisado em alguns estados e municípios, ainda que em condições adversas, pelo fato de existir neles uma base local-municipal e haver uma decisão política explícita de implementar a Reforma Sanitária.

Em relação ao município do Rio, os serviços de saúde foram mantidos e as instalações recuperadas, oferecendo melhor atendimento à população até 1993. Isso foi feito em 1992 nos maiores hospitais do município, tendo em vista a realização da Conferência Mundial de Ecologia (ECO-92). Os investimentos necessários para recuperar a rede municipal eram recursos federais, já que os hospitais municipais passaram a ser hospitais de referência para atendimento à Conferência. Couberam à Prefeitura o cuidado e a manutenção da rede no cerne do processo de municipalização.

60 O Plano de Saúde da Baixada já foi comentado no segundo capítulo, na parte que se refere ao Movimento Popular em Saúde. 
Uma das principais medidas implementadas pela secretaria, tal como em São Paulo, foi o aumento dos salários dos profissionais de saúde, o que possibilitou a existência de equipes completas de clínicos e de especialistas nos hospitais durante 24 horas.

No caso do município do Rio não houve uma reforma administrativa profunda da Secretaria Municipal de Saúde, ao tempo em que esta se recusou a receber as unidades federais e estaduais. Entretanto, desenvolveu-se uma experiência inovadora, encaminhada pela Secretaria, na gestão de alguns hospitais federais que deveriam ser municipalizados. Consistiu no implemento da cogestão entre o Inamps e o município para a administração dos mesmos. Em termos de resultados, o hospital que manteve por maior tempo a proposta apresentou melhores condições de operação que os outros, o que poderia indicar um caminho a ser seguido na transferência das unidades ao município.

No Rio de Janeiro, embora tenha havido mudança da Prefeitura após as eleições de 1992, com a transferência de poder do PDT para o PMDB, não ocorreram importantes alterações no processo de municipalização da saúde porque o novo prefeito manteve o antigo Secretário Municipal de Saúde no cargo.

As prioridades anunciadas pelo Secretário de Saúde logo após reassumir o cargo foram em relação à prevenção e ao atendimento da saúde da população, assim como aos profissionais de saúde. Quanto à saúde da população, foram criados programas dirigidos à mulher, à gestante e à criança e mantidos os já existentes, de combate ao cólera e à Aids. Com referência aos profissionais de saúde, aumentou-se o número do pessoal de enfermagem e o de seus auxiliares, e os salários dos médicos, embora já se encontrassem no nível de mercado, foram melhorados.

O orçamento municipal destinado à saúde foi mantido no piso da gestão anterior, 11\%, assim como foi sustentado o esforço para captar recursos extraordinários através de empréstimos internacionais, para execução de obras e aquisição de equipamentos, o que já havia dado bons resultados em anos anteriores.

Em relação à participação da população nos Conselhos de Saúde e à reformulação do sistema, não houve um tratamento privilegiado por parte do PDT, partido que administrou desde então a gestão estadual e municipal. Diferentemente do município de São Paulo, o Conselho Municipal de Saúde acabou tendo muito mais uma existência formal do que decisória em relação à política de saúde. Como agravante dessa situação, houve o fato de não ter sido efetiva- 
da uma reforma administrativa e, conseqüentemente, de não existirem Conselhos formalmente reconhecidos nas antigas regiões de saúde nem nas unidades do município.

As avaliações são de difícil realização quanto aos resultados do processo de municipalização, na medida em que o repasse pelas unidades federais foi efetivado sem que a Prefeitura as assumisse sob sua responsabilidade. Considerando o peso substancial da rede estadual e federal no município, não poderíamos afirmar que o processo de municipalização tenha significado uma melhor operacionalização destas.

Ainda que a gestão e a atribuição de recursos da rede municipal de modo geral tenham melhorado, com o decorrer do tempo a sobrecarga desses serviços chegou à saturação pela grande afluência de atendimento à população do Grande Rio - Baixada e Zona Oeste. Como conseqüência da crise dos serviços federais e estaduais no município e estado, as melhorias constatadas na rede municipal não conseguiram ser mantidas, e em 1994 delineou-se novamente uma grande crise de atendimento nos hospitais municipais.

No município do Rio não houve grandes inovações político-administrativas. Assim, por exemplo, o Secretário de Saúde declarou "a impossibilidade de contratação de enfermeiras e auxiliares de enfermagem por ter gasto todas as vagas adjudicadas ao município." ${ }^{61}$ Ao mesmo tempo, recorreu à negociação político-partidária com as instâncias centrais para abrir novas vagas, o que atualizou a modalidade de atuação clientelista, ou 'prefeiturização' da política.

A mesma insuficiência de autonomia na gestão municipal das prefeituras do Rio de Janeiro e de São Paulo se tornam evidentes ao considerarmos questões tais como a contratação dos profissionais necessários para o funcionamento da rede municipal, a indecisão para exonerar o pessoal que não cumpria suas funções e a incapacidade para gerar recursos financeiros próprios que facilitassem o processo de municipalização.

O que essas duas experiências de municipalização revelaram foi uma grande diversidade de alternativas e de modalidades na implementação do processo de descentralização, diversidade essa que se relaciona com a heterogeneidade dos municípios, com a abordagem política e com os encaminhamentos técnicos viabilizados pelas próprias autoridades municipais.

No caso do município do Rio é de se ressaltar, também, uma certa desarticulação do Movimento Popular em Saúde que se foi tornando visível nos 61 Jornal do Cremerj, jan. de 1993. 
últimos anos e que, acreditamos, incidiu fortemente na ausência de uma participação social mais incisiva no processo de municipalização.

\section{Município de Santos}

Santos pode ser considerada uma cidade de médio porte, pois possui 480 mil habitantes. A maioria da população dispõe de água encanada e esgoto. A principal atividade produtiva é o porto, o maior centro de escoamento da produção nacional. Sua população operária é muito elevada e adscrita principalmente às atividades portuárias.

Conta com o maior número de casos de Aids do País, alcançando a cifra de 2.004 notificações entre 1985 e 1990. A mortalidade infantil vem aumentando também, chegando em 1990 a 32 por cada mil nascidos vivos. Tal como nas outras metrópoles do País, houve nas últimas décadas um importante crescimento das doenças ligadas às condições de empobrecimento da população, às quais se agregam as doenças características do desenvolvimento. Neste sentido, os problemas de saúde da população são consideráveis e de solução complexa.

O município alocava $13,5 \%$ do seu orçamento à saúde até novembro de 1992. A partir dessa data, o Secretário Municipal de Saúde foi eleito Prefeito da cidade - devido à gestão desenvolvida anteriormente como Secretário de Saúde - e o gasto dessa área foi elevado para $16 \%$ do orçamento municipal. O governo federal participava somente com $20 \%$ do gasto total em saúde no município, não tendo o governo do estado de São Paulo feito nenhum repasse de recursos entre 1989 e 1994.

A constituição do Conselho Municipal de Saúde, com participação paritária dos usuários e de suas representações, foi uma das primeiras medidas tomadas pelo Secretário Municipal de Saúde, Davi Capistrano, ao assumir o cargo em 1989. Desde sua constituição, todas as atividades da Secretaria passaram a ser submetidas ao Conselho.

A rede pública era composta por 23 policlínicas hierarquizadas e distribuídas em cinco distritos sanitários, que atendiam a uma média de três consultas médicas por habitante a cada ano. Isso fez com que a assistência ambulatorial no município se tornasse compatível com a demanda. Também o número de profissionais foi incrementado, assim como os salários pagos aos mesmos.

A assistência hospitalar passou por momentos de estrangulamento em 1991, já que esta era coberta pela Santa Casa de Santos, que dispunha de 850 leitos e 
era o único hospital conveniado com o SUS. Na época, o Hospital dos Estivadores, que possuía 320 leitos, sendo 21 de UTI, foi fechado por não conseguir pagar as dívidas com funcionários e fornecedores, calculadas em Cr\$200 milhões. A justiça acatou uma ação do Ministério Público, que, baseado no direito constitucional de a população poder ter acesso aos serviços de saúde, propunha a reabertura do hospital de forma que sua gestão passasse para o SUS. Os estivadores conseguiram uma liminar suspendendo a decisão judicial, enquanto o Conselho Municipal de Saúde enfrentou esse sindicato para tentar reabrir o hospital e integrá-lo ao SUS.

Os programas de combate à Aids e de Saúde Mental foram considerados prioridade municipal, com base no Plano de Saúde Municipal. A efetividade desses concentrou, desde então, a atenção de autoridades governamentais, tanto nacionais como internacionais. Foram criados, também, programas especiais, além de um centro de referência em saúde do trabalhador.

O Programa de Combate à Aids consumia 10\% dos recursos em saúde e desenvolveu-se com excelentes resultados. Tanto que passou a ser referência para os programas de controle da Aids em esfera nacional, sendo reproduzido em outras cidades do País e no estrangeiro.

O Programa de Atenção à Saúde Mental realizou-se junto à implementação dos critérios contemplados na Reforma Psiquiátrica, ou seja, os da construção de alternativas assistenciais ao manicômio. $\mathrm{O}$ atendimento psiquiátrico foi basicamente desenvolvido em Núcleos de Assistência Psicossocial e complementado por um Programa de Internação Domiciliar. Depois de uma intervenção feita em um hospital psiquiátrico em 1989, onde havia mais de 500 internos, produziu-se uma verdadeira revolução nos critérios de atendimento aos doentes mentais. Com isso, em 1994 o número de internos desse hospital foi reduzido para 80.

Dentre os programas especiais, cabe ressaltar o Centro da Gestante e Adolescente, o Programa de Atendimento e Internação Domiciliar e o Programa de Atendimento Odontológico. O município contou com um serviço de Vigilância do Recém-Nascido de Risco, inexistente no restante do País, através do qual foram acompanhadas 3.612 crianças no período que vai de 1991 a julho de 1993.

A Secretária Municipal de Saúde eleita em 1992, Aparecida Linhares, manteve inalterada a política implementada na gestão anterior. Sua avaliação sobre o andamento do processo de municipalização do País como um todo, realizada na IX Conferência, revela a concepção política com a qual foi abordado o processo de municipalização em Santos: 
a implantação do SUS não pode descuidar a questão da necessidade de conferir aos municípios um Modelo Assistencial que seja sobriamente compatível com a realidade local (...) um dos preceitos constitucionais trata justamente da Organização Política Administrativa estabelecendo autonomia aos Municípios, Estados e Distrito Federal e, mesmo assim, poucas instâncias tomaram para si esta responsabilidade. (...) É necessária a realização de um movimento político para que o município invista na saúde com recursos próprios. (...) O sucesso de propostas como esta, de municipalização, depende muito da participação intensa das comunidades nas discussões. ${ }^{62}$

A experiência de Santos mostrou, diferentemente de São Paulo e do Rio, o principal papel do município quanto ao incremento da alocação de recursos para o setor e de um diagnóstico apurado, por parte da Secretaria Municipal de Saúde, relativo a problemas de saúde da população a serem priorizados e à maneira de abordá-los. Revelou a necessidade de elaboração de um Plano Reitor de Saúde para o município que compatibilizasse e reorganizasse a infraestrutura de serviços existentes com os objetivos a serem alcançados pelo plano de saúde. Por último, mas destacadamente, enfatizou a necessidade de existência de um Conselho Municipal de Saúde ativo e operante para garantir o controle, por parte da população usuária e de suas representações, de toda e de cada uma das decisões emanadas da Secretaria de Saúde.

A experiência de Santos sugere uma questão interessante, que se refere a como se lidar nessas experiências de municipalização com a multiplicação de atores e de interesses que necessariamente se originam nesses processos de descentralização da política e que apresentam uma dupla face.

Por um lado, a instauração de procedimentos democráticos para lidar com uma pluralidade de interesses promove a criação de vias institucionais de negociação política e, portanto, a institucionalização da política como uma maneira inovadora de resolver conflitos, adjudicar competências e redistribuir poder, como foi o caso do processo de implementação da política de saúde nesse município. Por outro lado, a mesma situação de multiplicação de grupos e interesses pode encaminhar ao uso indiscriminado da negociação política.

Essa modalidade de exercício da política - dentro do âmbito políticopartidário - conduz à diluição das questões conflitivas nas relações entre as forças internas que no partido exercem a autoridade de governo, ou ao desgaste

$\overline{62}$ Anais da IX Conferência Nacional de Saúde. Brasília, 1992. 
ocasionado por um permanente processo de enfrentamento e de acordos posteriores entre o partido governante e a oposição.

Quando à falta de um nível central de condução da política se soma a ausência de diretrizes operacionais em nível local que orientem sua implementação, um diagnóstico claro dos problemas a serem enfrentados e um Plano de Saúde, evidencia-se a recorrência ao fato de a política não conseguir ser resolutiva. Além disso, corre-se o perigo maior de se tornar o seu próprio objeto, na medida em que as preocupações se voltam para a negociação entre as forças conflitantes mais do que para questões específicas relativas à saúde. Acreditamos ser esse um dos dilemas de algumas das prefeituras progressistas que comprometeram consideravelmente a implementação do SUS.

\section{Município de Manaus}

Manaus é um município com 1.300 .000 habitantes, dos quais 98\% reside na zona urbana. É uma população basicamente de origem rural, inserida atualmente na indústria eletrônica, no setor de serviços e no setor de extração da madeira.

De maneira mais acentuada que no eixo centro-sul do País, os níveis de pobreza e de inserção no mercado informal de trabalho de sua população tem crescido enormemente com a queda do ciclo econômico da borracha e a baixa utilização de mão-de-obra no setor industrial eletrônico.

Um dos indicadores recentemente considerado para avaliar os níveis de pobreza é o abastecimento de água e de saneamento básico. No caso específico, pode-se usá-lo para ressaltar esses níveis, pois mesmo em se tratando de cidade capital do estado, somente $10 \%$ da população tem esgoto e $80 \%$ da população urbana tem água pelo sistema formal. Os problemas de saúde da população, correspondentes às suas condições socioeconômicas, são de grande magnitude e extensão. Doenças como tuberculose, raiva humana, hanseníase, pólio, sarampo, leptospirose, febre tifóide, hepatite e, nos últimos anos, o cólera constituem o quadro dramático do município.

A preocupação inicial da Secretaria Municipal de Saúde no período compreendido entre 1989 e 1992 foi a de efetuar um levantamento das condições de saúde da população, as quais, uma vez identificadas, serviram para elaborar o Plano de Saúde e definir as prioridades do município. O saneamento básico municipal recebeu lugar de destaque e foram construídos mais de 370 quilômetros de rede sanitária até o fim da gestão. 
Essa mesma administração promoveu uma ampla reforma administrativa na Secretaria Municipal de Saúde, com a finalidade de efetivar o processo de municipalização. Em Manaus houve uma identidade política das instâncias estadual e municipal com a Reforma Sanitária e com a implementação do processo de descentralização, diferentemente dos casos anteriormente discutidos:

Há integração perfeita entre a Secretaria Estadual, as secretarias municipais, em especial de Manaus, Universidade de Amazonas, Governo Estadual, Governos Municipais e até, como no nosso caso é peculiar, com a zona de fronteira, envolvendo inclusive as instituições vinculadas às Forças Armadas numa discussão global sobre o SUS. ${ }^{63}$

A iniciativa viabilizou-se, de um lado, devido à gravidade da situação de saúde do estado e à ausência de um projeto de saúde alternativo à Reforma Sanitária que permitisse resolver com efetividade a situação de saúde da população. De outro, pela decisão política das autoridades estaduais e municipais e pela articulação das forças sociais capazes de encaminhar e de dar continuidade ao processo por elas iniciado.

A primeira medida encarada pelo Secretário Municipal de Saúde, Evandro Melo, foi a implantação do Conselho de Saúde e do Fundo Municipal de Saúde para o depósito dos recursos da saúde, ambos sob controle da comunidade. O Conselho Municipal foi composto por 24 membros, sendo 12 deles representantes de usuários eleitos direta e democraticamente nas comunidades. Esses membros decidiam todas as questões relacionadas à área da saúde. Pela mesma lei foram criados o Conselho e o Fundo, sendo Manaus a primeira capital brasileira com Fundo implantado e com todos os recursos da saúde, da Prefeitura, do Estado e do governo federal depositados numa mesma conta.

Para que a Secretaria realizasse uma ampla reforma no setor, a cidade foi dividida em seis distritos sanitários. Por sua vez, a Prefeitura dividiu o território do município em núcleos habitacionais formados por 50 mil pessoas, cada um deles contando com uma unidade de saúde com três consultórios médicos e três odontológicos. Cada unidade seria equipada conforme a necessidade da população a ser atendida nos bairros que integravam os núcleos habitacionais. Organizou-se, para cada unidade, um Conselho de Saúde composto por quatro membros, dois representantes de usuários, o diretor e um representante dos funcionários.

63. Entrevista com o Secretário Estadual de Saúde. Proposta, Jornal da Reforma Sanitária, set./out. de 1992. 
O Distrito Sanitário possibilitava qualquer tipo de atendimento médico, pois cada uma dessas zonas tinha um posto e um centro de saúde. Os Conselhos eram compostos por diretores das unidades do distrito e tinham a mesma quantidade tanto de usuários como de diretores. A existência desses distritos permitiu definir as portas de entrada para o sistema de saúde, assim como responsabilizar cada uma das unidades de saúde por uma determinada população, que teria participação ativa através dos seus representantes eleitos nos Conselhos.

A população passou a identificar a unidade de saúde como a unidade que lhe garantiria atenção quando necessitasse. As unidades de saúde, chamadas de portas de entrada, tinham, além dos consultórios médicos e odontológicos, atendimento de emergência 24 horas e encaminhavam os pacientes para níveis de maior complexidade de atendimento.

Toda a rede básica de Manaus contou com 75 unidades na área urbana e de 16 na rural. $\mathrm{O}$ aumento do número de unidades de saúde foi de 21, quando a atual gestão da Prefeitura tomou posse, em 1989, para 54 até agosto de 1992. Agentes de saúde eleitos pela própria comunidade administravam as unidades da zona rural. A Secretaria Municipal visitava os postos uma vez por mês, com equipes formadas por 20 profissionais que desenvolviam desde consultas médicas até palestras sobre prevenção do cólera e outras epidemias e endemias, além de orientações na área social para mais de mil famílias. A rede de serviços de saúde, até meados de 1992, foi ampliada em 86\% e, no fim de 1992, chegou a $100 \%$ em relação ao que havia anteriormente.

Os recursos alocados pela Secretaria Municipal até 1992, correspondentes a 11\% do orçamento municipal, nesse ano passaram para 14\%, cifra que superou o previsto pela Lei Orgânica Municipal. Já o orçamento previsto para 1993 foi de $15 \%$. Os salários dos profissionais de saúde foram elevados pela implementação no município e no estado de um Plano de Carreira, Cargos e Salários para o SUS, que contemplava não só a carreira, mas os pisos mínimos e a capacitação constante do pessoal, implementando-se a formação de pósgraduação para os profissionais da rede e diversos cursos de especialização, em convênio com a Fiocruz e com a Fundação Getúlio Vargas.

Os programas de saúde empreendidos tiveram excelentes resultados e o cólera foi controlado, pois nos últimos cinco meses de 1992 não houve nenhum caso. Para isso foi elaborado um plano de combate ao cólera e o estabelecimento de quais eram as áreas de risco no município e no estado. 
As ações envolveram educação em saúde, informação sobre os riscos da doença, cuidados com a higiene, controle da água e cuidados com alimentos. Foram utilizados agentes de saúde que visitavam casa por casa; distribuiu-se hipoclorito e estabeleceu-se um sistema de vigilância sanitária ao longo de todo o rio. Ao mesmo tempo foram monitoradas todas as diarréias, e, além disso, todas as pessoas com cólera eram identificadas antes de chegarem a Manaus. A cidade foi mapeada e em cada bairro havia um núcleo de pessoas envolvidas nas ações de vigilância sanitária junto aos técnicos e agentes de saúde.

Em relação ao quadro sanitário da população, observa-se que doenças como coqueluche, difteria, pólio e sarampo, que se manifestam nos primeiros anos de vida, tiveram uma queda muito acentuada nesse período. A incidência da pólio foi zerada e reduziram-se também os casos de tuberculose entre 1990 e 1992.

\section{O Município de Manhuaçu}

Trata-se de um município localizado em Minas Gerais, quase divisa com o Espírito Santo, com uma população de 75 mil habitantes, estando 40 mil na área urbana e 35 mil no campo. As principais atividades produtivas são a agricultura do café e a pecuária, nas quais se inscreve a maioria da população recebendo baixa remuneração, o que faz com que a pobreza seja bastante grande, assim como na maioria dos municípios rurais.

Há sérios problemas de saneamento básico, devido ao fato de o esgoto sanitário ser lançado diretamente no Rio Manhuaçu. Essa situação, somada à pobreza, incide fortemente nas condições de saúde da população e, principalmente, na mortalidade infantil.

As principais causas de mortalidade infantil na região são atribuídas às doenças infecciosas e parasitárias, pneumonias e deficiências nutricionais, sendo o coeficiente de mortalidade de 52 para cada mil nascidos vivos. Os problemas de saúde da população adulta são bem diversos: hanseníase, tuberculose, hepatite, parasitárias e deficiências nutricionais. Atropelamentos são também muito freqüentes, em vista de as rodovias federais margearem o município, o que explica que $60 \%$ dos atendimentos em prontos-socorros sejam nos serviços de traumato-ortopedia.

O processo de municipalização iniciado em 1989 e aprofundado pela atual gestão municipal acarretou uma reforma administrativa que dividiu a extensão territorial do município em duas regiões sanitárias, subdivididas em quatro zo- 
nas sanitárias urbanas e quatro rurais. O município contava com uma unidade do Inamps e um posto de saúde do estado, mas ambos foram repassados à Prefeitura, que comprou também um hospital da rede privada.

Como parte do processo de municipalização, foram construídos a Policlínica e o Pronto-Socorro Municipal, que contam com 23 leitos e 51 médicos e prestam cerca de 100 atendimentos diários nas mais diversas especialidades. Também foram implantados 13 postos de saúde, alguns em fase de conclusão - nove deles na área rural e o restante na área urbana - e mais quatro centros de saúde em grandes distritos da área rural.

A maior parte do atendimento e das intervenções de maior complexidade eram feitas no hospital filantrópico, que dispunha de 210 leitos, com o qual a Secretaria Municipal mantinha convênio, administrando e controlando o repasse dos recursos. O sistema dispunha de um hemocentro que registrava, aproximadamente, 200 doações mensais de sangue e um serviço de hemodiálise com 63 pacientes inscritos. O número de profissionais adscritos à rede ampliada foi incrementado consideravelmente. Organizou-se também o Fundo Municipal de Saúde, para o repasse dos recursos federais e estaduais.

O Conselho Municipal de Saúde foi composto por 26 membros, metade deles representando os usuários e a outra metade a Prefeitura, prestadores de serviços e trabalhadores da saúde. Desde a sua formação, apresentou caráter permanente e deliberativo, tendo se constituído na instância máxima para a avaliação e o controle da política de saúde, assim como no tocante à decisão de alocação de recursos.

À atuação do Conselho Municipal somavam-se os Conselhos Zonais e Locais, que desenvolveram um papel central na política de saúde municipal. Assim, por exemplo, o Conselho Local de um dos distritos do município envolvido na preocupação com a proliferação do cólera solicitou uma estação de tratamento de esgotos, já que a rodoviária local recebia diariamente mais de dez mil passageiros de todo o País, tendo sido a mesma construída em oito meses e com um investimento de Cr\$ 1 bilhão.

Através de entrevistas realizadas com representantes dos usuários no Conselho, ${ }^{64}$ constata-se que a mobilização popular e o próprio movimento popular estava organizado e preexistia à implementação do processo de municipalização.

${ }^{64}$ Proposta, Jornal da Reforma Sanitária, 31, 1993. 
Paralelamente, vários programas foram efetivados - Atenção aos Desnutridos e Grupos de Acompanhamento de Diabéticos, Gestantes, Tuberculose e Hanseníase - e a possibilidade de sua realização ocorreu devido à implantação do sistema de informatização e estatísticas do SUS de Manhuaçu para a localização dos doentes. O Programa de Vacinação obteve uma cobertura de 98 a $100 \%$ e todas as crianças atendidas foram cadastradas, o que fez diminuir o número de casos de doenças imunizáveis.

O Departamento de Vigilância Sanitária da Secretaria utilizou procedimentos inovadores e encaminhou à Câmara Municipal um novo Código Sanitário que garantia ao município um efetivo poder fiscalizador e de educação da comunidade. Nessa mesma direção, o atual Secretário de Saúde e Vice-Prefeito, Fernando Bittencourt, enviou um projeto à Câmara estabelecendo gratificações de estímulo aos médicos que aceitassem trabalhar na zona rural, com percentuais variáveis de 30\% a 80\%, já que fixar médicos em tais áreas era uma das grandes dificuldades do município.

\section{Município de Icapuí}

Trata-se de um município rural distante 200 quilômetros de Fortaleza, com uma população estimada, pelo IBGE, em 1989, em 15 mil habitantes. A principal atividade econômica é a pesca, além do artesanato e da agricultura. $\mathrm{O}$ abastecimento de água realiza-se, em $93 \%$ dos casos, através de poço e $66 \%$ da água consumida não recebe tratamento. Somente $7 \%$ do lixo tem coleta pública, ficando a céu aberto $38 \%$ e sendo queimados $38 \%$. O nível de analfabetismo da população é de quase $50 \%$, e da outra metade, apenas $43 \%$ cursam ou concluíram o ensino fundamental.

Em 1991 a Prefeitura iniciou uma campanha de estímulo ao uso de filtros e criou o Sistema Autônomo de Água e Esgoto, que passou a abastecer $20 \%$ da cidade, aumentando também a coleta de lixo. Quanto ao quadro sanitário, as doenças mais comuns eram infecções diarréicas agudas, infecções parasitárias e doenças dermatológicas. O índice de mortalidade infantil foi diminuído para 49,5 por cada 1.000 nascidos vivos, o menor índice de todo o estado, a partir de uma campanha permanente de conscientização da população de como evitar as mortes infantis.

Destinou-se $23 \%$ do orçamento municipal à saúde sem que existisse transferência de recursos do estado para o município. Também foi elaborado um 
plano municipal de saúde que a Secretaria Municipal de Saúde implementou. Cadastraram-se todas as famílias do município, o que proporcionou um diagnóstico de saúde e de condições de vida que serviu de base para a elaboração de programas específicos.

O cadastramento, realizado durante dois meses, envolveu a visita a cada residência por agentes de saúde e por pessoas da comunidade treinadas e supervisionadas por funcionários da Prefeitura. Com base nesse cadastramento, o Plano de Saúde priorizou as ações básicas, o monitoramento das causas de doença e de morte. A partir disso, foram instalados dois centros de saúde que dispunham de consultórios médicos e odontológicos, farmácia, sala para reidratação oral e quatro postos de saúde nas seis áreas ou distritos sanitários em que foi dividido o município.

A pedido dos pacientes foram utilizadas redes em lugar de camas nas salas de observação dos centros de saúde. Em todas as unidades implantou-se um prontuário familiar, o que permitiu vincular as famílias aos distritos sanitários, assim como o acompanhamento das mesmas. Há a pretensão de se construir, ainda, um hospital com horário integral no município.

O Conselho Municipal de Saúde foi composto por cinco representantes das instituições prestadoras, cinco profissionais de saúde e 25 representantes das comunidades e de outras categorias profissionais. Constituiu-se outro importante fórum de decisões, as reuniões mensais de funcionários da Secretaria de Saúde. Os profissionais de saúde, que vinham tendo seus salários reajustados mensalmente, receberam isonomia e novas formas de reajustes a partir da elaboração do Plano de Cargos e Salários, desde 1991.

Destacamos, para a análise comparativa, algumas das variáveis contempladas na abordagem dos municípios selecionados, tais como: o tamanho dos municípios, o encaminhamento de reformas administrativas e/ou reorganização dos serviços, os recursos financeiros aplicados pelas secretarias municipais, a implantação ou não dos Conselhos, o grau de autonomia municipal, a elaboração do quadro sanitário da população e do Plano de Saúde Municipal, a existência/extensão da rede estadual e federal, aumento do número de leitos, incorporação de melhorias salariais dos profissionais de saúde. Os quadros a seguir apresentam uma síntese analítica das variáveis contempladas nos municípios selecionados. 
Quadro 13 (Parte I) - Análise comparativa dos municípios estudados

\begin{tabular}{|lllll|}
\hline Municípios & Tamanho & $\begin{array}{l}\text { Reforma Administrativa/ } \\
\text { Reorgarnização dos } \\
\text { Serviços }\end{array}$ & $\begin{array}{l}\text { Recursos } \\
\text { Financeiros }\left(^{*}\right)\end{array}$ & $\begin{array}{l}\text { Implantação dos } \\
\text { Conselhos }\end{array}$ \\
\hline São Paulo & grande & $\operatorname{sim}$ & + & $\operatorname{sim}$ \\
Rio de Janeiro & grande & não & + & não \\
Santos & médio & $\operatorname{sim}$ & +++ & $\operatorname{sim}$ \\
Manaus & médio & $\operatorname{sim}$ & +++ & $\operatorname{sim}$ \\
Manhuaçu & pequeno & $\operatorname{sim}$ & +++ & $\operatorname{sim}$ \\
Icapuí & pequeno & $\operatorname{sim}$ & +++ & $\operatorname{sim}$ \\
\hline
\end{tabular}

(*) Classificamos a variável Recursos Financeiros em termos de porcentagem do orçamento municipal destinado à saúde:

(+) até $10 \%$

(++) $10 \%-14 \%$

$(+++)$ mais de $14 \%$

\section{Quadro 13 (Parte II) - Análise comparativa dos municípios estudados}

\begin{tabular}{|c|c|c|c|c|c|c|}
\hline Municípios & $\begin{array}{l}\text { Grau de } \\
\text { Autonomia } \\
\text { Municipal }(*)\end{array}$ & $\begin{array}{l}\text { Quadro } \\
\text { Sanitário/ } \\
\text { Plano de } \\
\text { Saúde } \\
\text { Municipal }\end{array}$ & $\begin{array}{l}\text { Existência/ } \\
\text { Extensão de } \\
\text { Rede Estadual } \\
\text { e Federal (**) }\end{array}$ & $\begin{array}{l}\text { Aumento } \\
\text { do Número } \\
\text { de Leitos }\end{array}$ & $\begin{array}{l}\text { Melhorias } \\
\text { Salariais } \\
\text { Profissionais } \\
\text { de Saúde }\end{array}$ & $\begin{array}{l}\text { Resultados } \\
(* * *)\end{array}$ \\
\hline São Paulo & + & não & + & não & $\operatorname{sim}$ & + \\
\hline R. Janeiro & + & não & +++ & não & $\operatorname{sim}$ & + \\
\hline Santos & +++ & $\operatorname{sim}$ & + & $\operatorname{sim}$ & $\operatorname{sim}$ & +++ \\
\hline Manaus & + & $\operatorname{sim}$ & - & $\operatorname{sim}$ & $\operatorname{sim}$ & +++ \\
\hline Manhuaçu & +++ & $\operatorname{sim}$ & - & $\operatorname{sim}$ & $\operatorname{sim}$ & +++ \\
\hline Icapuí & +++ & $\operatorname{sim}$ & - & $\operatorname{sim}$ & $\operatorname{sim}$ & +++ \\
\hline
\end{tabular}

(*) A variável Autonomia Municipal foi considerada em termos da capacidade do município incorporar inovações de caráter político-administrativo e a estratificamos com base na seguinte escala de valores:
$(-) \quad$ nenhuma
$(+) \quad$ pouca
$(++) \quad$ mediana
$(+++) \quad$ considerável 
(**) A variável Existência/Extensão da Rede Estadual e Federal foi classificada pelos seguintes valores:

(-) não tem

(+) escassa

$(++) \quad$ mediana

$(+++) \quad$ grande

$\left.{ }^{(* *}\right)$ A variável Resultados foi classificada de acordo com os avanços político-administrativos do processo de municipalização e lhe atribuímos os seguintes valores:

(+) escassos

$(++)$ medianos

$(+++)$ importantes

O quadro evidencia a relação inversa entre o tamanho dos municípios e os resultados alcançados. A dimensão dos mesmos constitui, efetivamente, dificuldade na implementação da municipalização, associada à extensão das redes estadual e federal sem que exista uma legislação terminada sobre a matéria nem condução política do poder central.

Muito embora os obstáculos à municipalização sejam conexos às dificuldades no nível central do sistema, também se conectam com as realidades locais, a que se somam a falta, às vezes, de clareza e de definição quanto ao projeto sanitário e/ou ausência de um plano de saúde a ser operacionalizado pelas prefeituras locais.

No caso dos municípios do Rio e São Paulo, há resultados próximos, apesar dos projetos políticos serem completamente diferentes. Acreditamos ser as situações encontradas nos dois municípios adversas à municipalização, por várias razões: pela incidência local muito grande do poder central - Inamps; pela deterioração em que se encontravam as unidades de saúde; pela própria relação de forças desfavorável à implementação da Reforma, dada a concentração do setor privado hospitalar nesses municípios e pelo estado de desmobilização política que atravessava o Movimento Social em Saúde, especialmente no Rio de Janeiro. A outra questão foi o grau de improvisação política e técnica das prefeituras.

Em Santos e Manaus, o panorama inicial em termos do projeto político a decisão de implementar a Reforma Sanitária - é semelhante, diferindo os resultados dos alcançados pelo Rio e por São Paulo. Isso por serem municípios menores, com reduzida incidência do nível federal no setor saúde - hospitais e postos do Inamps - e onde, pelos motivos expostos, se faz necessário aumen- 
tar o número de leitos do setor público. Nestes casos foram incorporados, ao plano de saúde municipal, um diagnóstico preciso e apurado das condições de saúde da população, a definição das prioridades e sua operacionalização.

Nos municípios de pequeno porte, se observam menores condicionamentos políticos, técnicos e de infra-estrutura de serviços na implementação do processo de municipalização nos casos de prefeituras e secretarias afinadas com o projeto da Reforma Sanitária. O fato de não contar com rede federal e/ou estadual, e às vezes nem municipal de serviços de saúde, exige do município destinar parcela considerável do orçamento municipal à saúde, mas facilita a incorporação de procedimentos inovadores na gestão do sistema.

A formação de uma rede própria, nesses pequenos municípios, não implica serviços de alta complexidade e tecnologia. Como foi visto, quando preexistem no município, ainda que pertencentes ao setor filantrópico ou privado, o número de serviços não excede o de um hospital de nível terciário, como no caso de Manhuaçu. De fato, administrar e controlar um número exíguo de convênios com os serviços credenciados ou gerir um hospital do nível federal ou estadual simplifica enormemente a administração do sistema.

Devido à menor complexidade com que se apresentam as questões nesses municípios, é necessariamente menor o nível de imbricamento político, técnico e administrativo, se bem que o diagnóstico da situação de saúde da população, assim como o plano a ser implementado, constituam requisitos básicos.

A capacidade de inovação política por parte dos governos locais nos municípios pequenos fica menos subordinada à relação das forças sociais e políticas atuantes no espaço local do que no caso dos municípios médios e grandes, dado o caráter quase familiar das relações sociais em pequenas localidades rurais. O que pode haver é a potencialização de projetos, conforme o grau de enfrentamento das forças políticas locais.

O incremento dos salários dos profissionais de saúde e a elevação do número de profissionais adscritos à rede parece ser condição prioritária do processo de municipalização. Ainda que com gradações e modos diversos de atender à questão, esses são pontos nodais sem os quais dificilmente existe Reforma, também representando um empecilho afeto à própria prática médica.

Os Conselhos de Saúde, ainda que essenciais à efetivação da política, merecem discussão em separado, retomada na seção deste capítulo referente aos movimentos sociais em saúde. De qualquer maneira, os Conselhos de Saúde tendem a ter uma atuação mais homogênea e harmônica nos diversos 
níveis de implementação, quando há no município um movimento popular organizado e certo grau de mobilização social em torno das condições de vida e de saúde da população e o incentivo à participação social na gestão municipal, por parte das autoridades.

Finalmente, cabe destacar o grau em que a autonomia da gestão municipal e os recursos financeiros aplicados pelo município no setor saúde se relacionam diretamente com os resultados do processo de municipalização, mesmo quando, caso do Rio de Janeiro, a relação é alterada por variáveis intervenientes, como observado no quadro anterior.

Quanto maior o grau de autonomia e aplicação de recursos ao sistema, melhores resultados. Ainda no que concerne aos recursos, o repasse automático federal e estadual a uma única conta foi facilitado nos municípios que possuíam o Fundo Municipal de Saúde. Dos casos selecionados, ocorreu em Santos, Manaus e Manhuaçu, mas na maioria dos municípios brasileiros os Fundos de Saúde não foram criados.

Um dos pontos relevantes do processo de municipalização é a própria atribuição local da autonomia da gestão municipal. Estamos nos referindo à atribuição própria, porque ainda que a autonomia dos municípios seja contemplada pela Constituição de 1988, falta ainda, como a outros tópicos da Constituição, ${ }^{65}$ a regulamentação através de leis ordinárias das atribuições dos diferentes poderes. Nessa situação, cabe às instâncias descentralizadas criar jurisprudência sempre que colabore para viabilizar a implementação do SUS.

A autonomia municipal constitui peça-chave para a efetivação dos princípios da Reforma Sanitária, requerendo, então, maior ortodoxia no cumprimento da Constituição e na formação de uma institucionalidade democrática em nível local. A inovação de procedimentos político-administrativos, diferenciando as experiências locais, origina também conseqüências não desejadas, a fragmentação da política de saúde em grande diversidade de experiências isoladas, sem margem a uma homogeneização da política de saúde no conjunto do País.

A fragmentação poderia ser resultado da autonomia municipal, mas, na verdade, a ausência de um nível de condução central da política e de um processo de descentralização que considere o nível estadual contribui como fator de atomização das experiências de municipalização.

$\overline{65}$ Vide no financiamento da saúde a modalidade de repasse dos recursos. 
Qualquer que seja a razão, parece claro - a posteriori da análise dos municípios aqui considerados - que o processo de descentralização poderia ser uma 'condição de possibilidade' para o exercício da cidadania, colaborando para o rompimento de barreiras entre cidadãos e Estado no exercício da democracia, ao deslocar o poder de decisão da órbita exclusiva do Estado.

Tal condição contribuiria para aproximar a democracia política de uma maior eqüidade na distribuição de benefícios de saúde entre as camadas menos favorecidas da população, mas não só isso. Constitui-se, principalmente, em processo educativo, na medida em que as transferências de cotas de poder nos níveis locais do exercício da política exigem do cidadão maior conhecimento e informação que o habilitem a ter um papel decisório nos Conselhos Locais de Saúde. 


\section{Os Conselhos de Saúde}

Uma vez que o sistema de saúde foi objeto de profundas reformas, importa detectar em que grau os entraves a essa política foram, em parte, conseqüência da ação e/ou comportamento do movimento social organizado. A análise da trajetória do Movimento Popular em Saúde - formação, ascensão e declínio - permitiu algumas inferências relativas ao papel e projeção que os movimentos populares em saúde se reservaram diante das políticas de saúde.

Um dos pontos aparentemente cruciais é o próprio modo de atuação desses movimentos, a partir da busca da 'autonomia' tanto na mobilização popular quanto no distanciamento das instâncias estatais de saúde, não obstante estas previssem a participação popular. A rejeição à participação do movimento popular nos Conselhos de Saúde fez com que se perdesse a capacidade de influenciar a política de maneira efetiva.

Observa-se que, ao mesmo tempo em que a mobilização é estruturante no momento em que acontece, fragiliza o movimento porque depende de fatores externos, como graves crises do setor saúde, sejam de cunho epidemiológico ou de atendimento rotineiro.

Tal tipo de atuação, sustentada na autonomia e evitando a relação com o Estado, acaba eximindo-o de atuar nos Conselhos e acentua a rejeição existente nesses movimentos à estruturação e articulação de modalidades da atividade política, a não ser as oriundas exclusivamente da mobilização. A tendência a certa institucionalização e o reconhecimento de formas alternativas à mobilização poderiam gerar nos movimentos um investimento de inovação política, estruturas próprias e autônomas de incidência mais decidida nos rumos da política.

Com efeito, o tipo de atuação desses movimentos no período de consolidação da democracia e da implementação da política de saúde, obstaculizou a 
co-responsabilidade no processo de efetivação da mesma. Mais, impediu-os de neutralizar o surgimento de tendências altamente corporativas no Movimento Médico, acabando estas por ocupar o espaço abandonado pelos movimentos populares nos Conselhos de Saúde. A mobilização acabou por converter-se em empecilho, pois não houve readequação da estratégia na luta política do Movimento Popular em Saúde.

Isso é causa suficiente para rever a atuação dos Movimentos Populares em Saúde no âmbito específico dos Conselhos de Saúde, instância esta de caráter deliberativo da política de saúde, na qual os usuários e suas entidades e movimentos representativos contavam com $50 \%$ da composição dos Conselhos, por regulamentação da Lei Orgânica da Saúde.

\section{Formação e Funcionamento dos Conselhos de Saúde}

Os Conselhos de Saúde são, como regulamenta a Constituição Nacional, o principal órgão de participação da sociedade na definição do sistema e dos serviços de saúde nas esferas nacional, estadual e municipal. Sua ingerência prevê a formulação do Plano de Saúde adequado à operacionalização do SUS, a definição e aplicação orçamentária do setor, a reorganização administrativa, o gerenciamento da rede, a alocação e remuneração dos profissionais de saúde e o próprio modelo assistencial.

De um total de 27 unidades federadas do País, os Conselhos foram legalmente constituídos em 14. ${ }^{66}$ Juridicamente, sem funcionarem, existiam em 11 estados, e sem definição jurídica em apenas dois. Sua formação não foi impulsionada nem exigida pela sociedade ou por entidades organizadas na maioria dos estados brasileiros. Originaram-se via de regra por iniciativa dos técnicos das secretarias estaduais de saúde, alinhados às forças reformistas. Em geral, sua origem é localizável nas diversas instâncias da esfera governamental. Assim, por exemplo, no Rio de Janeiro a iniciativa foi do Legislativo.

Em apenas oito estados houve participação considerável de setores da sociedade na formação dos Conselhos e, em dois, essa participação foi decisiva. Dependendo também do estado, naqueles em que se deu a participação

${ }_{66}$ Os dados sobre os Conselhos foram obtidos da pesquisa "Avaliação do Funcionamento dos Conselhos Estaduais e Municipais de Saúde", desenvolvida pelas seguintes entidades: Ibam; IMS/Uerj; Nesc/CE; Nescon/UFMG; Ness/BA. Relatório Nacional, versão preliminar, agosto de 1993, Ministério da Saúde-Conselho Nacional de Saúde. 
popular verificaram-se diferenças e/ou conflitos entre as representações populares e/ou usuários propriamente ditos.

Apesar de a lei determinar o caráter deliberativo dos Conselhos, estes acabaram tendo papel meramente consultivo. Os avanços para se tornar um canal de denúncias da sociedade que facilitasse o pleno acesso da população às informações de saúde, à participação dos conselhos nas unidades de serviço e à articulação destes com o Conselho Nacional de Saúde e com os Conselhos Municipais de Saúde variaram de estado para estado, dependendo do interesse dos governadores em impulsionar ou não a formação dos mesmos.

Poucos estados ampliaram as atribuições e funções dos Conselhos de Saúde. A composição dos Conselhos Estaduais não foi paritária, como previsto pela Lei Orgânica da Saúde (8.080/90) e pela Resolução 33/93, Os dados de conjunto do País indicam uma bancada maior de representantes de prestadores (350) que de usuários (312). Os dados correspondem à análise dos 24 Conselhos estaduais - Maranhão e Santa Catarina não os instalaram legalmente, e Sergipe não foi abrangido pela mencionada pesquisa.

Entre os prestadores foram incluídos os representantes do Poder Executivo - federal, estadual, municipal - do Legislativo, os profissionais de saúde, os prestadores stricto sensu e a comunidade acadêmica. No total dos estados, os representantes dos três níveis de governo somavam 161 membros, com o executivo estadual tendo o maior número de membros (97). Os representantes do poder Legislativo eram em número de oito; os dos profissionais de saúde, de 106; os dos prestadores do setor público e privado somavam 56 e os de intelectuais e acadêmicos do setor, 19 .

A bancada dos usuários abarcava movimentos sociais e comunitários com representação de 123 membros que se apresentavam de forma bastante diversificada, com inúmeros segmentos, sendo a de maior presença a das associações de moradores, seguida do Movimento Popular em Saúde (10). Os trabalhadores e centrais sindicais somavam 96 representantes; os empresários de todos os setores da economia estavam representados por 36 membros; os portadores de doenças contavam com 40 representantes e os organismos religiosos com 17.

As bancadas de trabalhadores e profissionais de saúde, somadas, constituíam a maioria dos membros dos Conselhos Estaduais de Saúde. A representação dos prestadores era composta por 56 membros, dos quais 37 representantes do setor privado filantrópico e lucrativo. 
Acerca de tais dados, merece ser mencionado que a composição dos Conselhos parece indicar tendência à representação de caráter corporativo, antes de mais nada. Outro aspecto refere-se ao peso dos prestadores privados em relação aos públicos, embora estes últimos pudessem estar representados também no Executivo e no Legislativo, vários deles eram proprietários de clínicas e hospitais. Não ficou claro se havia representantes de prestadores públicos diretores de hospitais públicos - e, se assim fosse, em que proporção tinham assento no Executivo e no Legislativo.

O mandato dos Conselhos variava conforme os estados. Em 50\% deles a duração era de dois anos, enquanto nos demais de um a quatro anos. Em Goiás, Amazonas, Mato Grosso do Sul e Paraná, havia coincidência do mandato dos representantes do Conselho com os do governo. Quanto às reuniões ordinárias, eram realizadas uma vez ao mês, e as extraordinárias convocadas pelo presidente ou por $50 \%$ dos membros. Somente em alguns estados a pauta de reunião era distribuída com antecedência. As decisões eram tomadas por votação nominal e a deliberação por maioria simples. ${ }^{67}$

Poucos estados dispunham de dotação orçamentária para o funcionamento dos Conselhos. O fato é indicativo de um papel menor na decisão das políticas, já que nenhum órgão de governo carece de dotação. Ainda que os Conselhos fossem órgãos criados pela política de saúde para que a sociedade. Desse modo, seus membros não tiveram remuneração. O que de fato aconteceu, principalmente na esfera municipal, foi que os representantes de movimentos e de usuários nos Conselhos não tinham, às vezes, condições de comparecer às reuniões por não poder custear seu próprio transporte. ${ }^{68}$ Trata-se de aspecto extremamente problemático pois a carência dos meios pecuniários, somada à nãodifusão dos resultados das deliberações dessa instância política, além da nãodivulgação das informações necessárias sobre o sistema de atendimento, tornou inócua a sua atuação.

A representatividade foi bastante desigual. Predominou a iniciativa do Estado sobre a da sociedade, com algumas variações nos estados em que as entidades da sociedade participaram da criação dos conselhos. A indicação dos conselheiros, em quase todos os Estados, foi decidida pelas suas respectivas entidades, sendo nomeados pelo governador.

\footnotetext{
67 Em relação à dinâmica de funcionamento, a pesquisa considerada analisou 12 estados, já que os restantes não se encontravam ainda em pleno funcionamento e os que funcionam eram muito recentes, o que dificultam a avaliação.

68 Ver Cohn, Elias \& Jacobi (1993).
} 
Em dois estados o Poder Legislativo foi inserido na bancada dos usuários - Pernambuco e Amazonas -, enquanto nos demais ele integrou a bancada do Poder Executivo. A inclusão dos representantes do Poder Legislativo na bancada dos usuários significa uma completa inversão da idéia original dos Conselhos, que visava o controle social da população na implementação da política.

De fato, a solução mais razoável é incluí-la na bancada do Poder Executivo, independentemente de que partidos tivessem maior peso no Legislativo. Cabe evidenciarmos isso, já que tem sido questão constante das agendas das secretarias municipais e estaduais de saúde.

Faz-se necessário inclusive acrescentar que em estados onde não há movimento social organizado e onde os representantes do Legislativo têm posições próximas à Reforma Sanitária, representar os movimentos e usuários expressa um comportamento de cunho paternalista em relação à população e pouco condizente com os procedimentos democráticos.

Observa-se que a maioria dos Conselhos não operam nem como um espaço institucional de canalização das demandas da população por melhores condições de atendimento e cuidados de saúde no município, nem como um espaço de denúncia dos problemas de saúde local. Tampouco há visibilidade, para a população, sobre a existência e a finalidade dos conselhos, nem ações planejadas destes para a ocupação de espaços nos meios de comunicação de massa que sirvam à difusão, existência e alcance dos conselhos de saúde.

A falta de orçamento próprio inviabiliza o encaminhamento de desdobramentos imprescindíveis ao desenvolvimento da ação dos conselhos. A articulação dos conselhos estaduais com o conselho nacional e com os conselhos municipais é, outrossim, mais ou menos intensa, dependendo do estado. Em alguns destes, há ainda uma articulação com universidades e organizações nãogovernamentais através de consultas, capacitação de recursos humanos, elaboração de planos de saúde e nas conferências estaduais.

Quanto às condições administrativas, financeiras e técnicas de funcionamento e decisão, ficou evidenciada a relação de dependência dos Conselhos com as Secretarias Estaduais.

A respeito dessas constatações ressaltamos que, ainda que os usuários participem pouco dos Conselhos, a existência destes gera um impacto político devido ao conhecimento que a população tem da existência dos mesmos e à influência que estes podem ter no sistema de saúde, visando obter melhor atendimento para a população. 
Neste sentido, a existência dos Conselhos é um espaço difusor de práticas políticas alternativas, colaborando para que alguns autores no campo da ciência política denominam contextual effects (Schmitter, 1985). No caso, seriam resultados inesperados não a um nível agregado, mas quanto a uma mudança na percepção que os indivíduos ou a população possa adquirir em relação a uma determinada política. Dito de outra forma, o 'acesso' à política de saúde tornase algo próximo dos usuários, na medida em que existem órgãos deliberativos da política sobre os quais estes têm ingerência direta.

A definição de prioridades em saúde não foi, na prática, assumida pelos Conselhos enquanto a formalização da incorporação de reclamações e sugestões dos usuários para a elaboração do Plano Estadual não foi implantada.

Dos municípios existentes no País, apenas 68\% foram cadastrados pela pesquisa. ${ }^{69}$ Destes municípios, $62 \%$ constituíram legalmente o Conselho Municipal de Saúde a partir de 1991. Nos pequenos municípios, a existência dos Conselhos é menos freqüente e quando estes existem funcionam de maneira regular apenas na metade dos municípios.

Nos municípios capitais dos 26 estados da federação, as secretarias municipais de saúde representaram os principais agentes para a criação dos mesmos, entre os anos 1990-1991.

\section{Os Conselhos de Saúde nas Capitais e Municípios}

A composição dos Conselhos Municipais das capitais foi formada por parte dos usuários, sobretudo por representantes dos movimentos sociais, num total de 168 membros. Nesse grupo, os representantes do Movimento Popular em Saúde (27) e, em segundo lugar, as associações de moradores (15). Além dos movimentos comunitários havia a bancada das entidades de trabalhadores (66), nas quais predominavam membros das centrais sindicais e entidades de trabalhadores em saúde.

Por parte dos prestadores, os representantes do Poder Executivo eram 126, sendo 81 da esfera municipal, 23 da federal e 18 da estadual. Os profissionais de saúde contavam com 102 representantes das áreas médicas, de enfermagem, de entidades de trabalhadores de saúde, estando os demais distribuídos por outras categorias.

\footnotetext{
69 Avaliação do Funcionamento dos Conselhos Estaduais e Municipais de Saúde (agosto de 1993).
} 
Ainda da parte dos prestadores, além dos representantes do Poder Executivo e dos profissionais de saúde, havia os prestadores stricto sensu, que somavam 49, sendo 11 da área pública, 11 dos filantrópicos e 15 dos privados. Por fim, a comunidade acadêmica possuía 17 cadeiras nos Conselhos. Novamente o Poder Legislativo tomava assento como Estado e como usuário em Macapá, Manaus e Boa Vista.

Os conselheiros eram indicados pelas entidades e nomeados pelo prefeito. O tempo de duração do mandato era também, em alguns municípios, atrelado à gestão municipal. A dotação orçamentária, preconizada pela legislação federal, só era atendido por dois municípios, o do Rio de Janeiro e o de Palmas.

A organização interna dos conselhos era composto de Plenária, de Secretaria Executiva e de presidente. O do município de São Paulo apresentou peculiaridades, visto que substituiu a Plenária por Colegiado Pleno e constituiu Comissões Interdisciplinares permanentes para discussão de assuntos setoriais da saúde, além de uma Comissão Executiva para a apreciação de denúncias e de demandas com caráter deliberativo.

Os municípios de Goiânia, Recife e Belo Horizonte constituíram Mesas Diretoras, enquanto Rio de Janeiro e Porto Alegre tinham núcleos de coordenação. De modo geral as reuniões realizavam-se mensalmente e a tomada de decisões, na maioria dos casos, ocorria nas Plenárias e Colegiados, através de votação nominal aberta, e quando necessário, secreta.

Os resultados explicitados ajudam a complementar a análise do processo de municipalização, ao mesmo tempo que a interpretar seu caráter. Da mesma forma que na análise do processo de municipalização, no caso dos Conselhos podese constatar que a descentralização da política de saúde tem acontecido de maneira incompleta. O processo avançou no nível municipal da política, mas a profundidade e o alcance da municipalízação do setor saúde diferem entre os municípios. No nível estadual têm sido imensas as dificuldades para que se assuma o processo de descentralização e a formação dos Conselhos de Saúde.

Pode-se afirmar que existiram grandes empecilhos por parte das Secretarias Estaduais de Saúde para a efetivação do SUS. Isso diz respeito à falta de entrosamento dos governos estaduais com a Reforma Sanitária e ao despreparo e inadequação gerencial, administrativa e orçamentária das secretarias estaduais para assumir a descentralização.

A situação é mais bem contornada no nível local/municipal, devido ao fato de a estrutura do sistema de saúde - a rede de serviços - possuir menor 
complexidade, à exceção dos municípios que constituem as grandes cidadescapitais do País, onde a rede municipal convive com as redes federal e estadual. De modo geral, a efetividade dos Conselhos relaciona-se à pressão exercida pelos usuários, pelos movimentos sociais organizados e profissionais de saúde e à maior proximidade da população com as autoridades locais.

Seja como for, o processo de municipalização, ainda que tenha tido enorme difusão política, uma vez que a questão da municipalização passou a ter papel principal na implementação da política pública, não teve o efeito almejado em relação às transferências de poder para os níveis locais e particularmente para a população.

Essa situação se explica pelo fato de a política se localizar exclusivamente no nível municipal, sem uma definição de atribuições e obrigações das esferas federal e estadual e sem o repasse correspondente dos recursos. Porém, principalmente, devido ao fato de os Conselhos não terem sido criados "de baixo para cima", o que fez com que ficassem depreciados e dependessem da vontade política dos governadores e prefeitos para incentivá-los ou não.

Ao se comparar os Conselhos municipais com os Conselhos estaduais, verifica-se que os primeiros têm sido bem mais atuantes, tendo a população exercido algum controle em termos de financiamento, administração e gestão das unidades de saúde. Essa atuação difere bastante de município para município, mas tem ocorrido de forma continuada, ainda que o início da década de 90 corresponda a um momento político caracterizado pelo declínio na ação dos movimentos sociais em saúde e, especialmente, do movimento popular e associações de moradores.

\section{Os Conselhos de Saúde e a Participação Cidadã}

A problemática em jogo é a passagem de uma postura de oposição para a de participante ativo, situação que o alinha às forças governamentais e o coloca como co-responsável das decisões a serem implementadas. Mas para a continuidade da luta das forças populares, isso tem sido muito mais um fator de enfraquecimento e desunião que propriamente um estímulo.

Há uma observação que se repete em todo documento impresso dos movimentos populares "as coisas só acontecem quando a gente começa a lutar". No entanto, a impressão ao fim de um levantamento, e pela observação da atuação desses movimentos, é de que não se acredita e se desconhece 'do que' e 'de quanto' é possível mudar através da participação e do controle social. 
Revisando panfletos e publicações fidedignas do movimento popular, constata-se que existe difusão a respeito dos Conselhos e sua finalidade, ou seja: "através destes a população exerceria o direito de controlar, fiscalizar, formular e participar do planejamento e execução das políticas de saúde". ${ }^{70}$

Trata-se de um processo que se encontra em um momento inicial e que sofre fortes resistências das diversas instâncias do Executivo, prestadores privados etc., expressas em obstáculos à viabilização de um funcionamento mais fluido dos Conselhos, não os considerando órgãos deliberativos ou não lhes atribuindo dotação orçamentária. É uma situação dúbia: o Poder Executivo não lhes reconhece o caráter decisório e o Movimento Social em Saúde e os usuários lhe retiram o crédito, dificultando que os Conselhos alcancem uma posição de destaque na transformação da política de saúde.

$\mathrm{O}$ discurso do próprio movimento, aliás, parece cair num vazio. $\mathrm{O}$ usufruto da saúde e o atendimento à doença, como algo resultante ou relacionado à participação e à conseqüente atividade nos Conselhos, parece não ser entendida como questão decisiva para melhorar o atendimento.

Assim, a importante bancada de representantes de movimentos e usuários não tem revertido num papel mais operativo e resolutivo dos conselhos de saúde, situação notória nos conselhos estaduais: de uma parte, estes não se constituíram em elemento dinamizador da mobilização popular, como foi à época o processo constituinte. De outra, o período transcorrido na década de 90 caracterizou-se pela fragmentação dos movimentos sociais em geral, com a conseqüente paralisação da ação coletiva dos movimentos populares em saúde.

No âmago do Movimento Popular em Saúde produziu-se um impasse, com uma divisão ideológica que neutralizou a política no âmbito de sua implementação. Isso ocorreu a partir do esvaziamento do potencial de participação das entidades autônomas, que, ao estarem divididas e fragmentadas, criaram uma armadilha para a não-participação.

Se participar leva à cooptação, não participar ou se abster de fazê-lo a evitaria, mas inviabilizaria a política. A não-participação colaboraria com dois tipos de conseqüências: abrir brecha para o corporativismo médico e facilitar a cooptação de agrupamentos ou da própria população não-articulada no Movimento Popular em Saúde.

$\overline{70}$ Se Liga no Sinal, 3(12), jul./ago. 1993 (Informativo do Cepel, Rio de Janeiro). 
A alternativa participação/não-participação, na qual o Movimento Popular em Saúde se colocou, o submete a uma lógica que lhe é alheia, conduzindo-o ao dilema do prisioneiro, expressa como paralisia decisória (Elster, 1989).

Definitivamente o desafio é a criação de formas inovadoras de atuação política capazes de inaugurar uma outra lógica que abra as comportas a idéias não tão polarizadas e inibidoras, tais como Estado/não-Estado, participar/ não-participar, ser cooptado/não ser cooptado etc. Polarizações ideológicas às quais o movimento se prende e que estão profundamente relacionadas a uma visão de Estado que o impede de se perceber 'fora de', ainda que o discurso seja o da autonomia do movimento em relação ao Estado.

O espaço que os movimentos e usuários não preenchem nos Conselhos de Saúde passa a ser ocupado pelas entidades médicas novamente atuantes no plano político, reivindicando a implementação do SUS e, no plano corporativo, exigindo isonomia salarial, plano de cargos e salários e melhores condições de trabalho e de atendimento no setor público e privado.

O que se deduz da prática do movimento popular durante o período início da década de 90 é a inexistência de sinais de recuperação no processo de declínio observado desde o fim dos anos 80. O engajamento político do movimento, que excepcionalmente reapareceu na oportunidade da IX Conferência, voltou a se esvair ante as dificuldades de implementação da política de saúde nas suas instâncias - agora descentralizadas -, assim como os Conselhos de Saúde - órgão de participação social na política de saúde.

O próprio Estado contribuiu para que sua importância fosse minimizada, ao não reconhecê-los. Em nossa maneira de ver, trata-se de um direcionamento não deliberado, de um acontecer que vai ocupando o espaço que o movimento deixa vago e que se expressa através de formas individuais e solidárias de resistência à dor e até à própria morte, enquanto estratégias para superar a sofrida experiência de empobrecer e adoecer dessas populações carentes, crescente nos últimos anos.

Às vezes ocorrem expressões ou manifestações de caráter mais coletivo, tais como formação de hortas comunitárias ou de grupos de acompanhamento de doentes. Entretanto, mais freqüentemente acontecem de maneira individual, quando os próprios moradores procuram se capacitar como agentes de saúde comunitários ou doam tempo à colaboração em atividades revertidas para a saúde da comunidade - como a desinfecção de valas etc. -, orientadas por impulsos solidários e relacionadas de maneira imediata a situações de sobrevivência. 
Muitas dessas experiências retomam práticas anteriores das comunidades eclesiais de base da década de 60, recuperando ideais religiosos de comunhão vicinal. Esse tipo de prática remete à discussão do papel dos sujeitos na política, na medida em que reivindica e valoriza os procedimentos com os quais a cultura e a experiência popular contam para enfrentar a vida. Revela o reconhecimento, extremamente valioso, de um acervo pessoal do qual os indivíduos lançam mão, como alternativa não-médica para enfrentar a doença e o sofrimento.

Com tudo isso, evidencia-se a perda dos espaços criados pela Reforma Sanitária para a efetivação da política de saúde, pois embora o movimento participe dos Conselhos não os tem como próprios e decisórios para alcançar o sistema de saúde almejado pelas populações carentes.

Contudo, torna-se evidente que existe também um retrocesso do próprio movimento em sua articulação e institucionalização. De fato, a institucionalização torna-se imprescindível para que se constituam interlocutores políticos legítimos e reconhecidos pelo Poder Executivo e pela sociedade organizada - sindicatos, partidos políticos, entidades médicas, organizações religiosas e outras.

A não-institucionalização do movimento leva à não-maioridade do mesmo, sendo continuamente desconsiderado, tutelado ou protegido por forças mais solidamente constituídas. Se essas políticas acabam acontecendo como resultado do curso natural - a procura da sobrevivência -, como a saída possível em face do descaso do Estado, são, também, limitadoras ao não acarretarem a capacidade de interferir no sistema de saúde.

Os condicionamentos políticos, sociais e econômicos a que essas populações necessitadas estão submetidas parecem remeter a certas condições de maturidade organizativa e, portanto, a políticas que não conseguem se cristalizar internamente no movimento e que são reiteradamente alternadas com a desinstitucionalização do mesmo. Simultaneamente, na mesma medida em que o movimento abandona o espaço de interferência na política de saúde, reproduz a perpetuação das condições de existência dessas populações.

Em suma, se o movimento não ocupa os possíveis espaços políticos abertos, acaba reproduzindo o lugar político que lhe foi atribuído. Ao mesmo tempo, outras forças organizadas se apropriam - no caso analisado, as entidades médicas - desses canais de interferência nas decisões políticas. De fato, no momento em que as entidades médicas retomaram a atuação política, passaram a exercer uma função tutelar em relação ao usuário do sistema público de saúde, através do papel destacado nos Conselhos de Saúde e nas políticas de saúde dirigidas às camadas pobres da população. 


\section{Conclusão}

A escolha teórica dos movimentos sociais em saúde no processo de reformulação e de implementação das políticas de saúde teve a pretensão de deslocar o foco de análise da política de saúde, enquanto política social, da esfera do Estado como lugar privilegiado para se pensar a política pública.

Situados nessa perspectiva, penetramos na formação, nos comportamentos políticos e na atuação desses movimentos no transcurso de um momento da história política do País em que as tensões e contradições sociais e políticas exacerbadas pelo regime autoritário, no que se refere às relações Estado/sociedade, buscaram vazão através da transição à democracia. Foi precisamente nessa passagem e na redefinição de áreas de política social, como a da saúde, que se localizaram os novos atores sociais e os protagonistas da cena democrática, confundindo-se com o próprio processo de instauração da democracia.

Tal decisão levou a que se trabalhasse com três focos de análise simultaneamente e a deslocar ou priorizar temporariamente um sobre os outros: os movimentos sociais em saúde, a construção da democracia e a política de saúde.

Num enquadramento estritamente teórico do nosso múltiplo objeto, nos parece necessário estabelecer algumas considerações. Os movimentos sociais em saúde fazem parte de movimentos sociais e com eles compartilham as novas formas de associativismo relacionadas à formação de identidades coletivas. Estas são sustentadas em laços de solidariedade originados das condições de vida de populações carentes - seja em moradia, transporte, saúde, infraestrutura urbana, educação etc. - ou em situações que afetam as condições e as modalidades de vida da classe média - meio ambiente, violência urbana, discriminação de minorias, pauperização de setores profissionais etc. 
Neste sentido, os movimentos sociais em saúde, embora não constituindo fenômeno restrito ou específico do setor da saúde, têm elemento distintivo que os caracteriza, que é o fato de se originarem numa área específica de política social, situação que não se verificou com a mesma especificidade e alcance em nenhum outro setor da política pública.

A área de atuação desses movimentos restringiu-se às questões relativas à saúde da população e às políticas de saúde. No entanto, a discussão política ultrapassou essa esfera, questionando as relações entre Estado e movimento, a política governamental e a autonomia e a institucionalização dos mesmos.

Constata-se que os movimentos sociais em saúde contribuíram para a ampliação do exercício da política, levando ao interior do Estado uma problemática que dele estava ausente, ao mesmo tempo que aproximou das decisões relativas à política de saúde tradicionalmente reservadas ao Estado os destinatários da mesma. Dessa forma, o movimento social exerceu papel protagonista no encurtamento da distância entre a esfera privada e a ordem pública.

O enfoque teórico pelo qual nos aproximamos da compreensão do Movimento Social em Saúde incorporou as diversas concepções relativas à ação coletiva e à formação de identidades políticas que ajudaram a explicar as motivações que levaram atores coletivos e individuais a se disporem ou não a agir coletivamente na reformulação das políticas de saúde, dentro do contexto maior da transição à democracia.

A idéia defendida em relação ao conceito de movimento social implica uma novidade talvez sutil, mas nem por isso menos importante, na medida em que envolve a noção de comportamento coletivo. Dito de outra maneira, essa categoria refere-se, por um lado, a uma modalidade particular de associação caracterizada pela fluidez organizativa, pela falta de institucionalização e, conseqüentemente, pela ausência de regras formais que definam hierarquias e vínculos entre os seus membros.

Por outro lado, diz respeito ao modo como viabiliza demandas de teor político-reivindicativo, através da mobilização ou da ação coletiva, na qual a disposição para a ação é fortemente marcada pela presença do 'coletivo'. Isso complementa o conceito, visto que ajuda a identificar os movimentos sociais pelo comportamento político que os agrupamentos sociais desenvolvem.

Enfoques teóricos diversos recebem articulação plena, se olhados da perspectiva da definição do nosso objeto de pesquisa. Analisar as políticas sociais da perspectiva dos atores sociais envolvidos nas decisões políticas e como destina- 
tários das mesmas levaram a reconstruir um campo teórico que se expandisse para além das teorias do Estado e do papel das políticas sociais nessa esfera. Ao mesmo tempo que não podíamos deixar de incluir este campo de pensamento, éramos obrigados a deslocar o eixo de reflexão da política social para o âmbito das sociedades.

Recriar uma perspectiva teórica na relação entre atores e política no contexto histórico delimitado pelo nosso objeto de pesquisa, tornou figura principal o que era pano de fundo, fazendo com que o processo de estabelecimento de regime democrático na abordagem da transição à democracia ganhasse papel fundamental na análise da relação entre os movimentos sociais em saúde e as políticas de saúde.

Assim, discutimos a democracia nos seus aspectos constitutivos e em suas transformações impreteríveis nos pares de relações esfera pública/privada, indivíduo/sociedade, eqüidade/justiça social, como condição necessária para o estabelecimento de regime democrático capaz de assentar as bases de novo padrão das relações Estado/sociedade, no qual as políticas sociais e em especial as de saúde - por lidar com a vida e a morte -, em sociedades profundamente desiguais, exercem papel fundamental para a constituição da ordem democrática.

A idéia de democracia assinalada ao longo deste livro sustenta-se na de constituição de sujeitos democráticos capazes de reproduzir comportamentos e ações políticas que levem em conta a existência do 'outro'. Trata-se da promoção de democracias com extensiva participação social.

Por outro lado, em situações de imensas desigualdades socioeconômicas, das quais o Brasil é um exemplo, num mundo que se aproxima cada vez mais da privação e da injustiça social, verifica-se ilusório ignorar o papel que o Estado tem a desempenhar na fundação de novo modelo de democracia que vá além da instalação de um sistema político democrático.

Neste sentido, as políticas sociais, e dentre essas, particularmente, a Reforma Sanitária, constituem elementos centrais na democratização do Estado, tendo em vista que veiculam a participação social em área tradicionalmente restrita - ou seja, a da implementação de políticas - e promovem a alocação e redistribuição progressiva de benefícios que contribuem para o estabelecimento da justiça social progressiva.

De fato, ao discutirmos a Reforma Sanitária na moldura do processo de formação e implementação de políticas sociais, ao mesmo tempo que sinalizávamos os constraints estruturais relacionados ao próprio processo de acumula- 
ção no Estado capitalista, enfatizávamos a presença de 'nível singular' de análise das políticas sociais, onde aspectos de inovação política ampliaram o espaço social e a luta política na arena estatal, tanto nos procedimentos burocráticoadministrativos como nas relações de força societária que a implementação da política foi capaz de desencadear.

No entanto, a questão de importância fundamental, em nossa opinião, é o papel singular que adquirem as políticas sociais devido a este ser, precisamente, campo propício à incorporação de inovações políticas e que, no período estudado, mostrou-se ameaçado pelas políticas de ajuste econômico das décadas recentes, o que retraiu as políticas sociais a sua manifestação mínima.

O papel regulatório do Estado na relação com o mercado e o setor privado, assim como sua intervenção enquanto promotor do desenvolvimento econômico e da justiça social, requer Estado forte - contrariamente à idéia neoliberal do Estado mínimo - e lhe impõe novas atribuições e exigências. Dentre estas, o desmonte e o redimensionamento da máquina estatal e a criação de centros de decisão política em que tenham assento e representação os diversos interesses sociais em jogo, na sociedade, relacionados a políticas específicas. E implica, fundamentalmente, sensibilizar o Estado para experiências locais de gestão, especialmente nas áreas de política social, de modo que a democracia se confunda cada vez mais com a eqüidade social e que as mudanças se configurem em objeto de reflexão, discussão e avaliação contínuas, principalmente no que concerne a resultados e à efetividade obtidos através das mudanças implementadas.

O conceito de cidadania é central à perspectiva que nos interessa no processo de constituição de um regime democrático, quando os processos de reformas abrangentes das políticas sociais constituem a condição de possibilidade para o estabelecimento de sociedade mais justa e eqüitativa. Razão pela qual, ao discutir a cidadania, procuramos denotar o sentido e a compreensão embutidos na concepção teórica que lhe deu origem e apontar as contradições que o conceito denunciou a partir do desenvolvimento histórico, já não do conceito, mas da cidadania no mundo moderno.

Concluímos, assim, que a eqüidade - resultante do percurso histórico da consecução de direitos de cidadania, como conquista da sociedade ou mais especificamente da classe operária nas sociais-democracias dos países de capitalismo avançado - está estreitamente relacionada à idéia de justiça social enquanto valor ético-moral impreterível ao estabelecimento da democracia. A constru- 
ção da democracia refere-se à construção do que se tem chamado de "democracia radical" (Mouffe, 1992:238):

A distinção privado (liberdade individual)/público (res publica) tal como a separação indivíduo/cidadão não correspondem a esferas separadas. Não é possível dizer onde termina minha obrigação como cidadão e onde começa a minha liberdade como indivíduo. Estas duas identidades existem em permanente tensão e não podem ser reconciliadas. Mas esta é precisamente a tensão entre liberdade e igualdade que caracteriza a democracia moderna. A essência deste regime e de quaisquer tentativas de trazer a harmonia completa, ou seja, compreendê-la como democracia 'verdadeira' só levaria a sua destruição. Esta é a razão pela qual o projeto de democracia radical e plural reconhece a impossibilidade da compreensão de democracia plena e a realização última da comunidade política. Seu objetivo é usar recursos simbólicos da tradição democrática liberal para lutar pelo aprofundamento da revolução democrática, sabendo que este é processo sem fim. Minha tese é que a cidadania ideal poderia contribuir enormemente para a extensão dos princípios de liberdade e igualdade. Unindo os direitos ideais e o pluralismo com as idéias do espírito público e o engajamento político-ético, uma nova concepção democrática moderna da cidadania poderia restaurar a dignidade da política e prover o veículo para a construção de uma hegemonia democrática radical.

A concepção de democracia passa, assim, a denotar um processo no qual o sentido não é dado pela adscrição e pela procura de modelo acabado, seja doutrina econômica a implantar ou proposta de sociedade. Trata-se de condição necessária ou, dito de outra maneira, da amplitude com que a democracia é capaz de viabilizar valores ético-morais, isto é: eqüidade e justiça social, enquanto bastiões da dignidade humana; respeito à pluralidade cultural, étnica, religiosa, preferências sexuais, de gênero etc. e a liberdade em todas as manifestações do-que-fazer humano. Porém, os obstáculos a uma democracia que incorpore tais valores e comportamentos políticos decorrentes dos mesmos - um regime democrático societário - afiguram-se intransponíveis.

O conceito de "regimes de democratização parcial" (Schmitter, 1991a) foi de grande importância para pensarmos - considerando as dificuldades expostas anteriormente - a constituição da democracia como estabelecimento de estruturas e comportamentos democráticos em áreas restritas de políticas, nas quais uma particular configuração sociopolítica as faz portadoras de maleabilidade 
que as habilita a veicular transformações num conjunto de instituições mais sensíveis à participação e à discussão societária.

Neste sentido, a constituição da democracia é compreendida como um processo político de partes em movimento, um mix de regimes parciais de democratização (Schmitter, 1991a) que atualizam interiormente as dificuldades de mudanças mais homogêneas e unívocas, e conseqüentemente a democracia como processo político, porque incompleto, em permanente transformação.

A formação de regimes de democratização parcial sinaliza, portanto, um caminho de aproximações sucessivas em que recortes não completamente estruturados compõem um mosaico inacabado e em permanente movimento. Definitivamente, por trás da idéia da formação de 'regimes de democratização parcial', o que se tem é uma abordagem metodológica que renuncia à idéia de totalidade para ancorar na indeterminação, resgatando uma direcionalidade progressiva.

O setor da saúde, particularmente a Reforma Sanitária brasileira, tem se constituído num regime de democratização parcial caracterizado pelo ressurgimento da sociedade civil e pelo nascimento dos movimentos sociais em saúde que desempenharam papel inestimável na política de saúde, até então praticamente confinada ao espaço exclusivo do Estado.

A análise do Movimento Social em Saúde na sua relação com a política nacional de saúde mostrou a origem dos movimentos sociais relacionada à acepção de 'cidadania' que os processos de democratização trouxeram para o centro da cena política. Já a trajetória desses movimentos religou-se às alternativas que os protagonistas sociais imprimiram ao processo de transformação da política de saúde nas diversas esferas implicadas.

O Movimento Social em Saúde, nas duas vertentes analisadas e na relação com o processo de formulação da política de saúde, atravessou fases extremamente diversas. A ação coletiva foi, num crescendo, marcada pela identidade coletiva alcançada pelo movimento, mas também caracterizou-se por momentos de clara estagnação, nos quais as dificuldades se evidenciaram, principalmente ao ter que optar diante de modalidades mais institucionalizadas no exercício da política.

O período da transição à democracia, marcado pela oposição ao regime militar com amplos setores da sociedade engajados, foi propício à formação do Movimento Popular em Saúde. De fato, se originou sob o calor da discussão crítica das condições de saúde das populações marginais nas grandes metrópoles. Esse período de formação iniciado em finais da década de 70 foi 
influenciado pelas comunidades eclesiais de base - experiências de organização popular desenvolvidas pela Igreja com as populações carentes - e pelas experiências de medicina comunitária, como política de saúde alternativa ao sistema de saúde do regime autoritário. Teve como difusores intelectuais e profissionais de saúde engajados numa prática político-partidária.

Ainda que as políticas de saúde tenham se erigido no eixo que marcou a atuação do movimento, a relação deste com as políticas de saúde foi caracterizada pela dinâmica interna do próprio movimento. Questões relativas à proposta político-organizativa - a autonomia diante do Estado, a institucionalização do movimento e a relação com os partidos políticos - foram adquirindo significado decisivo, o que se depreende da trajetória desses movimentos ante as políticas de saúde.

O que diferenciou o momento de estruturação do movimento foram as tentativas para conseguir articulação nacional e a oposição às políticas de saúde do regime militar, que excluíram as populações carentes do atendimento e dos demais cuidados de saúde, ao favorecerem o setor privado às custas do setor público. A proposta alternativa articulada pelo movimento foi a da medicina comunitária, a ponto de os encontros nacionais do Movimento Popular em Saúde, nos primeiros anos, denominarem-se 'encontros de medicina comunitária'.

A fase de ascensão do movimento coincidiria com mudanças substantivas no processo político de democratização, quando a ênfase recaiu na definição de propostas políticas que, diferentemente da época autoritária, estimulassem os setores da sociedade excluídos no regime precedente à participação social e econômica.

Sob esse aspecto, a proposta da Reforma Sanitária foi tomando forma até alcançar o ponto de maior definição na VIII Conferência Nacional de Saúde. O Movimento Popular em Saúde amadureceu neste contexto tanto no que se refere à proposta - localizada na medicina comunitária para abranger o Sistema Nacional de Saúde - quanto na articulação política do movimento, com a criação de federações estaduais e confederações nacionais de bairros e favelas.

Foi um segundo momento em que o processo definitório da reformulação do sistema de saúde se confundia com a existência mesma do Movimento Popular em Saúde. As interferências relativas à problemática interna do movimento, mencionadas antes, eram menos notórias, embora já se evidenciassem diferenças a respeito da estatização do sistema de saúde e da autonomia do movimento em relação àquela. 
Por último, a fase de declínio que se caracterizou mais pelo agravamento da discussão política interna que por definições claras do movimento em relação à implementação da Reforma Sanitária. Esta fase pode ser definida como a das resistências e dificuldades que o movimento enfrentava diante de um processo de institucionalização que lhe permitisse, talvez, atuação mais decisória na política de saúde, através de Conselhos Municipais, Estaduais e Nacional.

Algumas reflexões ou inquietações retomam o enfoque teórico - 'pela mão' da trajetória do movimento - agora no que concerne à dinâmica da relação entre atores e políticas. Quando se constituem os atores em sujeito e quando deixam de sê-lo? Como consegue, ou não, esse tipo de movimento transcender suas limitações para se situar no plano da definição da política?

A dificuldade que o Movimento Popular em Saúde exprime em sua trajetória é a de se assumir como 'sujeito autoconstruído' em lugar de 'em oposição a'. Essa passagem é, afinal, evolução em relação ao Estado. Ao longo do tempo, o lugar ocupado reiteradamente pelo Estado acaba se configurando em limite estreito e constrangedor na percepção de 'si mesmo', e conseqüentemente, na sua operacionalidade política.

Isso significa que, não estando resolvido o dilema a respeito de 'si mesmo', este impede a projeção no âmbito político, em atuação duradoura, ainda que chegue a ser sujeito político ou sujeito na política diante de situações de crise, de maneira, quando muito, apenas esporádica.

Esse auto-limitar-se da atuação faz com que o processo a encaminhe à perda progressiva na capacidade de decisão estratégica, ao mesmo tempo em que desemboca no objetivo rejeitado. Seu contorno está configurado de 'fora para dentro', não à maneira da autonomia tal como compreendida pelo movimento, mas segundo a dimensão com que o Estado vai avultando na atuação do movimento e nas distorções do discurso ideológico.

Assim, o discurso torna-se realidade enquanto impossibilidade de construção de espaço próprio. Em tal sentido, não é o Estado que coopta o movimento, mas é o temor à cooptação que acaba impondo ao movimento, enquanto este pretende se definir como organização independente, a disjuntiva entre ser organização sob a luz do Estado ou desaparecer definitivamente.

De alguma maneira a 'profecia auto-cumprida' presente no imaginário desses movimentos é intrinsecamente estabelecida pela própria dinâmica constitutiva dos mesmos, até adquirir um peso decisivo no fiel da balança: a ameaça de 
cooptação deixa de ser virtual e se torna fantasmagórica realidade ou simplesmente realidade.

Já o Movimento Médico e sua atuação face às políticas de saúde apresentaram uma problemática interna e questões bem diversas das detectadas no movimento popular. Em primeiro lugar, a denominação 'movimento' esbarra na particular modalidade de articulação e organização que, no Brasil, os profissionais médicos têm se dado, na prática, desde a regulamentação da medicina como profissão. Com efeito, o Movimento Médico é formado por diversas entidades. Várias delas, originadas no início do século XX, caracterizam-se por alto grau de institucionalização e presença nos vários níveis em que se desenvolve a vida do profissional médico.

A mobilização por reivindicações laborais e a oposição às políticas de saúde dominantes no regime militar levaram os médicos, do final da década de 70 até meados dos anos 80 , a agir coletivamente sem que a atuação da categoria estivesse atrelada às instituições médicas. Criou-se um Movimento Médico que, sem desconhecer a existência das entidades médicas, não as reconhecia como condutoras efetivas da classe. A categoria agia supra-instituições médicas, muitas destas tendo passado até mesmo por intervenções militares. A liderança efetiva da categoria foi assumida pelo Movimento de Renovação Médica, originado de uma chapa eleitoral formada para disputar as eleições no Sindicato dos Médicos.

A condição de possibilidade para que os médicos agissem e se constituíssem em movimento com identidade coletiva relacionava-se às peculiaridades da corporação médica, sustentadas mais do que numa estrutura hierárquica, na força que o ideário da profissão médica tem para com seus praticantes (Caro, 1969).

Desse modo, a atuação do Movimento Médico caracterizou-se por forte resistência às políticas de saúde do regime militar e pela disputa de um papel principal na elaboração, junto a outros integrantes do Movimento Social em Saúde, de uma proposta de reformulação do sistema, o que culminou na proposta nacional de Reforma Sanitária por ocasião da VIII Conferência Nacional de Saúde.

A constituição do Movimento Médico, característica principal da atuação da categoria na década, mudou substantivamente no final dos anos 80. Em pleno processo de democratização do País - sem a oposição aos militares como traço de união do movimento e uma vez regulamentada a Reforma Sanitária na Constituição Nacional de 1988 -, os médicos passaram a ser representados pelas instituições médicas. Dentre estas, adquiriu papel central o Sindi- 
cato dos Médicos - em defesa dos interesses econômico-corporativos dos mesmos - e o Conselho de Medicina - que tentava preservar o papel político dos médicos na defesa dos princípios da Reforma Sanitária.

É necessário salientar as diferenças que permearam a categoria médica relacionadas às transformações no mercado de trabalho, as quais se refletiram numa atuação política focalizada nas múltiplas formas de representação dos interesses médicos, segundo a particular inserção destes no mercado de trabalho. Nessa contingência, o movimento social se fraturou e a defesa da implementação da Reforma Sanitária e dos princípios que lhe deram origem cedeu lugar às diferenças evidenciadas internamente na categoria e expressas na representação dos interesses da corporação médica.

No que diz respeito à categoria médica, em face das políticas de saúde houve o gradual abandono dos princípios da Reforma Sanitária e os médicos manifestaram, por meio de sucessivas e intermináveis greves, o inconformismo com a situação salarial e com as condições de trabalho, eixos principais da atuação da corporação na década de 90 .

A articulação do Movimento Popular em Saúde foi difusa de modo geral, o que se explica pela especificidade desse tipo de movimento. Dispõe de uma organização flexível, pouco formalizada institucionalmente. A mobilização por demandas de saúde ante o Estado é que desempenha papel principal em sua constituição e permanência no cenário. Contudo, o Movimento Popular em Saúde e o Movimento Médico chegaram a ter uma dinâmica de atuação bem articulada em tomo das grandes questões do setor.

Por algum tempo - na primeira fase e até meados da segunda -, o processo de reformulação do setor, que culminaria com a Reforma Sanitária na VIII Conferência Nacional de Saúde, assim como com a formação da Plenária Nacional de Entidades de Saúde para influenciar o processo constituinte e a regulamentação da Constituição Nacional, contou com o trabalho conjunto do movimento popular e do Movimento Médico no apoio à incorporação da Reforma Sanitária na Constituição.

As dificuldades entre ambos os movimentos se evidenciaram menos com relação à política que em relação a interesses divergentes entre usuários e médicos centrados, de um lado, nas necessidades de atendimento da população e, de outro, nas greves médicas por melhores salários e condições de trabalho, que desde 1989, de maneira ininterrupta, levaram a uma pronunciada crise de atendimento do setor público (situação mais notável, aliás, nos estados com grande 
rede federal e estadual e os que ofereciam as piores condições de remuneração e de infra-estrutura hospitalar).

As greves no setor público, já bastante depreciado pelo descaso dos governos federal e estadual, reforçariam o desmonte deste, o que afetaria profundamente os usuários do sistema - populações de baixa renda em geral e que não dispunha de nenhuma outra opção de atendimento. A situação gerou enfrentamentos, tendo a população manifestado-se contra os médicos em diversas oportunidades. ${ }^{71}$

A atuação dos médicos foi de encontro aos interesses dos usuários. Mas a resistência do Movimento Popular em Saúde em se institucionalizar e a ter papel mais decisivo na política deixaram desprotegidos os usuários, abrindo caminho para o corporativismo médico.

Cabem aqui algumas reflexões a respeito do peso ou incidência de cada uma das seguintes questões na atuação do Movimento Social em Saúde, em face da implementação da Reforma Sanitária: a articulação política entre os movimentos, a modalidade de atuação e de organização interna e a própria política de saúde, tal como implementada na esfera do governo.

Em primeiro lugar, os fatores externos ao movimento - a particular modalidade governamental na implementação da Reforma Sanitária, explicável pelas diferenças político-ideológicas do governo com a Reforma - tiveram grande peso no retrocesso político do Movimento Social em Saúde. Em segundo lugar, o que se depreende do tratamento da questão é que os mesmos fatores externos não foram determinantes no comportamento que esses movimentos desenvolveram, comportamento este que respondeu à própria dinâmica interna dos mesmos.

O modo como os movimentos reagiram aos empecilhos opostos pelo governo à Reforma Sanitária obedeceram, no caso do movimento popular, à particular modalidade de atuação e às resistências do movimento a ter participação mais incisiva na política de saúde através dos Conselhos de Saúde, o que facilitou a rendição à atuação corporativa dos médicos.

Fatores externos e internos ao movimento interagiram num campo extremamente conflituoso - o das políticas de saúde -, com forte conteúdo de reforma, num contexto de democratização do País extremamente frágil, no

71 Vide conflito sobre o Hospital da Posse, mencionado no capítulo 5. 
que se referia às transformações substanciais necessárias à concretização do estabelecimento de um regime democrático.

As dificuldades vieram após o processo de implementação da Reforma, marcada pelo retrocesso político do Movimento Social em Saúde, que se caracterizou - caso do movimento popular - pelas divergências políticas internas que paralisaram sua atuação, pelas mudanças que afetaram a categoria médica e pela ausência do papel de liderança política que desempenhara o Movimento Sanitário nos anos 80 .

Enquanto o movimento popular se debatia no dilema de participar e ser cooptado pelo Estado ou abster-se e evitar a cooptação, o papel potencial que entidades autônomas poderiam exercer para forçar a participação social nos Conselhos de Saúde foi inviabilizado pelos próprios movimentos. A situação, ao contribuir para neutralizar a questão embutida na concepção da Reforma Sanitária, é que, paradoxalmente, favoreceu o corporativismo médico e facilitou, efetivamente, o caminho para a cooptação de representantes de usuários nos Conselhos de Saúde.

No que se refere ao papel que o Estado deveria preservar para dar prosseguimento à política, os empecilhos colocados pelo governo foram decisivos para impedir avanços substantivos do processo reformador no setor saúde. Os avanços que a Constituição de 1988 incorporou à própria noção de saúde e ao sistema que viria a possibilitar a distribuição mais eqüitativa da saúde passou por tentativas diversas, marcadas pelo desconhecimento da legislação constitucional e pela modificação das leis, substituídas por decretos do Executivo que contradiziam a letra, o escrito e o espírito da Constituição.

Foi o tratamento que recebeu inicialmente a Lei Orgânica da Saúde, ao ser vetada pelo Presidente da República expressamente nos tópicos referentes às Conferências Nacionais e aos Conselhos, à formulação de Plano de Carreiras e Salários, à transferência automática dos recursos e à restruturação do Ministério de Saúde, com a extinção e descentralização do Inamps, Sucam e FSESP.

De qualquer maneira, se o governo cedeu nesse ponto específico, na operacionalização das medidas constitucionais, conseguiu sistematicamente desrespeitar o estabelecido por lei, como observado na questão do repasse dos recursos a estados e municípios, que continuaram com as mesmas dificuldades.

Deduzimos do exame do processo que este tem avançado nas linhas de menor resistência política - o repasse dos serviços - enquanto o 'núcleo duro' da Reforma correspondente ao financiamento do sistema de saúde não sofreu 
as alterações necessárias para a implementação da política a ser efetivada, com o que se obteve o estabelecimento apenas de mudanças de caráter administrativo ou reorganizativo dos serviços no SUS.

Embora o processo de descentralização, com a atuação do Inamps e de outros órgãos centralizadores da política, tenha acontecido mais pelo incentivo do Movimento Social em Saúde, particularmente a partir da realização da IX Conferência Nacional, consistiu sempre de medidas circunstanciais sobre o desgaste do governo, pela força ocasional alcançada nesses momentos pelo Movimento Social em Saúde, sem que as medidas revertessem em duradouras melhorias quer do funcionamento do sistema quer da administração, de maior bem-estar relativo à saúde para a população mais necessitada.

Seja como for, o que o processo de descentralização evidenciou nos municípios analisados foi que a existência de algumas precondições - governo municipal consubstanciado com a proposta, a existência de um projeto de saúde municipal elaborado a partir do quadro sanitário da população, o aumento dos recursos destinados ao setor, o aumento dos salários dos profissionais de saúde - facilitarou indiscutivelmente a implementação da Reforma Sanitária no nível local.

Neste sentido, importantes transformações foram operadas no setor saúde, ainda que localizadas mais no plano político que em resultados concretos, considerados estes como melhoras palpáveis nas condições de saúde da população. Mas o setor tem-se tornado, como se pode observar em algumas das experiências de municipalização da política, mais sensível à participação da população, mais transparente na gestão do sistema e mais plural na atuação dos diversos atores que o compõem, ainda que seja difícil esperar transformações mais substanciais no setor.

A Reforma Sanitária, resultado de um movimento originariamente societário de oposição ao regime militar, cujas lideranças provinham de partidos políticos da esquerda, foi uma proposta que extrapolou o setor saúde. É indiscutível que a Reforma Sanitária brasileira constituiu-se num paradigma político da noção de Reforma no campo das políticas sociais e, conseqüentemente, num laboratório privilegiado para a análise da viabilidade na implementação de transformações nas instituições estatais e a relação entre reforma(s) e democracia.

Dado o atual estágio e as dificuldades na consolidação do regime democrático, os impulsos reformadores no setor saúde e a capacidade de viabilizálos colaboram para a constituição de um regime de democratização parcial 
num setor de políticas específico e em um determinado momento, fazendo, reitere-se, aportes relevantes para o (re)estabelecimento de um regime democrático no Brasil.

A afirmação remete à idéia de a consolidação da democracia considerar-se mais que um regime, um mix de regimes parciais articulando e governando um conjunto de instituições cuja consolidação não acontece simultaneamente. No marco do processo de consolidação da democracia, a Reforma Sanitária constituiu-se um regime de democratização parcial, apesar das limitações antepostas pelo governo a sua implementação.

A análise do processo de implementação da política reformadora é extremamente esclarecedora a respeito das questões teóricas discutidas no capítulo inicial. Se observarmos até onde houve avanços no processo de implementação da Reforma, veremos sustentar-se de maneira conclusiva a idéia de que os limites de política de reformas substantivas no setor não foram dados por limitações intrínsecas à democracia, mas pelo caráter que a democracia adquire em determinados processos nacionais e de acordo com circunstâncias históricas, sociais e políticas.

Neste sentido, o governo vitorioso primeiras eleições livres para Presidente da República, após o longo regime autoritário, não teve por meta dar substância social à democracia política nascente. Manteve-se, isso sim, muito longe de promover o estabelecimento de um regime de embasamento democrático.

Cabe reiterar que a relevância da afirmação anterior se apóia no significado dado à concepção do que seja o estabelecimento de regime democrático relacionado à reprodução da própria democracia enquanto maneira de envolver o conjunto atuante das relações sociais e políticas e capaz de atualizar as diferenças, além de definir saídas à base de consenso construído em processo discursivo (Habermas, 1984), ou, dito de outra forma, pela aceitação da existência do 'outro' social e/ou político no campo relacional específico.

O conceito em que 'alavancamos' a compreensão da Reforma Sanitária - o da formação de 'regimes de democratização parcial' - remete ao estabelecimento de regras e comportamentos democráticos num campo determinado de políticas e instituições. A capacidade de expandir a reprodução da democracia por aproximações sucessivas, com o intuito de conquistar um regime democrático tanto na sociedade quanto na ordem política, ajudou a pensar a formulação e a implementação das políticas de saúde como processo em permanente transfor- 
mação. A partir disso constatamos o quão profundas foram as mudanças, sobretudo na formulação e na definição da política alcançada, na medida em que problemas da mesma intensidade e alcance, em nível governamental e dos movimentos, dificultaram o andamento progressivo da Reforma Sanitária.

Assim, a análise da participação social, através da atuação, organização e articulação dos movimentos sociais em saúde nos sucessivos momentos diferenciados da trajetória da Reforma Sanitária, evidencia que 'regimes de democratização parcial' são viáveis quando se leva em consideração o estágio em que os atores sociais, com inserções diversas na política, se constituem a 'partir de' e se expressam 'para' viabilizar ou dificultar o andamento de dada política.

Por fim, o grau e o alcance da participação social na política, seja através de sujeitos, indivíduos, movimentos ou atores sociais, define o direcionamento e a profundidade no estabelecimento de regimes de democratização parcial. 


\section{Referências Bibliográficas}

ABRANCHES, S. A. Os Despossuidos: crescimento e pobreza no país do milagre. Rio de Janeiro: Zahar, 1985.

BIRMAN, J. A interpretação e a singularidade do sujeito na experiência psicanalítica. Physis, 1(2):7-22, 1991.

BUSS, P. Saúde e Desigualdade: o caso do Brasil. Ensp/Fiocruz, 1994. (Mimeo.)

CAMPOS, G. W. de S. Os Médicos e a Política de Saúde, entre a Estatização e o Empresariamento: a defesa da prática liberal da medicina, 1986. Dissertação de Mestrado, São Paulo: Universidade de São Paulo.

CAMPOS, G. W. de S. Um balanço do processo de municipalização dos serviços de saúde do Brasil. Saúde em Debate, 28:24-27, 1990.

CAMPOS, G. W. de S. A Saúde Pública e a Defesa da Vida. Campinas: Hucitec, 1993.

CARDOSO, F. H. Autoritarismo e Democratização. Rio de Janeiro: Paz e Terra, 1975.

CASTRO, M. H. G. Interesses, organizações e políticas sociais. Caderno de Pesquisa, 14, 1989.

CARVALHO, A. I. et al. Os caminhos da descentralização no setor saúde brasileiro. Saúde em Debate, 38:49-54, 1993.

CARO, G. La Medicine en Question: critique de ia medicine dans le systeme capitaliste. Paris: Maspero, 1969.

COHN, A.; ELIAS, P. \& JACOBI, P. Participação popular e gestão de serviços de saúde: um olhar sobre a experiência do município de São Paulo. Saúde em Debate, 38:90-93, 1993.

DAHL, R. A. Procedural Democracy. Oxford: Laslett and Fishkin, 1979.

DAMASO, R. Justiça Social e Cidadania da Saúde. In: II Seminário Latino-Americano de Política Sanitária. México, mar. 1993.

DELLEUZE, G. Conversações. Rio de Janeiro: Editora 34, 1992.

DINIZ, E. Empresariado, Estado e Capitalismo no Brasil: 1930-1945. Rio de Janeiro: Paz e Terra, 1978.

DOIMO, A. M. \& BANK, G. A. Novas forças, velhos limites? Estudo de caso de um movimento social urbano. Serviç Social e Sociedade, 2:15-42, 1989. 
ELSTER, J. Nuts and Bolts for the Social Sciences. Cambridge: Cambridge University Press, 1989.

ESCOREL, S. Reforma Sanitária: um processo de reforma democrática do Estado brasileiro. Brasília, 1992. (Mimeo.)

FREUD, S. Civilization and its Discontents. London: The Hogar LTD, 1957.

GERSCHMAN, S. \& VIANNA, W. M. L. A Miragem da Pós-Modernidade: democracia e politicas sociais no contexto da democratização. Rio de Janeiro: Ed. Fiocruz, 1997. [2003]

HABERMAS, J. Mudança Estrutural da Esfera Pública. Rio de Janeiro: Tempo Universitário, 1984.

HIRSCH, J. Observações teóricas sobre o Estado burguês e sua crise. ln: POULANTZAS, N. (Org.) O Estado em Crise. Rio de Janeiro: Graal, 1977.

JACOBI, P. Movimentos Sociais e Políticas Públicas. São Paulo: Cortez, 1989.

KING, D. S. O Estado e as estruturas sociais de bem-estar em democracias industriais avançadas. Novos estudos Cebrap, 22, 1988.

LANGE, P. \& REGINI, M. Stato e Regolazione Sociale. Bologna: II Mulino, 1987.

MACPHERSON, C. B. A Teoria do Individualismo Possessivo: de Hobbes a Locke. Rio de Janeiro: Paz e Terra, 1979.

MAIER, C. Democracy and its descontents. Foreign Affairs, 73(4), 1994.

MAINWARING, S. Os movimentos populares de base e a luta pela democracia: Nova Iguaçu. In: STEPAN, A. et al. (Orgs.) Democratizando o Brasil. Rio de Janeiro: Paz e Terra, 1988.

MARSHALL, T. H. Cidadania, Classe Sociale Status. Rio de Janeiro: Zahar, 1967.

MOISES, J. A. Contradições Urbanas e Movimentos Sociais. Rio de Janeiro: Cedec/Paz e Terra, 1977.

MOUFFE, C. (Org.) Democratic citizenship and the political community. In: Dimensions of Radical Democracy. London/New York: Verso, 1992.

MULLER, N. J. S. Politicas de Saúde no Brasil: a descentralização e seus atores. In: IX Conferência Nacional de Saúde. Anais. Brasília, Ministério da Saúde, 1992.

NUNES, E. \& JACOBI, P. Movimentos Populares Urbanos, Participação e Democracia. Rio de Janeiro: Anpocs, 1980. (Mimeo.)

O’DONNELL, G. Reflexiones Sobre las Tendencias Generales de Cambio en el Estado Burocrático Autoritario. Buenos Aires: Cedes/Clacso, Documento n.1, 1975.

O’DONNELL, G. Transição, continuidade e alguns paradoxos. In: O’DONNEL, G. \& REIS, F. W. (Orgs.) A Democracia no Brasil: dilemas e perspectivas. São Paulo: Vértice, 1988.

OFFE, C. A atribuição de status público aos grupos de interesse. In: Capitalismo Desorganizado. São Paulo: Brasiliense, 1989.

OFFE, C. Problemas Estruturais do Estado Capitalista. Rio de Janeiro: Tempo Brasileiro, 1984.

OLIVEIRA, J. \& FLEURY, S. M. T. (Im)Previdência da Previdência Social: 60 anos da história da Previdência no Brasil. Rio de Janeiro: Vozes, 1986. 
OLSON, M. The Logic of Collective Action. Cambridge: Harvard University Press, 1965.

OSZLAK, O. \& O’DONNELL G. Estado y Política Estatal en America Latina: hacia una Estrategia de Investigación. Buenos Aires: Cedes/Clacso, Documento n.4, 1976.

PIERSON, P. Dismantling the Welfare State? Reagan, Thatcher, and the politics of retrenchment. Cambridge: Cambridge University Press, 1994. [1996, 1997]

POULANTZAS, N. O Estado, o Poder e o Socialismo. Rio de Janeiro: Graal, 1980.

PRZEWORSKI, A. Democracy and the Market: political and economic reforms in Eastern Europe and Latin America. Cambridge: Cambridge University Press, 1992.

RAWLS, J. A Theory of Justice. Cambridge: Harvard University Press, 1978.

SANTOS, W. G. dos. Cidadania e Justiça: a politica social na ordem brasileira. Rio de Janeiro: Campus, 1979.

SANTOS, W. G. dos. A lógica dual da ação coletiva. Revista de Ciências Sociais, 32(1):23-39, 1989.

SCHMIT'TER, P. C. The consolidation of political democracies process, rbytms, sequences, and types. California: Stanford University and Center for Advanced Studies in the Behavioral Sciences, 1991a. (Mimeo.)

SCHMITTER, P. C. The consolidation of democracy and the choice of institutions. California: Stanford University, 1991b. (Mimeo.)

SCHMITTER, P. C. The consolidation of democracy and representation of social groups. American Behavioral Science, 35(45):422-449, 1992a.

SCHMITTER, P. C. A donde ha ido la teoria del neocorporativismo y hacia donde puede ir su práctica. In: SCHMITTER, P. C.; STREEK, W. \& LEHNBRUCH, G. (Coords.) Neocorporativismo II: mas allá del Estado y del mercado. México: Editorial Patri, 1992b.

SCHMITTER, P. C. \& KARL, T. L. What democracy is and is not. Journal of Democracy, 2(30):75-88, 1991.

STREEK, W. \& SCHMIT'TER, P. C. Comunidad, mercado y asociaciones? La contribución prospectiva del gobierno de interés al orden social. In: SCHMITTER, P. C.; STREEK, W. \& LEHNBRUCH, G. (Coords.) Neocorporativismo II: mas allá del Estado y del mercado. México: Editorial Patri, 1992.

TEIXEIRA, S. M. F. Reflexões teóricas sobre democracia e reforma sanitária. In: . $A$ Reforma Sanitária: em busca de uma teoria. São Paulo: Cortez, 1989.

TOURAINE, A. Palavra e Sangue: política e sociedade na América Latina. Campinas: Trajetória/ Unicamp, 1989.

VIANNA, W. M. L. A Americanização (Perversa) da Seguridade Social no Brasil: estratégias de bem-estar e políticas públicas. Rio de Janeiro: Revan, 1998.

\section{Bibliografia}

ABRANCHES, S. A.; SANTOS, W. G. \& COIMBRA, M. A. Política Social e Combate à Pobreza. Rio de Janeiro: Zahar, 1987.

ARBLASTER, A. The Rise \& Decline of Western Liberalism. New York: Basil Blackwell, 1987. 
ARENDT, H. A Condição Humana. Rio de Janeiro: Forense Universitária, 1993.

CAMPOS, G. W. de S. A gestão enquanto componente estratégico para a implantação de um sistema público de saúde. In: IX Conferência Nacional de Saúde. Anais. Brasília, Ministério da Saúde, 1992a.

CAMPOS, G. W. de S. Reflexões sobre a proposta de gestão do sistema nacional de saúde. In: IX Conferência Nacional de Saúde. Anais. Brasília, Ministério da Saúde, 1992b.

CARDOSO, R. L. C. Popular Movements in the Context of the Consolidation of Democracy. Kellog Institute, working paper, 1989.

CONJUNTURA E SAÚDE. Rio de Janeiro, Ensp/Nupes/Fiocruz,1992/1993/1994.

DONANGELO, M. C. F. Medicina e Sociedade: o médico e seu mercado de trabalho. São Paulo: Livraria Pioneira, 1984.

DURHAM, E. Movimentos sociais: a construção da cidadania. Novos Estudos, 10:24-30, 1984.

ELSTER, J. Making Sense of Marx. Cambridge: Cambridge University Press, 1985.

ESPING-ANDERSEN, G. The Three Worlds of Welfare Capitalism. New Jersey: Princeton University Press, 1991.

EVERS, T. M.; PLANTENBERG, C. \& SPESSART, S. Movimentos de bairro e Estado: luta na esfera da reprodução na América Latina. In: MOISES, J. A. (Org.) Cidade, Povo e Poder. São Paulo: Cedec/Paz e Terra, 1982.

FIGUEIREDO, A. C. Democracia on Reformas? Alternativas Democráticas à Crise Política: 1961-1964. Rio de Janeiro: Paz e Terra, 1993.

FlORI, J. L. Democracia e reformas: equívocos, obstáculos e disjuntivas. In: IX Conferência Nacional de Saúde. Anais. Brasília, Ministério da Saúde, 1992.

FOUCAULT, M. Uso dos Prazeres - História da Sexualidade. Rio de Janeiro: Graal, 1984. v.2.

GERSCHMAN, S. Sobre a formulação de políticas sociais. In: FLEURY, S. (Org.) Reforma Sanitária em Busca de uma Teoria. São Paulo: Cortez, 1991.

GERSCHMAN, S. Movimientos sociales en salud: en busca de Ia reconstitución de lo social. In: FLEURY, S. (Org.) Estado y Politicas Sociales en America Latina. México/Rio de Janeiro: UAM - Xochimilco/Fiocruz, 1992.

GERSCHMAN, S. Las entidades médicas y el proceso de formulación e implementación de las políticas de salud en Brasil. Cuadernos Medico Sociales, 61:7-19, 1992.

GERSCHMAN, S. Movimentos sociais em saúde, formulação de políticas e construção de hegemonia. Nupes/Ensp/Fiocruz, 1992. (Relatório de Pesquisa).

GUIDDENS, A. Modern and Self: identity, self and society in the Late Modern Age. California: Stanford University Press, 1991.

HEIMANN, L. \& CARVALHEIRO, J. O Município e a Saúde. São Paulo: Hucitec, 1992.

IBAM, IMS/UERJ, NESC/CE, NESC/CPq, AM/FIOCRUZ-PE, NESCO/PR, NESCON/UFMG, NESS/BA. Avaliação do funcionamento dos Conselhos Estaduais e Municipais de Saúde. Brasília, ago. 1993. (Relatório Nacional, versão preliminar). 
JACOBI, P. Descentralização municipal e participação dos cidadãos. Apontamentos para o debate. In: IX Conferência Nacional de Saúde. Anais. Brasília, Ministério da Saúde, 1992.

LABRA, M. E. O sanitarismo desenvolvimentista. In: TEIXEIRA, S. M. F. (Org.) Antecedentes da Reforma Sanitária. Rio de Janeiro: Ensp/Fiocruz, 1988. (Textos de Apoio)

LACLAU, E. Os novos movimentos sociais e a pluralidade do social. Revista Brasileira de Ciências Políticas, 1(2):44-47, 1986.

LAMOUNIER, B. \& FIGUEIREDO, F. M. A Crise e a Transição para a Democracia no Brasil: dois estudos. São Paulo: Idesp, 1984. (Mimeo.)

LANDI, O. Crisis y lenguajes políticos. Estudios Cedes, 4(4), 1981.

LUZ, M. T. As Instituições Médicas no Brasil: instituições e estratégias de hegemonia. 2.ed. Rio de Janeiro: Graal, 1972.

MAINWARING, S. \& VIOLA, E. New social movements, political culture and democracy: Brazil and Argentine in the 1980s. Telos, 61:7-52, 1984.

MARX, K. Salário, Preço e Lucro. In: Karl Marx. São Paulo: Abril Cultural, 1978. (Coleção Os Pensadores)

MARX, K. A Crítica da Economia Política. In: Karl Marx. São Paulo: Abril Cultural, 1978. (Coleção Os Pensadores)

MEDICI, A. Estrutura e dinâmica da força de trabalho médica no Brasil na década de 70. In: __. Textos de Apoio. Planejamento I - 'Recursos Humanos em Saúde'. Rio de Janeiro: Pec/Ensp/Abrasco, 1987.

MELLUCI, A. Um objeto para os movimentos sociais? Lua Nova, 17:49-66, 1989.

MENDES, V. E. O Sistema Ùnico de Saúde e o Papel das Secretarias Estaduais de Saúde. In: IX Conferência Nacional de Saúde. Anais. Brasília, Ministério da Saúde, 1992.

MOISES, J. A. O Estado, as contradições urbanas e os movimentos sociais. In:

Classes Populares e Protesto Urbano, 1978. Tese de Doutorado, São Paulo: Universidade de São Paulo.

MOISES, J. A. Democracia e Crise Econômica: o paradoxo da América Latina. In:

(Org.) O Futuro do Brasil: a América Latina e o fim da Guerra Fria. Rio de Janeiro: Paz e Terra, 1992.

MUNCK, G. Social movements and democracy in Latin America, theoretical bates and comparative perspectives. In: XVI International Congress of the Latin American Studies Association. Washington, D.C., 1991.

ORTIZ, R. (Org.) \& FERNANDES, F. (Coord.). Pierre Bourdieu - Sociologia. São Paulo: Ática, 1983.

PIZZORNO, A. Algum tipo de diferença: uma crítica das teorias da 'escolha racional'. In: FOXLEY A.; MAC PHERSON, M. \& O’DONNELL, G. (Orgs.) Desenvolvimento e Política e Aspirações Sociais: o pensamento de Albert O. Hirschman. São Paulo: Vértice, 1988.

PRZEWORSKI, A. A social democracia como fenômeno histórico. Lua Nova, (4) 5:41$81,1988$. 
REGINI, M. Las cambiantes relaciones entre el trabajo y el Estado en Italia: hacia un sistema neocorporativista? In: SCHMITTER, P. (Org.) Neocorporativismo II. México: Alianza Editorial, 1992.

SANTOS, N. R. dos. Governabilidade na saúde. Saúde em Debate, 34:4-12, 1992.

SANTOS, W. G. dos. Razões da Desordem. Rio de Janeiro: Rocco, 1993.

SCHMITTER, P. C. Neocorporativismo y Estado. Revista Española de Investigaciones Sociológicas, 31:47-78, 1985.

SCHRAIBER, L. B. Medicina Liberal e Incorporação de Tecnologia: as transformações históricas da autonomia profissional dos médicos em São Paulo, 1988. Tese de Doutorado, São Paulo: Universidade de São Paulo.

SCHRAIBER, L. B. O Médico e seu Trabalho: limites da liberdade. São Paulo: Hucitec, 1993. 229p. (Série Saúde em Debate, 61)

TEIXEIRA, S. M. F. Descentralização dos serviços de saúde: dimensões analíticas. RAP, 24:78-100, 1990.

UGÁ, A. D. Ajuste e política social: a experiência latino-americana. Archetypon, 5:87-112, 1994.

UNIVERSIDADE DE CAMPINAS (UNICAMP), Núcleo de Estudos de Políticas Públicas. O Sistema de Proteção Social no Brasil. Projeto: Social Policies for the Urban Poor in Southern Latin America. São Paulo, 1991. (Mimeo.)

VIANNA, M. L. W. (Coord.). O Inamps enquanto Organização e suas Clientelas. Rio de Janeiro, IEI/UFRJ, 1987. (Relatório de Pesquisa)

WALZER, M. Spheres of Justice: a defense of pluralism and equality. New York: Basic Books Inc. Publishers, 1983.

WEBER, M. Ensayos sobre Metodología Sociológica. Buenos Aires: Amorrortu, 1958.

WEBER, M. Basic Concepts in Sociology. London: Peter Owen London Lin, 1978. 
Formato: 16 x $23 \mathrm{~cm}$

\section{Tipologia: Aucoin Light e Garamond}

Papel: Pólen Bold $70 \mathrm{~g} / \mathrm{m}^{2}$ (miolo)

Cartão Supremo $250 \mathrm{~g} / \mathrm{m}^{2}$ (capa)

Reimpressão e acabamento: Imprinta Gráfica e Editora Ltda.

Rio de Janeiro, julho de 2011

Não encontrando nossos títulos em livrarias, contactar a EDITORA FIOCRUZ:

Av. Brasil, 4036 - Térreo, s. 112, Manguinhos - 21041-361 - Rio de Janeiro - RJ

Tel.: (21) 3882-9039 e 3882-9041 - Telefax: (21) 3882-9006

http://www.fiocruz.br/editora

e-mail: editora@fiocruz.br 